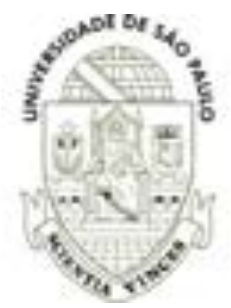

UNIVERSIDADE DE SÃO PAULO

PROGRAMA DE PÓS-GRADUAÇÃO INTERUNIDADES DE ESTÉTICA E HISTÓRIA DA ARTE

Ana Paula Cattai Pismel

Schenberg: em busca de um Novo Humanismo

São Paulo 
ana Paula Cattai Pismel

\section{Schenberg: em busca de um Novo Humanismo}

Dissertação apresentada ao Programa Interunidades de Pós-Graduação em Estética e História da Arte (PGHEA/USP) para obtenção do título de Mestre em Estética e História da Arte.

Orientadora: Prof. ${ }^{a}$ Dr. ${ }^{a}$ Elza Ajzenberg. Linha de pesquisa: Teoria e Crítica de Arte.

São Paulo 
AUTORIZO A REPRODUÇÃO E DIVULGAÇÃO TOTAL E PARCIAL DESTE TRABALHO, POR QUALQUER MEIO CONVENCIONAL OU ELETRÔNICO, PARA FINS DE ESTUDO E PESQUISA, DESDE QUE CITADA A FONTE.

Catalogação da Publicação

Biblioteca Lourival Gomes Machado

Museu de Arte Contemporânea da Universidade de São Paulo

Pismel, Ana Paula Cattai.

Schenberg : em busca de um Novo Humanismo / Ana Paula Cattai Pismel ; orientadora Elza Ajzenberg. -- São Paulo, 2013.

193 f. : il.

Dissertação (Mestrado - Programa de Pós-Graduação Interunidades em Estética e História da Arte) -- Universidade de São Paulo, 2013.

1. Avant-Garde - Brasil - Décadas de 1960 e 1970. 2. Novo Realismo. 3. Humanismo. 4. Bienais de Arte - Brasil - Décadas de 1960 e 1970. 5. Schenberg, Mário, 1914-1990. I. Ajzenberg, Elza. II. Título.

CDD 709.81 
Nome: PISMEL, Ana Paula Cattai.

Título: Schenberg: em busca de um Novo Humanismo.

Aprovado em:

Dissertação apresentada ao Programa Interunidades de Pós-Graduação em Estética e História da Arte (PGHEA/USP) para obtenção do título de Mestre em Estética e História da Arte.

Orientadora: Prof. ${ }^{a}$ Dr. ${ }^{a}$ Elza Ajzenberg.

Linha de pesquisa: Teoria e Crítica de Arte.

\section{Banca Examinadora}

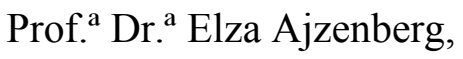

Julgamento:

Prof. ${ }^{\text {a }}$ Dr. ${ }^{\text {a }}$ Carmen Aranha

Julgamento:

Prof. ${ }^{a}$ Dr. ${ }^{a}$ Alecsandra Matias de Oliveira

Julgamento:
Universidade de São Paulo

Assinatura:

Universidade de São Paulo

Assinatura:

Universidade de São Paulo

Assinatura: 
À minha família

Aos que nada fazem sem alegria ${ }^{1}$

${ }^{1}$ Referência à frase do filósofo Michel de Mongaigne, Je ne fais rien sans gayeté (Não faço nada sem alegria), retirada da obra Des Livres, que foi tomada por José Mindlin como lema. Estampada na entrada da recéminaugurada Biblioteca José e Guita Mindlin, essa frase foi um grande incentivo no decorrer da elaboração desta dissertação, na medida em que, apesar das dificuldades inerentes à pesquisa, também ela foi feita com grande alegria. 


\section{Agradecimentos}

Aos brasileiros, que por meio da CAPES possibilitaram a realização desta pesquisa.

À Universidade de São Paulo, pelo ambiente universitário amplo e repleto de possibilidades de aprendizado, o qual pude viver intensamente enquanto estudante desde a graduação.

Ao Programa Interunidades de Estética e História da Arte - USP, seu corpo docente e administrativo, pelo suporte oferecido. Aos colegas, pelo apoio mútuo em meio às alegrias e expectativas inerentes à pesquisa e à pós-graduação.

À Prof. ${ }^{a}$ Dr. ${ }^{a}$ Elza Ajzenberg, orientadora desta dissertação, pela paciência e generosidade incomuns, pelos ensinamentos e pelo exemplo de seriedade e excelência acadêmica.

À Prof. ${ }^{a}$ Dr. ${ }^{a}$ Alecsandra Matias de Oliveira, que sempre esteve pronta a me ouvir, esclarecer minhas dúvidas e me aconselhar nesse percurso. Pela competência e desprendimento, agradeço imensamente.

À Prof. ${ }^{a}$ Dr. $^{\text {a }}$ Carmen Aranha, pela atenção e disponibilidade ímpares e pelos conselhos tão relevantes para o andamento desta pesquisa. Ao Prof.. Dr. Francisco Alembert e à Polyana Canhête, sou imensamente grata pela simpatia, pelo apoio e, claro, pelas preciosas pistas com relação às Bienais de São Paulo.

Ao Centro Mario Schenberg de Documentação da Pesquisa em Artes - ECA/USP e equipe, sem os quais este trabalho não teria sido possível.

Ao Arquivo Histórico Wanda Svevo da Fundação Bienal, em especial à pesquisadora Ana Paula Marques, pela preciosa assessoria.

Ao Arquivo do Instituto de Estudos Brasileiros e seus bibliotecários que, com grande atenção, auxiliaram o de levantamento de parte das fontes primárias utilizadas nesta pesquisa.

À minha família: Maria José e José Jarbas, amados pais, pelos momentos de plenitude e apoio incondicional, pela presença reconfortante e pela compreensão das ausências; a Adriana e Ana Cláudia, queridas irmãs, pelas conversas, conselhos, companhia. A todos vocês, minha eterna gratidão. 
Àquele que, com serenidade e carinho imensos, soube comemorar pequenas conquistas e compreender grandes ansiedades. Paulo, obrigada por ser quem é e estar a meu lado.

Aos amigos que, próximos ou distantes, fizeram parte dessa caminhada, especialmente Amanda de Paula Costa Santos e Grasiele Pereira Jannuzzi, pela convivência diária, pelas risadas e conversas sobre amenidades que fizeram um bem enorme nos momentos de cansaço.

Não tão próximos fisicamente, mas não menos importantes, são os amigos cuja presença é sentida apesar da distância. São eles, Juliana Braz Ferire, Juliana Isquerdo, Manuela Petschilies, Nathália Fidêncio e Bruno Araújo. A vocês, meus agradecimentos pela compreensão das ausências e pelo ânimo transmitido nos contatos limitados pelo espaço e tempo que se interpõem às nossas caminhadas individuais após o Ensino Médio e a Graduação. 


\section{Título}

Schenberg: em busca de um Novo Humanismo

\section{Resumo}

Este estudo objetivou evidenciar a visão de Novo Realismo de Mario Schenberg, dada sua importância no horizonte das Vanguardas Brasileiras das décadas de 1960 e 1970, bem como sua relação com o Novo Humanismo, também desenvolvido pelo crítico de arte durante esse período. Foi analisado o envolvimento de Schenberg no debate das décadas de 1960 e 1970 , tendo por base sua atuação nas exposições Opinião 65, Propostas 65, Opinião 66, Propostas 66, bem como nas Bienais de São Paulo (1961, 1965, 1967, 1969 e 1971). O estudo tomou por fontes primárias as críticas originais do Centro Mario Schenberg de Documentação da Pesquisa em Arte - ECA/USP escritas nas nessas duas décadas, bem como os demais livros, artigos e entrevistas do crítico. Considerado por Mario Schenberg a expressão artística do Novo Humanismo, o Novo Realismo foi definido a partir de um horizonte paralelo: fruto da sociedade industrial e reflexo da cultura ocidental em crise, essa tendência refletiu um momento de ampliação de referenciais. Mario Schenberg soube compreender as demandas da arte nascente, na medida em que sua atividade crítica não se deu como julgamento e avaliação, mas como compreensão e incentivo.

Patavras-chave: Mario Schenberg, Novo Realismo, Novo Humanismo, Vanguardas Brasileiras 


\title{
Title
}

Schenberg: In search of a New Humanism

\begin{abstract}
This Study had the objective of showing the vision of the New Humanism of Mario Schenberg, due to its importance in the horizon of the Brazilian Vanguards from the 1960's and 1970's decades, as well as its relation to the New Humanism, also developed by the art critic during this period. The involvement of Schenberg in the debate of the 1960's and 1970's decades was analyzed, based on his actuation on the expositions Opinião 65, Propostas 65, Opinião 66, Propostas 66, as well as in the São Paulo Biennials (1961, 1965, 1967, 1969 e 1971). This study considered by primary sources the original critics of the Centro Mario Schenberg de Documentação da Pesquisa em Arte - ECA/USP written in these two decades, as well as the rest of the books, articles and interviews of the critic. Considered by Mario Schenberg the artistic expression of the New Humanism, the New Realism was defined from a parallel horizon: result of an industrial society and a reflex of an occidental culture in crisis, this tendency reflected in a moment of referential amplifications. Mario Schenberg knew how to comprehend the demands of the rising art, in which, his critical activities were not made by judgment and evaluation, but as comprehension and incentive.
\end{abstract}

Key-words: Mario Schenberg, New Realism, New Humanism, Brazilian Vanguards 


\section{Lista de Imagens}

FIGURA 2 - ALFREDO VOLPI, [COMPOSIÇÃO COM FAIXAS], DÉC. 1960, TÊMPERA SOBRE TELA, 75 X 110,3 CM. COLEÇÃo PARTICUlar. REPRODUÇÃO FOTOGRÁFICA HORST MERKEL.

FIGURA 1 - AlFREdO VOLPI, [VISTA DE ITANHAÉM] [MARINHA DE ITANHAÉM], DÉCADA DE 1940, TÊMPERA SOBRE TELA, 45 X 76 CM. COLEÇÃO PARTICULAR. REPRODUÇÃO FOTOGRÁFICA DE AUTORIA DESCONHECIDA.........25

FIGURA 3 - AlFREdO VOLPI, FACHADA COM BANDEIRAS, 1959, TÊMPERA SOBRE TELA, 116 X 72 CM. ACERVO DO Museu de ARTE de SÃo PaUlo - MASP, DOAÇ̃̃o de ERnEST WOLF.

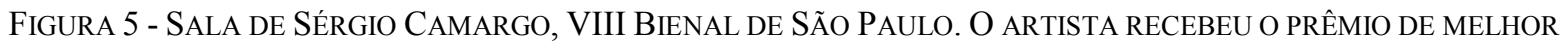
ESCULTOR NACIONAL NA EDIÇÃO.

FigURA 4 - MARIA BONOMI, 1965, XILOGRAVURA SOBRE PAPEL DE ARROZ, 130 X 108. A ARTISTA GANHOU O PRÊMIO DE MELHOR GRAVADORA NACIONAL.

FIGURA 7 - JASPER JOHNS, TRESS BANDEIRAS, 1958.

Figura 6 - QuisSAK JÚNIOR, POLÍPTICO MÓVEL UM OU DO CAMPO VERDE, POLÍPTICO MÓVEL DOIS OU DO Losango amarelo, Políptico Móvel três ou do Círculo AZul, Políptico Móvel Quatro ou da FaIXa BRANCA, POLÍPTICO MÓVEL CINCO OU DA PÁTRIA. 1967, ÓlEO SOBRE TELA.

Figura 8 - HÉlio OiticiCA, B15 BÓlIDE VIDRO 4 - TERRA, 1964, CUBA DE VIDRO, TERRA E TECIDO. PROJETO HELIO OITICICA (RIO DE JANEIRO, RJ). REPRODUÇÃO FOTOGRÁFICA AUTORIA DESCONHECIDA.

FIGURA 9 - MiRA SCHENDEL, ONDAS PARADAS DE PROBABILIDADE, 1969 (RECRIADA EM 2009), INSTALAÇÃO, DIMENSÕES VARIÁVEIS. FIOS DE NÁILON E TEXTO EM PLACA DE ACRÍTICO AFIXADO NA PAREDE. COLEÇÃO ADA SCHENDEL.

FIGURA 10 - X BIENAL DE SÃo PAULO, EM 1969. EM PRIMEIRO PLANO, ESTRUTURAS TEMPORÁRIAS, EM FORMA DE OCA, CONSTRUÍDAS PARA ABRIGAR OS EVENTOS DA II BIENAL DE CIÊNCIA E HUMANISMO. 63

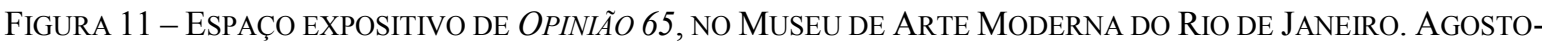
SETEMBRO DE 1965.

FIGURA 12 - CONVITE ORIGINAL DA EXPOSIÇÃO OPINIÃO $65 .$.

FigurA 13 - RUBENS GERCHMAN, CONCURSO DE MISS, 1965, ACRÍLICA SOBRE TELA, 140 X 280 CM. COLEÇÃO GILBERTO CHATEAUBRIAND - MAM-RJ. REPRODUÇÃO FOTOGRÁFICA AUTORIA DESCONHECIDA................68

FIGURA 14 - WALDEMAR CORDEIRO, AMARGO, 1965, TECIDO E LÂMPADA, 20.5 X 28.3 X 3.9............................75

FigURA 15 - HÉlio OITICICA, TROPICÁLIA , 1967. PlANTAS, AREIA, PEDRAS, ARARAS, APARELHO DE TELEVISÃO,

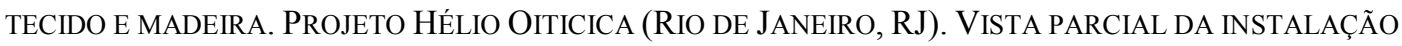
TROPICÁlia - PB2 (IMAGÉTICO) E PN3 (A PuREZA É uM Mito) - MOSTRA NOVA OBJETIVIDAdE BRASILEIRA, REALIZADA NO MAM-RJ, EM 1967. REPRODUÇÃO FOTOGRÁFICA CÉSAR OITICICA FILHO...... 96

Figura 16 - MAURício NOGUEIRA LiMA, NÃO ENTRE À ESQUERDA, 1964, METAL E ESMALTE SinTÉTICO SOBRE AGLOMERAdo, ACERVO MUSEU DE ARTE MODERNA -SP. 101

Figura 17 -Maurício Nogueira Lima, NO AR, No WAR, 1966. COlaGEM, GUACHE E TÊMPERA SOBRE CARTÃO, $40 \times 51 \mathrm{CM}$. 102

Figura 18 - MaUrício Nogueira Lima, "TCHAF" POSITIVO, 1967. ACRÍliCA SOBRe CARTÃo, 80 X 80 CM. COL. PARTICULAR.

FigURA 19 -MAURICIO NOGUEIRA LIMA, MARILYN MONROE, 1969. SERIGRAFIA, 73 X 73 CM. ...........................104

Figura 20 -José RoBerto Aguilar, IMAGEM (DíPTICO) , 1967. ACRÍLICA SOBRE TELA, 114 X 292 CM. REPRODUÇÃO FOTOGRÁFICA ROMULO FIALDINI.

Figura 21 - José RoBerto Aguilar, SEM TÍTUlo, CA. 1965. ÓleO SOBRE TELA, C.I.D. 73 X 92 CM. REPRODUÇÃO FOTOGRÁFICA ROMULO FIALDINI.

Figura 22 -MÁRIO GRUBER, RETRATO DE MÁRIO SCHENBERG, 1978. ÓleO SOBRE TELA, C.I.D. 64 X 53 CM. Centro Mario Schenberg de DocumentaÇÃo da Pesquisa em Artes - ECA/USP. ReProduÇão FOTOGRÁFICA AUTORIA DESCONHECIDA. 
Figura 23 -MÁrio Gruber, FANTASIAdo II , 1976. Óleo e TINTA ACRÍliCA SOBRE TELA, C.I.D. 73,5 X 64 CM.

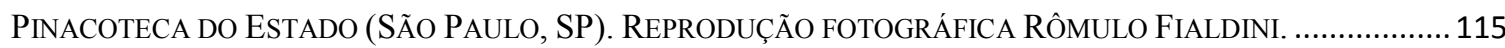

Figura 24 - WeSLEy DUKE LEE, O HELICÓPTERO, 1969, InSTALAÇÃO/POLIMATÉRICO, $\varnothing 400$ CM...................... 120 Figura 25 -Hélio Oiticica, RELEVO ESPACIAL, 1959. ACRílico SOBRe MadeIRA, 16 X 63 X 150 CM. Projeto Helio OItICICA (RIO DE JANEIRO, RJ). REPRODUÇão FOTOGRÁFICA ANTONIO CAETANO........................... 120

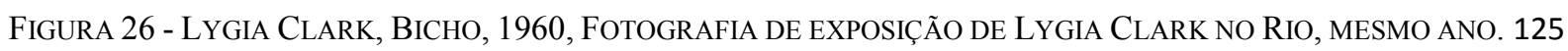
FigURA 27 - REGISTRO DA PERFORMANCE CAMINHANDO, FEITA POR LYGIA CLARK EM 1963, EM QUE A ARTISTA

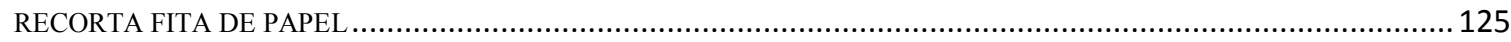

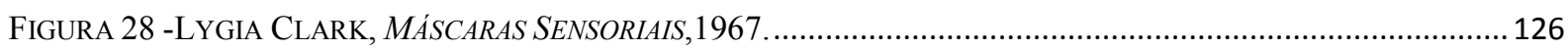

FigURA 29 - LyGIA CLARK, ARQUITETURAS BIOLÓGICAS: OVo-MoRTALHA, 1968........................................... 126

Figura 30 -José Roberto Aguilar, SÉrIe Do FUtebol II , 1966. SPRAY SOBRE TEla, 114 X 146 CM. ColeÇão

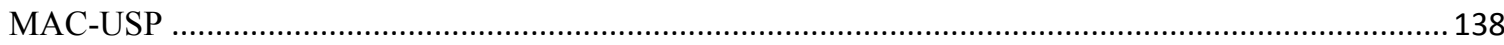

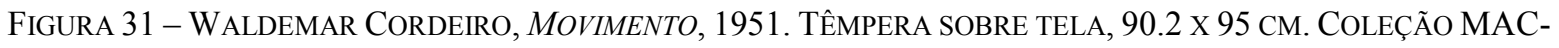
USP. .138

Figura 32 - WALDEMAR CORdEIRO, José LUIZ AgUiRRE / ESTEVAM ROBERTO SERAFIM, USP, A MULHER QUE

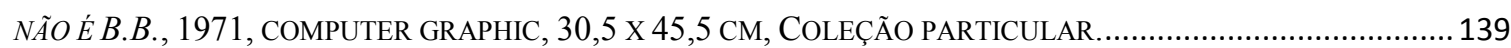

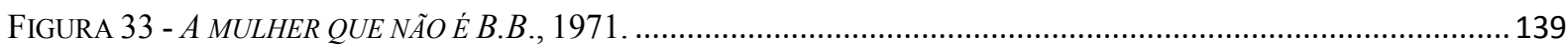

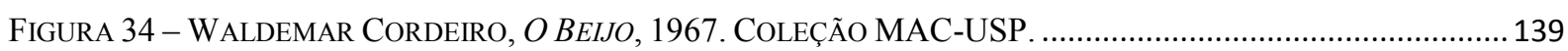

Figura 35 - Cartão Postal WesSEl. Fotografia do antigo Palacete SANTA Helena, DEMOLIdo em 1971, QUANDO DA CONSTRUÇÃO DA ESTAÇÃO DO METRÔ DA SÉ. ...........................................................................

Figura 36 -MANuel Martins, PRAÇA DA SÉ, Ca. 1940. Óleo SOBRe Madeira, C.S.E., 50 X 40 CM. ReProduÇão

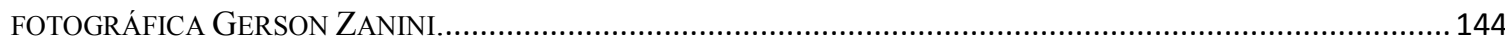

Figura 37 - Aldo BonAdeI, PAISAGEM , 1946. ÓleO SOBRE TELA, 50 X 63 CM. REPRODUÇÃO FOTOGRÁFICA

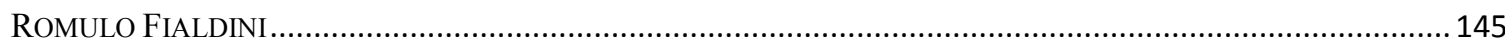

Figura 38 - Francisco Rebolo Gonsales. PaISAGEM Com FigURAS, 1942. Coleção MAC USP................... 145

FigURA 39 - MA YÜAN, PAISAGEM AO LUAR, C. 1200. ROLO SUSPENSO, PINTURA EM SEDA, 149, 7 X 78, 2 CM. MUSEU

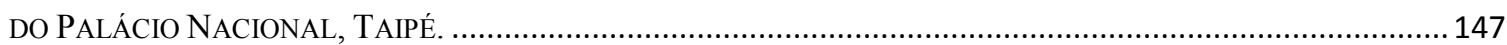

FIGURA 40 - MIRA SCHENDEL. MONOTIPIAS. ÓLEO SOBRE PAPEL DE ARROZ, 1965, 46 X 172 CM........................... 149

Figura 41 - Mira SCHENDEL, SEM título, 1964-65. MONOtiPia (ÓleO SOBRE PAPEL DE ARROZ), 46 X 23 CM. 150

Figura 42 - FlÁVIO de CARVALHO, RETRATO DE MÁRIO SCHEMBERG, 1968, ÓleO SOBRE TELA, C.S.D., 98 X 67 CM.

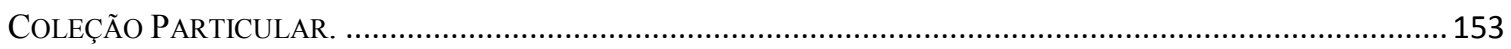

Figura 43 - Vi Bienal de SÃo Paulo. Reproduções de Quadros de Alfredo Volpi. Autoria

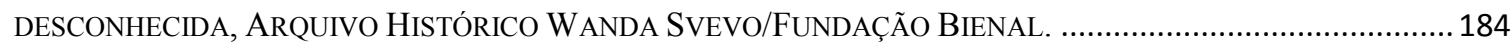

Figura 44 -Vi Bienal de São Paulo. Reproduções de Quadros de Alfredo VolPi. Autoria

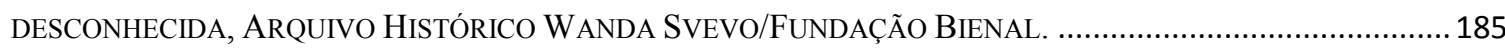

Figura 45 -Vista externa com outdoor da Vi Bienal de São Paulo. Autoria DesconheCida, Arquivo

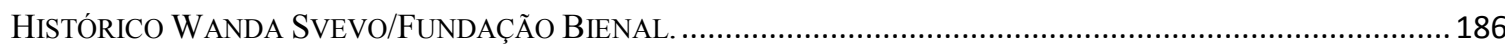

FigURA 46 -X BiENAL DE SÃo PAULO, VISTA EXTERNA.. ESTRUTURAS TEMPORÁRIAS, EM FORMA DE OCA, CONSTRUídAs PARA ABRIGAR OS EVENTOS DA II BIENAL DE CIÊNCIA E HUMANISMO. AUTORIA DESCONHECIDA, ARQUIVO HISTÓRICO WANDA SVEVO/FUNDAÇ̃̃o BIENAL. 


\section{Sumário}

INTRODUÇÃO

PORQUE OPINAR É PRECISO: SCHENBERG E SEU CONTEXTO.................................................20

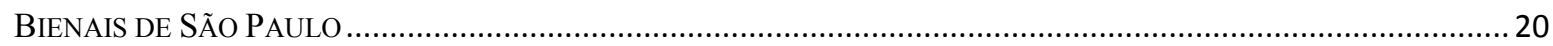

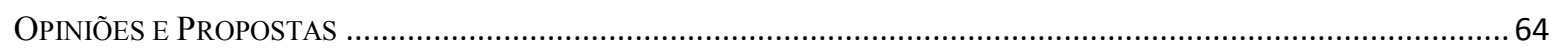

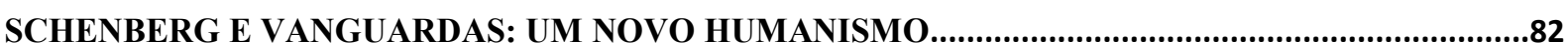

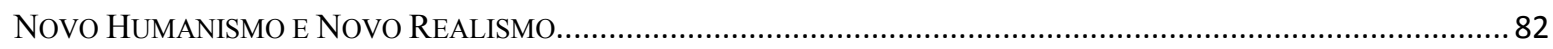

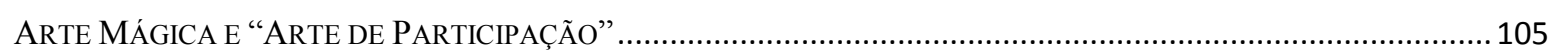

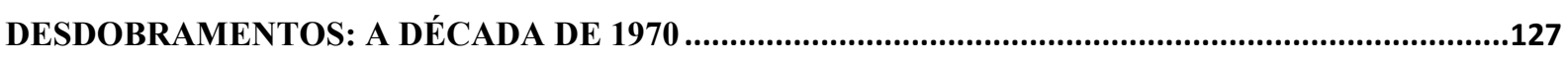

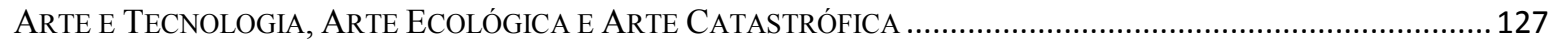

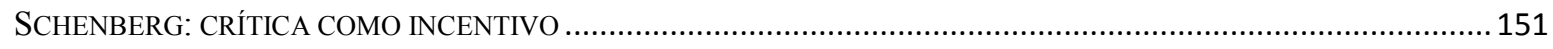

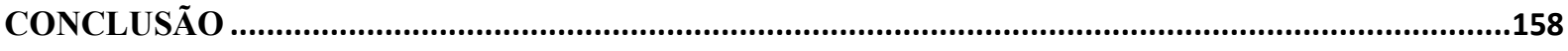

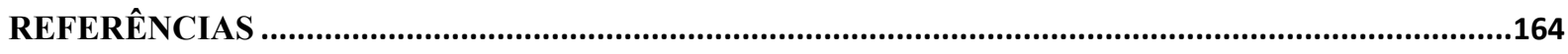

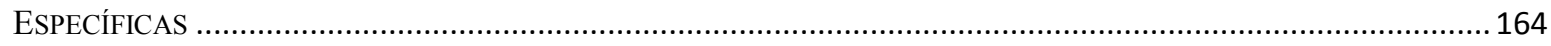

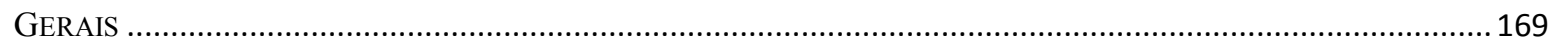

ANEXOS

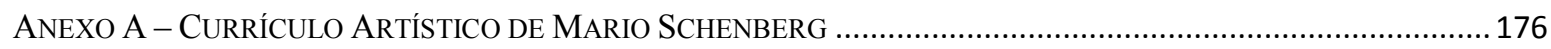

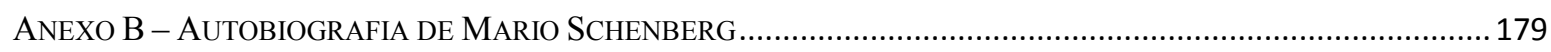

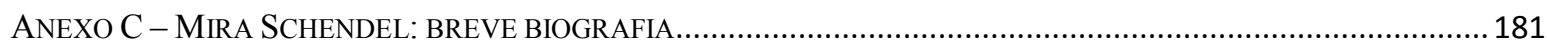

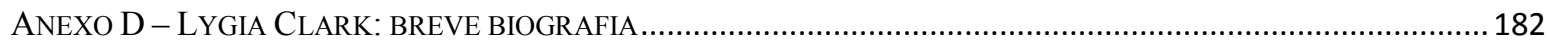

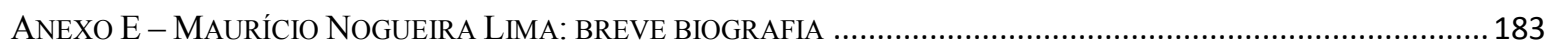

ANeXo F - Bienais de São PaUlo: IMAGens ARquivo Histórico Wanda SVEVo/ FundaÇão BiENAL.... 184

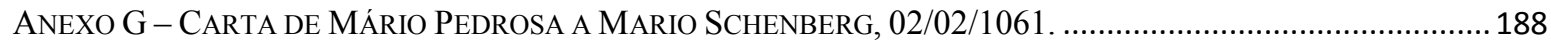

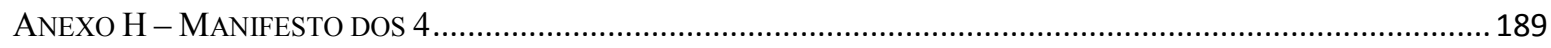

ANEXo I - CARTA DE MAURÍcio NOGUEIRA LIMA A FranCiSCO MATARAZZO SOBRINHO, 16/05/1969......... 190

ANEXo J - ATA DA PRIMEIRA REUNIÃo do JÚRI DE SELEÇÃo PARA A X BIENAL DE SÃo PAUlO, 27/05/1969.192

ANEXO K - HISTÓRICO DO CENTRO MARIO SCHENBERG - ECA/USP ........................................................ 193 


\section{Introdução}

Mario Schenberg (Recife/PE 1914 - São Paulo/SP 1990) foi uma personalidade marcante, de amplos horizontes, inteligência viva e intuição aguçada. Mais conhecido por seus trabalhos em física teórica e astrofísica, além do Processo Urca (desenvolvido juntamente com George Gamow na década de 1940) ${ }^{1}$, o físico teórico de renome internacional foi também crítico de arte e militante político.

O interesse pela arte, cultura e pelo ser humano fez de Schenberg uma personalidade muito querida e respeitada por artistas, intelectuais e críticos de arte principalmente entre as décadas de 1940 e 1980, período no qual se dedicou à crítica de arte, bem como a descobrir e incentivar novos artistas. O físico Alberto Luiz da Rocha Barros, antigo assistente de Schenberg, comentou que a ele se pode aplicar a frase de Terêncio, que Karl Marx citava: "Sou humano, e nada que é humano me é estranho"2. Não se pode esquecer que para Schenberg, em sua cosmovisão, arte, ciência e política não estavam separadas, mas em proximidade e consonância, visto que para o crítico não havia fronteiras entre elas.

O crítico tornou-se, nas décadas de 1960 e 1970, teórico do Novo Realismo e do Realismo Fantástico ${ }^{3}$ (cujo sentido será explicitado a seguir), tendo escrito muito sobre essas tendências. Por meio de seus textos, constatou-se que esteve presente nos debates a esse respeito e manteve proximidade com artistas cujas pesquisas tomaram essas direções. O artista Maurício Nogueira Lima apontou que o crítico deu muito apoio aos

\footnotetext{
${ }^{1}$ Alberto Luiz da Rocha Barros esclareceu que, no início de sua carreira, Schenberg trabalhou com Enrico Fermi na Universidade de Roma e com Wolfgang Pauli em Zurique. Esses dois cientistas introduziram na física o neutrino, uma partícula com carga elétrica e massa evanescente (BARROS Alberto Luis da Rocha. Schenberg: Nada do que é Humano lhe era Estranho. In Estudos Avançados, 11(5), 1991, p, 195). Na década de 1940, trabalhando com George Gamow nos Estados Unidos, Schenberg teve a intuição de introduzir o neutrino para explicar o colapso que inicia o processo explosivo em estrelas novas e supernovas, uma vez que os estudos dos quais Gamow partira tinham sido escritos antes de se ter ideia do neutrino. O que motivou o nome Processo Urca foi uma comparação feita por Gamow: este observou que as estrelas perdiam neutrinos assim como jogadores perdiam dinheiro no Cassino da Urca, famoso na época, que havia visitado com Schenberg ao conhecer o Rio de Janeiro. (SCHENBERG, Mario. Formação da Mentalidade Científica. In Estudos Avançados, 12(5), 1991, p. 140).

2 BARROS Alberto Luis da Rocha. Schenberg: Nada do que é Humano lhe era Estranho. In Estudos Avançados, 11(5), 1991.

${ }^{3}$ OLIVEIRA, Alecsandra Matias de. Schenberg: crítica e criação. São Paulo: Edusp, 2011, p.119.
} 
grupos de vanguarda nos anos de 1960, escrevendo sobre eles e refletindo acerca de suas características e intenções ${ }^{4}$.

A atuação de Mario Schenberg como crítico de arte foi o objeto desta pesquisa. Suas reflexões sobre o Novo Realismo, durante as décadas de 1960 e 1970, bem como sua concepção de um Novo Humanismo (termo que será definido adiante) constituíram as preocupações do estudo ora apresentado. Na visão de Schenberg, o Novo Humanismo estaria estritamente ligado aos desdobramentos do Novo Realismo no Brasil durante o período delimitado. Cabe, aqui, investigar essa relação, bem como seu desenvolvimento pelo crítico.

Mario Schenberg participou de momentos marcantes do cenário artístico da década de 1960, tais como as exposições Opinião 65 e Propostas $65^{5}$, bem como das Bienais Internacionais de Arte de São Paulo dos anos de 1965, 1967 e 1969, como membro do Júri Nacional de Seleção. Nesse ínterim, o crítico manteve contato com artistas como Lygia Clark, Hélio Oiticica, Mira Schendel, Maurício Nogueira Lima, José Roberto Aguilar, entre outros.

As observações sobre o desenvolvimento do Novo Realismo, do Realismo Fantástico e do Realismo Mágico continuaram presentes na crítica de arte de Schenberg na década de 1970, mas em menor medida. Suas considerações apontaram com mais frequência tendências como Arte Primitiva, Catastrófica e Ecológica (também definidas adiante), todas vistas por ele como desdobramentos do Novo Realismo.

Cabe observar que as Bienais de São Paulo foram eventos representativos das tendências das artes plásticas nesse ínterim, tanto pela presença, quanto pela ausência de artistas, críticos e intelectuais - como na edição de 1969, com o início do boicote

\footnotetext{
4 "Nessa época, a principal característica de Schenberg, foi a de apoiar os grupos de vanguarda que tentavam subverter a arte brasileira; principalmente na década de 60, quando eu e o Schenberg mais colaboramos com esses grupos. [...] Mário nos deu um grande apoio, escrevendo vários artigos; mas, infelizmente, não tinha acesso aos meios de comunicação (jornais, televisão etc). Os artigos eram publicados em catálogos de exposições e, às vezes, uma ou outra revista cedia espaço para ele expor o seu pensamento". (LIMA, Maurício Nogueira. Mário Schenberg: incentivador e crítico. In AJZENBERG, Elza (org.). Schenberg - Arte e Ciência. São Paulo, 1995, p. 42). Com relação às citações diretas neste estudo, optou-se por manter sempre a grafia original da fonte, conforme se verá adiante.

${ }^{5}$ Opinião 65 teve lugar no Museu de Arte Moderna do Rio de Janeiro, entre agosto e setembro de 1965. Foi organizada por Jean Boghici e Ceres Franco. A proposta da exposição era reunir artistas residentes em Paris e no Brasil, promovendo um confronto entre a produção daqueles e a dos jovens artistas de vanguarda no país. Ambos tinham proximidade com a nova figuração, a Pop Art e o Nouveau Réalisme. Pouco tempo depois, em São Paulo, foi inaugurada a exposição Propostas 65, no Museu de Arte Brasileira da Fundação Armando Álvares Penteado (MAB/FAAP), em dezembro, acompanhada de um seminário. A mostra paulista foi a repercussão imediata da exposição carioca e, reunindo muitos dos artistas participantes de Opinião 65. No ano seguinte, Opinião 66, também no MAM do Rio, abria entre agosto e setembro de 1966, por iniciativa dos mesmos organizadores. Em dezembro do mesmo ano, teve lugar o seminário Propostas 66, dessa vez na Biblioteca Pública Municipal Mário de Andrade.
} 
internacional. Nesse período, Mario Schenberg esteve próximo da organização desses eventos: para a edição de 1961, realizou a sala especial dedicada ao pintor Alfredo Volpi e nas edições de 1965, 1967 e 1969, foi membro do Júri Nacional de Seleção. Para essa função, o crítico foi eleito pelos $\operatorname{artistas}^{6}$, que confiavam em sua atuação e acreditavam que ele poderia defender seus interesses junto ao júri do evento ${ }^{7}$. Na edição de 1971, apesar de não ter integrado o corpo de jurados, participou de uma MesaRedonda Internacional de Críticos de Arte, que discutiu a crise da Bienal ${ }^{8}$.

O ano de 1965 significou a tomada de posição política e contestação, pondo fim ao breve silêncio por parte dos artistas desde o golpe de 1964, marcado por prisões arbitrárias, tortura e desaparecimentos. As exposições Opinião 65 (MAM-RJ) e Propostas 65 (MAB-FAAP) - e, no ano seguinte, Opinião 66 (MAM-RJ) e Propostas 66 (Biblioteca Municipal - SP) - promoveram mostras de arte, conferências e debates entre artistas e críticos que, tomando a palavra, demarcavam o caminho a ser seguido pela Vanguarda Brasileira até os anos de 1970. Essas exposições tiveram o mérito de proporcionar espaço para conceituações de vários artistas e críticos de arte a respeito das mudanças pelas quais passavam as artes plásticas naquele momento. Nesse contexto, a contribuição de Mario Schenberg foi das mais significativas, dado que sua formulação do Novo Realismo influenciou vários artistas, entre eles, os da Nova Objetividade Brasileira9 ${ }^{9}$

O contexto político da época, no qual está a Ditadura Militar que, após o golpe de 1964, passou a impor a Mario Schenberg perseguições e diversas restrições. Em nível internacional, a ameaça da guerra nuclear e da extinção da humanidade que

\footnotetext{
${ }^{6}$ AGUILAR, José Roberto. O mundo de Mario Schenberg. São Paulo: Casa das Rosas, 1996.

${ }^{7}$ OLIVEIRA, Alecsandra Matias de. Schenberg: crítica e criação. São Paulo: Edusp, 2011.

${ }^{8}$ Cf. Arquivo Wanda Svevo/Fundação Bienal e ALAMBERT, Alambert \& Polyana CANHÊTE. Bienais de São Paulo: da era do museu à era dos curadores. São Paulo: Boitempo, 2004.

${ }^{9}$ A discussão iniciada com Opinião 65 teve repercussão na formulação da Nova Objetividade Brasileira, vanguarda cujo marco inicial se deu com a exposição de mesmo nome, no MAM-RJ, em 1967. A mostra reuniu diversos seguimentos anteriores, como arte concreta, neoconcretismo e nova figuração, em torno da noção de "nova objetividade", que começou a ser definida por Hélio Oiticica na exposição Propostas 65. A criação de objetos e a perspectiva de elaboração de uma vanguarda nacional foram preocupações que pontuaram o surgimento da Nova Objetividade Brasileira. (ALVARADO, Daisy Valle Machado Peccinini de. Figurações Brasil Anos 60: Neofigurações Fantásticas e Neosurrealismo, Novo Realismo e Nova Objetividade. São Paulo: Itaú Cultural/Edusp, 1999; ITAÚ CULTURAL. Enciclopédia de Artes Visuais Itaú Cultural. Disponível em: www.itaucultural.org.br Acesso em $02 / 02 / 2013)$.
} 
perpassavam a ambientação da Guerra Fria também foram elementos significativos da ambiência do período, pois influenciaram a visão de mundo do crítico ${ }^{10}$.

No campo das artes plásticas, os artistas brasileiros sentiram os impasses que envolviam o contexto nacional e internacional, buscando uma arte que, estando mais próxima da realidade cotidiana, fosse capaz de dialogar mais diretamente com o público, ao mesmo tempo em que, sem renunciar às conquistas das vanguardas anteriores, encontravam novos caminhos para responder às demandas da realidade que os cercava. Aliando elementos da Pop Art e do Nouveau Réalisme ao senso construtivo oriundo do Concretismo e do Neoconcretismo, os artistas brasileiros seguiram caminhos que os levaram à nova configuração da Vanguarda Brasileira ${ }^{11}$.

É interessante ressaltar, nesse contexto, que a reflexão do Professor Mario Schenberg a respeito dessas tendências orientou, por exemplo, o surgimento da Nova Objetividade Brasileira. O artista Hélio Oiticica ${ }^{12}$ afirmou que uma das bases teóricas do grupo foi o Novo Realismo de Schenberg, e não o de Pierre Restany, crítico francês que refletiu sobre o Nouveau Réalisme europeu a partir do fim dos anos de 1950. Diante desse quadro, perguntou-se como pode ser entendido o Novo Realismo de Mario Schenberg e como ele estava relacionado à sua visão de Novo Humanismo.

A reflexão de Schenberg acerca da arte, dos artistas, e de seu momento histórico levou em conta elementos que mereceram aprofundamento, na medida em que foram relevantes para os rumos da Vanguarda Brasileira. Diante disso, este estudo objetivou, primeiramente, contribuir para ampliar o conhecimento do legado de Mario Schenberg como intelectual, principalmente sua contribuição enquanto crítico de arte.

A pesquisa analisou o envolvimento de Schenberg no debate das décadas de 1960 e 1970, tendo por base sua atuação nas exposições já apontadas. Evidenciou sua visão de Novo Realismo, dada sua importância no horizonte das Vanguardas Brasileiras, e também alguns dos direcionamentos identificados pelo crítico, como a relação entre a Arte e a Política, o Pensamento Oriental e a Tecnologia, além de outras

\footnotetext{
${ }^{10}$ Enfatiza-se que, em virtude da densidade desse momento artístico e cultural no Brasil, surgiu a necessidade de se fazer escolhas na apresentação desse contexto, trazendo ao percurso expositivo apenas os elementos que motivaram o pensamento e o posicionamento tomado por Mario Schenberg.

${ }^{11}$ Cf. AJZENBERG, Elza. Exercícios Estéticos da Liberdade. São Paulo: ECA USP, 1989 (tese de livre docência) e GOLDFARB, José Luiz. Voar também é com os Homens. São Paulo: EDUSP, 1994.

12 OITICICA, Hélio. Situação da Vanguarda no Brasil (Propostas 66). In FERREIRA, Glória (org.). Crítica de arte no Brasil: temáticas contemporâneas. Rio de Janeiro: Funarte, 2006. O texto foi publicado em 1966, na revista Artes: (São Paulo, 1966. Ano I, n. o 9, nov.-dez, 1966).
} 
tendências emergentes à época, como Arte Mágica, Arte Ecológica e Arte de Participação ${ }^{13}$.

Integraram o corpo teórico desta pesquisa os estudos anteriores sobre o crítico, a saber, Schenberg: crítica e criação de Alecsandra Matias de Oliveira (São Paulo: Edusp, 2011), que destacou sua trajetória intelectual, apresentando sua visão estética sem perder de vista dados biográficos; e Voar também é com os homens: o pensamento de Mario Schenberg de José Luiz Goldfarb (São Paulo: Edusp, 1994), que se dedicou ao pensamento científico, artístico e filosófico do crítico. Tais fontes constituíram alicerces importantes para o desenvolvimento deste estudo. Entretanto, tais estudos não tinham por objetivo ir diretamente ao projeto crítico de Mario Schenberg, mas lançar as bases para que estudos posteriores o fizessem. Nesse momento, o suporte fornecido por estes autores tornou possível levar adiante a investigação de aspectos estéticos de seu pensamento $^{14}$.

A metodologia empregada neste estudo envolveu a análise dos textos críticos escritos no período, que continham reflexões estéticas e propostas dos artistas pontuados por Schenberg. Muitos de seus escritos sobre arte foram publicados em catálogos de mostras e no livro Pensando a Arte (São Paulo: Nova Stella, 1988). Foram raras as publicações desse tipo em jornais ou revistas. Uma grande parte de seus textos críticos está depositada nos arquivos do Centro Mario Schenberg de Documentação da Pesquisa em Arte - ECA USP, somando mais de quatrocentos documentos, a maioria ainda inédita. Neles, encontram-se textos dedicados a diversos artistas, grupos e movimentos que formaram o cenário das artes plásticas durante as décadas de 1940 a $1980^{15}$.

A presente investigação tomou, como fontes primárias, dentre as críticas originais do Centro Mario Schenberg de Documentação da Pesquisa em Arte ECA/USP, os textos escritos na década de 1960 e 1970, bem como os demais livros, artigos e entrevistas nos quais o crítico expôs seu pensamento. Foram utilizados, ainda, os relatórios de pesquisas já realizadas pelo Centro Mario Schenberg e estudos em nível

13 Cf. SCHEnBERG, Mario. Arte de Participação. Arquivo do Centro Mario Schenberg de Documentação da Pesquisa em Arte - ECA/USP. Texto não numerado e não datado.

14 Outro estudo importante sobre o crítico intitula-se Obra Científica de Mario Schenberg, de HAMBURGUER, Amélia Império (São Paulo: EDUSP, 2009).

${ }^{15}$ Enfatiza-se que os textos e materiais de pesquisa referentes ao envolvimento de Schenberg com a Arte Primitiva não integraram o universo desta pesquisa, pois apesar de estarem entre as tendências às quais Schenberg esteve atento no período, não teve relação com o Novo Realismo. 
de pós-graduação existentes sobre o autor, além de obras de referência, artigos e outros documentos ${ }^{16}$.

Com relação à participação de Schenberg nas Bienais de São Paulo, bem como em exposições marcantes nesse período - Opinião 65, Propostas 65, Opinião 66, Propostas 66, além das referidas Bienais paulistas- foram utilizados catálogos e outros materiais. No que diz respeito às Bienais de São Paulo, foram utilizados os principais estudos realizados até o momento, a saber, Bienais de São Paulo: da era do museu à era dos curadores, de Francisco Alambert e Polyana Lopes Canhête (São Paulo: Boitempo, 2004), a edição número 52 da Revista USP (dezembro-fevereiro, 20012002), que contém um dossiê sobre a Bienal Internacional de São Paulo e, por fim, o estudo de Leonor Amarante intitulado As Bienais de São Paulo: 1951 a 1987 (São Paulo: Projeto, 1989). Outra fonte significativa para esta pesquisa foi a documentação encontrada no Arquivo Histórico Wanda Svevo, localizado na sede da Fundação Bienal, no qual foi realizada uma pesquisa em busca de mais detalhes do envolvimento de Mario Schenberg com as Bienais ${ }^{17}$.

Com relação às exposições Opinião 65, Propostas 65, Opinião 66 e Propostas 66, recorreu-se aos textos de críticos e artistas que participaram das exposições e seminários, bem como a catálogos de eventos que tiveram como foco essas exposições. Os textos da época foram encontrados na revista Artes:, que estava em circulação entre as décadas de 1950 a 1960, e no periódico Arte em Revista, organizado pelo Centro de Estudos de Arte Contemporânea da FFLCH-USP, cujos números do ano de 1979 trazem um dossiê sobre os aspectos culturais da década de $1960^{18}$. Em 1995, o Centro Cultural Banco do Brasil realizou a exposição Opinião 65 - 30 anos (Janeiro: Centro Cultural Banco do Brasil, 1995), cujo catálogo foi utilizado nesta pesquisa. Dez anos antes, a Galeria de Arte Banerj realizara a quinta edição de seu Ciclo de Exposições sobre Arte no Rio de Janeiro, tendo por objeto Opinião 65 (Rio de Janeiro: Galeria de Arte Banerj, 1985), cujo catálogo traz um importante texto de Frederico Morais, curador da mostra. Foi significativo, ainda, o estudo de Daisy V. M. Peccinini Alvarado, intitulado

\footnotetext{
${ }^{16}$ Para aprofundar esses aspectos, foram importantes também os livros Pensando a Física (São Paulo: Nova Sttela, 1990), Diálogos com Mario Schenberg (São Paulo: Nova Sttela, 1985) e Mario Schenberg: Entre-Vistas (São Paulo: Perspectiva, 1984).

${ }^{17}$ No que tange ao contexto político e à ação da ditadura militar na Universidade de São Paulo, foi relevante o estudo de CLEMENTE, José Eduardo Ferraz. Ciência e política durante a ditadura militar: o caso da comunidade brasileira de físicos (1964-1979). Salvador: Universidade Federal da Bahia, Instituto de Física, 2005. (dissertação de Mestrado).

${ }^{18}$ Esse material foi assinalado em AIZENBERG, Elza. Exercícios Estéticos da Liberdade (São Paulo: ECA USP, 1989, tese de livre docência).
} 
Figurações Brasil Anos 60: Neofigurações Fantásticas e Neosurrealismo, Novo Realismo e Nova Objetividade (São Paulo: Itaú Cultural/Edusp, 1999).

Ao longo do percurso expositivo foram realizadas leituras de obras de arte envolvidas na investigação, a partir dos direcionamentos dados por Mario Schenberg. Também foram mobilizadas fontes que continham informações sobre a biografia, trajetória artística e imagens das obras analisadas.

No presente estudo, destacou-se a obra de três artistas com os quais Mario Schenberg manteve proximidade no período, a saber, Maurício Nogueira Lima, Mira Schendel e Lygia Clark. Escrevendo sobre esses artistas, o crítico sublinhou conceitos e fez observações que ajudaram a situá-los no contexto e aprofundaram conhecimento sobre os mesmos.

Maurício Nogueira Lima (Recife/PE 1930 - Campinas/SP 1999) conviveu intensamente com Mario Schenberg, principalmente na década de 1960. Vindo da pesquisa formal do Concretismo, o artista explorou, na década de 1960, a relação entre Arte e Política utilizando elementos do Novo Realismo e da Pop Art. Mira Schendel (Zurique, Suíça 1919 - São Paulo/SP 1988) trabalhou com um elemento que não participa apenas do projeto crítico de Mario Schenberg, mas também de sua visão de mundo: o contato com a Arte e o Pensamento do Oriente. Para o crítico, a obra da artista opera uma síntese entre Ocidente e Oriente ${ }^{19}$. Lygia Clark (Belo Horizonte/MG 1920 Rio de Janeiro/RJ 1988) foi ligada ao movimento Concreto do Rio de Janeiro, ao Neoconcretismo e, depois à Nova Objetividade Brasileira, seguindo os caminhos da Arte de Participação. Para Schenberg, a artista estava em profundo diálogo com os problemas universais e tensões de sua época ${ }^{20}$.

Com base nessa pesquisa, foi feita uma reflexão sobre a postura crítica de Mario Schenberg em relação aos artistas que encontravam seus caminhos em meio à arte de vanguarda do período. Isso foi feito com base na análise de seus escritos, bem como nos depoimentos de diversos artistas que conviveram com o crítico ${ }^{21}$.

Dessa forma, foram organizadas as seguintes partes:

O primeiro capítulo, intitulado Porque opinar é preciso, buscou evidenciar o contexto do envolvimento de Mario Schenberg nas Bienais de São Paulo enquanto

${ }^{19}$ SCHENBERG, Mario. Pensando a Arte. São Paulo Nova Stella, 1988.

${ }^{20}$ SCHENBERG, Mario. Pensando a Arte. São Paulo Nova Stella, 1988.

${ }^{21}$ Foi de extrema importância, ainda, o estudo de FERREIRA, Glória \& COTRIM Cecília, que acompanha a coletânea Escritos de artistas: anos 60/70 (Rio de Janeiro: Jorge Zahar Ed., 2009), tendo por assunto a importância da conceituação na arte que nascia no período e da importância dos textos que os artistas a respeito de suas próprias obras. 
membro do Júri de Seleção (1965, 1967 e 1969), bem como sua contribuição ao momento efervescente das mostras Opinião 65, Opinião 66, Propostas 65 e Propostas 66.

O segundo capítulo, Schenberg e Vanguardas: primeiras formulações, realizou uma análise das principais tendências apontadas pelo crítico na década de 1960, na qual o crítico aprofundou seu conhecimento sobre o Nouveau Réalisme e a Pop Art, cujos encaminhamentos dirigiram o debate entre artistas, críticos e intelectuais para conceituações a respeito do que se passava então no meio artístico brasileiro. Foi analisado o ponto de vista de Schenberg a respeito dos artistas Maurício Nogueira Lima e Lygia Clark.

Em Desdobramentos: a década de 1970, o terceiro e último capítulo, surgiram formulações de um período no qual Schenberg já tinha uma concepção mais consolidada acerca dos rumos da arte desde Opinião 65. Foram analisadas novas tendências percebidas pelo crítico, a saber, Arte Ecológica e Arte Catastrófica, ligadas à relação entre Arte e Natureza. A partir disso foram analisadas as considerações de Schenberg sobre a artista Mira Schendel. Por fim, realizou-se uma análise da postura de Mario Schenberg enquanto crítico de arte diante das transformações profundas pelas quais passou a arte do período. 


\section{Porque opinar é preciso: Schenberg e seu contexto}

Eu sempre fui um homem de posições politicas definidas. Sempre que tenho certeza, alguma certeza, tomo posições políticas definidas. É um dever que a gente tem. Mesmo que a gente erre. Assim acho que ajudamos mais as pessoas. Temos que dar opiniões mesmo que não possamos provar, isso pode estimular nos outros a procura, para que tomem direções. É o problema de Sócrates, que era um "partejador" de idéias, ele tirava as idéias que estavam incubadas nas cabeças das pessoas. Eu gostaria de fazer isso. E faço, mas sem a eficiência dele $e^{l}$

Mario Schenberg

Tudo o que é realmente grande e inspirador é criado pelo indivíduo que pode trabalhar em liberdade ${ }^{2}$.

Albert Einstein

\section{Bienais de São Paulo}

\section{Retrospectiva de Alfredo Volpi - VI Bienal (1961)}

A VI Bienal do Museu de Arte Moderna de São Paulo teve lugar no Pavilhão Armando Arruda Pereira (Pavilhão da Bienal), entre 1 de outubro e 21 de dezembro de 1961. Tendo como diretor geral o crítico de arte Mario Pedrosa, a mostra reuniu 651 artistas provenientes de 50 países, expondo ao público quase 5.000 obras $^{3}$.

\footnotetext{
${ }^{1}$ In HAMBURgUER, Amélia Império. Nota biográfica e entrevista com Mario Schenberg (Novembro, 1983). São Paulo: Instituto de Física, Universidade de São Paulo, 1984, p. 28. Foi mantida a grafia original.

${ }^{2}$ COHEN, Marilene. Albert Einstein. Col. Personagens que marcaram época. São Paulo: Globo, 2007.

${ }^{3}$ FUNDAÇÃO BIENAL. Bienal a Bienal. Disponível em: http:/www.bienal.org.br/FBSP/pt/AHWS/BienalaBienal/Paginas/6BienalSaoPaulo.aspx?selected=6 Acessado em 15/01/2013.
} 
Chegando a sua sexta edição, o evento já tinha suscitado diversas polêmicas. Desde a repercussão do apoio de Nelson Rockefeller quando de sua criação, passando pelo gigantismo das sucessivas edições, até os debates acerca da abstração versus figuração e da emergência das vanguardas dos anos de $1960^{4}$. Pode-se dizer que a cada dois anos, em maior ou menor medida, escolhas e renúncias dos organizadores da Bienal de São Paulo catalisavam e inventariavam os debates em voga na esfera cultural e artística do país.

Esta edição foi a última ligada ao Museu de Arte Moderna de São Paulo, (MAM-SP), fundado por Francisco Matarazzo Sobrinho (conhecido como Ciccillo Matarazzo) em $1948^{5}$. Foi também a última edição que contou com uma organização centralizada na figura de um Diretor Geral, função ocupada então por Mário Pedrosa. Da VII Bienal em diante, a organização do evento contaria apenas com Comissões de Assessoria e, a partir da XI Bienal, em 1971, com uma Assessoria Técnica ${ }^{6}$. Após a separação entre a Fundação Bienal e o MAM - SP, o crítico de arte participou da organização de algumas edições seguintes, porém ocupando outras funções.

Com Mário Pedrosa na direção geral da mostra, a expectativa era que a edição de 1961 tivesse um caráter fortemente pautado pelas pesquisas de vanguarda. Contudo, sua proposta foi mais tímida, apoiando-se em retrospectivas históricas. Várias representações internacionais tiveram caráter museológico. Sobre isso, a pesquisadora Leonor Amarante observou que:

\begin{abstract}
Seu brilho [de Mário Pedrosa] incontestável como crítico e teórico não foi o mesmo na função de curador. A exposição foi pouco instigante, faltou-lhe ousadia. O espaço que dedicou para obras de caráter histórico e museológico foi excessivo. Embora a maioria das salas fosse interessante, exposições dessa natureza não se justificam em bienais que pretendiam enfocar o que acontecia na arte contemporânea ${ }^{7}$.
\end{abstract}

\footnotetext{
4 ALAMBERT, Alambert \& Polyana CANHÊTE. Bienais de São Paulo: da era do museu à era dos curadores. São Paulo: Boitempo, 2004.

${ }^{5}$ Entre os anos de 1961 e 1966 deu-se o processo de desvinculação da Bienal em relação ao MAM-SP, passando o evento a ser organizado pela Fundação Bienal, que obteria recursos municipais e estaduais para financiar suas atividades, mas continuaria sob o comando de Ciccillo Matarazzo (ALAMBERT, Alambert \& Polyana CANHÊTE. Bienais de São Paulo: da era do museu à era dos curadores. São Paulo: Boitempo, 2004).

6 A comissão artística deixou de existir, tendo sido substituída por uma comissão cujos integrantes eram indicados por Ciccillo Matarazzo, presidente da Fundação Bienal, criada no ano seguinte (1962). Nem sempre havia nessas comissões conhecedores de arte, o que comprometia a qualidade da mostra. Essa crítica acompanhou as Bienais desde sua separação do MAM-SP. Cf. ALAMBERT \& CANHÊTE (2004); AMARANTE (1989).

${ }^{7}$ AMARANTE, Leonor. As Bienais de São Paulo: 1951 a 1987. São Paulo: Projeto, 1989, p. 108.
} 
Dentro desse projeto, estavam previstas, na representação brasileira, salas especiais para os laureados das primeiras edições da Bienal $^{8}$. Coube a Mario Schenberg a organização de uma retrospectiva da obra de Alfredo Volpi, que ocupou uma das salas especiais da representação brasileira da VI Bienal de Arte de São Paulo ${ }^{9}$. O pintor das bandeirinhas dividiu com Di Cavalcanti o Prêmio Nacional de Pintura na II Bienal, em 1953, escolha que se deu no contexto do debate entre o realismo social e o abstracionismo emergente ${ }^{10}$.

Schenberg era, já na época, um dos maiores conhecedores da personalidade e da obra do artista, tendo sido o primeiro a perceber, por volta dos anos de 1940, a importância da obra do pintor operário de origem humilde ${ }^{11}$. Mario Schenberg havia organizado, em 1944, a primeira exposição individual de Alfredo Volpi, para a qual fotografara as obras e escrevera o texto de apresentação para o catálogo da mostra ${ }^{12}$.

Em carta datada de 2 de fevereiro de 1961, Mário Pedrosa escreve a Mario Schenberg confirmando o acerto prévio feito em conversa telefônica e manifestando satisfação em confiar ao crítico a organização da retrospectiva de Volpi. Essa tarefa tinha sido proposta inicialmente a Theon Spanoudis, que foi escolhido pelo pintor, mas não pôde aceitar a incumbência, pois estaria em viagem no período em questão ${ }^{13}$.

Para organizar a retrospectiva de Alfredo Volpi, Mario Schenberg teve que contornar uma dificuldade: reunir trabalhos de todas as fases de um pintor cuja carreira fora iniciada na década de 1920, junto ao Grupo Santa Helena. Contando então com uma trajetória de quatro décadas, que compreenderam inúmeras fases, sua obra oferecia um desafio e tanto à realização de uma exposição retrospectiva. Essa dificuldade foi ainda maior com relação aos trabalhos anteriores à década de 1940, que já estavam bastante dispersos. No texto de apresentação da mostra, o crítico observou que a "[...] maior parte dos trabalhos de decoração

\footnotetext{
${ }^{8}$ O projeto foi apresentado por Mário Pedrosa, nesses termos, aos críticos convidados para organizar as salas especiais, conforme o modelo da carta-convite enviada, com pequenas mudanças, a cada um deles (Arquivo Wanda Svevo/ Fundação Bienal).

${ }^{9}$ FUNDAÇÃO BIENAL. VI Bienal. (catálogo de exposição) São Paulo: Fundação Bienal, 1961.

${ }^{10}$ AMARANTE, Leonor. As Bienais de São Paulo: 1951 a 1987. São Paulo: Projeto, 1989.

11 AJZENBERG, Elza. Mario Schenberg - O Crítico. In AGUILAR, José Roberto. O mundo de Mario Schenberg. São Paulo: Casa das Rosas, 1996. Em 1953, Schenberg havia retornado ao Brasil após uma estadia de cinco anos na Bélgica, nos quais lecionou na Universidade de Bruxelas, dedicando-se às atividades científicas. Foi nomeado Diretor do Departamento de Física da então chamada Faculdade de Filosofia, Ciências e Letras da USP, o que diminuiu sua disponibilidade de tempo para a crítica de arte. E, 1961, quando deixou o cargo, Schenberg pôde retomá-la de modo mais sistemático, principalmente por meio do contato com Alfredo Volpi e Mário Pedrosa. Até 1969, quando foi afastado da Universidade de São Paulo, Schenberg atuou no meio artístico com menor intensidade, o que não quer dizer que sua crítica de arte tenha sido menos significativa.

${ }_{12}$ OLIVEIRA, Alecsandra Matias de. Schenberg: crítica e criação. São Paulo: EDUSP, 2010, p. 108.

13 Carta de Mário Pedrosa a Mario Schenberg, de 02 de fevereiro de 1961; carta de Mário Pedrosa a Theon Spanudis, de 22 de dezembro de 1960 (Arquivo Histórico Wanda Svevo). A resposta de Theon Spanoudis não foi encontrada no Arquivo Histórico da Bienal, mas Pedrosa faz referência a ela na primeira carta mencionada, bem como ao motivo que o levou a não aceitar o convite.
} 
de residências foram destruídos. Com grande esforço foi possível reunir uma coleção reduzida de seus quadros do período de 1915-1940 para a presente retrospectiva"14.

Figuraram na mostra 95 obras, em ordem cronológica, num percurso que cobriu desde 1915, como a tela Casebre, à pesquisa de 1961, com Bandeirolas no Espaço ${ }^{15}$. Para Leonor Amarante, a sala especial teve o mérito de ter sido "a primeira oportunidade de se ver quase todas as [...] fases" do pintor ${ }^{16}$.

Foram inúmeras as negociações com proprietários de obras do pintor. No Arquivo Histórico Wanda Svevo estão depositados inúmeros recibos de empréstimo e devolução de obras pertencentes a diversos proprietários, entre eles, Francisco Matarazzo Sobrinho, Mário Pedrosa, o pintor Bruno Giorgi e o próprio Mario Schenberg ${ }^{17}$.

No texto de apresentação da retrospectiva, o crítico busca dar ao público a dimensão das fases da pesquisa de Alfredo Volpi, apresentando alguns aspectos de sua extensa produção. Ao destacar a capacidade de síntese do pintor, seja na captação da essência da atmosfera de cidadezinhas, subúrbios e praias, seja nas composições da fase do abstracionismo geométrico, Mario Schenberg utiliza elementos da pintura oriental: "Volpi evoca a arte inefável dos paisagistas místicos da China e do Japão [...], mas sempre como um homem do povo de São Paulo"18.

O crítico identifica a síntese operada pelo pintor, aliada à musicalidade de suas composições, à dimensão do trabalho dos artistas orientais que, no processo de seu aprendizado, buscavam na simplificação do desenho e no ritmo do traço uma expressividade mais profunda.

Para Mario Schenberg, Volpi é o pintor do espaço metafísico, repleto de musicalidade, no qual a cor não está a serviço da sensualidade (aqui entendida como aspecto do sensível, da sensação visual, e não no sentido do senso comum), mas da expressão de uma "espiritualidade fria e vibrante, um sentimento cósmico transcendendo a sensualidade das aparências"19.

Também são examinadas no texto as influências do abstracionismo geométrico e do concretismo, enquanto movimentações mais recentes de sua obra naquele momento. Mario

${ }^{14}$ SCHENBERG, Mario. Alfredo Volpi. In FUNDAÇÃO BIENAL. VI Bienal. (catálogo de exposição) São Paulo: Fundação Bienal, 1961, pp.38-39.

${ }^{15}$ FUNDAÇÃO BIENAL. VI Bienal. (catálogo de exposição) São Paulo: Fundação Bienal, 1961.

${ }^{16}$ AMARANTE, Leonor. As Bienais de São Paulo: 1951 a 1987. São Paulo: Projeto, 1989, p. 117.

${ }^{17}$ Arquivo Histórico Wanda Svevo, Fundação Bienal.

${ }^{18}$ SCHENBERG, Mario. Alfredo Volpi. In FUNDAÇÃO BIENAL. VI Bienal. (catálogo de exposição) São Paulo: Fundação Bienal, 1961, p. 37.

${ }^{19}$ SCHENBERG, Mario. Alfredo Volpi. In FUNDAÇÃO BIENAL. VI Bienal. (catálogo de exposição) São Paulo: Fundação Bienal, 1961, p. 37. 
Schenberg indica que, de início, elas pareceram nocivas ao desenvolvimento da pesquisa de Volpi, preocupação que, mais tarde, foi afastada pelo

\begin{abstract}
poderoso temperamento artístico de Volpi pôde [que] receber a influência do abstracionismo geométrico e do concretismo sem perder as suas características próprias. O resultado foi uma maior liberdade, aliada a uma depuração da composição e do colorido, que lhe deram uma admirável capacidade de síntese ${ }^{20}$.
\end{abstract}

Essa libertação da representação, prossegue o crítico, permitiu ao pintor desenvolver ainda mais seu senso de espacialidade pura, notável desde suas marinhas de Itanhaém (19401942). O pintor conseguiu plasmar, usando grandes massas de tons puros, uma espacialidade de vibração belíssima que, segundo o crítico, foi criação original sua. Os espaços, coloridos uniformemente, buscavam afastar a impressão de matéria.

Nos desdobramentos dos dois anos anteriores, porém, Volpi vinha se afastando do concretismo: estava voltando "à procura de matéria, e mesmo da pincelada, retomando de modo novo métodos tradicionais da pintura ocidental. [...] [N]as composições semi-abstratas ou abstratas surgem cada vez mais linhas e curvas irregulares" ${ }^{21}$.

Apesar de apresentarem muitas qualidades, como a beleza da composição, a pureza do colorido e os temas populares, o conjunto da obra de Volpi produzida sob encomenda se apresenta menos interessante, para o crítico, que as telas pintadas na trilha de sua pesquisa pessoal - abstrata ou semi-abstrata - do mesmo período.

Mario Schenberg conclui a apresentação da sala especial mencionando a formação do pintor, autodidata por excelência, isolada das tendências artísticas de então (primeiro tempo Modernista: décadas de 20 e 30). Apesar de ter podido, nos anos de 1950, viajar à Europa e aprimorar seu aprendizado, tendo conhecido os primitivos italianos que tanto o impressionaram, e de ter sido depois influenciado pelo concretismo, o sentimento popular não deixou Volpi: seus ecos estavam presentes nas hoje famosas bandeirinhas dos anos de 1950 e 1960.

\footnotetext{
${ }^{20}$ SCHENBERG, Mario. Alfredo Volpi. In FUNDAÇÃO BIENAL. VI Bienal. (catálogo de exposição) São Paulo: Fundação Bienal, 1961, p. 38.

${ }^{21}$ SCHENBERG, Mario. Alfredo Volpi. In FUNDAÇÃO BIENAL. VI Bienal. (catálogo de exposição) São Paulo: Fundação Bienal, 1961, p. 38.
} 


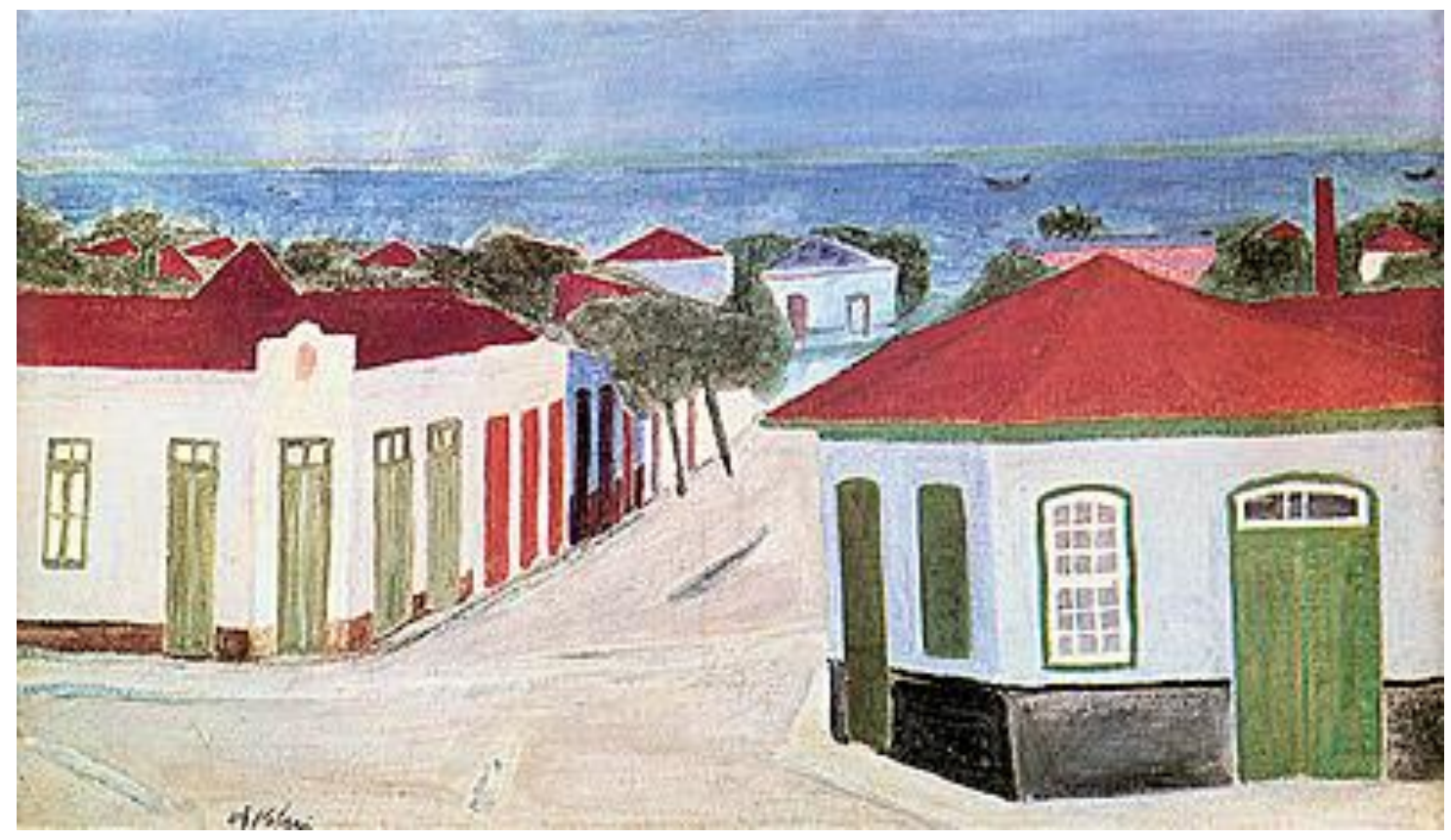

Figura 2 - Alfredo Volpi, [Vista de Itanhaém] [Marinha de Itanhaém], década de 1940, têmpera sobre tela, 45 x $76 \mathrm{~cm}$. Coleção Particular. Reprodução fotográfica de autoria desconhecida.

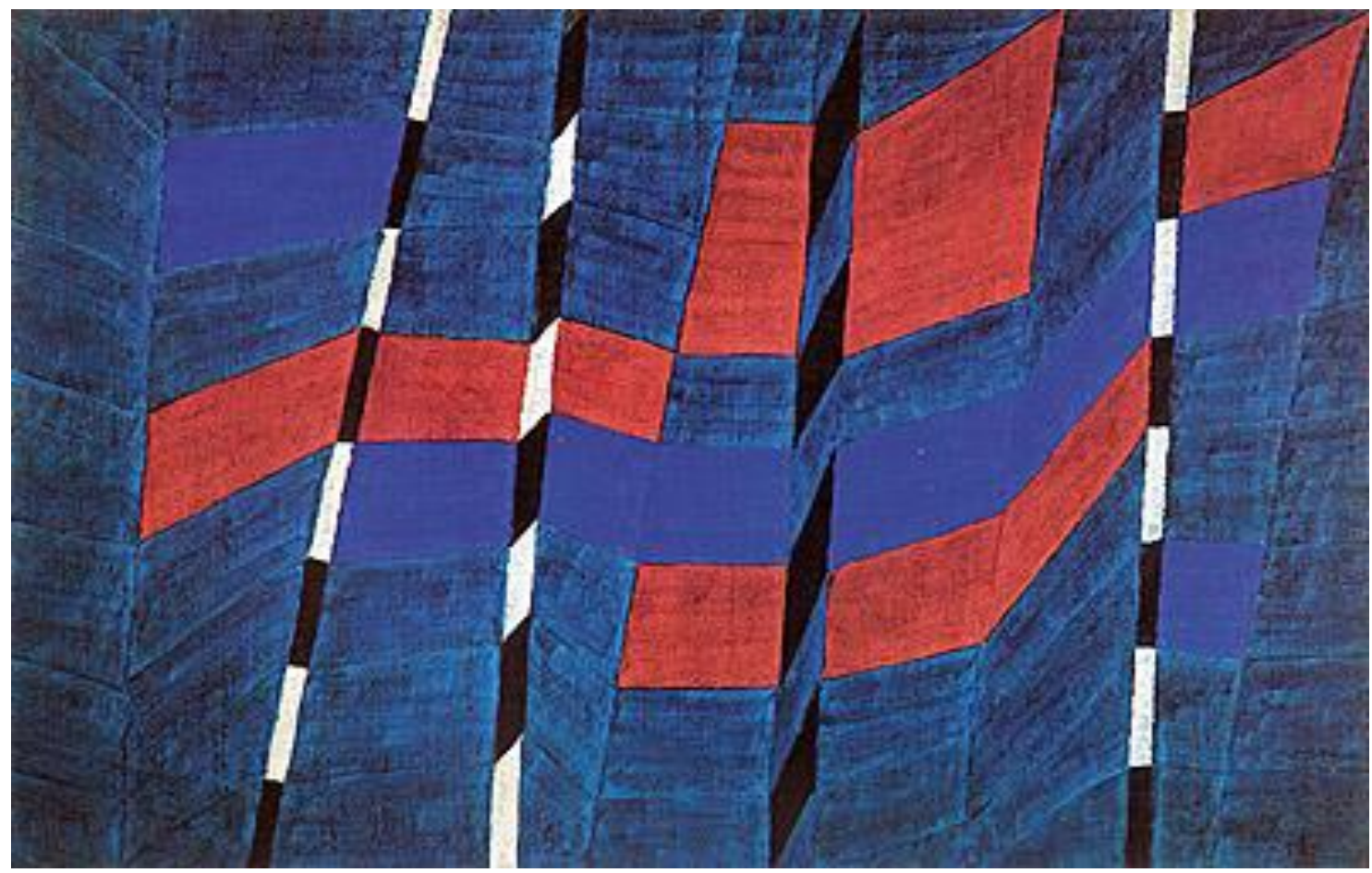

Figura 1 - Alfredo Volpi, [Composição com Faixas], déc. 1960, têmpera sobre tela, 75 x 110,3 cm. Coleção Particular. Reprodução fotográfica Horst Merkel. 


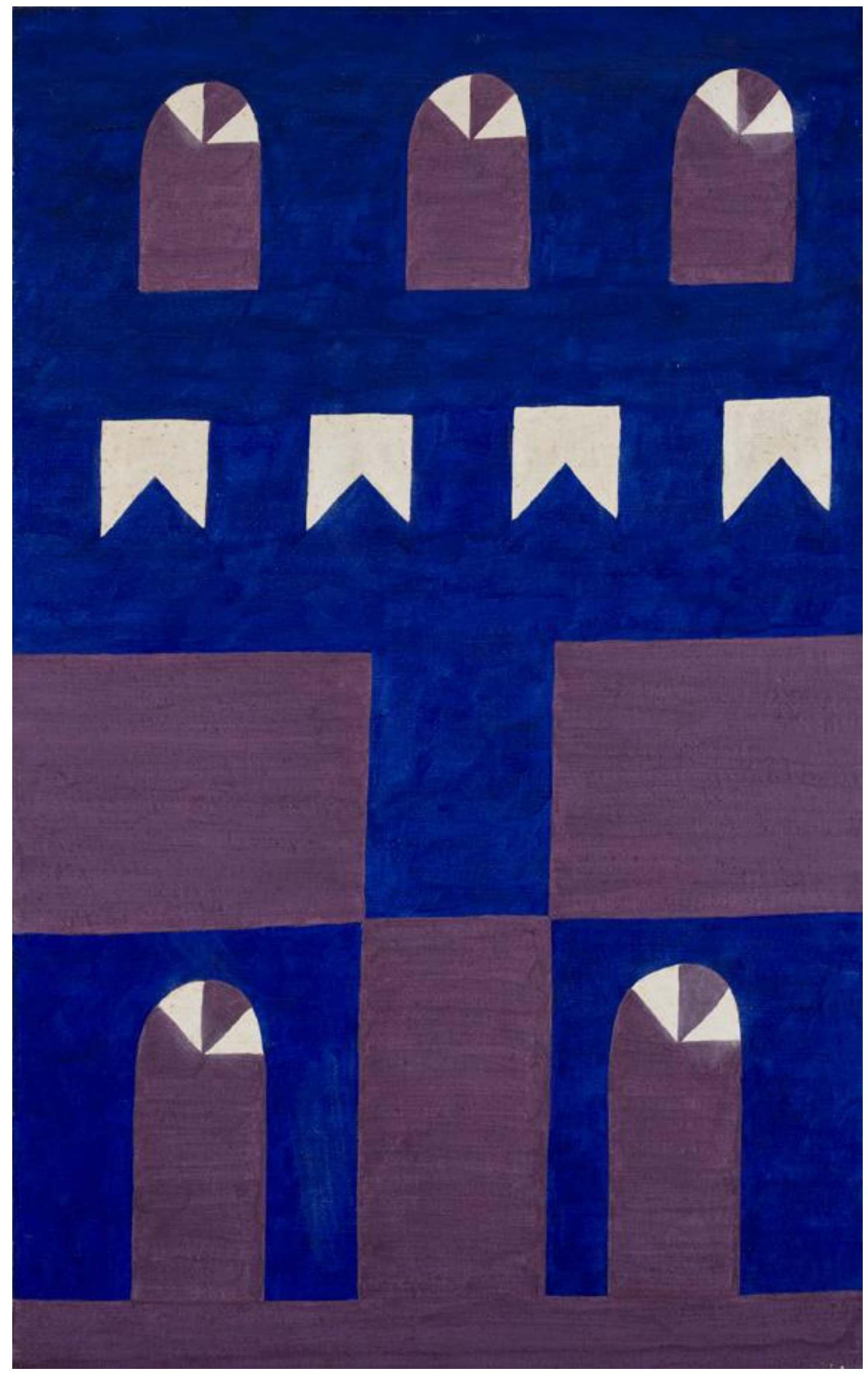

Figura 3 - Alfredo Volpi, Fachada com Bandeiras, 1959, Têmpera sobre tela, 116 x $72 \mathrm{~cm}$. Acervo do Museu de Arte de São Paulo - MASP, doação de Ernest Wolf. 
Júri de Seleção: VIII, IX e X Bienais (1965, 1967 e 1969)

\section{5: Manifesto dos 4}

Para Mario Schenberg, cuja esfera de atuação orbitava entre sua atividade acadêmica como docente na então FFCL (Faculdade de Filosofia, Ciências e Letras da USP), a militância política e a crítica de arte, o ano de 1965 foi bastante intenso e repleto de acontecimentos marcantes. Exposições significativas tiveram lugar nesse ano: Opinião 65, no Museu de Arte Moderna do Rio de Janeiro, e Propostas 65, na Fundação Armando Álvares Penteado ${ }^{22}$. Todas contaram, em maior ou menor medida, com a sua participação.

Comunista assumido ${ }^{23}$, Mario Schenberg também teve que lidar com a perseguição política. As complicações decorrentes do momento político de então prejudicaram também o exercício de suas atividades enquanto pesquisador e docente na Universidade de São Paulo. Único convidado latino-americano para um importante congresso no Japão, Mario Schenberg só conseguiu participar do evento por causa da repercussão internacional decorrente de sua prisão, pois seu status de renomado cientista projetou internacionalmente a arbitrariedade do regime militar recentemente instaurado no país.

Nesse momento de agitação política e cultural, Mario Schenberg voltou a se envolver com a organização das Bienais, dessa vez como membro do Júri Nacional de Seleção. Participou, assim, da organização da VIII, IX e X bienais de Arte de São Paulo (em 1965, 1967 e 1969), para a qual foi eleito pelos próprios artistas (AGUILAR, 1996).

A VIII Bienal de Arte de São Paulo, formalmente desvinculada do Museu de Arte Moderna, esteve aberta entre 4 de setembro e 28 de novembro de 1965. A mostra foi organizada pelas assessorias de artes plásticas (Geraldo Ferraz, Sérgio Milliet e Walter Zanini), teatro (Aldo Calvo e Sábato Magaldi), arquitetura (Oswaldo Corrêa Gonçalves) e artes gráficas (Jannar Murtinho Ribeiro). Em seus quase três meses de duração, foram apresentados ao público 653 artistas de 54 países, totalizando 4.054 obras $^{24}$.

\footnotetext{
${ }^{22}$ A participação de Schenberg nessas duas exposições, além de Opinião 66 e Propostas 66, será explorada no segundo momento deste capítulo.

${ }^{23}$ Na década de 1960, Mario Schenberg foi membro titular do Comitê Central do Partido Comunista. Cf. Dina Kinoshita. A Política para Mario Schenberg, s.p. (texto digitado - Arquivo do Centro Mario Schenberg de Documentação da Pesquisa em Artes - ECA/USP).

${ }^{24}$ FUNDAÇÃO BIENAL. Bienal a Bienal. Disponível em: http://www.bienal.org.br/FBSP/pt/AHWS/BienalaBienal/Paginas/6BienalSaoPaulo.aspx?selected=6 Acesso em $15 / 01 / 2013$
} 
Nessa edição, já era possível perceber que mudanças profundas ocorreriam na arte, o que apareceria com mais força na IX Bienal. A Pop Art já despontava como tendência emergente, assim como a Arte Povera (que trabalhava com sucata, refugos e materiais semelhantes) e a quebra dos suportes tradicionais. Para Leonor Amarante, a mostra estava bem distribuída, abrigando as novas figurações, concretismo, surrealismo e arte fantástica ${ }^{25}$.

A sala especial internacional "Do Surrealismo à Arte Fantástica", de caráter histórico, foi o destaque da VIII Bienal, e teve um catálogo à parte, rico em imagens das obras exibidas. Nela figuraram sessenta artistas, entre os quais estavam Marcel Duchamp, Max Ernest, Jean Arp, Marcel Chagal, Joan Miró, Man Ray, Paul Klee, Magritte, Francis Picábia e Frida Kahlo.

Já a representação brasileira, apesar de ter recusado $80 \%$ dos artistas submetidos ao Júri de Seleção (superando as bienais anteriores) ${ }^{26}$, era bem maior que as estrangeiras, como ocorria desde sua primeira edição. O elevado número de artistas recusados representava uma tentativa, por parte da Bienal, de elevar a qualidade da representação brasileira e, ao mesmo tempo, reduzir suas dimensões. Esses dois aspectos organizacionais vinham sofrendo ataques por parte de artistas e críticos de arte.

Enquanto os artistas criticavam a falta de critério de avaliação que transparecia nas escolhas do Júri de Seleção, o alvo dos críticos de arte, embora com diferenças de opinião, era o inchaço da representação brasileira, que aceitava artistas que não estavam à altura da Bienal e parecia não saber separar o joio do trigo.

Contudo, era fato reconhecido que, nas condições oferecidas ao corpo de jurados, apesar da boa vontade com que desenvolviam os trabalhos de seleção, era inevitável se chegar a decisões totalmente acertadas. Paulo Mendes de Almeida reconhece que, nesse contexto, o veredito do Júri era "frequentemente injusto, por mais isento que seja, embora animado dos melhores propósitos”, conforme acreditava ser o caso da VIII Bienal. O crítico acrescentou, ainda: "[v]endo quatrocentas obras, em média, por dia, que critério, que metro, que medida de relação podem observar os membros desse colégio"? ${ }^{27}$

A isso era atribuída a falta de unidade da representação brasileira, ressaltada por Aracy Amaral, que a comparava a um salão, no qual havia de tudo um pouco, "como se o Brasil tivesse a preocupação de mostrar que pode apresentar de tudo para todos os gostos" 28 . Nesse sentido, o conjunto brasileiro, constituído por grande número de artistas participantes, cada

\footnotetext{
${ }^{25}$ AMARANTE, Leonor. As Bienais de São Paulo: 1951 a 1987. São Paulo: Projeto, 1989.

${ }^{26} \mathrm{O}$ corte foi duro, registrado o maior índice de recusa de todas as bienais: $80 \%$ dos inscritos foram recusados. Correio da Manhã (Estado da Guanabara), 19/05/1965.

${ }^{27}$ ALMEIDA, Paulo Mendes de. A próxima Bienal. O Estado de São Paulo, São Paulo (capital), 26/06/1965.

${ }^{28}$ AMARAL, Aracy. Revisão da VIII Bienal. O Estado de São Paulo, 11/12/1965.
} 
um com poucas obras, tornava-se confuso e assemelhava-se a uma feira de arte. Segundo a autora, essa estrutura já estava superada e precisava ser revista pela Fundação Bienal ${ }^{29}$.

A mostra abria as portas ao grande público um ano e meio depois do golpe militar de 1964. Apesar de a censura ter sido mais intensa a partir de 1968, em decorrência do Ato Institucional $n^{\circ} 5^{30}$, a repressão já começava a fazer parte do horizonte cultural e político do país. Repercutindo imediatamente na estrutura de poder da Universidade de São Paulo, foi no ambiente acadêmico que a perseguição política atingiu Mario Schenberg.

O eminente físico foi preso durante a primeira operação militar efetuada após o golpe, denominada "Operação Limpeza”, cujo intuito "era 'limpar' o País da ameaça comunista, recolhendo todos aqueles que representassem uma ameaça à Segurança Nacional”31. O catedrático da USP e crítico de arte foi preso em 2 de abril de 1964, mas voltou à liberdade cerca de 50 dias depois.

Em outubro do mesmo ano foram instaurados novos inquéritos e, mais uma vez, foi decretada a prisão preventiva de Mario Schenberg, que iria participar de um importante evento científico no Japão no ano seguinte, quando o físico pediu permissão para viajar. Isso porque, devido ao fato de estar respondendo a processos, não poderia sair do país ${ }^{32}$. O crítico permaneceu foragido durante alguns meses até que, em atitude estratégica, entregou-se à polícia, já em $1965^{33}$.

Estratégica, pois Schenberg foi o único cientista latino-americano convidado para o Congresso Internacional de Partículas Elementares que seria realizado em Tóquio (Japão). Ao se apresentar à polícia, apostou na força da repercussão internacional que a prisão de um renomado cientista atrairia, o que de fato aconteceu ${ }^{34}$. $\mathrm{O}$ depoimento da artista Lourdes Cedran $^{35}$ demonstra a consciência do crítico a respeito do desfecho de sua atitude:

\footnotetext{
${ }^{29}$ AMARAL, Aracy. Revisão da VIII Bienal. O Estado de São Paulo, 11/12/1965.

${ }^{30}$ SCHWARZ, Roberto. Cultura e Política, 1964-69, in O Pai de Família e outros estudos. Rio de Janeiro: Paz e Terra, 1978.

${ }^{31}$ CLEMENTE, José Eduardo Ferraz. Ciência e política durante a ditadura militar: o caso da comunidade brasileira de físicos (1964-1979). Salvador: Universidade Federal da Bahia, Instituto de Física, 2005. (dissertação de Mestrado), p. 97.

32 “Começava uma batalha judicial pela liberdade, pela defesa da Cátedra de Mário Schenberg e até mesmo pelos vencimentos cortados durante o período em que esteve ameaçado de prisão. Chegou a ter, durante esse período, a sua biblioteca destruída e os seus quadros [...] dilacerados pelos policiais que conduziam as 'investigações' em busca de provas que pudessem incriminá-lo”. CLEMENTE, José Eduardo Ferraz. Ciência e política durante a ditadura militar: o caso da comunidade brasileira de físicos (1964-1979). Salvador: Universidade Federal da Bahia, Instituto de Física, 2005. (dissertação de Mestrado), p. 102.

${ }^{33}$ Schenberg foi preso anteriormente, em 1948, sob acusação de subversão à ordem pública, tendo sido liberado alguns meses depois. Logo após, retornou à Europa, mais precisamente à Bélgica, onde permaneceu até 1953 (AGUILAR, José Roberto. O mundo de Mario Schenberg. São Paulo: Casa das Rosas, 1996).

34 “(...) [Schenberg] resolveu então se entregar no exército do Ibirapuera porque sabia que no momento em que se entregasse, chegariam centenas de telegramas do mundo inteiro pedindo sua presença no congresso. Assim, fez com que o exército fosse obrigado a dar o passaporte para ele ir ao congresso." (GOLDFARB. José Luis.
} 
Naqueles dias, Mário deveria viajar para o Japão para um encontro científico da maior importância. Ele era o único latino-americano convidado. Em um lance estratégico ele decidiu entregar-se à polícia, e com isso chamou a atenção da comunidade científica internacional para as arbitrariedades do regime brasileiro. Em seguida telefonou para a Escola e me disse: "já estou preso, venha visitar-me no batalhão da Rua Jorge Miranda". Embora estranhando o fato, fui ao seu encontro. [...] Contou-me que seu advogado, Dr. Aldo Lins e Silva, já estava tratando de tudo e que provavelmente seria libertado no mesmo dia. Disse então que ficasse calma e que esperasse na Bienal. [...]

Às nove da noite ele chegou na Bienal para alegria e surpresa de todos e no dia seguinte embarcou para o Japão, pois lhe foi concedido um habeas-corpus.

O crítico obteve uma ordem judicial que suspendeu sua prisão e pôde chegar ao seu destino a tempo de assistir ao fim da conferência. Ainda nesse ano, foi absolvido nos processos que haviam sido instaurados contra ele e retornou à Universidade de São Paulo.

Durante a década de 1960, Schenberg encontrou entre os artistas o apoio que possibilitou sua atuação, mesmo sob os mandados de prisão e a perseguição política de que foi alvo. Apesar de ter vivido entre a prisão e a ilegalidade em vários momentos, o crítico se recusou ao exílio no exterior por não poder tirar passaporte e por causa de seu senso de cidadania $^{36}$.

Durante o período em que esteve foragido, contou com a acolhida de diversos artistas que o esconderam da polícia, como mostraram vários depoimentos. Entre eles, o de Lourdes Cedran $^{37}$ :

Conheci o Mário na década de 60, num período de muita agitação política pós-64. [...] Houve muitas prisões. $\mathrm{Na}$ época em que lançaram o Manifesto dos 4 (Mário Schenberg, Leite Lopes, Cruz Costa e Florestan Fernandes) foi anunciada a prisão de Mário. Neste dia ele havia combinado de me encontrar num curso de arte que eu fazia numa escola na Rua Augusta. Ele chegou com o Mário Gruber, que estava com o pé quebrado. Apesar de estar com prisão decretada, ele entrou calmamente, e disse que fôssemos jantar juntos. Em verdade, fomos levá-lo para um esconderijo - a própria casa do Gruber. [...] Fui informada depois que o Mário já não se encontrava na casa do Gruber, mas sim na casa de outros amigos.

José Luis Goldfarb. In AJZENBERG, Elza. In Shenberg: Arte e Ciência. São Paulo: ECA/USP, 1997, p.45). A solidariedade da comunidade científica em nível nacional e internacional já havia se levantado quando de sua última prisão, logo após o golpe. (CLEMENTE, José Eduardo Ferraz. Ciência e política durante a ditadura militar: o caso da comunidade brasileira de físicos (1964-1979). Salvador: Universidade Federal da Bahia, Instituto de Física, 2005. (dissertação de Mestrado), p. 98).

${ }^{35}$ CEDRAN, Lourdes. Lourdes Cedran. In SCHENBERG, Mário. Mário Schenberg: Entre-Vistas. São Paulo: Perspectiva, 1984, pp.68-70.

36 "Schenberg foi aposentado e - diferentemente da maioria dos cientistas que foram cassados pela ditadura dos militares - não saiu do Brasil. Ele tinha propostas para trabalhar em qualquer país do mundo, mas tinha uma enorme determinação de ficar no Brasil. Foi o típico caso que deu trabalho aos militares." (GOLDFARB. José Luis. José Luis Goldfarb. In AJZENBERG, Elza. In Shenberg: Arte e Ciência. São Paulo: ECA/USP, 1997, p.44).

${ }^{37}$ CEDRAN, Lourdes. Lourdes Cedran. In SCHENBERG, Mário. Mário Schenberg: Entre-Vistas. São Paulo: Perspectiva, 1984, pp. 66-8. 
Nesse período tumultuado, também foi importante o contato entre Schenberg e os artistas com os quais conviveu. Quando não estava sendo procurado, eram comuns as reuniões em sua residência na Rua São Vicente de Paula, nas quais muito se conversava sobre arte e política. Além disso, tais oportunidades permitiram ao crítico conhecer mais profundamente os artistas sobre os quais escreveu. Muitos deles apontaram que as conversas com Schenberg foram extremamente produtivas e marcantes em sua trajetória artística.

Cabe dizer que até o ano de 1969 quando, por força do Ato Institucional $\mathrm{n}^{\circ}$ 5, foi aposentado compulsoriamente de seu cargo na Universidade de São Paulo, Mario Schenberg conciliava a atuação como cientista, a militância política e a crítica de arte. Somente após esse afastamento, passou a ter nessa última sua principal atividade ${ }^{38}$.

Ao integrar o Júri de Seleção da VIII Bienal, Mario Schenberg estava enfrentando diversos processos judiciais. Foi em meio a essa tensão que o crítico participou, no decorrer de maio de 1965, de algumas das reuniões para selecionar as obras que participariam da edição daquele ano.

Segundo o regulamento da VIII Bienal, o Júri de Seleção era composto por cinco membros, todos escolhidos pelos artistas. Tinham direito a voto apenas aqueles que já haviam participado de pelo menos uma bienal anterior. Cada um deles indicava dois nomes no ato de sua inscrição que, depositados numa urna, aguardavam o dia marcado para apuração ${ }^{39}$.

Em 27 de abril de 1965, foram conhecidos os nomes dos representantes dos artistas: José Geraldo Vieira (71 votos), Walter Zanini (64), Geraldo Ferraz (38), Fernando Lemos (33) e Mário Pedrosa (31). Em seguida, Sérgio Milliet (25) e Mario Schenberg (22), ficaram como suplentes $^{40}$. Em 30 de abril, Walter Zanini escreve à Diná Lopes Coelho, secretária da Fundação Bienal informando que viajaria para o Japão, a fim de participar do Júri de Seleção da Bienal de Tóquio, e não conseguiria retornar ao país a tempo de integrar o júri brasileiro ${ }^{41}$.

Conforme o regulamento, o crítico Sérgio Milliet foi chamado para substituí-lo, mas pôde comparecer apenas à primeira reunião do Júri, no Museu de Arte Moderna do Rio de Janeiro, em 06 de maio. Nas reuniões posteriores, Mario Schenberg esteve presente em seu

\footnotetext{
${ }^{38}$ OLIVEIRA, Alecsandra Matias de. Schenberg: crítica e criação. São Paulo: EDUSP, 2010.

${ }^{39}$ FUNDAÇÃO BIENAL. VIII Bienal. (catálogo de exposição) São Paulo: Fundação Bienal, 1965, p.20. Até a III Bienal, em 1955, a indicação dos dois nomes para o Júri era feita em espaço destinado a isso na própria ficha de inscrição. A partir da IV Bienal, a votação passou a ser feita em cédulas não identificadas, conforme descrito acima. (Arquivo Histórico Wanda Svevo, Fundação Bienal)

${ }^{40}$ ZANINI, Ivo. Indicado o Júri da VIII Bienal. Folha Ilustrada (São Paulo - Capital). 27/04/1965.

${ }^{41}$ Carta de Walter Zanini a Diná Coelho Lopes, de 30 de abril de 1961 (Arquivo Histórico Wanda Svevo, Fundação Bienal).
} 
$\operatorname{lugar}^{42}$. Tanto na ata final do Júri Nacional de Seleção, quando em nota divulgada à imprensa ao final dos trabalhos, é o nome de Mario Schenberg que consta no lugar do de Walter Zanini, como membro eleito pelos artistas ${ }^{43}$.

Uma vez integrando o Júri, Mario Schenberg não hesitou em defender os artistas com os quais mantinha contato, notadamente aqueles que estavam alinhados com tendências como as novas figurações, a saber, José Roberto Aguilar, Cláudio Tozzi e Rubens Guerchmann, entre outros; e a arte primitiva, como Waldomiro de Deus. Após a finalização dos trabalhos de seleção das obras para a VIII Bienal, Aracy Amaral traça um perfil das interações dos membros do Júri, na qual aponta Mário Pedrosa e Mario Schenberg como maiores definidores das escolhas feitas pelo grupo, no interior das discussões "tão comuns nesse tipo de Seleção"44.

O crítico, contudo, não pôde comparecer à inauguração da VIII Bienal de São Paulo em 4 de setembro, pois estava preso. O Congresso Internacional de Partículas Elementares se aproximava: Mario Schenberg não tinha obtido permissão para viajar ao Japão e estava com prisão preventiva decretada há meses. O Professor Schenberg foi libertado pouco tempo depois e conseguiu embarcar devido, em grande parte, à solidariedade da comunidade científica nacional e internacional, que fez chegar ao governo do país inúmeras mensagens pedindo sua libertação ${ }^{45}$.

Também os artistas manifestaram seu apoio: na inauguração da VIII Bienal, após a cerimônia de premiação, os artistas Maria Bonomi e Sérgio Camargo (ambos premiados naquela edição) foram ao encontro do presidente da república, o militar Castelo Branco, e entregaram a ele uma carta que ficou conhecida como Manifesto dos 4. Este documento, assinado por vários artistas, continha o pedido para que o presidente intercedesse em favor de

\footnotetext{
${ }^{42}$ Sérgio Milliet teve de ser substituído às vésperas de viajar ao Rio de Janeiro para o prosseguimento dos trabalhos do Júri devido a um mal-estar. (Schenberg em Vez de Milliet. Correio da Manhã (Estado da Guanabara). 07/05/1965).

${ }^{43}$ Em 19 de maio, Francisco Matarazzo Sobrinho envia a Vasco Mariz, chefe da divisão de difusão cultural da Fundação Bienal, a lista de artistas que foram aceitos na oitava edição do evento, na qual constava a composição final do Júri de Seleção (Arquivo Histórico Wanda Svevo, Fundação Bienal).

44 "O trabalho do Júri, além de difícil, duro e intenso, foi marcado por discussões tão comuns nesse tipo de seleção. Mario Pedrosa e Mario Schenberg, ao que tudo indica, definiam as escolhas, parece ter havido pouca identidade de pontos de vista entre Geraldo Ferraz e Fernando Lemos. José Geraldo Vieira, como sempre, atuou como poder moderador" (AMARAL, Aracy. Terminada a Seleção da Bienal. A Gazeta, São Paulo (capital), 18/05/1965).

${ }^{45}$ Resta saber com mais detalhes como foi possível a Mario Schenberg participar das diversas reuniões do Júri sob ameaça de prisão. Isso, contudo, não pôde ser realizado durante o andamento desta pesquisa, devido às limitações de tempo e ao assunto delimitado.
} 
Mario Schenberg, Florestan Fernandes, João Cruz Costa e Fernando Henrique Cardoso, docentes da Faculdade de Filosofia, Ciências e Letras da Universidade de São Paulo ${ }^{46}$.

${ }^{46} \mathrm{O}$ texto integral do Manifesto dos 4 foi incluído entre os Anexos deste estudo. 


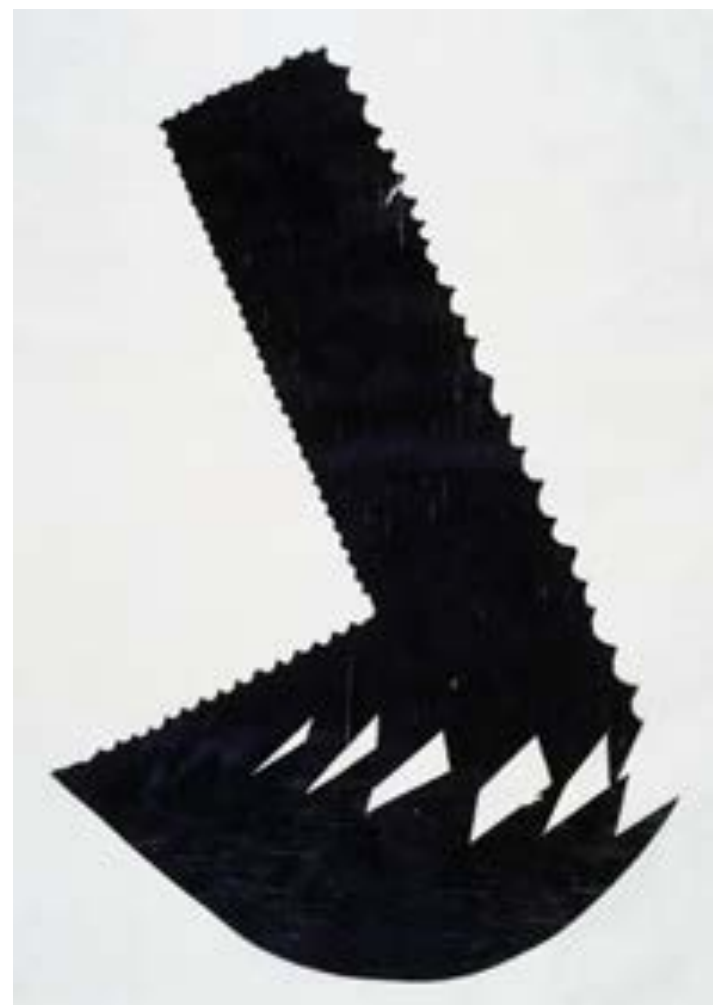

Figura 5 - Maria Bonomi, 1965, xilogravura sobre papel de arroz, $130 \times 108$. A artista ganhou o prêmio de melhor gravadora nacional.

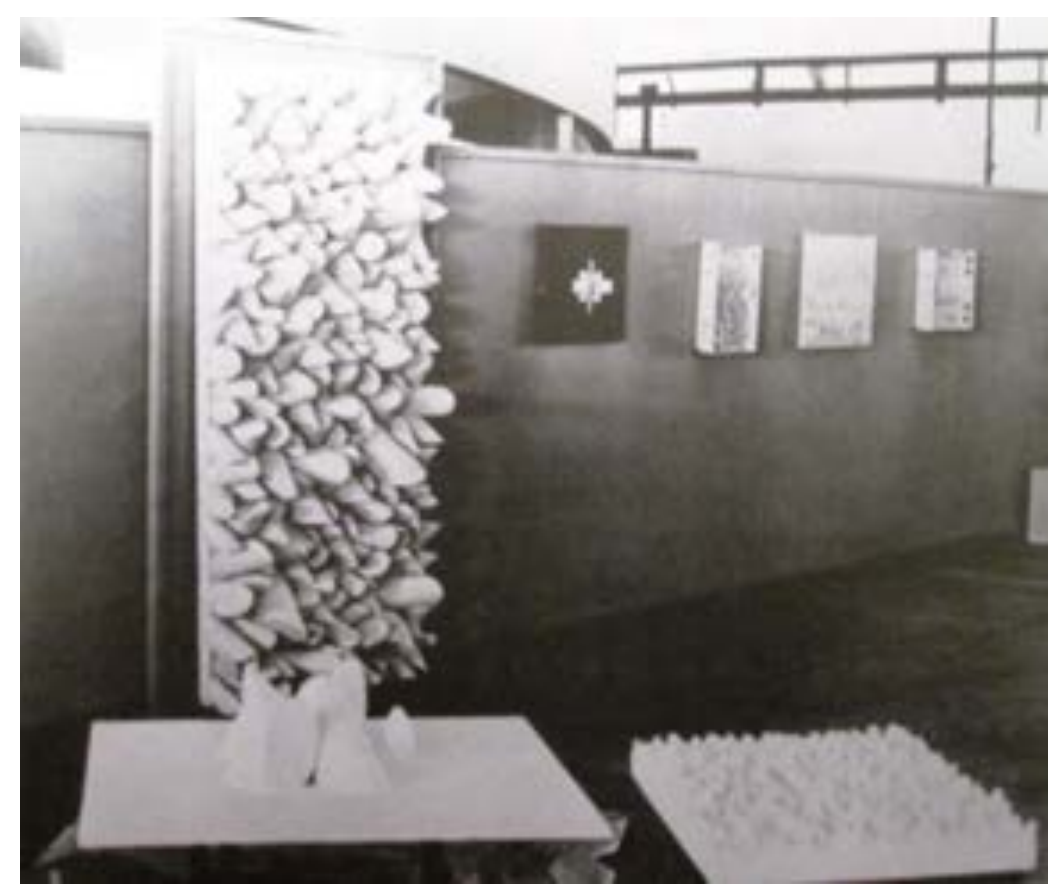

Figura 4 - Sala de Sérgio Camargo, VIII Bienal de São Paulo. O artista recebeu o prêmio de melhor escultor nacional na edição. 
1967: A Bienal do Pop

Momento final de um período de efervescência cultural no país, 1967 foi o ano de Terra em Transe, O Rei da vela, da exposição Nova Objetividade Brasileira, assim como de Tropicália, o ambiente de Hélio Oiticica e da explosão do tropicalismo na música, manifestações que marcaram os anos de $1960^{47}$. Cinema, teatro, música e artes plásticas manifestavam o anseio de dar uma contribuição original à esfera da cultura, seja em nível nacional, seja internacional. O crescendum dessa movimentação, iniciado na década de 1950 e perturbado com o golpe de 1964, seguiria até a decretação do AI-5, quatro anos depois.

Em 1967, a Pop $\mathrm{Art}^{48}$ norte-americana, que marcou presença na Bienal anterior, deu o tom da mostra. Não foi por acaso que a IX Bienal ficou conhecida como a Bienal do Pop. Apesar da repercussão da sala dos Estados Unidos ter sido significativa, outros países também trouxeram para a Bienal desdobramentos da Pop Art ${ }^{49}$.

Assim como na Bienal anterior, a representação brasileira foi criticada pela heterogeneidade dos trabalhos selecionados, bem como pelo grande número de artistas. Foi, nas palavras de Leonor Amarante, uma Bienal "generosa, que tinha de tudo um pouco, sem

${ }^{47}$ FAVERATO, Celso. A outra América. Folha de São Paulo, 09 de junho de 2001. Terra em Transe: filme de 1967, com direção de Glauber Rocha. O Rei da Vela: peça escrita por Oswald de Andrade em 1933, cuja montagem dirigida e encenada por José Celso Martins Corrêa junto ao Teatro Oficina em 1967 ficou conhecida internacionalmente. Nova Objetividade Brasileira: exposição realizada em abril de 1967 no MAM-RJ, com participação de diversos artistas e críticos, em torno da ideia de "nova objetividade", que começou a ser delineada por Hélio Oiticica na exposição-seminário Propostas 65, reconhecendo a contribuição de Mario Schenberg em sua formulação. Tropicália: ambiente elaborado por Hélio Oiticica, composto por um labirinto no qual estavam dois Penetráveis - PN2, 1966, Pureza é um Mito e PN3, 1966/1967, Imagético - junto a plantas, areia, poemas-objeto, capas de parangolé e um aparelho de televisão. (ITAÚ CULTURAL. Enciclopédia de Artes Visuais Itaú Cultural. Disponível em: www.itaucultural.org.br Acesso em 09/05/2013).

48 Tendo surgido na Inglaterra nos anos 50, "mas polarizada e difundida pelos norte-americanos, a partir de 1962", a Arte Pop se consolidou "como uma "tela de fundo" poderosa à qual se remetiam como ressonâncias a maioria das manifestações figurativas e realistas dessa época" (Cf. PECCININI, Daisy. Figurações no Brasil: anos 60. In: Projeto Visitando o MAC na Web). Na Europa, essa vertente marcou presença com o Novo Realismo. Alguns elementos precursores do Pop, ainda no fim dos anos 50 foram, segundo Archer, "o interesse pelo corriqueiro, a disposição de abarcar o acaso (não apenas por uma herança do Dadaísmo, mas também o reconhecimento de que na vida as coisas simplesmente acontecem) e um novo senso visual" (ARCHER, Michael. Arte Contemporânea. São Paulo: Martins Fontes, 2008,, p. 5). A noção de assemblage, proveniente do Dadaísmo, teve desdobramentos na Arte Pop: tanto pelo fato de se retirar imagens e objetos de seu lugar no mundo comum, reorganizando-os na obra de arte, quanto pelo fato de que "essa conexão com o cotidiano, desde que não nos envergonhemos dela, deixa o caminho livre para uma vasta gama de materiais e técnicas até (...) o momento não associados ao fazer artístico" (ARCHER, Idem, Ibidem, p. 4). O “caminho livre” em potencial, aberto por essa nova sensibilidade, já bastante perceptível por volta de 1962, nas obras de artistas como Roy Lichtenstein, Andy Warhol, Claes Oldenburg, Tom Wesselman e James Rosenquist (ARCHER, Idem, Ibidem, p. 6), na medida em que as imagens e materiais provenientes da cultura visual de massas nos Estados Unidos eram a matéria-prima constante.

49 AMARANTE, Leonor. As Bienais de São Paulo: 1951 a 1987. São Paulo: Projeto, 1989, p. 161. Um dos destaques da representação dos Estados Unidos foi a sala especial dedicada ao pintor Edward Hopper, falecido cinco messes antes da exposição e, então, recentemente reconhecido como precursor da Pop Art. (Idem, Ibidem, p. 167). 
rigor conceitual" ${ }^{, 50}$. Três anos mais tarde, Mario Pedrosa manifestaria sua discordância em relação à constituição das salas brasileiras, "para as quais um júri da seleção de missionário, sob a ascendência de Mário Schenberg, deixou passar tudo, o bom e o mau, o achado e o inacabado, bastando para tanto que um embrião de idéia despontasse" ${ }^{\text {" }}$. Contudo, havia nesse conjunto artistas jovens cuja qualidade era já então reconhecida, a saber, Wesley Duke Lee, Carlos Vergara, Nelson Leirner, José Roberto Aguilar, Cláudio Tozzi, Flávio de Carvalho, Marcelo Nietsche, José Resende, Frans Weissemann, Fayga Ostrower e Maria Bonomi.

No texto A Representação Brasileira na IX Bienal de São Paulo, Schenberg afirmou que o júri foi capaz de compreender que "o momento atual da arte brasileira se caracteriza por uma irrupção maciça de artistas jovens que encontram novos caminhos" ${ }^{2}$, refletindo com propriedade a extrema variedade de direcionamentos tomados pelos novos artistas e pelas novas tendências realistas. Observou, ainda, que a presença de objetos e esculturas foi maior que na bienal anterior, tanto pela orientação diferenciada do júri de seleção, quanto pelo aumento das pesquisas de artistas nessa direção ${ }^{53}$.

Foi singular na história das bienais a intensidade da participação do público, que nessa edição foi como nunca antes, e não se repetiria nas mostras posteriores. A IX Bienal foi a única em que se permitiu tocar nas obras, em que houve participação do público, até mesmo em relação às obras que não tinham essa proposta. Leonor Amarante comenta que, dias depois da abertura da mostra, não se encontrava nenhuma obra intacta. “As engrenagens estavam quebradas, máquinas e motores fora de uso, interruptores e lâmpadas queimados, equipamentos de som mudos" ${ }^{, 54}$. Para Mario Pedrosa, a quem a participação do público agradou, isso era um sinal de que "o povo consagra a arte nova" 55 . O crítico observa que, na Bienal de 1967, o público compreendeu que a arte estava passando por uma profunda transformação, tornando-se algo diferente do que foi visto nas primeiras edições ${ }^{56}$.

Outra novidade foi a unificação dos prêmios: conforme um acordo assinado entre a Fundação Bienal e o Itamaraty, não haveria mais separação entre as premiações nacionais e

${ }^{50}$ AMARANTE, Leonor. As Bienais de São Paulo: 1951 a 1987. São Paulo: Projeto, 1989, p. 168.

${ }^{51}$ PEDROSA, Mário. A Bienal de Cá para Lá. In Mundo, Homem, Arte em crise. (Org. Aracy Amaral). São Paulo: Perspectiva, 1975, p. 301.

${ }^{52}$ SCHENBERG, Mario. A Representação Brasileira na IX Bienal de São Paulo. In Pensando a Arte. São Paulo: Nova Stella, 1988, p. 183.

${ }^{53}$ SCHENBERG, Mario. A Representação Brasileira na IX Bienal de São Paulo. In Pensando a Arte. São Paulo: Nova Stella, 1988, p. 183.

${ }^{54}$ AMARANTE, Leonor. As Bienais de São Paulo: 1951 a 1987. São Paulo: Projeto, 1989, p. 154.

${ }^{55}$ PEDROSA, Mário. A Bienal de Cá para Lá. In Mundo, Homem, Arte em crise. (Org. Aracy Amaral). São Paulo: Perspectiva, 1975, p. 301. Cf. também A Bienal e a participação...do povo, no mesmo livro.

${ }^{56}$ PEDrosA, Mário. A Bienal de Cá para Lá. In Mundo, Homem, Arte em crise. (Org. Aracy Amaral). São Paulo: Perspectiva, 1975, p. 300. 
internacionais ${ }^{57}$. Essa mudança pode ser vista como uma resposta ao momento de crise pelo qual passava a mostra, desde o Golpe Militar de 1964, que trouxe, em seu bojo, a censura. Conforme já foi apontado, não eram novidade as críticas ao sistema organizacional das bienais e, também por isso, as circunstâncias pediam mudanças.

A IX Bienal teve lugar entre 22 de setembro de 1967 e adentrou em 1968, indo até 8 de janeiro. Foi uma edição de grandes proporções, trazendo 956 artistas de 63 países, somando 4.338 obras expostas ${ }^{58}$. Tais dimensões, sobretudo relativas à representação brasileira (366 artistas, entre os quais contavam 253 estreantes), foram um dos aspectos criticados nessa edição. Critica essa, que já era tecida desde as primeiras bienais.

Esta foi a última edição do evento antes do Ato Institucional Número 5, decretado no fim de 1968 e que, no ano seguinte, causaria estragos à vida cultural do país. Antes mesmo da inauguração da mostra, algumas obras foram retiradas pelos militares, por terem-nas julgado ofensivas. Alguns jornalistas foram impedidos de circular livremente pela Bienal. É interessante notar que, enquanto a obra Políptico móvel gênese do pavilhão nacional do artista Quissak Júnior, foi censurada por ter retrabalhado a bandeira nacional, símbolo então vetado para uso popular pelo governo; a obra Três Bandeiras, de Jasper Johns, que sobrepunha imagens da bandeira norte-americana, foi premiada ${ }^{59}$.

\footnotetext{
${ }^{57}$ AMARANTE, Leonor. As Bienais de São Paulo: 1951 a 1987. São Paulo: Projeto, 1989, p. 171.

${ }^{58}$ FUNDAÇÃO BIENAL. Bienal a Bienal. Disponível em: http:/www.bienal.org.br/FBSP/pt/AHWS/BienalaBienal/Paginas/6BienalSaoPaulo.aspx?selected=6 Acesso em 15/01/2013.

${ }^{59}$ AMARANTE, Leonor. As Bienais de São Paulo: 1951 a 1987. São Paulo: Projeto, 1989, p. 157.
} 


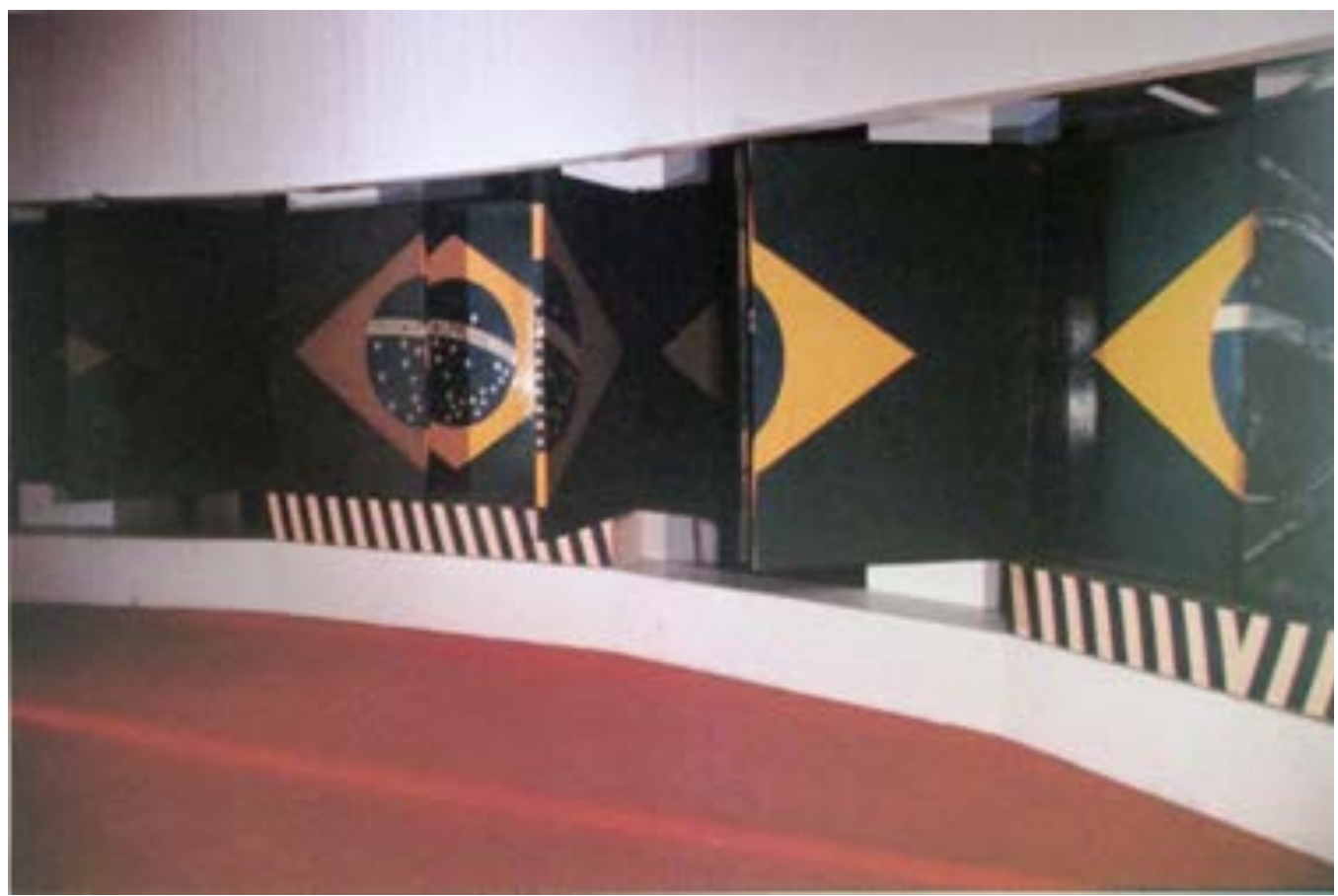

Figura 7 - Quissak Júnior, Políptico Móvel Um ou do Campo Verde, Políptico Móvel Dois ou do Losango Amarelo, Políptico Móvel Três ou do Círculo Azul, Políptico Móvel Quatro ou da Faixa Branca, Políptico Móvel Cinco ou da Pátria. 1967, óleo sobre tela.

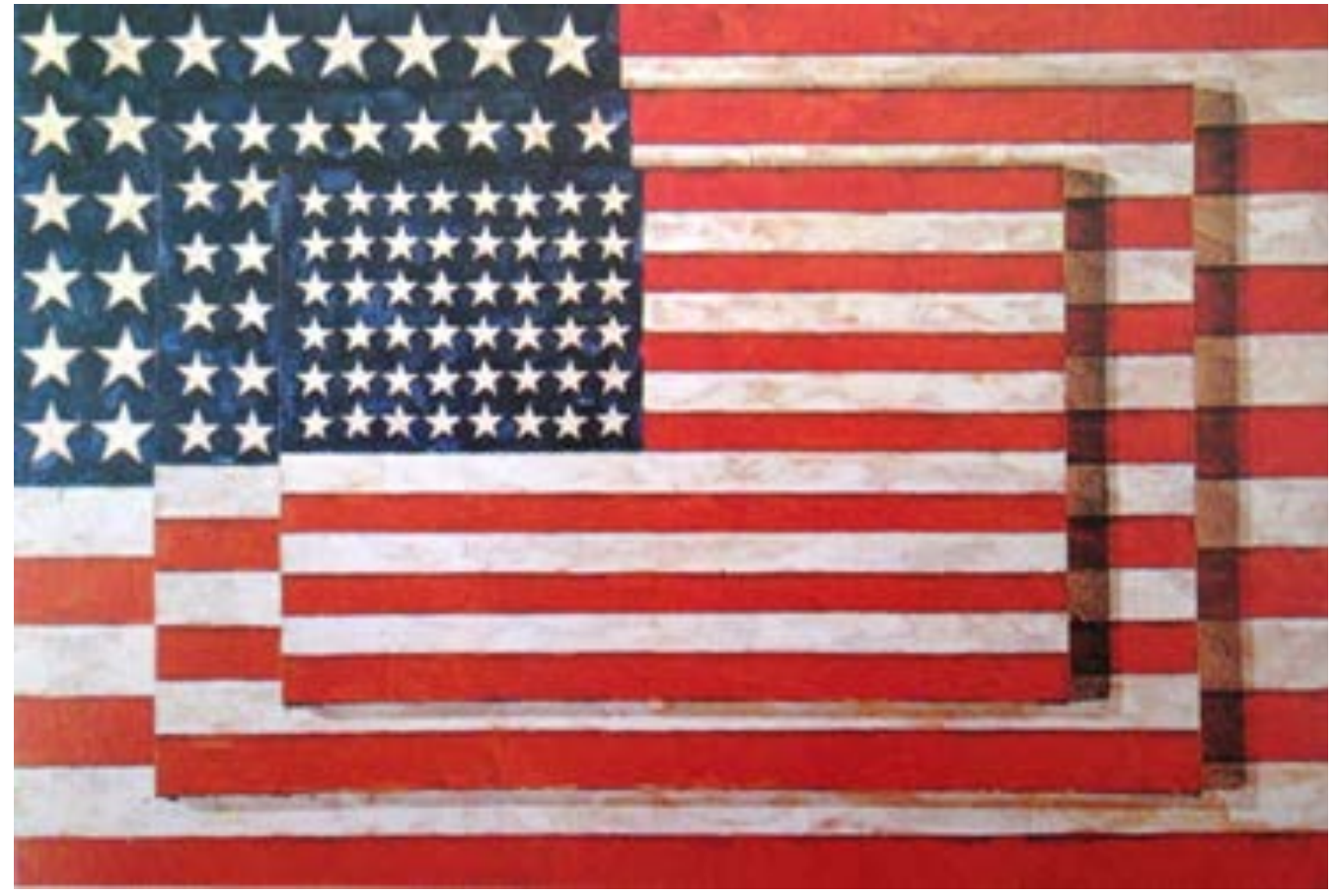

Figura 6 - Jasper Johns, Três Bandeiras, 1958. 
O Júri de Seleção da IX Bienal de São Paulo foi constituído por dois nomes indicados pela Diretoria Executiva da Fundação Bienal, dois escolhidos pelos artistas por meio de votação e um quinto, escolhido por esses quatro. Novamente, o direito a voto cabia apenas aos artistas que já tinham sido aceitos em pelo menos uma Bienal anterior. Cada um deles deveria indicar, no ato da inscrição, dois nomes de críticos de arte, em ficha fornecida pela Bienal ${ }^{60}$. A apuração não sofreu mudanças em relação à edição anterior. Assim, o corpo de jurados foi integrado por: José Geraldo Vieira e Mario Schenberg (eleitos pelos artistas, aquele com 41 votos, esse com 32 $)^{61}$, Geraldo Ferraz e Jayme Maurício (indicados pela Fundação Bienal), Clarival Valadares (escolhido pelos quatro).

Diferente do regulamento da edição anterior, no qual eram elegíveis não apenas críticos de arte, mas também artistas (Regulamento da VIII Bienal, Art. $5^{\circ}$ ), na IX Bienal apenas críticos de arte poderiam ser votados para integrar o Júri de Seleção (Regulamento da IX Bienal, Art. $4^{\circ}$ ). Na edição seguinte, em 1969, seria ainda mais enfatizada a exigência de que todos os membros do Júri deveriam ser críticos de arte, na medida em que essa informação foi destacada num subitem exclusivo a esse respeito (conforme o Regulamento da X Bienal, Capítulo II, item V, subitem $a)^{62}$.

Se por um lado, as mudanças na conformação do Júri de Seleção, expressas nas sucessivas alterações dos regulamentos, enfatizam a posição de que as obras inscritas pelos artistas seriam julgadas com mais propriedade por críticos de arte que por outros artistas; por outro, em nenhum momento a Fundação Bienal define o que entende por crítico de arte.

É a partir dessa indefinição que surge a polêmica em torno da aceitação de Mario Schenberg como membro do Júri de Seleção nas edições das quais participou, pois apesar de ser considerado como tal pelos artistas, seu nome foi recebido com dúvidas pela Fundação Bienal. Na ocasião, Luíz Rodrigues Alves, então diretor da Bienal, fez restrições à indicação do professor Schenberg, devido ao fato de ele não assinar nenhuma coluna em jornal, e também por conta de sua situação política, posição que desmentiu logo em seguida, tendo sido respeitado o resultado da eleição ${ }^{63}$.

De fato, o incidente com relação à eleição de Mario Schenberg trouxe à tona essa demanda que há tempos era feita por artistas e críticos. A tentativa de definir como crítico de

\footnotetext{
${ }^{60}$ FUNDAÇÃO BIENAL. IX Bienal. (catálogo de exposição) São Paulo: Fundação Bienal, 1967, s.p.

${ }^{61}$ MAURÍCIO, Jayme. Bienal: eleitos dos artistas. Correio da Manhã, 06/06/67.

${ }^{62}$ FUNDAÇÃO BIENAL. VIII Bienal. (catálogo de exposição) São Paulo: Fundação Bienal, 1965, Regulamento: Capítulo II, Artigo $5^{\circ}$, p.20. FUNDAÇÃO BIENAL. IX Bienal. (catálogo de exposição) São Paulo: Fundação Bienal, 1967. Regulamento: Capítulo II, Artigo 4º s.p. FUNDAÇÃO BIENAL. X Bienal. (catálogo de exposição) São Paulo: Fundação Bienal,1969. Regulamento: Capítulo II, V, a, p. 449.

${ }^{63}$ Schenberg fica. Correio da Manhã, 06/06/67.
} 
arte o profissional que mantinha colunas em jornais, contudo, não pareceu ter caído muito bem nesse caso, conforme ficou evidente pelo posicionamento dos artistas presentes na apuração dos votos, que saíram em defesa do crítico $^{64}$. Sobre isso, o próprio Schenberg ${ }^{65}$ diria anos mais tarde:

\begin{abstract}
Eu, que já tinha organizado a primeira exposição de Volpi em 1944, organizei em 61 a sua primeira retrospectiva. Depois disso, começaram a votar para que eu fizesse parte dos júris de seleção das Bienais. O primeiro júri que integrei foi em 1965, depois 67 e 69. E, a partir daí, a Bienal me aplica o Ato 75. Mas antes disso, já em 67 , ganhei a eleição por maioria e quiseram me impugnar, alegando que eu não era crítico de arte, que não escrevia em jornal, coisa de que, aliás, nunca gostei. Sempre preferi escrever esporadicamente. Mas, finalmente, tiveram que recuar, porque fui aceito pela Associação dos Críticos de Arte. Também a Associação de Artistas Plásticos firmou posição a meu favor.
\end{abstract}

A participação de Schenberg nas Bienais se deu por força de sua atuação junto aos artistas, os quais confiavam em sua atuação e acreditavam que ele poderia defender seus interesses junto ao júri do evento ${ }^{66}$. Da parte da maioria de outros críticos, ele se deparava com o preconceito, em parte devido à sua formação e metodologia peculiar, em parte devido ao seu posicionamento político.

Segundo afirma a pesquisadora Alecsandra Matias de Oliveira em Schenberg: Crítica e Criação, os lugares de divulgação da arte, para o crítico, eram os meios especializados, como galerias, catálogos e álbuns de artistas, além do ambiente universitário. Schenberg não tinha acesso a jornais e revistas: sendo físico, era objeto de preconceito por parte dos demais críticos de arte, geralmente literatos ou ligados às ciências humanas. Além disso, se outros críticos de arte mantinham seu posicionamento político de modo a não prejudicar seu relacionamento com a imprensa, as ideias de Schenberg, em sua especificidade, não eram vistas como passíveis de veiculação periódica, pois o físico era um “incontrolável marxista, mesmo para os colegas de doutrina" ${ }^{\circ 7}$.

Retomando: um dos motivos para a tentativa de impugnar sua participação no Júri das bienais foi a alegação de que ele não escrevia em jornais. É possível constatar que Mario Schenberg não concordava com esse requisito, pois não o via como condição necessária (nem suficiente) para o exercício da critica de arte. Se o que conferia a alguém a competência para tal atividade era a formação teórica adequada, então era perfeitamente possível que houvesse críticos que não escrevessem em jornais e, principalmente, que houvesse pessoas que

${ }^{64}$ Artistas a favor do crítico, s/p, s/d, sem identificação de jornal.

${ }^{65}$ SCHENBERG, Mario. Depoimento. In AJZNBERG, Elza. Schenberg - Arte e Ciência. São Paulo: ECA/USP, 1995, p. 142.

${ }^{66}$ OLIVEIRA, Alecsandra Matias de. Schenberg: crítica e criação. São Paulo: EDUSP, 2010.

${ }^{67}$ OLIVEIRA, Alecsandra Matias de. Schenberg: crítica e criação. São Paulo: EDUSP, 2010, p. 83-4. 
escrevessem em jornais sem ter a competência para tanto. A esse respeito, Schenberg ${ }^{68}$ afirmou o seguinte:

\begin{abstract}
Aqui no Brasil, as exigências em relação ao crítico de arte são muito pequenas, de modo que qualquer pessoa que tenha algumas ideias sobre arte, algumas experiências de arte, já é considerado um crítico. Mas acho necessário superar esse período, eu acho necessário haver uma crítica de arte baseada em outros critérios que não seja simplesmente o de escrever em jornais.
\end{abstract}

Schenberg não se considerava um crítico de arte, pois não julgava ter o embasamento necessário a tal atividade, uma vez que seus estudos sobre Filosofia e Teoria da Arte tinham se dado esporadicamente, por meio de leituras motivadas pela curiosidade: "Nunca me coloquei como crítico de arte, outros é que disseram que eu era [...]" ${ }^{, 69}$. Enquanto acadêmico, dava muita importância à formação teórica requerida para tanto e, como sua aproximação com a arte foi menos disciplinada que com a ciência, não considerava ter o embasamento que julgava necessário ao exercício da crítica de $\operatorname{arte}^{70}$.

É claro que nem todos os críticos da época se enquadravam na objeção feita por Schenberg à ideia pré-concebida de que manter colunas em jornais fazia de alguém crítico de arte. Mas pode-se ver que, em seu entender, essa concepção corrente do crítico de arte era prejudicial ao desenvolvimento da arte no país.

Outra movimentação da organização da IX Bienal foi o projeto das pré-bienais, ou seja, bienais nacionais que aconteceriam nos anos pares, com a finalidade de selecionar melhor a representação brasileira a ser levada para as bienais internacionais ${ }^{71}$. Em setembro de 1970, seria inaugurada a primeira Bienal Nacional, que teve o mérito de ir além do eixo Rio-São Paulo, reunindo artistas de 19 estados do país. O evento teria outras edições: em 1972, 1974 e 1976. Em 1978, foi substituído pela Bienal Latino-Americana que, apesar de projetada para ser sazonal, teve apenas uma edição ${ }^{72}$.

Pode-se dizer que ideia da Pré-Bienal se colocava como resposta às críticas ao gigantismo da representação brasileira, tecidas desde as primeiras bienais. Em lugar de expor um número reduzido de trabalhos de inúmeros artistas, a seleção por meio das pré-bienais

68 SCHENBERG, Mario. Entrevista com Mário Schenberg. (Publicada originalmente na Revista Trans/Form/Ação, v. 3, p. 6-62, 1980). In Trans/Form/Ação. Marília, v.34, 2011. Edição Especial, p. 155.

69 SCHENBERG, Mario. Entrevista com Mário Schenberg. (Publicada originalmente na Revista Trans/Form/Ação, v. 3, p. 6-62, 1980). In Trans/Form/Ação. Marília, v.34, 2011. Edição Especial, p. 154.

${ }^{70}$ GOLDFARB, José Luiz. Voar também é com os Homens. São Paulo: EDUSP, 1994, p. 127.

${ }^{71}$ Foi encontrado o rascunho do regulamento do que seria a mostra Plástica 69, a ser realizada no primeiro semestre do ano que lhe dá nome, já com a configuração das bienais nacionais, cujo início se daria apenas em 1970. (Arquivo Histórico Wanda Svevo, Fundação Bienal).

${ }^{72}$ AMARANTE, Leonor. As Bienais de São Paulo: 1951 a 1987. São Paulo: Projeto, 1989. 
objetivava mudar esse padrão, selecionando menos artistas, mas exibindo um conjunto de obras amplo o suficiente para dar a ver a trajetória da pesquisa de cada um deles.

Com relação a isso, é importante observar que Mario Schenberg foi contrário ao novo sistema de seleção pelas pré-bienais, pois isso dificultaria a participação de novos artistas nas bienais internacionais. Segundo Schenberg ${ }^{73}$,

[c]om uma seleção de trabalhos, feita pela pré-Bienal, somente os artistas já consagrados acabariam participando da Bienal Internacional. Ninguém teria a coragem de excluir obras de artistas experientes e renomados para colocar em seu lugar um desconhecido, mesmo que o trabalho seja melhor.

Essa citação, feita por Leonor Amarante no livro As Bienais de São Paulo: 1951 a 1987, constitui a única pista a respeito do posicionamento do crítico sobre as pré-bienais até o momento. Mas é possível perceber que está alinhada com o incentivo que Mario Schenberg dedicou aos artistas jovens, como foi próprio de sua atuação enquanto crítico de arte, principalmente nos anos de 1960 e 1970. Ao escrever sobre a IX Bienal de São Paulo, o crítico afirmou que "o maior mérito do júri da seleção [...] foi ter compreendido o momento revolucionário atual da arte brasileira e de ter dado prioridade às inovações, mesmo quando apresentadas em obras com deficiências de execução"74.

O crítico destacou, ainda, a relevância da compreensão de que a qualidade dizia respeito à "riqueza de concepção experimental e de intuição pioneira", e não simplesmente à dimensão artesanal do acabamento da obra de arte. Nesse sentido, as obras selecionadas para a IX Bienal de São Paulo, segundo Schenberg, teriam dado uma "imagem impressionante da vitalidade do movimento artístico brasileiro atual” ${ }^{, 75}$.

\footnotetext{
${ }^{73}$ Depoimento de Mario Schenberg, apud AMARANTE, Leonor. As Bienais de São Paulo: 1951 a 1987. São Paulo: Projeto, 1989, p 179. É importante esclarecer que, no decorrer desta pesquisa, nenhuma outra fonte foi encontrada a respeito da opinião de Mario Schenberg sobre a criação das pré-bienais. Apesar do esforço realizado no sentido de localizar fontes primárias, a única pista a esse respeito, até o momento, continua sendo o livro citado que, por não ter natureza acadêmica - o que de modo algum quer dizer que não seja uma publicação séria e confiável - não apresenta diretamente a referência de sua citação. Além disso, é possível que, por ter vivenciado tais acontecimentos, a autora estivesse citando o crítico a partir de suas memórias.

${ }^{74}$ SCHENBERG, Mario. Pensando a Arte, São Paulo: Nova Stella, 1988, p. 194.

${ }^{75}$ SCHENBERG, Mario. Pensando a Arte, São Paulo: Nova Stella, 1988, p. 196.
} 
As deficiências de execução foram atribuídas à grande quantidade de artistas jovens entre os participantes da exposição. Contudo, a juventude, e até a "inexperiência", foram vistas justamente como um dos impulsos dos artistas na direção de novos caminhos: em nome da inovação das propostas que apresentam, Schenberg relevou tais falhas. Isso porque, para ele, a diversidade de artistas e de suas pesquisas era muito animadora.

O motivo para isso foi a ênfase dada à proposta, ao conceito apresentado pelo artista, e não apenas à obra de arte em seu aspecto técnico de execução. Seu valor formal intrínseco, enquanto princípio interno, não era mais o foco

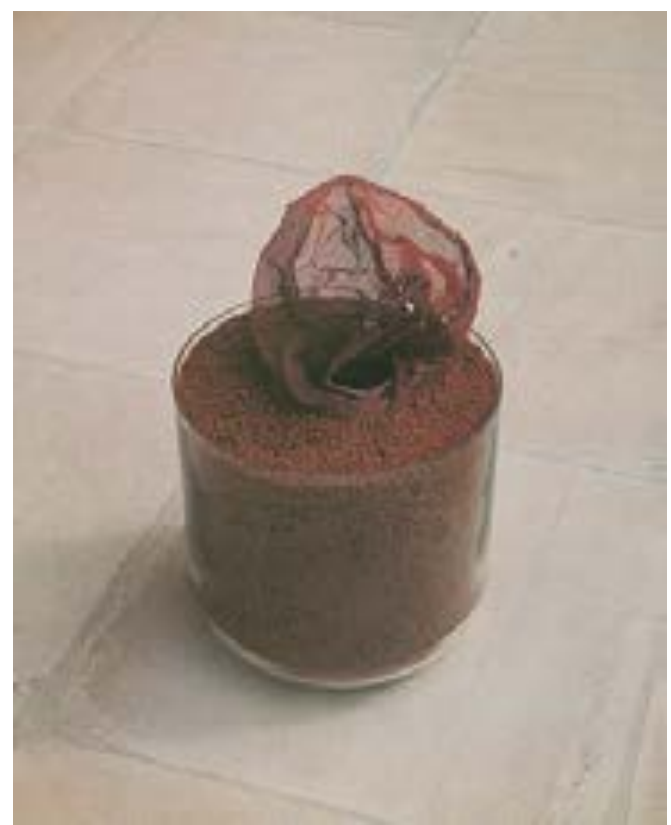

Figura 8 - Hélio Oiticica, B15 Bólide Vidro 4 - Terra, 1964, cuba de vidro, terra e tecido. Projeto Helio Oiticica (Rio de Janeiro, RJ). Reprodução fotográfica autoria desconhecida. da análise crítica, mas a intencionalidade da poética e da proposição que o cercava e lhe atribuía sentido. O questionamento artístico, social ou político presente na obra passou a fazer parte de sua conformação, e seu fundamento se localiza além dela, na linguagem ${ }^{76}$.

Diante disso, apesar das poucas pistas obtidas, pode-se supor o motivo pelo qual, para Mario Schenberg, a realização de uma bienal nacional, ou pré-bienal, seria prejudicial ao próprio intento da mostra: apresentar as tendências mais recentes das artes plásticas. Quanto mais etapas fossem interpostas entre o artista iniciante e a Bienal de Arte de São Paulo, mais difícil seria para ele vencer o renome de seus colegas com carreiras já consolidadas.

\footnotetext{
${ }^{76}$ Daí decorre a importância dos textos escritos pelos artistas, que se tornaram comuns a partir da década de 1960, na medida em que mostravam os fundamentos conceituais das obras e tornavam claros os questionamentos por elas apresentados. Alguns dos artistas que fizeram isso com frequência foram Hélio Oiticica, Lygia Clark, Waldemar Cordeiro e Frederico Morais (sendo que os dois últimos atuavam também como críticos de arte). Cf. FERREIRA, Glória \& COTRIM, Cecília (seleção e comentários). Escritos de artistas: anos 60/70. Tradução de Pedro Süssekind... et al. - 2. Ed. - Rio de Janeiro: Jorge Zahar Ed., 2009. Na Mesa Redonda de críticos de arte promovida na XI Bienal, em 1971, Mario Schenberg fará considerações importantes sobre o assunto, chamando a atenção da Fundação Bienal para as mudanças profundas ocorridas na arte durante a década de 1960. Mudanças essas que não excluíam as técnicas chamadas tradicionais, mas demandavam a atualização da organização das bienais que, em seu entender, não estava acompanhando essas transformações (Arquivo Wanda Svevo, Fundação Bienal).
} 


\section{9: Boicote à Bienal}

No fim de 1968, sobreveio o endurecimento da censura. Tendo repercutido em diversas instituições públicas federais, estaduais e municipais, o decreto atingiu, no início do ano seguinte, vários professores e funcionários da Universidade de São Paulo, que foram demitidos ou aposentados compulsoriamente em abril de 1969 (meses depois de o A I - 5 ter sido decretado, em 13 de dezembro de 1968), restringindo atividades políticas e manifestações culturais ${ }^{77}$. Entre eles estava o Professor Mario Schenberg que, a partir de então passou a dedicar mais tempo à crítica de arte, uma vez que foi impedido até mesmo de frequentar bibliotecas e ambientes universitários.

Marcada pelo boicote internacional, ao qual aderiram artistas, críticos de arte e intelectuais, todas as fases da realização da X Bienal foram marcadas por dificuldades que, com maior ou menor êxito, foram contornadas pela Comissão Técnica e pelo Júri de Seleção, que organizou várias salas especiais, além da sala geral da representação brasileira.

A mostra teve lugar entre 27 de setembro e 14 de dezembro de 1969. A comissão de técnica de artes plásticas foi integrada por Aracy Amaral, Edyla Mangabeira Unger, Frederico Nasser, Mário Barata, Waldemar Cordeiro e Wolfgang Pfeiffer ${ }^{78}$. Participaram da X Bienal de São Paulo 446 artistas provenientes de 53 países, exibindo 2.572 obras. Diante do movimento internacional de boicote à Bienal, o número de artistas participantes caiu pela metade, se comparado à edição anterior. Esse período de baixa da bienal se agravaria ainda mais no ano seguinte.

Toda a segmentação cultural do país ressentia-se da censura que, não ocorrendo apenas nas bienais, alcançava diversas outras exposições, das quais eram retiradas quaisquer obras consideradas ofensivas ao regime militar. No mesmo ano, ocorreu a invasão e o fechamento da exposição que apresentaria os trabalhos dos artistas que participariam da VI Bienal dos Jovens de Paris (no MAM do Rio de Janeiro), antes mesmo de sua inauguração ${ }^{79}$.

Essa foi a causa imediata do movimento de boicote à X Bienal de São Paulo, catalisando a revolta perante a situação incômoda em que se encontrava o país por parte de artistas, críticos e intelectuais. Some-se a isso o fato de que, também nessa mostra, a retirada

\footnotetext{
${ }^{77}$ Folha registrou trajetória de FHC, da USP à Presidência. Jornal Folha de São Paulo, 18 de junho de 2011.

${ }^{78}$ FUNDAÇÃO BIENAL. Bienal a Bienal. Disponível em:

http://www.bienal.org.br/FBSP/pt/AHWS/BienalaBienal/Paginas/6BienalSaoPaulo.aspx?selected=6 Acesso em 15/01/2013.

${ }^{79}$ AMARANTE, Leonor. As Bienais de São Paulo: 1951 a 1987. São Paulo: Projeto, 1989.
} 
de inúmeras obras pela polícia antes mesmo de sua inauguração, não tendo despertado protestos da Fundação Bienal, pôs fim à esperança de que ela se tornasse um polo de resistência ao autoritarismo ${ }^{80}$.

Outro aspecto dessa situação era o fato de que, sendo a Fundação Bienal subvencionada por verbas estaduais e municipais, dependia do governo para levar à cabo suas atividades. Francisco Alambert \& Polyana Canhête ${ }^{81}$ observam que isso levava a Bienal a ser vista como evento oficial e, portanto, aderida ao status quo do regime militar. Nesse sentido, ao se recusarem a participar dela, artistas, críticos de arte e intelectuais endereçavam ao governo instaurado no país sua manifestação de repúdio.

Mário Pedrosa, então presidente da Associação Brasileira de Críticos de Arte (ABCA), foi quem deu início ao movimento pelo boicote, protestando violentamente "contra a censura do Itamaraty às obras selecionadas, em exposição no MAM do Rio, para a VI Bienal de Paris" ${ }^{\prime 2}$. No exterior, foi o crítico Pierre Restany o propagador dessa bandeira: organizou em 16 de junho de 1969, no Museu de Arte Moderna de Paris, uma reunião na qual artistas e intelectuais elaboraram uma petição de boicote, com cerca de 300 assinaturas, enviada a Ciccillo Matarazzo ${ }^{83}$.

Pierre Restany, aderindo ao boicote, se retirou da organização da sala especial internacional "Arte e tecnologia", tarefa iniciada por ele ainda em 1968. Os trabalhos estavam bastante adiantados quando isso aconteceu. Juntamente com o crítico francês, também se retiraram artistas e instituições tecnológicas que fariam parte dela ${ }^{84}$. Por esse motivo, a sala não foi concretizada.

Países como Estados Unidos, França, México, Suécia e Argentina, bem como vários artistas, isoladamente, aderiram ao boicote logo de início. Ao longo da organização da mostra, houve ainda muitas desistências de última hora, entre elas a União Soviética. Muitos desses países, inclusive, se retiraram das bienais por várias edições ${ }^{85}$. Algumas delegações de artistas que resolveram se retirar da Bienal já tinham suas obras no Pavilhão Armando Arruda Pereira, em fase de montagem. Esse foi um dos problemas que a organização da mostra teve que contornar.

\footnotetext{
${ }^{80}$ AMARANTE, Leonor. As Bienais de São Paulo: 1951 a 1987. São Paulo: Projeto, 1989, p. 182.

${ }^{81}$ ALAMBERT, Francisco \& Polyana CANHÊTE. Bienais de São Paulo: da era do museu à era dos curadores. São Paulo: Boitempo, 2004.

82 Cf. Cronologia. In PEDROSA, Mário. Política das Artes, (org.) Otília Beatriz Fiori Arantes. São Paulo: EDUSP, 1995, p. 360.

${ }^{83}$ ALAMBERT, Francisco \& Polyana CANHÊTE. Bienais de São Paulo: da era do museu à era dos curadores. São Paulo: Boitempo, 2004, p. 124-25.

${ }^{84}$ AMARANTE, Leonor. As Bienais de São Paulo: 1951 a 1987. São Paulo: Projeto, 1989.

${ }^{85}$ AMARANTE, Leonor. As Bienais de São Paulo: 1951 a 1987. São Paulo: Projeto, 1989.
} 
Artistas e intelectuais se dividiam, basicamente, em duas posições: aderir ou não ao boicote, com as implicações decorrentes disso, a saber, dar aval ou protestar contra o sistema político de forças que amparava a Bienal ${ }^{86}$. Nesse contexto, apesar de assumidamente comunista, Mario Schenberg optou por levar adiante sua função de jurado na seleção das obras daquela edição. $\mathrm{O}$ crítico não apenas se posicionou contra o boicote, como organizou a sala Novos Valores, assinando o texto de apresentação no catálogo da mostra ${ }^{87}$.

Mas não se pode dizer que, ao participar da Bienal e levar adiante sua colaboração no Júri de Seleção e organização geral, o crítico estivesse dando seu aval ao estado de coisas. Leonor Amarante destaca que seu posicionamento era diferente: dar continuidade a sua função no Júri de Seleção significava ocupar um espaço que, apesar de todos os problemas e críticas com que tinha de lidar, ainda era o foro mais privilegiado para as Artes Plásticas no país.

Boicotar a Bienal, nesse sentido, significaria deixar de defender os interesses dos artistas, bem como seu espaço na mostra internacional. Por isso, o crítico não via sua participação como adesão aos desmandos do regime totalitário, mas como uma forma de protesto, na medida em que marcava sua posição ${ }^{88}$.

Com relação à formação do Júri de Seleção da X Bienal, é preciso acrescentar que não foi isenta de polêmicas. A Associação Brasileira de Críticos de Arte e a Associação Internacional de Artistas Plásticos (sessão nacional) reivindicavam representação nesse Júri, bem como na Assessoria Técnica e nas comissões que realizariam a organização da mostra. Em janeiro de 1969, as duas associações recusam o convite da Fundação Bienal para esta última, pois entendiam que não fazia sentido "terem representantes no certame a se realizar em setembro próximo sujeitos a acatarem as decisões da Fundação Bienal, que terá sempre maioria de membros e, portanto, de votos" ${ }^{\prime 89}$.

Além disso, as decisões da Assessoria Técnica teriam de passar pela aprovação da Diretoria da Bienal, que não era formada por pessoas conhecedoras de arte. Essa era, aliás, uma crítica à organização das bienais que vinha desde a extinção da função de Diretor Geral,

${ }^{86}$ FUNDAÇÃO BIENAL DE SÃO PAULO. 50 anos Bienal de São Paulo: 1951-2001. (catálogo de exposição) São Paulo: Fundação, 2001.

${ }^{87}$ AMARANTE, Leonor. As Bienais de São Paulo: 1951 a 1987. São Paulo: Projeto, 1989, p. 184. Cf. texto de apresentação da sala especial em SHCNBERG, Mario. Novos Valores, in FUNDAÇÃO BIENAL. X Bienal. (catálogo de exposição) São Paulo: Museu de Arte Moderna de São Paulo, 1969, p. 445.

${ }^{88}$ Novamente, o livro de Leonor Amarnte (As Bienais de São Paulo: 1951 a 1987. São Paulo: Projeto, 1989) foi a única fonte que permitiu situar a posição de Mario Schenberg nessa ocasião. É possível que, no futuro, a continuidade das pesquisas sobre sua atuação nas bienais traga à luz outras fontes, inclusive primárias, a esse respeito. Agradecimentos são devidos a Alecsandra Matias de Oliveira, Palyana Canhête e Francisco Alambert, pela contribuição em relação a esse ponto.

${ }^{89}$ AIAP e ABCA recusam convite da Bienal. Folha de São Paulo, 01 de fevereiro de 1969. 
a partir da VII Bienal. Diante desses aspectos, as suas associações consideravam muito difícil o diálogo com a Bienal. Finalmente, dado o convite tardio e o fato de que todas as decisões já haviam sido tomadas, não era possível "assumir a responsabilidade de uma programação já estabelecida", apoiando-a "como entidades especializadas"90.

Já no que tange ao Júri de Seleção, o convite foi aceito, mas não sem restrições. Em 2 de maio do mesmo ano, a Fundação Bienal convida a AIAP a enviar uma lista com cinco nomes eleitos por seus quadros sociais, a fim de escolher dentre as sugestões um representante para integrá-lo ${ }^{91}$. A resposta, contudo, não foi a lista solicitada, mas um único nome, conforme se lê:

[...] nossa entidade, atendendo, solícita, ao pedido da Fundação Bienal, promoveu eleições livres em São Paulo e no Rio para a indicação de um membro do Júri de Seleção, convocando todos os artistas interessados, mesmo aquêles que não pertencem aos seus quadros sociais. Infelizmente não estamos aparelhados para promover eleições em outras cidades brasileiras. O resultado, portanto, não tem valor nacional. [...] Da nossa consulta, resultou como o mais votado o crítico de arte Mário Schenberg 92 .

Constata-se que, também na Bienal de 1969, Mario Schenberg integrou o Júri com o apoio dos artistas, mesmo que não tenha havido uma eleição organizada pela Fundação Bienal. Maurício Nogueira Lima, então presidente da AIAP lembra, ainda, que a associação defendeu, quando da elaboração do regulamento da X Bienal, a posição de que a eleição deveria ser realizada diretamente por essa instituição. Isso foi feito, segundo o artista, por meio de um representante na Assessoria, o que sugere que, após a recusa inicial, a AIAP aceitou a representação nessa comissão, possivelmente após negociação a respeito dos pontos levantados.

Desse modo, integraram o Júri de Seleção os seguintes nomes: Mark Bercowitz (indicado pela ABCA), Mario Schenberg (pela AICA), Edyla Mangabeira Unger, Oswaldo de Andrade Filho e Walmir Ayala (pela Fundação Bienal). Segundo o regulamento da X Bienal, caberia ao Júri convidar 25 artistas e escolher, entre os inscritos, outros 25 . No que diz

\footnotetext{
${ }^{90}$ Resposta oficial enviada a Francisco Matarazzo Sobrinho por Quirino Campofiorito ( $1^{\mathrm{o}}$ Vice-Presidente da AICA) e Mirian Quiaverini (Presidente da AIAP), correspondência datada de 31 de Janeiro de 1969. Arquivo Histórico Wanda Svevo, Fundação Bienal.

${ }^{91}$ Carta de Francisco Matarazzo Sobrinho a Maurício Nogueira Lima (Presidente da AIAP), datada de 2 de maio de 1969. Arquivo Histórico Wanda Svevo, Fundação Bienal.

92 Carta de Maurício Nogueira Lima (Presidente da AIAP) a Francisco Matarazzo Sobrinho, datada de 16 de maio de 1969, p. 1 (foi mantida a grafia original). Arquivo Histórico Wanda Svevo, Fundação Bienal.
} 
respeito às salas especiais, os membros entendiam que os artistas não seriam escolhidos entre os convidados regulamentares ${ }^{93}$.

A partir da análise das atas das reuniões do Júri de Seleção disponíveis no Arquivo Histórico Wanda Svevo, é possível ver que Mario Schenberg foi muito participativo nas discussões, e manteve-se sempre a favor dos artistas, na medida em que discordava de qualquer sugestão de diminuição do número da representação brasileira.

Como exemplo, pode-se destacar que, diante da recusa de muitos dos artistas convidados (entre eles estavam Lygia Clark, Hélio Oiticica, Rubens Gerchmam, Burle Marx, Carlos Vergara), mesmo após terem sido convidados os cinco suplentes, o crítico sugeriu que as vagas fossem redirecionadas para os artistas inscritos, com o que concordaram os demais membros do Júri ${ }^{94}$.

Mario Schenberg defendeu, ainda, a organização das salas especiais previstas, a saber, "Etapas", "Novos Valores", “Arte Mágica, Fantástica e Surrealista”, das quais apenas as duas últimas constam no catálogo da mostra. Foi cogitada também a organização de uma sala especial dedicada aos movimentos Concreto e Neo-concreto, que não chegou a ser realizada. No entender do crítico, era importante ter as salas especiais, a fim de garantir o alto nível da representação brasileira uma vez que muitos convidados haviam se recusado a participar da $\mathrm{X}$ Bienal.

No que diz respeito à sala "Arte Mágica, Fantástica e Surrealista”, Mario Schenberg sugere que o número de artistas seja elevado e observa que seria interessante, antes de escolher os artistas, elaborar critérios para tanto: “[h]á artistas de valor indubitável, mas que não estão apresentando novidades. Atingiram seu maior desenvolvimento no passado e ficaram cristalizados. Devem, portanto, considerar dois grupos para a sala: o dos artistas mais antigos, e o dos novos"

Em entrevista à revista Trans/Form/Ação, concedida na década de 1980, o Professor Schenberg comenta que o Júri chegou a descer ao porão da Fundação Bienal para ver se havia ali alguma obra para essa sala, já que não havia muitos trabalhos em vista. Na ocasião, Mario

\footnotetext{
${ }^{93}$ Nota divulgada à imprensa pela Fundação Bienal, em 28 de maio de 1969, intitulada: “Júri da X Bienal convida vinte e cinco artistas". Arquivo Histórico Wanda Svevo, Fundação Bienal. Cf. também FUNDAÇÃO BIENAL. X Bienal. (catálogo de exposição) São Paulo: Fundação Bienal, 1969. Regulamento: Capítulo II, V, $a$, p. 449.

${ }_{94}$ Ata do Júri de Seleção, dia 26/06/1969, p. 1. Arquivo Histórico Wanda Svevo, Fundação Bienal.

${ }^{95}$ Ata do Júri de Seleção, dia 07/07/1969, p. 1. Arquivo Histórico Wanda Svevo, Fundação Bienal.
} 
Schenberg recorda que foram apontadas algumas obras (abandonadas pelo artista na Bienal), que o impressionaram muito quando foram enviadas para edições anteriores da mostra ${ }^{96}$.

No decorrer das reuniões do Júri de Seleção foram feitas sugestões no sentido de selecionar, entre os artistas inscritos espontaneamente, os integrantes das salas especiais. Edyla Mangabeira Unger e Marc Bercowitz eram da opinião de que, se não fossem escolhidos para as salas especiais os inscritos, não haveria artistas suficientes. Para Walmir Ayala, uma representação com 30 artistas poderia ser tão boa quanto uma com $50^{97}$.

José Humberto Affonseca (que acompanhava Francisco Matarazzo Sobrinho numa intervenção pontual a fim de esclarecer o Júri sobre a possibilidade de mudar o regulamento) sugeriu que fosse feita uma seleção entre os inscritos sem publicidade. Nesse caso, seria apenas publicada uma lista com o nome dos artistas ao fim da seleção ${ }^{98}$.

Mario Schenberg se opôs terminantemente a qualquer mudança do regulamento no meio dos trabalhos, bem como à escolha de artistas inscritos para as salas especiais, chegando mesmo a declarar que, caso o regulamento não fosse cumprido, se retiraria do Júri ${ }^{99}$. Em seu entender, isso significaria uma mudança de posição que prejudicaria os artistas, na medida em que permitiria diminuir ainda mais uma representação que, nessa edição, já seria bem reduzida em relação às anteriores.

Na X Bienal de São Paulo, Mario Schenberg organizou uma retrospectiva de Ismael Nery com 50 desenhos. Além disso, foi responsável pela sala especial "Novos Valores", da qual participaram 28 artistas jovens de diversas técnicas e tendências como, por exemplo, Gilberto Salvador, Antônio Peticov, Cláudio Tozzi, Carmela Gross, José Roberto Aguilar, Yutaka Toyota, Marcelo Nitsche, João Câmara e Ione Saldanha ${ }^{100}$. Para realizá-la, o crítico enfrentou resistência dos outros membros do Júri de Seleção, que julgavam-na redundante, já que o propósito da Bienal era apresentar o que havia de mais recente ${ }^{101}$.

Na apresentação que escreveu para sala "Novos Valores", Mario Schenberg chamou a atenção para o fato de haver, já entre os artistas selecionados e os convidados, muitos jovens que se encaixariam na proposta daquela sala. Vários deles, apesar da pouca idade, já teriam se

96 SHCNBERG, Mario. Entrevista com Mário Schenberg. (Publicado originalmente na Revista Trans/Form/Ação, v. 3, p. 6-62, 1980). In Trans/Form/Ação. Marília, v.34, 2011. Edição Especial, p. 154. O crítico diz não se recordar do nome do artista, motivo pelo qual não foi possível saber se os trabalhos mencionados foram expostos ou não.

${ }^{97}$ Ata do Júri de Seleção, dia 07/07/1969, p. 1. Arquivo Histórico Wanda Svevo, Fundação Bienal.

${ }^{98}$ Ata do Júri de Seleção, dia 07/07/1969, p. 2. Arquivo Histórico Wanda Svevo, Fundação Bienal.

${ }^{99}$ Ata do Júri de Seleção, dia 07/07/1969, p. 2. Arquivo Histórico Wanda Svevo, Fundação Bienal.

${ }^{100}$ AMARANTE, Leonor. As Bienais de São Paulo: 1951 a 1987. São Paulo: Projeto, 1989.

101 Ata do Júri de Seleção, dia 07/07/1969, p. 2. Arquivo Histórico Wanda Svevo, Fundação Bienal. Não foram localizadas as atas das reuniões posteriores a essa data. Por isso, não foi possível reconstituir o desfecho dos debates sobre a sala Novos Valores. 
tornado personalidades significativas no meio artístico brasileiro ${ }^{102}$. Havia, contudo, muitos outros artistas que pareceram dignos de serem apresentados, mesmo que suas propostas não tivessem ainda uma realização tão definida quanto seus colegas mencionados, o que motivou a organização dessa sala especial ${ }^{103}$.

Para Mario Schenberg, os artistas jovens eram sensíveis aos novos valores que estavam emergindo não apenas de causas de natureza geral (questões demográficas, sociais, políticas e culturais), mas também transformações específicas das artes plásticas, a saber, o declínio do abstracionismo informal, a emergência da arte objetista, da Pop Art e de tendências neo-dadaistas, assim como a utilização cada vez maior de novos recursos tecnológicos, como a eletrônica, e de novos materiais ${ }^{104}$.

Esses novos caminhos teriam diminuído a importância da longa formação artesanal requerida pelos gêneros tradicionais das artes plásticas, ao mesmo tempo em que abriram um vasto repertório de possibilidades para as novas formas de expressão artística. Se muitos artistas experientes estavam indo em direção a essas novas possibilidades, eram os jovens que se sentiam muito mais atraídos por elas, uma vez que frequentemente não conseguiam mais se realizar pelas técnicas tradicionais da pintura ${ }^{105}$.

Ao fim do texto, Mario Schenberg pontua que seria prematuro tecer previsões sobre os rumos dessas novas tendências, embora algumas delas já fossem sentidas internacionalmente, como o declínio do Pop e do Op, o aparecimento de novos tipos de construtivismo e o surto mágico-fantástico. Mas era possível notar, por um lado, o domínio mais seguro das novas técnicas e dos novos materiais em relação à IX Bienal e, por outro, a diminuição do ritmo explosivo anterior, indicando, talvez, a busca de novos caminhos da década de $1970^{106}$.

Em relação à X Bienal de São Paulo, o crítico manifestou o mesmo critério da edição anterior em relação à escolha dos artistas para representar a arte brasileira no evento, isto é, privilegiar propostas inovadoras. Os planos para a montagem da exposição, contudo, não foram totalmente viabilizados devido a problemas (já apontados) com a organização do evento. A falta de tempo para que os artistas se inscrevessem e o movimento internacional de

\footnotetext{
102 SCHENBERG, Mario. Novos Valores, in FUNDAÇÃO BIENAL. X Bienal. (catálogo de exposição) São Paulo: Fundação Bienal, 1969, p. 44 e 45.

${ }^{103}$ SCHENBERG, Mario. Novos Valores, in FUNDAÇÃO BIENAL. X Bienal. (catálogo de exposição) São Paulo: Fundação Bienal, 1969.

${ }^{104}$ SCHENBERG, Mario. Novos Valores, in FUNDAÇÃO BIENAL. X Bienal. (catálogo de exposição) São Paulo: Fundação Bienal, 1969.

${ }^{105}$ SCHENBERG, Mario. Novos Valores, in FUNDAÇÃO BIENAL. X Bienal. (catálogo de exposição) São Paulo: Fundação Bienal, 1969.

${ }^{106}$ SCHENBERG, Mario. Novos Valores, in FUNDAÇÃO BIENAL. X Bienal. (catálogo de exposição) São Paulo: Fundação Bienal, 1969.
} 
contestação à Bienal fizeram com que o número de artistas convidados ficasse abaixo do número estabelecido inicialmente ${ }^{107}$.

Mesmo assim, Schenberg fez algumas considerações interessantes sobre a predominância de artistas jovens que marcou a representação do país (muitos dos quais participaram da Bienal com o apoio do crítico); a diminuição de quadros e esculturas, relacionada com o aumento das pesquisas concernentes à arte objetista, e o desenvolvimento de novas formas de expressão (arte conceitual, sinestésica, além de recursos tecnológicos elétricos, eletrônicos e de novos materiais) ${ }^{108}$.

Tendo isso em vista, é possível destacar a instalação da artista Mira Schendel, com quem o crítico manteve contato prolongado, tendo escrito diversos textos sobre seu trabalho. Ondas Paradas de Probabilidade (que recebeu menção honrosa) consistia num ambiente com fios de náilon transparentes presos ao teto, entre os quais os visitantes poderiam se movimentar no espaço expositivo.

Como membro do Júri de Seleção da X Bienal, Mario Schenberg participou, ainda, de uma Mesa Redonda, para a qual foram convidados críticos de arte do Brasil e do exterior. O evento foi realizado no auditório da Fundação Bienal, nos dias 27 e 28 de setembro de 1969. A coordenação da mesa redonda ficou a cargo do crítico Sergio Ferro e seu objetivo era discutir aspectos da organização e da premiação das bienais, com vistas a sua reformulação ${ }^{109}$. Walmir Ayala afirma ${ }^{110}$, no artigo A Bienal em Questão, que o modelo adotado pela Bienal não correspondia mais

à evolução do espírito criador contemporâneo e, como tantas outras organizações sócio-festivas, de promoção artística, estaria corrompida do maneirismo burguês, entre o balanço do comércio, a nutrição do veditismo, o delírio da sofisticação e a ronda da politicagem.

A inadequação da Bienal de São Paulo às mudanças que aconteceram na arte durante os anos de 1960 também davam o tom de outras discussões: a escolha do Júri de Premiação, seus critérios de decisão e, no limite, a própria existência das premiações, consideradas opulentas, foram alguns dos itens do temário da Mesa Redonda. Foram postos em discussão,

\footnotetext{
107 SCHEnBerg, Mario. Pensando a Arte, São Paulo: Nova Stella, 1988.

${ }^{108}$ SCHENBERG, Mario. Pensando a Arte, São Paulo: Nova Stella, 1988.

${ }^{109}$ Críticos de Arte vão debater reformulação das bienais. Nota enviada à imprensa, documento não datado. Arquivo Histórico Wanda Svevo, Fundação Bienal.

${ }^{110}$ Walmir Ayala, A Bienal em Questão. Jornal do Brasil (Rio de Janeiro), 27/09/1969.
} 
ainda, o modelo das representações divididas por países (e não por tendências), bem como a inexistência de uma instância diretiva formada por conhecedores de arte na organização ${ }^{111}$.

${ }^{111}$ Sobre as críticas a respeito da gestão e organização das Bienais, cf. Mário Barata. Aspectos Organizativos da Bienal. Jornal do Comércio (Rio de Janeiro), 12/10/1969, Walmir Ayala, Júris, pra quê?, Jornal do Comércio (Rio de Janeiro), 14/10/1969 e Arnaldo Pedroso D’Horta, Ainda a Bienal, Jornal da Tarde (São Paulo), 22/10/1969. 


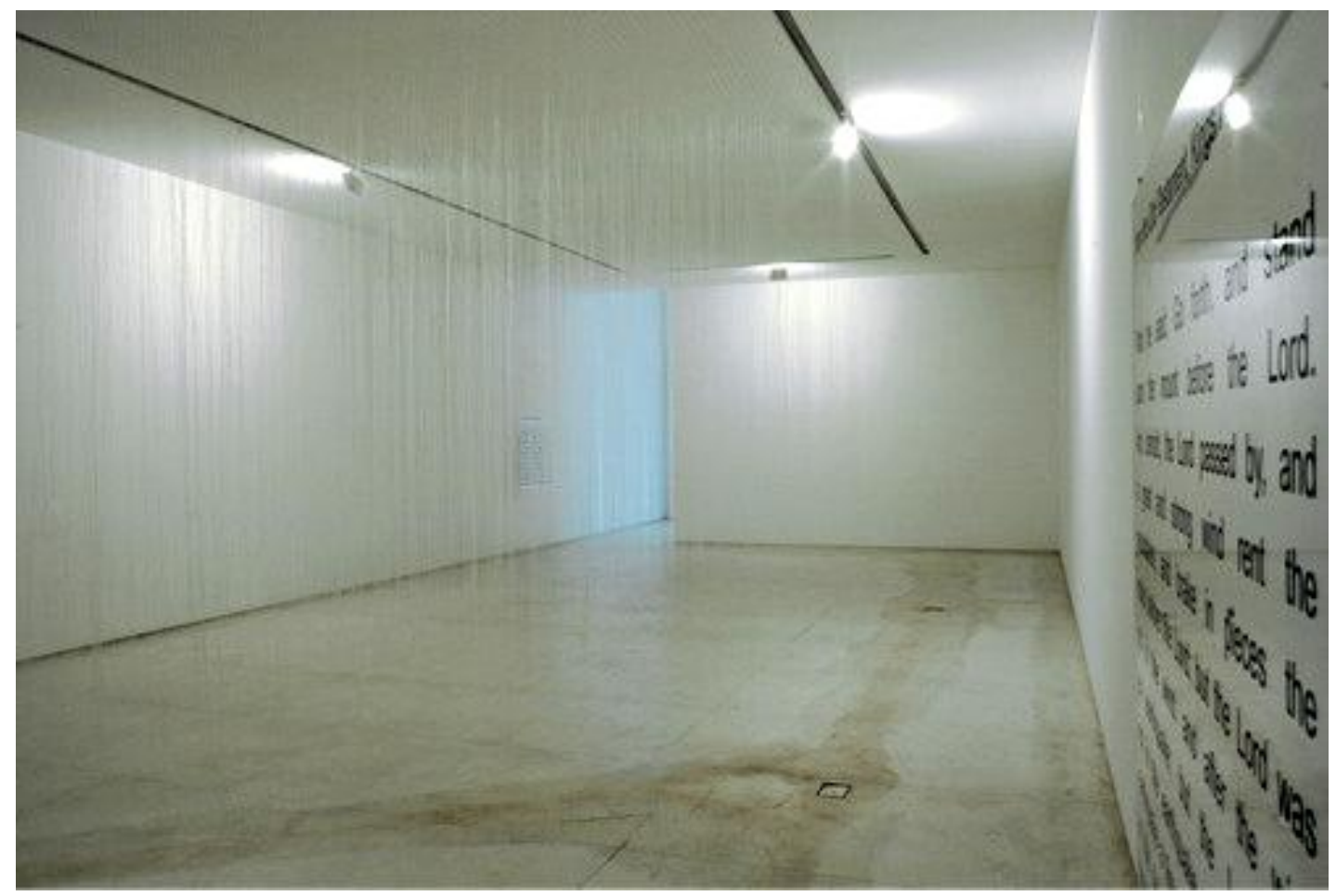

Figura 9 - Mira Schendel, Ondas Paradas de Probabilidade, 1969 (recriada em 2009), instalação, dimensões variáveis. Fios de náilon e texto em placa de acrítico afixado na parede. Coleção Ada Schendel. 
Poucos dias antes da realização da Mesa Redonda, muitos críticos de arte brasileiros se recusaram a participar dos seminários, manifestando descontentamento pelo fato de não terem recebido convite oficial com antecedência. A ABCA entendeu o fato como descaso quanto à participação dos críticos de arte do país. Afirmava que a sugestão da realização do evento teria partido da ABCA e da AIAP, mas ressurgia "inteiramente desvirtuada"112, o que demonstrava a direção amadorística da bienal. Criticava, também, a inclusão de alguns críticos à revelia na lista de nomes para o evento, paralelamente à exclusão de vários outros $^{113}$.

Estruturalmente, o evento se dividiu em dois momentos: no primeiro dia, cuja programação teve início às 17 horas, foram apresentadas quatro comunicações que deram início ao exame do temário: Riszard Stanislawsky, da Polônia, falou sobre a "Finalidade das exposições Internacionais"; Hernandez Campos, do México, sobre "Organização das Exposições Internacionais"; Yona Fischer, de Israel, sobre "Os críticos de premiação" e, finalmente, Mario Schenberg, falou sobre o "Apoio à pesquisa em arte". Cada um deles teve a palavra durante vinte minutos, após o que se seguiu um pequeno debate. ${ }^{114}$.

No dia seguinte, foi realizada pela manhã uma rodada de debate da crítica especializada (às 10 horas) e, à tarde, tiveram lugar reuniões entre os críticos (às 16 horas) e no fim da tarde, uma plenária para aprovação de redação das recomendações da Mesa Redonda (às 17 horas). A coordenação dos debates foi feita pelo crítico Marc Bercowitz, que representava o Brasil no Júri Internacional de Seleção ${ }^{115}$.

Os debates foram registrados em ata, que não foi localizada no Arquivo Histórico Wanda Svevo. Sem esse documento, não foi possível reconstituir a fala de Mario Schenberg, nem suas intervenções nos debates ocorridos. Contudo, em sua manifestação na Mesa

\footnotetext{
${ }^{112}$ Cf. telegrama assinado pelos críticos: Pedro Manuel Gismondi, Antônio Bento, Aracy Amaral, Maria Eugênia Franco, José Roberto Teixeira Leite, Theon Spanudis, Waldemar Cordeiro e Walter Zanini, datado de 25 de setembro de 1969 (Arquivo Histórico Wanda Svevo, Fundação Bienal), que foi publicado no Diário de Notícias (Rio de Janeiro) em 3 de outubro de 1969, em nota de Frederico Morais, intitulada Mesa Redonda e Protesto. Vale lembrar que já em 1965 foi feita a proposta de realização de um simpósio de críticos de arte a fim de repensar a estrutura da Bienal. Cf. JORDÂO, Vera Pacheco. Os críticos e a Bienal. O Globo (Estado da Guanabara), 17/08/1965.

${ }^{113}$ No mesmo dia, Edyla Mangabeira Unger (membro do Júri de Seleção e da comissão técnica) fez saber à Fundação Bienal que, devido ao fato de seus colegas da ABCA não terem sido convidados com a devida antecedência, não participaria da Mesa Redonda. Cf. telegrama datado de 25 de setembro de 1969. Arquivo Histórico Wanda Svevo, Fundação Bienal.

${ }^{114}$ Cf. Regimento Interno do evento. Documento não datado. Arquivo Histórico Wanda Svevo, Fundação Bienal. O evento era aberto ao público, mas este não tinha voz. Contudo, era possível que ele se manifestasse por escrito, sendo as sugestões depositadas em urnas destinadas a esse fim.

115 Programação da Mesa Redonda de Críticos de Arte - X Bienal. Documento não datado. Arquivo Histórico Wanda Svevo, Fundação Bienal. O evento era aberto ao público, mas este não tinha voz. Contudo, era possível se manifestar por escrito, sendo as sugestões depositadas em urnas destinadas a esse fim.
} 
Redonda de 1971, também organizada pela Fundação Bienal, o crítico indica que já se tinha "pensado nos mesmos problemas na mesa redonda anterior. Infelizmente, como acontece aqui na Bienal, todas as sugestões são engavetadas" ${ }^{\prime 16}$. Tem-se, com isso, uma pista a respeito de seu posicionamento. Todavia, essa contribuição será analisada mais a frente.

Foi elaborado, ao final da Mesa Redonda, um documento contendo as observações dos críticos de arte. As recomendações não se referiam apenas à Bienal de São Paulo como também às demais grandes exposições do circuito internacional. Entre as principais delas, constavam: a manutenção das representações por país (dado que não havia outra maneira de garantir igualdade de oportunidade a países de diferentes situações econômicas e culturais de exporem sua produção artística); a abertura a realização de manifestações como happenings e arte que envolva participação humana, e a contribuição para a ampliação das possibilidades artísticas e à plena liberdade de sua manifestação ${ }^{117}$.

Entre as outras recomendações, chamou atenção a seguinte: a promoção de condições para que artistas desenvolvam pesquisas por meio da criação, de modo semelhante ao que já ocorria já na pesquisa acadêmica (concessão de bolsas e fundos de fomento, por parte de instituições de diversos países); a formação de uma comissão coordenadora para levar adiante a consulta aos meios especializados com relação às recomendações (essa comissão trabalharia em coordenação com a direção da Fundação Bienal) ${ }^{118}$.

Ao fim dessa longa lista, era ressaltado, ainda, que a permanência das representações nacionais e a reformulação da premiação foram os pontos mais controversos. A primeira, pelo motivo já explicitado; a segunda, por não ter havido concordância entre as diversas possibilidades apresentadas $^{119}$.

A presença de uma recomendação sobre o fomento à pesquisa artística entre as resoluções finais do evento parece indicar que a fala de Mario Schenberg no primeiro dia dos trabalhos teve repercussão. O tema de sua comunicação (Apoio à pesquisa em arte), somado à sua vivência no campo da pesquisa científica e à defesa da necessidade de incentivar os artistas jovens, própria do crítico, foram os elementos que levaram a essa suposição.

\footnotetext{
${ }^{116}$ Mario Schenberg. Transcrição de sua intervenção na Mesa Redonda de 1971. Documento não datado, p. 7. Arquivo Histórico Wanda Svevo, Fundação Bienal (foi mantida a grafia original do texto).

${ }^{117}$ Documento intitulado Recomendações da Mesa Redonda de críticos de arte internacionais, não datado, com duas páginas. Arquivo Histórico Wanda Svevo, Fundação Bienal.

${ }^{118}$ Documento intitulado Recomendações da Mesa Redonda de críticos de arte internacionais, não datado, com duas páginas. Arquivo Histórico Wanda Svevo, Fundação Bienal.

${ }^{119}$ Documento intitulado Recomendações da Mesa Redonda de críticos de arte internacionais, não datado, com duas páginas. Arquivo Histórico Wanda Svevo, Fundação Bienal.
} 
Infelizmente, como já foi dito, não foram encontradas as transcrições dos debates realizados para tecer considerações mais precisas.

\section{Mesa-redonda: XI Bienal (1971)}

A XI Bienal esteve aberta ao público entre 4 de setembro e 15 de novembro de 1971, trazendo 351 artistas de 57 países, num total de 2.459 obras. A comissão técnica que organizou a mostra de artes visuais foi composta por Antônio Bento, Geraldo Ferraz e Sérgio Ferro $^{120}$.

Para Aracy Amaral, essa edição marcou o início dos "anos baixos" das Bienais, na medida em que, cada vez mais, Ciccilo Matarazzo delegava a amigos empresários, e não a profissionais especializados, a concepção desses eventos ${ }^{121}$. Embora algumas mudanças tivessem ocorrido como, por exemplo, a realização de Pré-Bienais, que tentou responder ao criticado modelo de escolha anterior, muitos outros pontos de seu funcionamento ainda eram postos em xeque por parte de artistas e críticos de arte.

Alguns deles, como a ausência de uma direção geral competente que conferisse unicidade à mostra internacional, eram apontados desde que as bienais foram desvinculadas do MAM-SP. Era forte, ainda, a constatação de que as bienais não estavam sendo capazes de acompanhar os desdobramentos mais recentes da arte contemporânea que, a partir da segunda metade da década anterior, sofrera transformações profundas, como a desconstrução dos suportes tradicionais e a arte conceitual, por exemplo.

Além disso, ecos do boicote internacional se faziam sentir mais profundamente nessa edição. Os Estados Unidos se retiraram da mostra e França, Itália e Grâ-Bretanha tiveram poucos artistas. No ano anterior, Mário Pedrosa tinha se exilado no Chile devido à ameaça de prisão, contra o que protestaram artistas como Pablo Picasso, Alexander Calder, Max Bill e Henry Moore $^{122}$.

A linha geral da XI Bienal foi a comemoração dos vinte anos da mostra, realizada em clima retrospectivo, homenageando a si própria. Nesse espírito, foram organizadas diversas

\footnotetext{
${ }^{120}$ FUNDAÇÃO BIENAL. Bienal a Bienal. Disponível em: http:/www.bienalorg.br/FBSP/pt/AHWS/BienalaBienal/Paginas/6BienalSaoPaulo.aspx?selected=6 Acesso em 15/01/2013. ${ }^{121}$ AMARAL, Aracy. Bienais ou Da impossibilidade de reter o tempo. REVISTA USP, São Paulo, n. 52, p. 16-25, dezembro/fevereiro 2001-2002.

${ }^{122}$ ALAMBERT, Francisco \& Polyana CANHÊTE. Bienais de São Paulo: da era do museu à era dos curadores. São Paulo: Boitempo, 2004.
} 
salas especiais dedicadas a artistas premiados desde 1951, contrariando o propósito maior do certame: dar visibilidade às tendências mais recentes da arte nacional e internacional.

Nessa ocasião, Mario Schenberg não integrou o Júri de Seleção, mas fez parte de uma Mesa Redonda semelhante à realizada na Bienal anterior. De acordo com o depoimento já citado, Schenberg ${ }^{123}$ aponta o motivo pelo qual não pôde continuar envolvido na organização das edições posteriores à de 1969:

Eu, que já tinha organizado a primeira exposição de Volpi em 1944, organizei em 61 a sua primeira retrospectiva. Depois disso, começaram a votar para que eu fizesse parte dos júris de seleção das Bienais. O primeiro júri que integrei foi em 1965 , depois 67 e 69. E, a partir daí, a Bienal me aplica o Ato 75.

Nesse sentido, cabe perguntar o que foi o Ato 75 e como ele impediu o crítico de continuar participando dos Júris. Teria ele participado do Júri se a Bienal não tivesse lhe aplicado o Ato? O depoimento dá a entender que Mario Schenberg teria sido eleito pelos artistas, mas sua atuação foi impedida pela Bienal. As considerações a seguir tentarão dar conta dessas dúvidas, na medida do possível.

Primeiramente, é preciso observar que o crítico se refere ao Ato Complementar Número 75, editado em 21 de Outubro de 1969, o qual decretava que:

Todos aqueles que, como professor, funcionário ou empregado de estabelecimento de ensino público, incorreram ou venham a incorrer em faltas que resultaram ou venham a resultar em sansões com fundamento em Atos Institucionais, ficam proibidos de exercer, a qualquer título, cargo, função, emprego ou atividades, em estabelecimentos de ensino e em fundações criadas ou subvencionadas pelos Poderes Públicos, tanto da União, como dos Estados, Distrito Federal, Territórios e Municípios, bem como em instituições de ensino ou pesquisa e organizações de interesse da segurança nacional $^{124}$.

Funcionando como uma espécie de arremate do AI 5, o Ato Complementar 75 fechava as portas do mercado de trabalho aos professores universitários que foram objeto de

\footnotetext{
${ }^{123}$ SCHENBERG, Mario. Depoimento. In AJZNBERG, Elza. Schenberg - Arte e Ciência. São Paulo: ECA/USP, 1995, p. 142.

124 ATO Complementar no $\mathbf{7 5}$, de 21 de outubro de 1969, Diário Ofícial da União, p. 8930. Disponível em: http://www.planalto.gov.br/ccivil 03/ACP/acp-75-69.htm Acesso em: 20/02/2013. Esse Ato Complementar foi assinado, por Luíz Antônio da Gama e Silva, que foi reitor da Universidade de São Paulo e assinou também o AI-5, e por Antônio Delfim Neto, docente da Faculdade de Economia e Administração da USP. Agradecimentos são devidos ao Prof. Fr. Francisco Alambert pelo auxílio e pelas conversas a respeito do aspecto social e político desse período.
} 
perseguição do regime militar. Isso porque não existiam instituições de ensino e de pesquisa que, de alguma forma, não recebessem algum tipo de verba ou subvenção pública ${ }^{125}$.

Mario Schenberg, que desde sua aposentadoria compulsória dava seminários semanais no Centro Brasileiro de Pesquisas Físicas, sediado no Rio de Janeiro, foi dispensado da instituição, que se enquadrava nos termos desse Ato Complementar. Levando-se em consideração que a Fundação Bienal era financiada por verbas estaduais e municipais, pode-se compreender o motivo pelo qual suas portas também se fecharam ao crítico. Em entrevista ao jornal Folhetim em 1977, Mario Schenberg ${ }^{126}$ definiria suas limitações de maneira bastante clara:

\footnotetext{
A aposentadoria dos professores é regulamentada por um ato complementar drástico que não nos permite trabalhar mais em quase nada: não podemos mais trabalhar em nenhuma universidade do País, ou em organizações particulares que recebem auxílio do governo. Assim, não temos mais acesso a laboratórios e bibliotecas, não podemos mais assistir seminários, participar de debates, etc, promovidos dentro dessas instituições.
}

A partir disso, já se sabe que, mesmo que o crítico tivesse sido escolhido pelos artistas, estava impedido de atuar na Fundação Bienal. Mas resta saber se ele de fato foi o vencedor da eleição, que voltou a ser promovida pela própria instituição.

Para entender como funcionou o Júri da IX Bienal, é necessário ter em vista que, em 1970, teve lugar a I Pré-Bienal de São Paulo, conforme já foi apontado, no período que foi de 12 de setembro a 25 de outubro de 1970. Essa nova estrutura de seleção mudou o modo de escolha do Júri de Seleção da Bienal Internacional.

A mostra teve o intento de reunir manifestações artísticas de todas as partes do país, tirando a participação brasileira nas bienais internacionais do eixo Rio-São Paulo. Para isso, foram realizadas seleções em diferentes estados. A região Nordeste, por exemplo, chegou a organizar uma "Pré-pré-bienal", realizando uma exposição que reunia os artistas cujos trabalhos seriam submetidos ao Júri de Seleção itinerante.

Com as diversas pré-seleções, foi necessário que os membros do Júri se deslocassem pelo Brasil, o que tornou os trabalhos mais dispendiosos. O corpo de jurados teve variações da localidade para localidade, mantendo sempre um representante da Fundação Bienal. Foram realizadas seleções locais em Manaus, Belém, Recife, Belo Horizonte, Goiânia, Brasília,

${ }^{125}$ CLEMENTE, José Eduardo Ferraz. Ciência e política durante a ditadura militar: o caso da comunidade brasileira de físicos (1964-1979). Salvador: Universidade Federal da Bahia, Instituto de Física, 2005. (dissertação de Mestrado), p. 128-29.

${ }^{126}$ Mario Schenberg. Jornal Folhetim, 24 de julho de 1977. 
Campo Grande, Guanabara (atual Rio de Janeiro), São Paulo, Curitiba, Florianópolis e Porto Alegre $^{127}$.

Mario Schenberg, que não concordou com a criação das Pré-Bienais, não fez parte desse Júri itinerante. Apesar de ser natural supor que, por isso, o crítico não tenha participado das diversas seleções, não há certeza sobre esse ponto, pois não foi encontrada documentação que forneça maiores detalhes a esse respeito.

Pouco antes da abertura da I Pré-Bienal, todos os artistas que haviam sido selecionados para a mostra foram convocados a enviar seus votos para o Júri de Seleção. Dessa vez, para o da IX Bienal de São Paulo. Dentre os quase 258 artistas, que apresentaram 1.300 obras, seriam escolhidos inicialmente 25 para a representação brasileira na mostra internacional $^{128}$. Por sugestão da AIAP foram convidados mais $5 \operatorname{artistas}^{129}$.

Os votos foram apurados no dia 31 de setembro de 1970: Lisetta Levi teve 56 votos e foi eleita. Mario Schenberg teve 15 votos (dois de Florianópolis e 13 de São Paulo) ${ }^{130}$. Depois da apuração, contudo, ainda chegaram alguns votos, sendo que 4 deles eram para o crítico, todos vindos do Recife, seu estado natal. Mesmo que tivessem sido contabilizados na apuração, não seriam suficientes para elegê-lo ${ }^{131}$.

O corpo de jurados da XI Bienal de São Paulo, que passava a ser internacional, teve a seguinte constituição: James Johnson Sweeney (Estados Unidos), Romero Brest (Argentina), Hugo Auler e Marc Bercowitz (indicados pela Fundação Bienal) e Lisetta Levi (eleita pelos artistas). Outra novidade foi a designação de um coordenador geral para a representação brasileira: Geraldo Ferraz.

A configuração final da representação nacional na XI Bienal foi a seguinte: 30 artistas selecionados na Pré-Bienal, aos quais se acrescentaram outros 60, distribuídos nas salas especiais "Vinte anos de Bienal", "Proposições" e "Didática da Gravura"132.

\footnotetext{
127 "Pré-Bienal começa no dia 12 com artistas de 21 estados". Nota divulgada à imprensa, datilografada, datada de 03/09/1970. Arquivo Histórico Wanda Svevo, Fundação Bienal.

128 "Regulamento da Pré-Bienal de São Paulo". Documento datilografado, datado de 20 de janeiro de 1970. Arquivo Histórico Wanda Svevo, Fundação Bienal.

129 "Júri já escolheu artistas brasileiros para a Bienal Internacional de Artes". Nota divulgada à imprensa. Documento datilografado, datado de 11/09/1970. Arquivo Histórico Wanda Svevo, Fundação Bienal.

${ }^{130}$ Segundo a apuração: Lisetta Levi (56 votos), Geraldo Ferraz (48), Morgan Motta e Maristela Tristão (21), Frederico Morais e José Geraldo Vieira (17), Oswald de Andrade Filho, Mário Barata e Quirino Campofiorito (16) e Mario Schenberg (15), outros nomes citados em ata receberam menos votos. Ata da apuração da eleição do representante dos artistas no Júri de Seleção da XI Bienal. Documento manuscrito, datado de 31 de agosto de 1970. Arquivo Histórico Wanda Svevo, Fundação Bienal.

${ }^{131}$ Cf. telegramas datados de 03 e 04/08/1970. Arquivo Histórico Wanda Svevo, Fundação Bienal.

132 "Relatório das Atividades em 1971". Documento datilografado, datado do mês de janeiro de 1972. Arquivo Histórico Wanda Svevo, Fundação Bienal.
} 
Por fim, é importante notar que o Ato Complementar 75 foi decretado semanas antes do término da X Bienal, o que aconteceu em 14 de dezembro de 1969. Por isso, é provável que, dois anos depois, esse impedimento já fosse de conhecimento público do meio artístico. Sabendo disso, os artistas poderiam ter redirecionado suas opções. Outra possibilidade para esse resultado seria a nova distribuição demográfica da eleição que, saindo do eixo Rio-São Paulo (no qual Mario Schenberg era mais conhecido), poderia ter influenciado o resultado.

\section{Mesa-Redonda da AICA: presença improvável}

Diante do que foi visto, é relevante notar que Mario Schenberg participou de uma Mesa Redonda de Críticos de Arte, mesmo sem ter feito parte do Júri de Seleção. Participaram do evento cerca de 120 convidados, entre críticos e artistas, representantes de 25 países $^{133}$. Novamente, os debates foram iniciados juntamente com a inauguração da XI Bienal de São Paulo, no dia 4 de setembro de 1971. Antônio Bento coordenou a participação brasileira na Mesa Redonda, enquanto Walter Zanini coordenou e secretariou os debates.

A crise da Bienal foi discutida a partir de um quadro mundial de declínio das grandes exposições internacionais ${ }^{134}$. Mais uma vez, a falta de uma direção artística (que já tinha sido apontada em 1969) foi criticada. Os temas dessa discussão foram a reformulação das bienais (novamente), a relação emergente da Arte com a Comunicação e com a Tecnologia. A fala de Mario Schenberg, gravada e transcrita, passou por esses três eixos. Sua comunicação ${ }^{135}$ é relevante para a compreensão de sua visão acerca dos temas já citados, pois foram tecidas ali relações conceituais que jogam luz sobre alguns aspectos que serão analisados em outro momento.

O crítico atribui a crise da Bienal a uma insistência na tradição museológica que, extremamente preocupada com os objetos, teria se tornado inadequada em vista da emergência de formas de expressão, cada vez mais ligadas à Arte Conceitual. Para ele, a “finalidade da arte é produzir valores, não objetos", embora o crítico reconheça que o objeto tem uma função importante na criação desses novos valores no caso das artes plásticas.

\footnotetext{
133 "Relatório das Atividades em 1971". Documento datilografado, datado do mês de janeiro de 1972. Arquivo Histórico Wanda Svevo, Fundação Bienal.

${ }^{134}$ ALAMBERT, Francisco \& Polyana CANHÊTE. Bienais de São Paulo: da era do museu à era dos curadores. São Paulo: Boitempo, 2004, p. 135.

135 "Mario Schenberg", documento datilografado, não datado, 7 páginas. Arquivo Histórico Wanda Svevo, Fundação Bienal.
} 
O crítico faz também, considerações a respeito da relação da arte com a Tecnologia e com a Comunicação, nas quais essas duas esferas surgem interligadas. Em linhas gerais, o deslocamento operado pela Arte Conceitual está profundamente ligado à crise de valores de uma civilização ocidental que tem na tecnologia um projeto industrial de produção de objetos (incluindo aí as obras de arte).

Ao contrário da arte ocidental, a arte oriental não se preocupava com isso. Fazendo referência ao pensamento estético chinês e a Kandinsky ${ }^{136}$, Mario Schenberg observou que, quando a arte passa a ser entendida como processo de comunicação, o objeto passa a ter seu justo estatuto, porquanto deixa de ser o ponto central da arte. Desse modo, a obra detém apenas papel instrumental, em lugar de ser a finalidade da criação artística: "ser obra de arte não é característica de um objeto, é função que pode ter"137.

A Arte Conceitual encontrava aí seu espaço de emergência, na medida em que vinha se tornando cada vez mais importante desde a segunda metade dos anos de 1960. Diante desse fato, já apontado na Mesa Redonda de 1969, o crítico reiterou sua recomendação: se a Bienal não se adaptasse a essa nova realidade da arte, estaria fadada a desaparecer.

Por fim, os impedimentos impostos a Mario Schenberg pelo Ato Complementar 75 pareciam indicar que o crítico não seria convidado para a Mesa Redonda pela Fundação Bienal. Por outro lado, se não lhe era possível uma atuação mais longa e remunerada, como era então a do corpo de jurados, não parecia haver entraves para sua participação pontual e voluntária no evento, uma vez que esse não tinha caráter acadêmico e estava fora de sua área na pesquisa científica. Essa é, todavia, apenas uma hipótese para explicar sua presença na mesa redonda da XI Bienal.

\section{Bienais de Ciência e Humanismo: ausência notável}

Se na Mesa Redonda de Críticos de Arte, foi a presença improvável de Mario Schenberg que chamou a atenção, nas Bienais de Ciência e Humanismo foi a ausência de um dos mais eminentes cientistas do país que se mostrou eloquente. Essa segmentação das bienais teve início em 1967, paralelamente à IX Bienal de Arte de São Paulo, projetada sob a forma de um Simpósio Mundial de Integração Ciência-Humanismo, do qual participaram cientistas

136 Trata-se do livro Do Espiritual na Arte, e na pintura em particular, do pintor Wassily Kandinsky (SCHENBERG, Mario. Diálogos com Mario Schenberg. São Paulo: Nova Sttela Editorial, 1985).

${ }^{137}$ Mario Schenberg. Transcrição de sua intervenção na Mesa Redonda de 1971. Documento não datado, p. 4. Arquivo Histórico Wanda Svevo, Fundação Bienal (foi mantida a grafia original do texto). 
do Brasil e do exterior. Os países participantes, entre eles Estados Unidos, França, Inglaterra, Israel e Alemanha, trouxeram exposições de divulgação tecnológica para integrar o evento.

Segundo Ciccillo Matarazzo, a finalidade da I Bienal de Ciência e Humanismo era "atrair para o nosso País a discussão dos temas científicos mais importantes da atualidade" "138. A idealização do certame teve em vista a integração entre as Artes e as Ciências, e foi a primeira do gênero na América Latina, gerando muita repercussão na época.

Os seminários internacionais trataram dos seguintes temas: 1) Ciências e humanidades: semelhanças e contrastes; 2) Influência recíproca das ciências e do humanismo na atualidade; 3) Difusão recíproca de conceitos humanísticos e científicos e, 4) Divulgação do conhecimento científico e humanístico. Ao público não especializado, estavam destinadas as exposições científicas, cuja finalidade era evidenciar o impacto do conhecimento científico na vida diária ${ }^{139}$.

A II Bienal de Ciência e Humanismo, em 1969, contou com três simpósios internacionais e um seminário nacional. Esse girou em torno do livro e da comunicação de massa, enquanto aqueles abordaram os seguintes temas: "transplantes de órgãos vitais"; "investigação clínica a respeito das úlceras de estômago e duodeno" e "aspectos humanísticos da ciência", que propunha um diálogo entre artistas, escritores e filósofos ${ }^{140}$. Entre os subtemas desse simpósio, estavam "a criatividade na ciência e nas artes" e a "humanização da ciência", temas muito caros a Mario Schenberg.

Foi organizada, também, a exposição “Átomos em Ação”, organizada pela Comissão de Energia Atômica dos Estados Unidos. Três edifícios foram construídos ao lado do pavilhão da Bienal para abrigá-la ${ }^{141}$. A partir de então, essa ramificação da Bienal passou a ter seu regulamento incluído no catálogo da exposição ${ }^{142}$.

${ }^{138}$ S. Paulo abrigará Bienal de Ciência. O Estado de São Paulo, 02/06/1967.

${ }^{139}$ S. Paulo abrigará Bienal de Ciência. O Estado de São Paulo, 02/06/1967.

${ }^{140}$ Cientistas e humanistas na Bienal de Ciências. Folha Ilustrada, 11/04/1969.

${ }^{141}$ Ciência \& Arte: X Bienal de São Paulo. Diário Popular, 19/10/1969.

${ }^{142}$ FUNDAÇÃO BIENAL. X Bienal. (catálogo de exposição) São Paulo: Fundação Bienal, 1969, p. 44 e 443. 


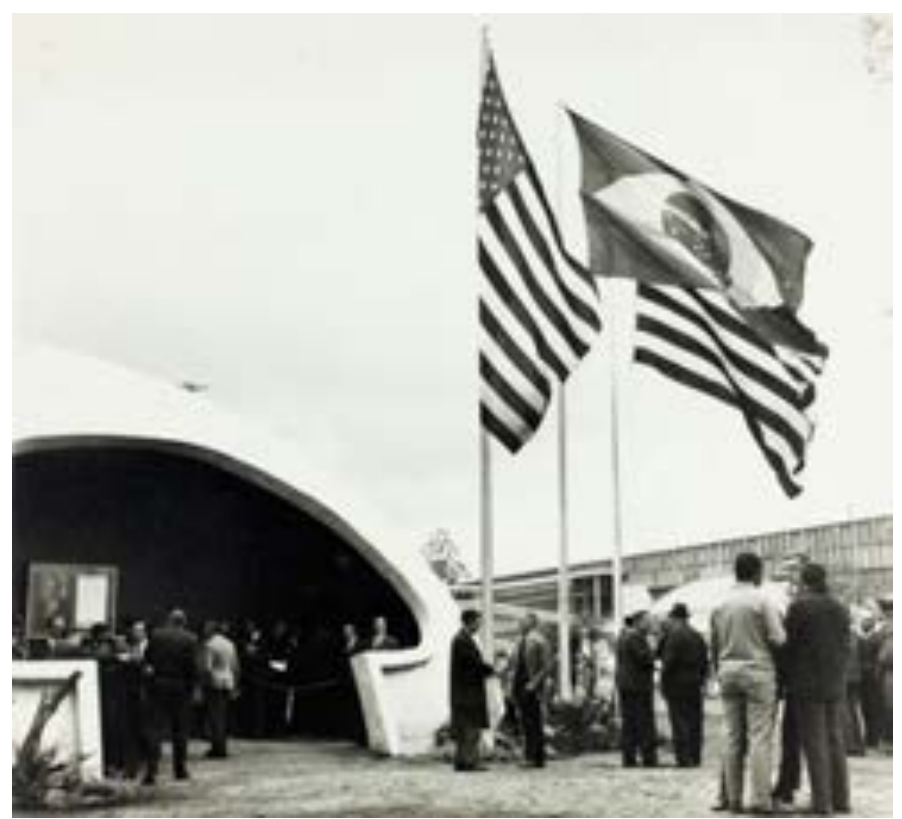

Figura 10 - X Bienal de São Paulo, em 1969. Em primeiro plano, estruturas temporárias, em forma de oca, construídas para abrigar os eventos da II Bienal de Ciência e Humanismo.

Por ocasião da III Bienal de Ciências e Humanismo, em 1971, foi criado um prêmio para a descoberta científica mais relevante, concedido ao pesquisador que desenvolveu a produção artificial de insulina, descoberta que beneficiou portadores de diabetes ${ }^{143}$. Foi realizado um simpósio internacional do qual participaram 26 convidados estrangeiros, incluindo o premiado ${ }^{144}$. Além disso, foram publicados, os Anais do Simpósio sôbre Ciência e Humanismo (grafia original), que contou com textos e resumos das conferências apresentadas na edição anterior ${ }^{145}$.

Ao longo das três edições que aconteceram dentro do período analisado, críticos de arte (como Vilém Flusser) e físicos brasileiros da Universidade de São Paulo (como José Goldenberg) tiveram voz nas Bienais de Ciência e Humanismo. Diante de tudo isso, cabe a seguinte questão: por que Mario Schenberg, físico teórico de carreira internacional e crítico de arte, que tinha tanto a contribuir nas discussões promovidas e, além de tudo, esteve envolvido na organização das Bienais de Artes Plásticas por toda a década de 1960, não tomou parte no evento, seja em sua organização, seja como convidado?

\footnotetext{
${ }^{143}$ FUNDAÇÃO BIENAL. XI Bienal. (catálogo de exposição) São Paulo: Fundação Bienal, 1971, p. 256-57.

144 "Relatório das Atividades em 1971". Documento datilografado, datado do mês de janeiro de 1972. Arquivo Histórico Wanda Svevo, Fundação Bienal.

${ }^{145}$ FUNDAÇÃO BIENAL DE SÃO PAULO. Anais do Simpósio sôbre Ciência e Humanismo. São Paulo: outubro de 1971. Foi mantida a grafia da época.
} 
É altamente provável que esse afastamento tenha ocorrido em decorrência do AI-5 e do Ato Complementar 75, que proibiam Mario Schenberg de atuar "como professor, funcionário ou empregado de estabelecimento de ensino público", bem como de "exercer, a qualquer título, cargo, função, emprego ou atividades, em estabelecimentos de ensino e em

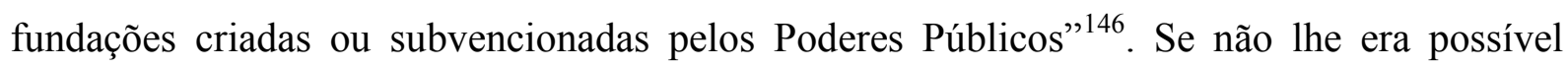
circular em campus universitários, nem utilizar suas bibliotecas, é plausível supor que também não fosse possível ao cientista tomar parte nas Bienais de Ciência e Humanismo. Isso porque esses eventos, além de serem levados a cabo por uma Fundação que recebia recursos municipais e estaduais, se configuravam como eventos científicos.

Há, no Arquivo Histórico Wanda Svevo, muita documentação a respeito da organização desses eventos, que não pôde ser estudada a fundo pelos seguintes motivos: primeiro, porque esse aspecto das Bienais não fazia parte do recorte delimitado, segundo, por falta de tempo. Em primeira análise, não foram encontrados indícios de que Mario Schenberg tenha tomado parte na organização dessas Bienais, nem participado como convidado. Fica aberto, todavia, um campo que poderá ser aprofundado no futuro.

De um lado, fica a dúvida sobre como Mario Schenberg participou da Mesa Redonda promovida junto à XI Bienal, mostra da qual estava impedido de se envolver como jurado. De outro, é a ausência do eminente físico teórico de renome internacional que surge com eloquência nas Bienais de Ciência e Humanismo, dada a proximidade física e intelectual do evento.

\section{Opiniões e Propostas}

\section{Opinião e Propostas 65}

Opinião 65 teve lugar no Museu de Arte Moderna do Rio de Janeiro, entre 12 de agosto e 12 de setembro de 1965. Foi organizada por Jean Boghici, proprietário da Galeria Relevo e marchand, e por Ceres Franco, crítica de arte que residia em Paris, de onde

\footnotetext{
${ }^{146}$ ATO Complementar $\mathbf{n}^{\mathbf{0}} \mathbf{7 5}$, de 21 de outubro de 1969, Diário Oficial da União, p. 8930. Disponível em: http://www.planalto.gov.br/ccivil_03/ACP/acp-75-69.htm Acesso em: 20/02/2013. Esse Ato Complementar foi assinado, por Luíz Antônio da Gama e Silva, que foi reitor da Universidade de São Paulo, tendo assinado também o AI-5, e por Antônio Delfim Neto, docente da Faculdade de Economia e Administração da USP. Agradeço ao Prof. Fr. Francisco Alambert pelo auxílio e pelas conversas a respeito do aspecto social e político desse período.
} 
colaborava com a imprensa brasileira e atuava discretamente como marchande. A proposta da exposição era reunir artistas residentes em Paris e no Brasil, promovendo um confronto entre a produção daqueles e a dos jovens artistas de vanguarda no país. Ambos tinham proximidade com a nova figuração, a Pop Art e o Nouveau Réalisme, e buscavam dar novo sentido e nova função à imagem ${ }^{147}$.

Da exposição, participaram 30 artistas, dos quais 13 eram estrangeiros, franceses ou residentes em Paris. Poucos desses artistas eram conhecidos no Brasil, com exceção de Juan Genovés e Manuel Calvo (espanhóis, este último residindo no país como bolsista do governo espanhol) e Alain Jaquet (francês). Entre os 17 artistas brasileiros, cuja maioria também era desconhecida do público, estavam Ângelo de Aquino, Adriano de Aquino, Pedro Geraldo Escosteguy, Antonio Dias, Gastão Manoel Henrique, Rubens Gerchman, Hélio Oiticica, Ivan Freitas, Ivan Serpa, Roberto Magalhães, Carlos Vergara, Vilma Pasqualini, Wesley Duke Lee, Flávio Império, José Roberto Aguilar, Waldemar Cordeiro (nascido em Roma) e Tomoshige Kusuno (de origem japonesa, que residia em São Paulo há cinco anos) ${ }^{148}$.

\footnotetext{
${ }^{147}$ A exposição foi "acompanhada de um cartaz em preto-e-branco, desenhado por Fernando Goldgaber, e teve como catálogo uma folha dobrada em quatro partes, trazendo a reprodução, em preto-e-branco, de dez obras, relação dos expositores, sem situar os números e os títulos dos trabalhos, e um texto de apresentação de Ceres Franco". MORAIS, Frederico. OPINIÂO 65: ontem e hoje. In GALERIA DE ARTE BANERJ. Ciclo de Exposições sobre Arte no Rio de Janeiro: 5. Opinião 65 (catálogo de exposição) Rio de Janeiro: Galeria de Arte Banerj, 1985, s/p.

${ }^{148}$ MORAIS, Frederico. OPINIÂO 65: ontem e hoje. In GALERIA DE ARTE BANERJ. Ciclo de Exposições sobre Arte no Rio de Janeiro: 5. Opinião 65 (catálogo de exposição) Rio de Janeiro: Galeria de Arte Banerj, 1985 , s/p. serão elencados, aqui, apenas os artistas brasileiros, foco do interesse nesta pesquisa.
} 


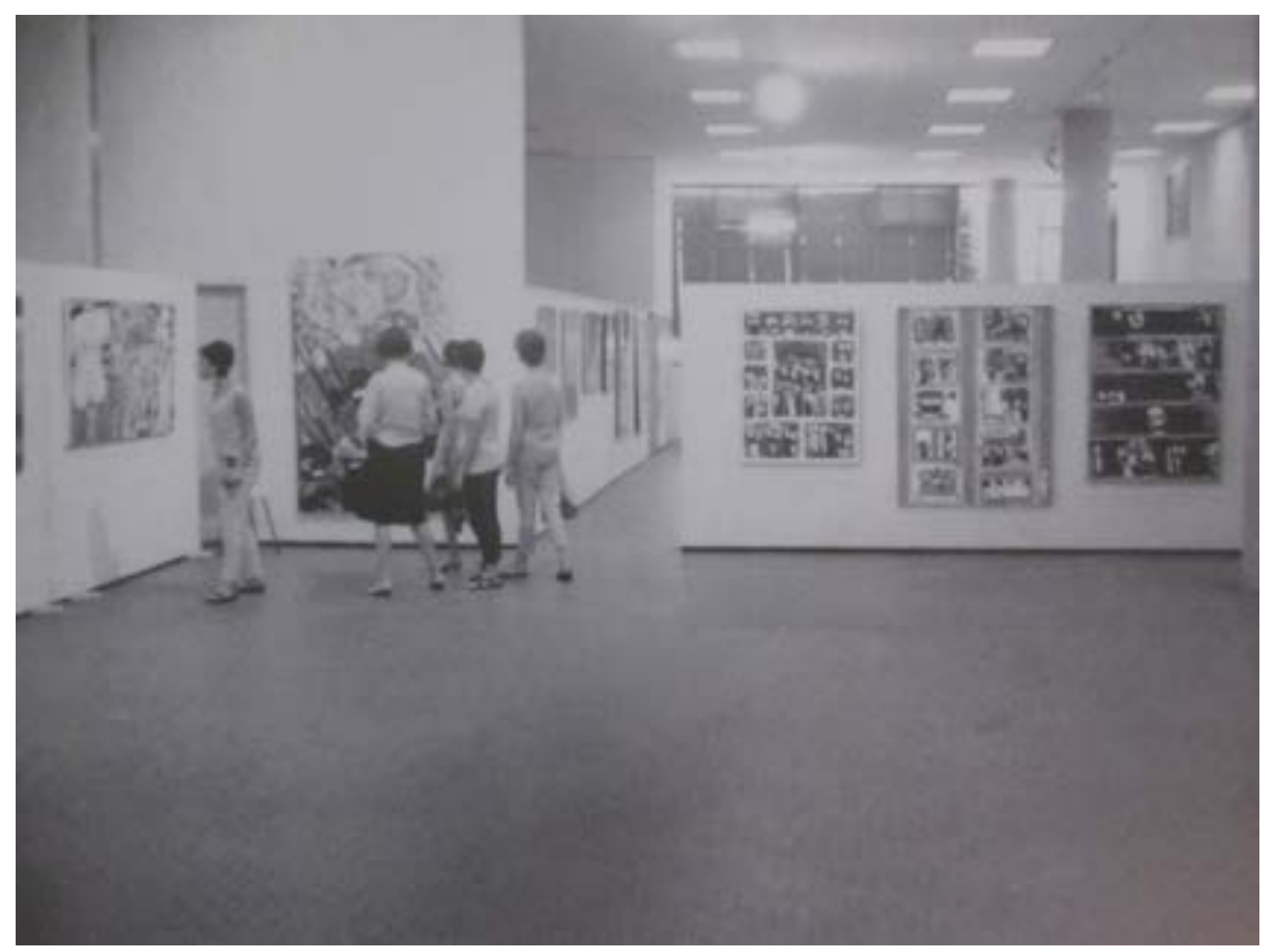

Figura 11 - Espaço expositivo de Opinião 65, no Museu de Arte Moderna do Rio de Janeiro. Agostosetembro de 1965.

O nome da mostra foi inspirado no show Opinião, do Teatro de Arena, que havia estreado em dezembro de 1964, marcando um posicionamento do teatro popular em relação ao contexto social e político decorrente da instauração do regime militar. No texto OPINIÂO 65: ontem e hoje, Frederico Morais observa que o show "fez muito sucesso e se transformou num grito de protesto, símbolo da reação de toda classe artística contra a censura, bandeira de luta de todos aqueles que procuravam reagir, em seus trabalhos, à ditadura militar" ${ }^{\text {149 }}$. Assim como o show Opinião no teatro, também os artistas reunidos por Ceres Franco no Brasil tinham, com a exposição Opinião 65 , o propósito de se manifestar com relação a essa nova realidade.

${ }^{149}$ MORAIS, Frederico. OPINIÂO 65: ontem e hoje. In GALERIA DE ARTE BANERJ. Ciclo de Exposições sobre Arte no Rio de Janeiro: 5. Opinião 65 (catálogo de exposição) Rio de Janeiro: Galeria de Arte Banerj, $1985, \mathrm{~s} / \mathrm{p}$. 
Frederico Morais observa, ainda, que essa dimensão marcadamente política da exposição foi ficando mais clara com o passar do tempo. Apesar de haver, da parte dos artistas brasileiros, a intenção de se manifestar frente à opressão cultural imposta pela censura, a mostra foi concebida inicialmente, como oportunidade de opinar sobre as artes plásticas. Desse modo, opinando sobre arte, os artistas se manifestavam sobre política.

No plano das artes plásticas, Opinião 65 foi a primeira elaboração consistente a fazer frente ao abstracionismo que dominava seu horizonte, tanto na vertente construtiva (Concretismo e Neoconcretismo, em nível nacional), quanto informal (action painting e tachismo, em nível internacional $)^{150}$. Os novos caminhos propostos pelos artistas brasileiros utilizavam elementos do Nouveau Réalisme europeu e da Pop Art norte-americana, na medida em que se voltavam à realidade imediata da vida diária. Não é por acaso que Ceres Franco, na apresentação de Opinião 65, a definiu como uma exposição de "ruptura com a arte do passado", e acrescentou:

${ }^{150}$ MORAIS, Frederico. OPINIÂO 65: ontem e hoje. In GALERIA DE ARTE BANERJ. Ciclo de Exposições sobre Arte no Rio de Janeiro: 5. Opinião 65 (catálogo de exposição) Rio de Janeiro: Galeria de Arte Banerj, $1985, \mathrm{~s} / \mathrm{p}$
VANÃRSKY * AGUILAR

ANTONIO DIAS * GENOVÉS

ADZAK * ESCOSTEGUY

ANGELO DE AQUINO * BERNI

WALDEMAR CORDEIRO * FOLDĖS

ROBERTO MAGALHÃES * TISSERAND

VERGARA * HELIO OITICICA

GAITIS * D'AQUINO

MACRÉAU * GERCHMAN

IVAN FREITAS * JARDIEL

IVAN SERPA * BERTINI

JACQUET * FLAVIO IMPERIO

GASTÃO HENRIQUE * TOMOSHIGE

VILMA PASQUALINI * CHRISTOFOROU

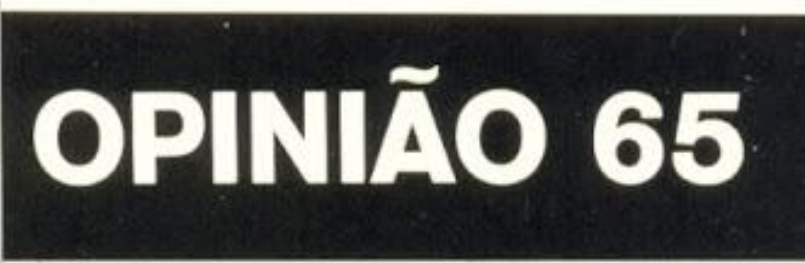

MUSEU DE ARTE MODERNA DO RIO DE JANEIRO

EXPOSIÇĀO COMEMORATIVA DO IV CENTENÁRIC

12 de agosto a 12 de setembro de 1965

Figura 12 - Convite original da exposição Opinião 65. 


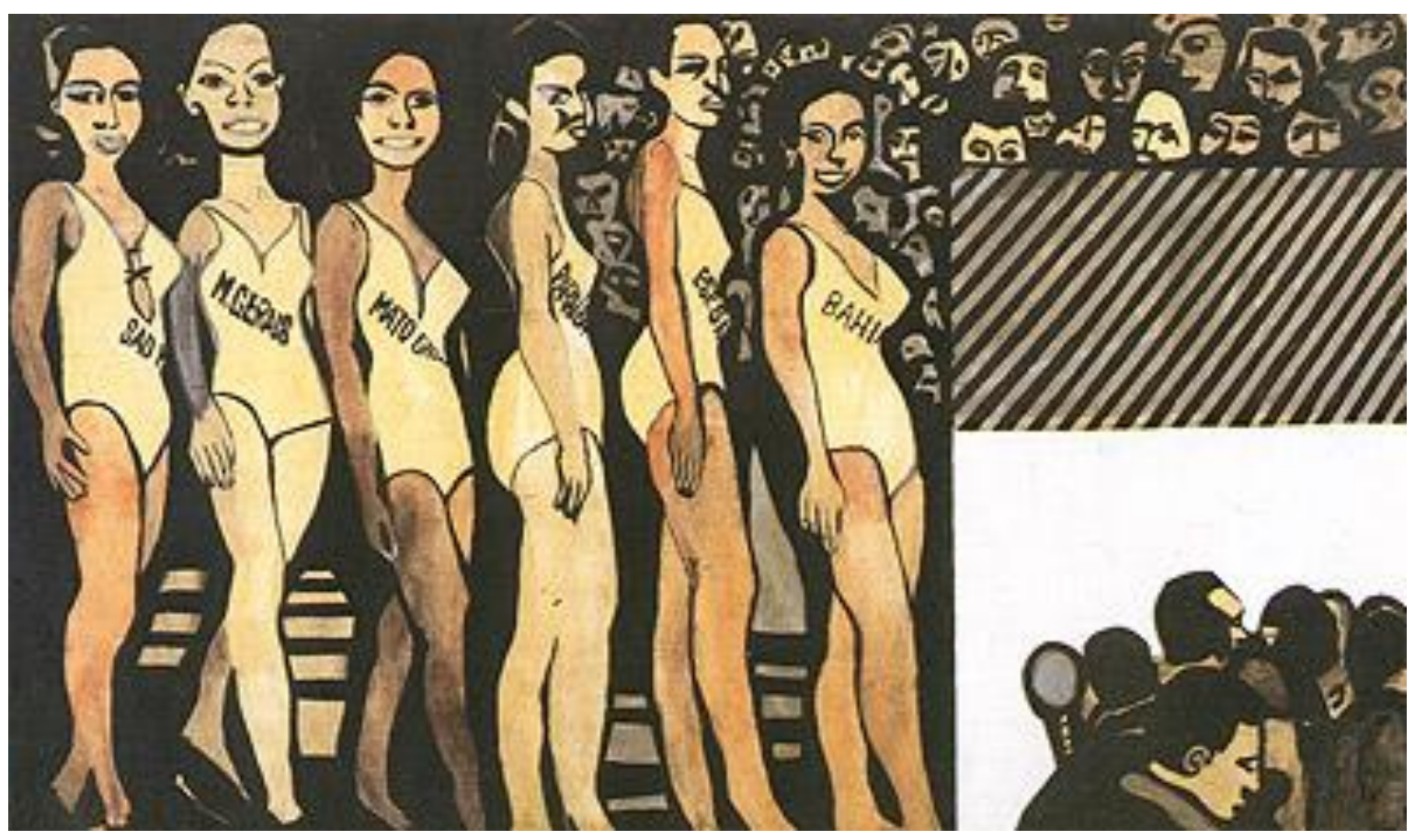

Figura 13 - Rubens Gerchman, Concurso de Miss, 1965, acrílica sobre tela, 140 x 280 cm. Coleção Gilberto Chateaubriand - MAM-RJ. Reprodução fotográfica autoria desconhecida.

"porque o artista hoje desempenhando um papel novo na sociedade, não aceita o tributo de uma tradição plástica caduca"151.

Pouco tempo depois, em São Paulo, foi inaugurada a exposição Propostas 65, no Museu de Arte Brasileira da Fundação Armando Álvares Penteado (MAB/FAAP) em 14 de dezembro, acompanhada de um seminário ${ }^{152}$. A mostra paulista foi a repercussão imediata de a exposição carioca e, reunindo muitos dos artistas participantes de Opinião 65 bem como críticos de arte, serviu para aprofundar os debates.

Aos artistas que expuseram em Opinião 65 (exceto Gastão Manoel Henrique, Hélio Oiticica, Ivan Freitas, Ivan Serpa, Carlos Vergara e Vilma Pasqualini, que não participaram da mostra paulista), juntaram-se Geraldo de Barros, Alice Brill, Dileny Campos, Míriam Chiaverini, Bernardo Cid, Enéas Dedecca, Waldomiro de Deus, Sérgio Ferro, Francisco Egas, Mona Gorovitz, Vera Ilce, Judith Luand, Nelson Leirner, Maurício Nogueira Lima, Fábio

${ }^{151}$ FRANCO, Ceres. Apresentação de “Opinião 65”. In GALERIA DE ARTE BANERJ. Ciclo de Exposições sobre Arte no Rio de Janeiro: 5. Opinião 65 (catálogo de exposição) Rio de Janeiro: Galeria de Arte Banerj, $1985, \mathrm{~s} / \mathrm{p}$.

${ }^{152}$ ITAÚ CULTURAL. Enciclopédia de Artes Visuais Itaú Cultural. Verbete Propostas 65. Disponível em: www.itaucultural.org.br Acesso em 09/08/2012. 
Magalhães, Antônio Maluf, Silvio Oppenhieim, Abraham Palatnik, Efísio Putzolu, Ubirajara Ribeiro, João Rossi e Luiz Sacilotto ${ }^{153}$.

Propostas 65 foi organizada pelo artista e teórico Waldemar Cordeiro, com a colaboração de Ângelo de Aquino ${ }^{154}$, sendo que ambos participaram também como expositores. Waldemar Cordeiro tomou parte, ainda, no seminário que a acompanhou, com o texto Todos Atentos ${ }^{155}$. Outros textos publicados na ocasião foram O Ponto Alto, de Mario Schenberg, Aula Maior, de José Geraldo Vieira, Realistas Zarolhos, de Ruben Martins e Vale Tudo de Sérgio Ferro. Acompanhados de imagens de algumas das obras que participaram da mostra, essas formulações foram publicadas na revista Artes $^{156}$. É importante destacar a proximidade de Mario Schenberg do contexto da vanguarda paulistana, tendo o crítico dado uma contribuição expressiva à feição que a arte de vanguarda tomava a partir desse momento, conforme será explicitado adiante ${ }^{157}$.

O período que teve início com Opinião 65 lançou as bases teóricas para a definição da vanguarda brasileira dos anos de 1960. Nesse ínterim, por meio dessas exposições conjuntas e seminários, artistas paulistanos e cariocas se aproximaram com mais intensidade. Segundo aponta Dasy Peccinini Alvarado, essas mostras constituíram “etapas sucessivas e fundamentais para a emergência da nova objetividade brasileira, uma tomada de posição comum de uma vanguarda nacional, cujo eixo era Rio-São Paulo" ${ }^{\text {158. }}$.

No Rio de Janeiro, os críticos Mário Pedrosa e Ferreira Gullar, junto dos artistas outrora ligados ao Grupo Neoconcreto, seguiam pela trilha aberta por esses desdobramentos que aliavam o fator construtivo à arte de participação, principalmente nos trabalhos de Lygia Clark e Hélio Oiticica.

Em São Paulo, Waldemar Cordeiro e Maurício Nogueira Lima vinham de um Concretismo rígido que, aliado a formulações do Nouveau Réalisme de Pierre Restany, com

\footnotetext{
${ }^{153}$ ITAÚ CULTURAL. Enciclopédia de Artes Visuais Itaú Cultural. Verbete Propostas 65. Disponível em: www.itaucultural.org.br Acesso em 09/08/2012.

${ }^{154}$ MORAIS, Frederico. OPINIÂO 65: ontem e hoje. In GALERIA DE ARTE BANERJ. Ciclo de Exposições sobre Arte no Rio de Janeiro: 5. Opinião 65 (catálogo de exposição) Rio de Janeiro: Galeria de Arte Banerj, $1985, \mathrm{~s} / \mathrm{p}$.

${ }^{155}$ CENTRO DE ESTUdOS DE ARTE CONTEMPORÂNEA. Arte em Revista, em 1979, ano I, nº. 2.

156 "Propostas 65". In Artes: São Paulo, 1966. Ano I, jan. p. 5-6. Posteriormente, os textos "O Ponto Alto" e "Vale Tudo" foram incluídos no dossiê "Opinião e Propostas da Vanguarda Brasileira", na publicação Arte em Revista, em 1979, ano I, no. 2. Nele, figuram também os textos "Opinião 65", de Ferreira Gullar (Revista Civilização Brasileira, $\mathrm{n}^{\circ}$. 4, setembro, 1965), bem como algumas das teses apresentadas no seminário Propostas 66, a saber, "Arte no Brasil", de Aracy Amaral, "Situação da Vanguarda Brasileira", de Hélio Oiticica, "Por que a Vanguarda Brasileira é Carioca", de Frederico Morais e "Opinião 65/66", de Mário Barata.

${ }^{157}$ Cf. ALVARADO, Daisy Valle Machado Peccinini de. Figurações Brasil Anos 60: Neofigurações Fantásticas e Neosurrealismo, Novo Realismo e Nova Objetividade. São Paulo: Itaú Cultural/Edusp, 1999.

${ }^{158}$ ALVARADO, Daisy Valle Machado Peccinini de. Figurações Brasil Anos 60: Neofigurações Fantásticas e Neosurrealismo, Novo Realismo e Nova Objetividade. São Paulo: Itaú Cultural/Edusp, 1999, p. 112.
} 
quem Cordeiro tinha contato, desembocaram na Arte Concreta Semântica, que tinha aproximação com a semiótica. Havia também um grupo de arquitetos, que ficaram conhecidos como Cinco Arquitetos Pintores - Ubirajara Ribeiro, Maurício Nogueira Lima, Flávio Império, Sérgio Ferro e Samuel Szpigel ${ }^{159}$-, que também desenvolviam pesquisas na linha da nova figuração. Nesse contexto, o Novo Realismo de Mario Schenberg veio enriquecer o horizonte desses artistas, além de ter tido peso na orientação da vanguarda nascente.

Além disso, esses dois núcleos tinham ambientações diferentes. O Rio de Janeiro, apesar da construção de Brasília, ainda era a capital funcional do país, sua ponte com o exterior era mais movimentada. Os artistas cariocas já tinham tido contato com os argentinos da outra figuración e os franceses da nouvelle figuration, da Escola de Paris, que marcou presença nas duas edições de Opinião.

São Paulo, por seu lado, tinha nas Bienais seu principal evento relacionado à difusão dos encaminhamentos mais recentes da arte. Já se sabe, contudo, que por diversas razões, o certame não garantia a efetivação de seu propósito básico: a máxima contemporaneidade. Por isso, alguns artistas e críticos que dispunham de mais abertura e informação tiveram um papel significativo na difusão desses novos direcionamentos, revelando as novas tendências e incentivando artistas mais jovens. Entre eles, destacam-se Walter Zanini, Mario Schenberg, Aracy Amaral, Waldemar Cordeiro e Wesley Duke Lee ${ }^{160}$.

Apesar dessas diferenças, para cariocas e paulistas era visível, naquele momento, uma mudança significativa na atitude fundamental dos artistas que se voltavam às novas figurações: os jovens artistas olhavam para o homem e para a realidade cotidiana em seus diversos aspectos. Ferreira Gullar, ao comentar Opinião $65^{161}$, contrapôs essa nova atitude de retorno à realidade à perspectiva formalista do abstracionismo, cuja preocupação seria lidar apenas com as qualidades plásticas da obra de arte.

$\mathrm{O}$ crítico viu com bons olhos o fato de que esses jovens traziam à tona uma arte interessada pelos problemas do homem e pelas coisas do mundo, expressa na conhecida frase: "Os pintores voltaram a opinar! Isto é fundamental" ${ }^{162}$. Gullar afirmou, ainda, não ter visto na exposição nenhuma obra-prima, embora reconhecesse que não era essa a preocupação da

${ }^{159}$ Em 1966, Mario Schenberg escreveu sobre eles um texto intitulado Cinco Arquitetos Pintores (Pensando a Arte. Nova Stella, 1988), no qual destaca a influência mútua entre eles, bem como os traços de cada um individualmente.

${ }^{160}$ ALVARADO, Daisy Valle Machado Peccinini de. Figurações Brasil Anos 60: Neofigurações Fantásticas e Neosurrealismo, Novo Realismo e Nova Objetividade. São Paulo: Itaú Cultural/Edusp, 1999, p. 98.

${ }^{161}$ GULLAR, Ferreira. Opinião 65. In CENTRO DE ESTUDOS DE ARTE CONTEMPORÂNEA. Arte em Revista, em 1979, ano I, n'. 2, p. 22-23.

162 GULLAR, Ferreira. Opinião 65. In CENTRO DE ESTUdOS DE ARTE CONTEMPORÂNEA. Arte em Revista, em 1979, ano I, no . 2, p. 22. 
maioria dos pintores brasileiros, o que não os impedia de transmitir sua visão de mundo por meio da arte que estavam fazendo.

Mário Pedrosa, por outro lado, gostou do que viu e chegou a apontar o alto valor do conteúdo plástico de algumas das obras expostas, embora esse aspecto fosse, também para ele, de menor importância frente às novas propostas trazidas por eles, mesmo que não fossem homogêneas esteticamente. Antes de serem importantes por esse motivo, ou pelas proposições técnicas nelas presentes, as obras eram “identificadas pela marca muito significativa de emergirem todos os seus autores de um meio social comum, por igual convulsionado, por igual motivado"163.

Dentro dessa nova atitude fundamental, empreendia-se a busca de uma comunicação mais direta com o público, a fim de dar conta dessa preocupação com a realidade. Nesse sentido, Sérgio Ferro observa que “[o]s problemas que a pintura nova examina são os do subdesenvolvimento, imperialismo, o choque direita-esquerda, o (bom) comportamento burguês, seus padrões, a alienação, a 'má-fé', a hipocrisia social, a angústia generalizada, [...]"164. Sendo assim, a unidade desse momento não deveria ser procurada nas técnicas, nos parentescos formais ou nos objetivos específicos desses artistas, mas no posicionamento contundente que tomavam diante da "situação abafante" com que se defrontavam, para usar as palavras do $\operatorname{artista}^{165}$.

Não sendo a unidade das proposições uma preocupação dos artistas, Propostas 65 não teve a intenção de ser homogenia, apresentando inúmeras técnicas, materiais, linguagens e visões de mundo ${ }^{166}$. Não se tratava de negar as técnicas modernas - que até pouco tempo antes constituíam a totalidade do repertório das artes plásticas, mas de incorporá-las a uma nova dimensão da criação, na qual figurem junto a outras possibilidades e linguagens. José Geraldo Vieira, nesse sentido, observou que essas exposições

não só mostram, acentuam e dão ênfase às técnicas modernas e aleatórias empregadas no suporte, na moldura, no plasma, no magma (nanquim, água-forte, aguada, óleo, resinas poliméricas, tintas acrílico-vinílicas, madeiras serragem, bronze, papel, pano, ferro, soldas, etc.), como ousam o emprêgo simultâneo de tais processos, gráfico-plásticos; e isso a ponto de ser difícil e obsoleto catalogar tais

\footnotetext{
${ }^{163}$ PEDROSA, Mário. Opinião... Opinião... Opinião... Mundo, Homem, Arte em crise. São Paulo: Perspectiva, 1975, p. 101.

${ }_{164}$ FERRO, Sérgio. Vale Tudo. In CENTRO DE ESTUdOS DE ARTE CONTEMPORÂNEA. Arte em Revista, em 1979, ano I, no. 2, p. 26.

${ }^{165}$ FERRO, Sérgio. Vale Tudo. In CENTRO DE ESTUDOS DE ARTE CONTEMPORÂNEA. Arte em Revista, em 1979, ano I, n'. 2, p. 26.

${ }^{166}$ FERRO, Sérgio. Vale Tudo. In CENTRO DE ESTUdos DE ARTE CONTEMPORÂNEA. Arte em Revista, em 1979, ano I, no. 2, p. 26.
} 
trabalhos nas chaves crônicas de pintura, desenho, gravura e escultura [...]. Sem ser preciso falar no abuso de colagens, montagens, fotografias, objetos e caligramas ${ }^{167}$.

Por aí, pode-se ter uma ideia da variedade de novas possibilidades técnicas acrescentadas às tradicionais. Waldemar Cordeiro observou, de modo preciso, que o novo sentido do realismo não significava um retorno ao realismo histórico, mas era consequência de todas as conquistas das vanguardas até aquele momento, inclusive das diversas tendências $\operatorname{abstratas}^{168}$.

Outra questão bastante discutida à época (embora não fosse inédita) diz respeito à influência internacional na arte brasileira, na medida em que as novas direções apontadas pela arte de vanguarda estavam no horizonte de tendências estrangeiras. Ferreira Gullar a formulou de maneira incisiva:

As fontes dessa arte são a pop art norte-americana e o novo realismo europeu? Seria simples afirmá-lo, sem discutir. Deve-se admitir que em alguns casos, essa afirmação é cabível. Noutros, não. Trata-se, de qualquer modo, de um movimento internacional, como esta exposição [Opinião 65] mesma o demonstra. Será, então, que mais uma vez as influências internacionais vêm interferir no processo artístico brasileiro? ${ }^{169}$

O próprio Gullar argumenta, logo em seguida, que uma arte pautada pela opinião e pelo senso crítico pode ser internacional sem anular os elementos de sua cultura local, regional, ou mesmo nacional. Afinal de contas, “[o]s problemas da linguagem pictórica são preocupação de uma minoria, mas a guerra, o sexo, a moral, a fome, a liberdade, são problemas de todos os seres humanos. Essa internacionalização é legítima” ${ }^{170}$.

Também para Waldemar Cordeiro, essa arte constituía uma vanguarda genuinamente nacional, pois em seu entender, não se estava diante da importação acrítica de um modelo ou estilo, mas de uma contribuição dialética viva entre os diversos países, mesmo os subdesenvolvidos. Nesse sentido, a vanguarda brasileira era, ao mesmo tempo, influenciada e influenciadora nesse circuito $^{171}$.

Para compreender esse ponto, é preciso ter em mente que, na segunda metade da década de 1950, o otimismo proveniente do plano de desenvolvimento do governo de Juscelino Kubitschek e da relativa estabilidade política do período configurou um terreno

\footnotetext{
${ }^{167}$ VIEIRA, José Geraldo. Aula Maior. Artes: Ano I, nº 3, jan. 1966.

${ }^{168}$ CORDEIRO, Waldemar. Todos Atentos. Artes: Ano I, no 3, jan. 1966.

${ }^{169}$ GULLAR, Ferreira. Opinião 65. In CENTRO DE ESTUDOS DE ARTE CONTEMPORÂNEA. Arte em Revista, em 1979, ano I, n'. 2, p. 23.

${ }^{170}$ GULLAR, Ferreira. Opinião 65. In CENTRO DE ESTUDOS DE ARTE CONTEMPORÂNEA. Arte em Revista, em 1979, ano I, no. 2, p. 23.

${ }^{171}$ CORDEIRO, Waldemar. Todos Atentos. Artes: Ano I, no 3, jan. 1966.
} 
propício para a arte concreta, fortemente pautada pela racionalidade e pela proximidade com a tecnologia $^{172}$. Já a década de 1960 viu a mudança de expectativa decorrente do regime militar, um dos motivos do teor de contestação que a arte do período veio a ter. Sobre isso, Mario Schenberg apontou que "a compreensão da arte como manifestação ideológica foi muito fraca tanto no concretismo quanto no neoconcretismo, em toda a década de cinquenta" (SCHENBERG, 1988, p.216), sendo que nos anos de 1960 retomou-se a consciência política com as tendências da nova figuração.

Após o debate abstração versus figuração, que marcou a tensão entre a arte concreta e o realismo regionalista social pregado pelo Partido Comunista nos anos de 1950, a década seguinte presenciou o enfraquecimento do abstracionismo geométrico e do expressionismo abstrato (até então, uma vedete internacional) em nome de desdobramentos mais próximos da Pop Art e do Nouveau Réalisme europeu, além das pesquisas dos artistas do Neoconcretismo, que desembocaram na Nova Objetividade Brasileira.

A partir da segunda metade da década de 1960 tornou-se evidente a constatação de que "o abstracionismo já deixou de ser a tendência dominante na Arte Contemporânea"173 , tanto no Brasil, como em nível internacional. Essa opção dos artistas, identificada como volta à figuração, foi devida à constatação de que, se as questões levantadas pela abstração (principalmente no Concretismo) estavam alinhadas com a expectativa da década anterior, os acontecimentos políticos dos anos de 1960 mudaram drasticamente essa situação.

O abandono da abstração estava envolvido nesse debate ideológico. O expressionismo abstrato, “que não tinha temas observáveis ou pontos de referência palpáveis, pôde se espalhar como uma pandemia cultural em todo o mundo, assumindo o 'dialeto' local onde quer que aparecesse" ${ }^{\text {174; }}$ e foi incentivado pelo governo dos Estados Unidos, cujo plano cultural fazia parte da polaridade em relação ao figurativismo da União Soviética. Ao lado desse fato, estava sua consolidação hegemônica diante da América Latina, estancada por regimes totalitários, e da Europa, enfraquecida em decorrência das Guerras Mundiais. Nesse contexto em que o centro do universo artístico tinha sido deslocado de Paris a Nova York, o expressionismo abstrato foi ao encontro do anseio de consolidação de uma hegemonia

\footnotetext{
${ }^{172}$ A arte concreta representou, até os anos de 1960, a principal alternativa à forte presença do realismo oficial, regionalista, propagado pela esquerda oficial do país. Essa era a orientação do Partido Comunista e também da academia, que já havia institucionalizado as vanguardas trazidas pelo Modernismo nas primeiras décadas do século XX (BRITO, Ronaldo. Neoconcretismo: Vértice e ruptura do projeto construtivo brasileiro. São Paulo: Cosac \& Naify, 1999).

${ }^{173}$ SCHENBerG, Mario. Pensando a Arte, São Paulo: Nova Stella, 1988, p179.

${ }^{174}$ WARHOL, Andy. Catálogo de exposição. Andy Warhol: Mr. América. Catálogo de exposição. São Paulo: Pinacoteca do Estado, 2010, p 11).
} 
cultural, não apenas em relação ao mercado de arte, mas também a uma posição de vanguarda quanto à produção de seus artistas ${ }^{175}$.

A política intervencionista dos Estados Unidos era vista com incômodo pelos artistas brasileiros e latino-americanos, que viviam sob regimes totalitários, constituindo um dos motivos que levou o expressionismo abstrato ao abandono. A liberação da abstração representava a tomada de posição em relação ao estado de coisas vigente no país e na América Latina ${ }^{176}$.

A necessidade de posicionamento e de denúncia da realidade pós-64 passou a ter muito peso na postura dos artistas da vanguarda brasileira. Sobre isso, Ferreira Gullar ${ }^{177}$, no texto Opinião 65, discorrendo sobre a exposição que empresta o nome ao artigo, afirmou que o abandono da abstração não foi imediato, nem isento de entraves e recuos.

Não se tratou, é claro, de afirmar categoricamente o desaparecimento do abstracionismo. Mas a constatação generalizada por parte da crítica e dos artistas foi de que essa vertente, como linha de condução de toda uma ambientação do cenário artístico que vigorou até o fim da década de 1950, já não apresentava mais caminhos a avançar em termos de experimentação e de novas possibilidades, pois não se mostrava como repertório adequado à intenção e às novas demandas sentidas pelos artistas naquele contexto histórico conturbado.

Nesse contexto, Mario Schenberg ${ }^{178}$ observou que o ano de 1965 marcou uma mudança profunda na arte brasileira. No texto $O$ Ponto Alto, já mencionado, o crítico fez pontuações a respeito da grande importância que tiveram as discussões e os debates promovidos por Propostas 65, o que representou um fato inédito na vida cultural de São Paulo.

\footnotetext{
${ }^{175}$ WARHOL, Andy. Catálogo de exposição. Andy Warhol: Mr. América. Catálogo de exposição. São Paulo: Pinacoteca do Estado, 2010.

${ }^{176}$ WARHOL, Andy. Catálogo de exposição. Andy Warhol: Mr. América. Catálogo de exposição. São Paulo: Pinacoteca do Estado, 2010.

${ }^{177}$ GULLAR, Ferreira. Opinião 65 (Revista Civilização Brasileira). In Arte em Revista (nº 2), São Paulo, CEAC, Maio-Agosto, 1979.

${ }^{178}$ SCHENBERG, Mario. O Ponto Alto. In Arte em Revista (n ${ }^{o}$ 2), São Paulo, CEAC, maio-agosto, 1979.
} 


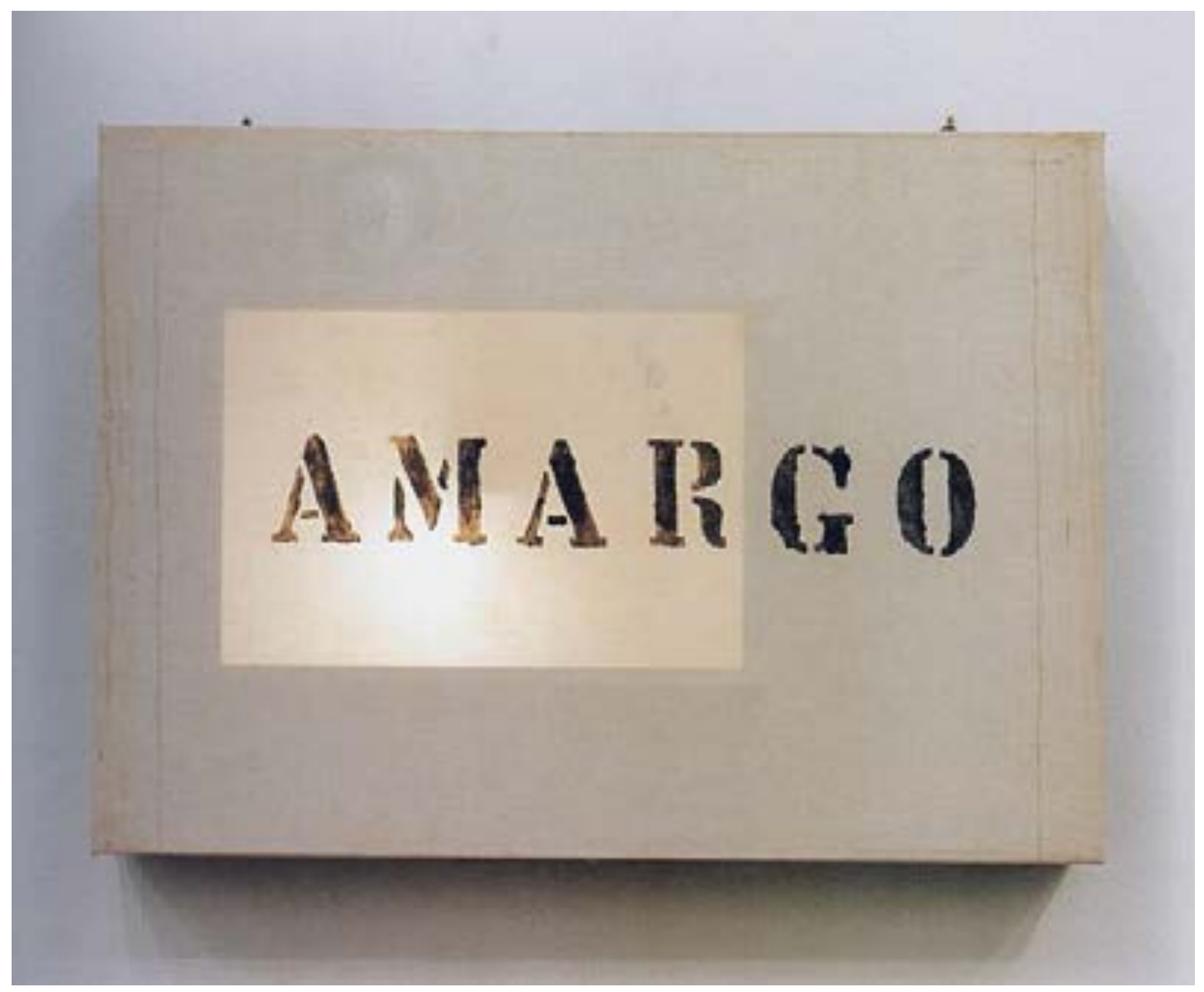

Figura 14 - Waldemar Cordeiro, Amargo, 1965, tecido e lâmpada, 20.5 x 28.3 x 3.9.

Levantando um aspecto que não foi mencionado por outras fontes analisadas, o crítico faz referência ao número reduzido de obras de cada artista: o contato com apenas três obras de cada um deles dificultava a compreensão das pesquisas individuais e a caracterização mais clara das diversas tendências realistas. Mario Schenberg sugere que, na edição posterior, esse número seja maior.

Assim como Waldemar Cordeiro, Mario Schenberg já reconhecia que, apesar de estarem sendo relegadas ao abandono, as tendências abstratas de fundo concretista foram importantes para o movimento artístico brasileiro, porquanto serviram para desembaraçá-lo de "formas anacrônicas de naturalismo e realismo" 179 . Longe de significarem um mero retorno ao realismo histórico, as tendências do novo realismo tornavam claro o fato de que, diante das

179 SCHENBERG, Mario. Pensando a Arte. São Paulo: Nova Stella, 1988, p. 179. Apesar de sua atuação política como militante do Partido Comunista, Schenberg se distanciou de sua orientação artística, a saber, o Realismo Socialista Soviético. Em lugar disso, o crítico apoiava as vanguardas emergentes na década de 1960 (e também posteriormente), pois elas estariam mais abertas às recentes demandas do momento histórico, podendo responder melhor ao desafio da descoberta de seus valores em gestação (SCHENBERG, Mário. O espaço social do Artista. Arquivo Centro Mario Schenberg de Documentação da Pesquisa em Artes. Texto datilografado, não numerado e não datado). 
conquistas das vanguardas históricas e das formas de abstracionismo mais recentes, era necessário pensar o sentido do realismo a partir de uma nova perspectiva.

Outro aspecto no qual o crítico aposta é que as novas formas de realismo realizem aquilo que as vanguardas construtivas não conseguiram: ajudar a definir a fisionomia cultural do país, como teria ocorrido nos Estados Unidos. E, mesmo lá, a Pop Art teria sido mais bem sucedida nesse aspecto.

Tendo diante de si o horizonte já contextualizado, Mario Schenberg esperava que, num futuro não muito distante, o país se conscientizasse de seus problemas fundamentais, bem como do importante papel que lhe caberia na construção de uma nova civilização mundial, tendo em vista o agravamento da crise das velhas estruturas nas quais estava pautado. Bem como a constatação de que não seria possível resolvê-la com base em soluções prontas vindas de países mais desenvolvidos. "Essa tomada de consciência", prossegue ele, "terá que se dar em todos os campos, principalmente o cultural. É inevitável que a criação artística realista, ligada a todos os aspectos da vida nacional, tenha uma função importante nesse processo"180.

Em face das mudanças recentes da realidade social e política do país, o novo realismo surgia como tentativa de dar conta dos novos horizontes - não necessariamente mais promissores - com os quais não só os artistas, mas todos os brasileiros tinham de lidar. Aos desmandos do regime militar sob o qual vivia o Brasil, se somavam preocupações de ordem internacional, como a ameaça de extinção da humanidade por meio de armas nucleares (que trazia consigo questionamentos a respeito dos rumos do desenvolvimento tecnológico) e a possibilidade de uma nova guerra mundial.

\section{Opinião e Propostas 66}

No ano seguinte, Opinião 66, também no MAM do Rio, abria entre 25 de agosto a 11 de setembro de 1966, a partir da iniciativa dos mesmos organizadores. Participaram da mostra, ao todo, 58 artistas, dos quais 20 eram brasileiros, a saber, Ângelo de Aquino, Dileny Campos, Lyigia Clark, Raul Cordula, Antonio Dias, Dionísio Del Santo, Pedro Geraldo Escosteguy, Rubem Gerchman, Gastão Manuel Henrique, Renato Landim, Francisco Liberato, Hélio Oiticica, Vilma Pasqualini, Glauco Rodrigues, Maria do Carmo Secco, Ivan

${ }^{180}$ SCHENBERG, Mario. Pensando a Arte. São Paulo: Nova Stella, 1988, p. 180. 
Serpa, Tereza Simões, Carlos Vergara, Carlos Zílio, Roberto Lanari e Ana Maria Maiolino (italiana residente no Rio de Janeiro) ${ }^{181}$.

Diante da repercussão de Opinião 65, a intenção de Jean Boghici e Ceres Franco era dar continuidade à mostra, tornando-a um certame anual. Mas a realização de sua segunda edição já mostrava as dificuldades desse plano. Sobre isso, Mario Pedrosa, escrevendo sobre essas exposições, observou que a Opinião de 1966 "apesar das excelentes obras ali apresentadas, já não tem a mesma frescura do primeiro" 182 .

Segundo Pedrosa, esse projeto partia de uma ideia na qual se chocavam dois critérios inconciliáveis: de um lado da balança, o critério da motivação inicial, de fundo extra-estético, que ia além dos valores puramente plásticos (movimentação vivida também pelo Cinema e pelo Teatro); do outro, pendia o critério de ordem apenas plástica que, com a repetição das mostras, acabaria por identificá-las aos salões anuais tradicionais. Tal repetição acabaria, inevitavelmente, esvaziando o "calor comunicativo social" da mostra; em decorrência do seguinte: um evento que se repete anualmente não pode se pretender eternamente um divisor de águas, uma manifestação de ruptura. No ano anterior, as motivações sociais de Opinião 65 estavam vivas para todos, artistas ou não. Já quando de sua segunda edição, esse calor da hora não estava mais presente na ordem do dia: a perplexidade dos primeiros momentos após o golpe militar já havia cedido lugar à constatação de uma nova realidade que, embora não menos opressiva, já era fato consumado ${ }^{183}$.

Em dezembro do mesmo ano, teve lugar o seminário Propostas 66, dessa vez na Biblioteca Pública Municipal - que seis anos antes recebera o nome do modernista Mário de Andrade $^{184}$. Entre as teses apresentadas, estão Arte no Brasil, de Aracy Amaral, Situação da Vanguarda Brasileira, de Hélio Oiticica, Por que a Vanguarda do Brasil é Carioca, de Frederico Morais e Opinião 65/66, de Mário Barata ${ }^{185}$.

\footnotetext{
$181 \mathrm{O}$ folheto da mostra reproduz algumas das obras em preto e branco, trazendo uma lista dos artistas e respectivas nacionalidades, frases de alguns deles sobre o caráter da mostra e uma pequena apresentação de Ceres Franco: "Opinião 65 suscitou uma reação assaz positiva da parte do público, da imprensa e dos artistas. Por essa razão, o MAM resolveu realizar 'Opinião 66' e estender seus convites a um grupo mais vasto de artistas representantes dessa corrente atual de vanguarda internacional”. MUSEU DE ARTE MODERNA - RJ. Opinião 66. (folheto de exposição). São Paulo, 1966. É interessante notar que, dessa vez, todos os artistas brasileiros eram cariocas ou residiam no Rio de Janeiro.

${ }^{182}$ PEDROSA, Mário. Opinião... Opinião... Opinião... Correio da Manhã, 11/09/1966. O texto foi republicado no livro Mundo, Homem, Arte em crise. (São Paulo: Perspectiva, 1975), no qual essa referência encontra-se na p. 100 .

${ }^{183}$ PEDROSA, Mário. Opinião... Opinião... Opinião... Correio da Manhã, 11/09/1966.

184 PREFEITURA DE SÃO PAULO. História da Biblioteca Mário de Andrade. Disponível em: http://www.prefeitura.sp.gov.br/cidade/secretarias/cultura/bma/historico/index.php? $\mathrm{p}=7653$ Acesso em: 01/02/2013.

${ }^{185}$ CENTRO DE ESTUDOS DE ARTE CONTEMPORÂNEA. Arte em Revista, em 1979, ano I, nº 2.
} 
Se no ano anterior, os artistas participantes de Opinião e Propostas estavam dando início a uma reflexão mais aprofundada sobre seu lugar nas novas tendências internacionais, em 1966 a situação havia mudado. Com a formulação mais delineada da feição da vanguarda brasileira, cujas pesquisas tendiam à desconstrução dos suportes tradicionais e ao objeto, as pinturas dos artistas franceses em Opinião 66 eram vistas como superadas. Essa exposição marcou a diminuição do interesse dos brasileiros pela Escola de Paris ${ }^{186}$.

Mário Barata expressou a intenção dos artistas das Opiniões (e, por extensão, das Propostas): segundo o crítico, as artes plásticas buscavam ter a proximidade e a penetração popular que o cinema, o teatro e a música popular tinham em relação ao grande público. Os artistas estavam à procura de meios mais eficazes para transmitir sua visão de mundo e estabelecer comunicação com o público em geral, a fim de vencer o restrito círculo da elite social e econômica que consumia e tinha contato com as artes plásticas ${ }^{187}$.

Desse modo, o retorno da figuração à ordem do dia se deflagrou em meio à busca de um fazer artístico que recuperasse o potencial de comunicação direta com o público, seja transmitindo mensagens, seja solicitando, por meio da participação na obra, a "contemplação de significados propostos na mesma"188, por meio de uma obra aberta.

Isso porque o alto teor de hermetismo que permeou as pesquisas do abstracionismo, tanto no concretismo, quanto no expressionismo abstrato, distanciou-a do público e dificultou uma relação direta e eficientemente comunicativa com o observador. É preciso lembrar, contudo, que isso foi devido ao fato de que o abstracionismo estava voltado à experimentação de ordem formal, no plano estético, e não â transmissão de mensagens no campo semântico como veículo para tomada de posição social e política.

A figuração, como recurso artístico, mostrou-se mais adequada para transmitir tais mensagens, tendo sido valorizada pelos artistas dos anos de 1960 e 1970 . Ferreira Gullar ${ }^{189}$ observou que,

\footnotetext{
${ }^{186}$ ALVARADO, Daisy Valle Machado Peccinini de. Figurações Brasil Anos 60: Neofigurações Fantásticas e Neosurrealismo, Novo Realismo e Nova Objetividade. São Paulo: Itaú Cultural/Edusp, 1999, p. 117.

187 BARATA, Mário. Opinião 65/66: artes visuais de vanguarda. In CENTRO DE ESTUDOS DE ARTE CONTEMPORÂNEA. Arte em Revista, em 1979, ano I, $\mathrm{n}^{\circ} .2$.

${ }^{188}$ OITICICA, Hélio. Esquema Geral da Nova Objetividade. In FERREIRA, Glória; COTRIM, Cecília (seleção e comentários). Escritos de artistas: anos 60/70. Tradução de Pedro Süssekind... et al. - 2. Ed. - Rio de Janeiro: Jorge Zahar Ed., 2009, p.163. O texto foi publicado originalmente no catálogo da exposição Nova Objetividade Brasileira (Rio de Janeiro: MAM, 1967).

${ }^{189}$ GULLAR, Ferreira. Opinião 65 (Revista Civilização Brasileira). In Arte em Revista (nº 2), São Paulo, CEAC, Maio-Agosto, 1979, p. 22.
} 
a tendência à abstração estava na raiz dessa arte que surge e se desenvolve com a Revolução Industrial, mas à margem dela. E assim, ora tendendo para o racionalismo mais radical, ora para o irracionalismo mais exacerbado, o pintor chegou ao esgotamento de uma visão de pintura: o automatismo tachista, os trapos e as "matérias" do informal. Àquela altura, as técnicas de pintar estavam liquidadas, bem como os critérios objetivos capazes de avaliar a qualidade da obra. Tampouco o artista sabia o que afirmava em seus quadros.

Diante do esgotamento não apenas do abstracionismo, mas também do sentido das vanguardas históricas, o caminho para fora do impasse se deu com o resgate da figuração. É claro que várias das questões postas por aquelas vanguardas continuaram a reverberar: a Pop Art e o Nouveau Réalisme, por exemplo, recuperaram questões e procedimentos do Dadá 190 . Pode-se perceber, por meio dos textos críticos da época, que o ambiente artístico no país, em face das novas possibilidades abertas com o retorno da figuração, teve momentos de uma liberdade de pesquisa, ao que parece, nunca antes vista: "O artista hoje faz o que quer, mais liberdade criativa não é possível"191.

Em meio a esse contexto, com exceções como Aracy Amaral (que não via no país a possibilidade de haver vanguarda, pois entendia que não havia núcleos artísticos densos o bastante para fornecer elementos de fato inovadores) ${ }^{192}$, artistas e críticos tendiam a ver na vanguarda brasileira uma contribuição original à arte em nível internacional, porquanto pareciam concordar que, apesar da influência internacional, os artistas brasileiros tinham sido capazes de aliar esse arcabouço às suas premissas próprias e às peculiaridades da realidade nacional.

Diferentemente do ano anterior, Mario Schenberg não publicou entre os participantes de Propostas 66, o que não quer dizer que estivesse menos próximo do que se passava então no circuito das artes plásticas. Nesse momento, manteve proximidade tanto com os artistas cariocas quanto com os paulistas, tendo escrito sobre duas outras exposições coletivas bastante relevantes. A Exposição do Grupo Neo-Realista ${ }^{193}$ trata da exposição inaugural da Galeria G4, da qual participaram os artistas cariocas, Antônio Dias, Rubens Gerchman, Roberto Magalhães, Pedro Escosteguy e Carlos Vergara. Em São Paulo, os arquitetos Ubirajara Ribeiro, Maurício Nogueira Lima, Flávio Império, Sérgio Ferro e Samuel Szpigel

\footnotetext{
${ }^{190}$ ARCHER, Michael. Arte Contemporânea. São Paulo: Martins Fontes, 2008, $2^{\text {a }}$ Edição.

191 OITICICA, Hélio. Situação da Vanguarda no Brasil. In CENTRO DE ESTUDOS DE ARTE CONTEMPORÂNEA. Arte em Revista, em 1979, ano I, nº. 2, p. 31.

${ }^{192}$ AMARAL, Aracy. Arte no Brasil. In CENTRO DE ESTUDOS DE ARTE CONTEMPORÂNEA. Arte em Revista, em 1979, ano I, n ${ }^{\circ} .2$, p. 29.

${ }^{193}$ SCHENBERG, Mario. Pensando a Arte. São Paulo: Nova Stella, 1988, p. 181.
} 
participaram da mostra sobre a qual Mario Schenberg escreveu o texto Cinco Arquitetos Pintores $^{194}$.

Aos olhos de Mario Schenberg, ambas as exposições foram demonstrações bastante animadoras da vitalidade da arte brasileira. A mostra na Galeria G4 the causou "uma impressão extremamente favorável de poder criativo e de renovação da arte brasileira" "195, ao passo que os cinco arquitetos de São Paulo davam a ver o papel "cada vez mais destacado do movimento artístico paulistano"196 . O crítico fez considerações a respeito da interação entre os artistas dos dois núcleos, e também sobre a trajetória artística de cada um em particular.

Em seu entender, as tendências neo-realistas desempenhariam um papel importe não apenas no campo artístico e cultural, como também em setores mais amplos de toda a vida nacional, porquanto se configurava como uma arte de crítica social e política. Nesse sentido, o neo-realismo, em suas diversas vertentes, poderia "se tornar um fator significativo para a elevação da consciência de amplos setores da nossa população e a influir cada vez mais no debate e na solução dos grandes problemas nacionais"197.

A partir das reflexões suscitadas por essas manifestações - Opiniões e Propostas, além das mostras da Galeria G4 e dos Cinco Arquitetos Pintores -, bem como pelas Bienais de São Paulo, Mario Schenberg chegou, no texto Um Novo Realismo ${ }^{198}$, à sua formulação dessa tendência, ainda no mesmo ano.

Durante a década de 1970, dispondo de mais tempo para se dedicar à crítica de arte, Schenberg exerceu essa atividade com maior intensidade. Datam dessa época vários de seus estudos e textos para catálogos. Publicou, em 1973, um estudo intitulado "Arte e Tecnologia" no livro Arte Brasileira Hoje, organizado por Ferreira Gullar, e outro sobre os movimentos concreto e neoconcreto na revista Arte Hoje em $1977^{199}$, que serão analisados no capítulo seguinte.

Mesmo afastado do ambiente universitário, Schenberg publicou alguns estudos sobre teoria da relatividade geral em revistas científicas nacionais e internacionais. Sobre isso, o

\footnotetext{
${ }^{194}$ SCHENBERG, Mario. Pensando a Arte. São Paulo: Nova Stella, 1988, p. 187. Note-se, nesse texto, que onde se lê Samuel Spiegel, deve-se ler Samuel Szpigel.

${ }^{195}$ SCHENBERG, Mario. Pensando a Arte. São Paulo: Nova Stella, 1988, p. 182.

${ }^{196}$ SCHENBERG, Mario. Pensando a Arte. São Paulo: Nova Stella, 1988, p. 187.

${ }^{197}$ SCHENBERG, Mario. Pensando a Arte. São Paulo: Nova Stella, 1988, p. 198.

${ }^{198}$ SCHENBERG, Mario. Pensando a Arte. São Paulo: Nova Stella, 1988, p. 185.

199 AJZENBERG, Elza. Mario Schenberg - O Crítico. In AGUILAR, José Roberto. O mundo de Mario Schenberg. São Paulo: Casa das Rosas, 1996, p. 26.
} 
cientista afirmou: "tenho trabalhado com uma certa dificuldade nos últimos anos, por falta de biblioteca e revistas. Isso realmente tem me atrapalhado bastante" ${ }^{, 200}$.

Em 1982, com a Lei da Anistia, retornou à universidade de São Paulo, mas não como professor titular, a fim de poder atuar com liberdade de ensino e pesquisa. No primeiro semestre do ano seguinte, ministrou, no Departamento de Física, a disciplina "Evolução dos Conceitos da Física", cujas gravações das aulas, feitas por um grupo de alunos, originaram o livro Pensando a Física, no qual Mário Schenberg expôs sua visão a respeito da História e da Filosofia da Ciência ${ }^{201}$.

Nesse período conturbado da história brasileira, Schenberg não deixou de se posicionar em relação à arte, à política e aos rumos da ciência e do ensino universitário no país, mesmo com os problemas que a perseguição política impôs. Essas duas décadas tiveram momentos dramáticos, mas foram imensamente produtivas.

${ }^{200}$ SCHENBERG, Mario. Entrevista com Mário Schenberg. In Revista Brasileira de Ensino de Física, pt. 1 vol. 1, n 2, 1979. (Entrevista publicada inicialmente no jornal O Estado de São Paulo, edição de 10/12/1978), p. 68. Disponível em: http:/www.sbfisica.org.brirbefpdffvol01a18.pd Acesso em 16/02/2012.

${ }^{201}$ AGUILAR, José Roberto. O mundo de Mario Schenberg. São Paulo: Casa das Rosas, 1996 e GOLDFARB, José Luiz. Voar também é com os Homens. São Paulo: EDUSP, 1994. 


\section{Schenberg e Vanguardas: um novo humanismo}

O espaço da arte de uma época é talvez menos concreto que o espaço humano social e histórico contemporâneo, mas possivelmente mais rico porque inclui também de certo modo as fantasias da vida interior ${ }^{l}$.

Mario Schenberg

A mente intuitiva é uma benção sagrada e a mente racional, um servo fiel. Criamos uma sociedade que honra o serviço e que esqueceu a bênção ${ }^{2}$.

Albert Einstein

\section{Novo Humanismo e Novo Realismo}

José Luiz Goldfarb, no livro Voar também é com os homens, fez importantes considerações sobre as características dos textos críticos de Mario Schenberg, apontando a surpreendente densidade de seu discurso:

Cada uma de suas observações era concentrada, e, aos poucos, ela atingia uma reflexão complexa e cheia de significados, sentindo-se distante dos rigores da universidade e das publicações científicas MS [Mario Schenberg] arrisca considerações filosóficas sem o rigor da prova e do desenvolvimento disciplinado. $\mathrm{O}$ descobridor de neutrinos nas estrelas cede lugar a um crítico especulativo que não quer mais apresentar um pensamento encadeado, com começo, meio e fím, o crítico especulativo terá a liberdade de produzir frases densas, quase independentes. Pensamentos completos que, por si sós, nos obrigam a refletir. Suas "críticas" são claramente abertas, plenas de possibilidades e desenvolvimentos ${ }^{3}$.

\footnotetext{
${ }^{1}$ SCHENBERG, Mario. Arte e tecnologia. In GULLAR, Ferreira \& PEDROSA, Mário. Arte brasileira hoje: situação e perspectivas. Rio de Janeiro: Paz e Terra, 1973, p 93.

${ }^{2}$ COHEN, Marilene. Albert Einstein. Col. Personagens que marcaram época. São Paulo: Globo, 2007.

${ }^{3}$ GOLDFARB, José Luiz. Voar também é com os Homens. São Paulo: EDUSP, 1994, p. 129. A fim de esclarecer o uso das aspas quando se refere aos textos críticos de Mario Schenberg, observa-se que o autor assim o fez em observação ao fato de o crítico-cientista não ter se considerado um crítico de arte, e não por
} 
Cada frase de seus textos críticos é repleta de vivências e da complexidade do pensamento do crítico-cientista; cada análise, repleta de aberturas, direcionamentos e interpretações. Ao tecer suas críticas, Mario Schenberg também criava algo novo, a partir da obra de arte, de seu conhecimento do artista que a elaborou e de si mesmo. Sua crítica de arte era também criativa e criadora. Criativa, pois ia além de uma interpretação da obra a partir de uma perspectiva normativa; criadora, pois fornecia ao artista novos horizontes para seu desenvolvimento artístico ao revelar, muitas vezes, aspectos dos quais o próprio artista não havia tomado consciência ${ }^{4}$.

Diante disso, mostrou-se necessário esclarecer que a análise a seguir não teve a pretensão de esgotar toda a dimensão ou as possíveis e variadas direções de interpretação de sua "crítica aberta". Também não se pretendeu explorar possíveis relações entre o pensamento de Mario Schenberg e outros autores que trataram do Novo Humanismo à época. Serão apontadas apenas os referenciais que surgiram durante esta pesquisa, deixando em aberto um amplo campo de estudo no que se refere à continuidade da pesquisa acerca do pensamento de Mario Schenberg. Assim, procurou-se evidenciar a relação entre sua concepção de um Novo Realismo e o Novo Humanismo, e não adentrar o universo de interpretações possíveis dos textos do crítico.

Outro aspecto apontado pelo autor a respeito da personalidade do critico foi a importância do diálogo no movimento de seu pensamento. Mario Schenberg estava interessado no movimento de reflexão que, expresso oralmente, poderia surpreender ao revelar novos aspectos de uma ideia, mesmo uma já bastante abordada. Para Schenberg, o pensamento era criativo na fala, enquanto o texto escrito apresentava-se fechado e imóvel ${ }^{5}$.

Por isso, o crítico não tinha muito interesse em registrar por escrito suas reflexões filosóficas, que podem ser encontradas com mais frequência em entrevistas e livros como Diálogos com Mario Schenberg (São Paulo: Nova Stella, 1985), por exemplo, elaborados a partir de gravações de sua fala. A marca da oralidade está presente de modo notável nas

desconsiderar sua qualidade. Neste estudo, por outro lado, não se utiliza esse procedimento, pois se considera como legítimo seu estatuto de Mario Schenberg enquanto crítico de arte.

${ }^{4}$ LIMA, Maurício Nogueira. Mário Schenberg: incentivador e crítico. In AJZENBERG, Elza (org.). Schenberg - Arte e Ciência. São Paulo, 1995, p. 42; TOLEDO, Amélia. Amélia Toledo. In AJZENBERG, Elza. In Shenberg: Arte e Ciência. São Paulo: ECA/USP, 1997, p. 36-7.

5 "Por muitas vezes, MS [Mario Schenberg] citava Buda, Sócrates e Jesus como exemplos de grandes pensadores que não escreveram. MS sempre valorizou a criação acima da repetição" (GOLDFARB, José Luiz. Voar também é com os Homens. São Paulo: EDUSP, 1994, p.57). 
análises que Schenberg fez de artistas e tendências que, apesar de datilografadas pelo próprio crítico, procuram manter o instante vívido de sua reflexão ${ }^{6}$.

A cosmovisão do Professor Schenberg mobilizava um amplo horizonte de referenciais conceituais, como o Marxismo, com o qual teve contato ainda na juventude, por meio do qual percebeu que a História tinha também uma dimensão teórica, não sendo apenas uma sucessão de acontecimentos ${ }^{7}$. Sobre isso, o crítico relata:

\begin{abstract}
A primeira filosofia que entrei em contato foi o marxismo, não era um marxismo muito aprofundado, mas, enfim, tomei conhecimento quando estava no último ano do curso secundário. Um colega deu-me um número de uma revista que se chamava Cultura, editada pelo Mangabeira no Rio de Janeiro, se não me engano. [...] Com o marxismo verifiquei que também na História poderia haver uma espécie de teoria, que a História não era simplesmente uma mera acumulação de fatos sem nexo.
\end{abstract}

Outro marco conceitual foi o inconsciente coletivo de Carl $\mathrm{Jung}^{8}$, que pode ser definido como o nível mais profundo da psique, composto por substratos que foram herdados. Esses conteúdos seriam comuns a todos os seres humanos e sua manifestação se daria por meio de imagens - não necessariamente visuais - denominadas pelo psiquiatra suíço de arquétipos. Estes seriam, por sua vez, a expressão funcional do conteúdo presente no inconsciente coletivo ${ }^{9}$.

Foi possível notar que, para o Professor Schenberg, se a descoberta do inconsciente por Sigmund Freud representou a ampliação das fronteiras da vida mental do homem em nível individual, o inconsciente coletivo junguiano expandiu ainda mais esse território, porquanto permitiu a Schenberg conceber, na história da cultura, a manifestação de estruturas fundamentais ${ }^{10}$.

Também o pensamento e a arte do Oriente foram muito caros ao crítico e marcaram sua visão de mundo. No início da década de 1940, Schenberg viajou para os Estados Unidos como pesquisador, onde teve contato com a filosofia oriental. Além dos conceitos de Ying e Yang, que descobriu com Wolfgang Pauli, o crítico encontrou um livro de Oswald Síren, grande conhecedor de arte chinesa ${ }^{11}$.

\footnotetext{
${ }^{6}$ Adiante, serão aprofundadas as considerações acerca da crítica de arte de Mario Schenberg.

${ }^{7}$ SCHENBERG, Mario. Diálogos com Mario Schenberg. São Paulo: Nova Stella, 1988, p. 21.

${ }^{8}$ Cf. JUNG, Carl. Tipos Psicológicos (Rio de Janeiro: Zahar Editores, 1974) e Memória, Sonhos, Reflexões (Rio de Janeiro: Nova Fronteira, 1970).

${ }^{9}$ JUNG, Carl. Tipos Psicológicos (Rio de Janeiro: Zahar Editores, 1974) e Memória, Sonhos, Reflexões (Rio de Janeiro: Nova Fronteira, 1970).

${ }^{10}$ GOLDFARB, José Luiz. Voar também é com os Homens São Paulo: EDUSP, 1994.

${ }^{11}$ SCHENBERG, Mario. Diálogos com Mario Schenberg. São Paulo: Nova Stella, 1988, p. 31.
} 
Tratava-se de uma compilação de textos chineses tradicionais sobre pintura e arte, que marcou a visão de Mario Schenberg, abrindo-lhe um novo horizonte conceitual. Sobre isso, Schenberg observou o seguinte:

\begin{abstract}
Esse livro foi extremamente importante para minha formação de crítico de arte e para a introdução à filosofia chinesa em geral. [...] Foi um dos livros que mais me marcaram, onde prendi muito. [...] Ele recolheu todos os textos clássicos a respeito da pintura chinesa, e isso para mim abriu todo um horizonte conceitual e filosófico que não só iluminou o problema da relação entre arte e filosofia, como também toda a cultura chinesa ${ }^{12}$.
\end{abstract}

Logo após esse relato, o crítico recordou que, infelizmente, perdera o livro de Oswald Síren e não encontrou outro exemplar ${ }^{13}$. De acordo com as pistas dadas no depoimento analisado, a saber, que o livro fora editado em Pequim antes da guerra, foi possível identificar essa referência, a respeito da qual o crítico não se recordava, na ocasião, de outras informações.

Oswald Síren (1879 - 1966) foi um historiador da arte finlandês ficou conhecido por ter sido um dos primeiros ocidentais a estudar e colecionar arte do Oriente, principalmente chinesa. O livro ao qual Mario Schenberg se referiu intitula-se The Chinese on the Art of Painting: Translations and Comments (Benjing: H. Vetch, 1936), e foi o único do autor publicado na China. A obra não foi traduzida para o português, mas existe uma segunda edição, publicada na década de 1960 (New York: Schocken Books, 1963) ${ }^{14}$. Conforme pontuou o crítico, trata-se de uma obra considerada rara e difícil de ser encontrada.

Outras fontes mobilizadas por Mario Schenberg a respeito da arte e do pensamento do Oriente foram as obras The Tao of Painting - a study of the ritual disposition of Chinese painting (Londres: Routledge \& K. Paul 1957) e Dialogue avec Le visible (Paris: Flamarion, 1955), de René Hyugue ${ }^{15}$.

No campo da história da ciência, começavam a ser feitas revisões que o Professor Schenberg considerava importantes. Autores como Henri Poincaré e Albert Einstein apontavam que a lógica e a razão eram, sem dúvida, importantes na demonstração e na operacionalização das descobertas cientificas, mas a intuição e a imaginação é que permitiam

12 SCHENBERG, Mario. Diálogos com Mario Schenberg. São Paulo: Nova Stella, 1988, p. 31.

13 "Infelizmente, perdi esse livro e não tenho nenhuma cópia porque foi editado em Pequim antes da guerra. Era um livro magistral, e embora creia que deva haver alguma tradução disponível, não tive mais notícias dele". SCHENBERG, Mario. Diálogos com Mario Schenberg. São Paulo: Nova Stella, 1988, p. 31.

14 LEE, Sorence. Oswald Síren. In Dictionary of Art Historians. Disponível em: http://www.dictionaryofarthistorians.org/sireno.htm Acesso em 07/05/2013.

${ }^{15}$ F. SCHENBERG, Mario. Diálogos com Mario Schenberg. São Paulo: Nova Stella, 1988. Em momento oportuno, essas referências serão mobilizadas também neste estudo, a fim de evidencias aspectos do pensamento e da arte do Oriente na crítica de arte de Mario Schenberg. 
criar. Tendo em vista essas referências, Schenberg desenvolveu sua concepção a respeito da importância da intuição como elemento criativo tanto na ciência, quanto na arte ${ }^{16}$.

Tendo em vista os elementos da cosmovisão e da crítica de arte de Mario Schenberg, tornou-se possível analisar a concepção do crítico acerca do Novo Realismo, bem como sua relação com o Novo Humanismo. No texto Um Novo Realismo, de 1966, o crítico de arte Mario Schenberg pontuou que

em 1965, o novo realismo nas artes plásticas adquiriu no Brasil a repercussão que alcançara dois ou três anos antes nos maiores centros mundiais. O surto do movimento foi marcado pelas exposições "Opinião 65", na Guanabara, e "Propostas 65", em São Paulo, assim como pela premiação de Wesley Duke Lee, em Tokyo, e de Antônio Dias e Roberto Magalhães, em Paris. Assim, o novo realismo brasileiro já se apresenta como corrente artística de significação internacional. ${ }^{17}$

Mesmo contendo os traços de sua filiação internacional, o Novo Realismo manifestado no país teve fisionomia brasileira, porquanto surgiu em meio às condições econômicas, sociais e culturais que lhe eram próprias. Além dos "entraves impostos por uma estrutura social largamente anacrônica" ${ }^{\prime 18}$, havia outra peculiaridade levada em consideração, a saber, as influências africanas e ameríndias que, juntamente com a cultura ocidental, conferiam originalidade ao horizonte cultural brasileiro ${ }^{19}$.

Para Mario Schenberg, o Novo Realismo surgiu como consequência de uma ampliação do horizonte vivencial do ser humano, que contava, entre outras coisas, com o desenvolvimento tecnológico e científico. A psicanálise de Freud também auxiliou nessa ampliação, uma vez que o surgimento da noção de inconsciente motivou uma reavaliação do homem enquanto ser racional. Essa nova realidade demandava um novo senso de humanismo, que fosse capaz dar conta dessa reavaliação. O teor do Novo Humanismo foi entendido como uma valorização do ser humano que ia além do significado que o termo possuía desde o Iluminismo europeu do século XVIII.

Em sentido amplo, qualquer filosofia que tenha em vista a dignidade humana e se posicione com otimismo em relação à sua capacidade de entendimento pode ser caracterizada como humanista. Mas o Humanismo Clássico, como ficou conhecido, surgiu no período

\footnotetext{
${ }^{16}$ Cf. POINCARÈ, Henri. Valor da ciência (Rio de Janeiro: Contraponto, 1995), POINCARÉ, Henri. Science et méthode (Paris: Flammarion, 1947), EINSTEIN, Albert. Como vejo o mundo (Rio de Janeiro: Editora Nova Fronteira, 1981). Com relação à intuição, Schenberg tinha como referência, ainda, o filósofo Henri Bergson, que fez uma crítica a vários aspectos da filosofia ocidental e refletiu acerca da intuição (cf. BERGSON, Henri. Ensaio sobre os Dados Imediatos da consciência Lisboa, Edições 70).

${ }^{17}$ SCHENBERG, Mario. Um Novo Realismo, in Pensando a arte, p. 195.

${ }^{18}$ SCHENBERG, Mario. Pensando a arte, 1988, p. 186.

${ }^{19}$ SCHENBERG, Mario. Pensando a arte, 1988, p.186.
} 
renascentista e propunha uma reaproximação da Antiguidade greco-romana e a celebração dos prazeres da vida, invertendo os valores em vigor na Idade Média. Esses valores reverberaram, posteriormente, no Iluminismo europeu, que se consolidou no século XVIII, pautado por uma visão materialista dos seres humanos, pelo otimismo em relação a seu progresso por meio da educação e por uma concepção, via de regra, utilitarista em relação à sociedade e à ética. A razão humana e sua capacidade de aprendizado por meio da experiência empírica eram faculdades bastante valorizadas dentro desse contexto ${ }^{20}$.

José Luiz Goldfarb apontou que Mario Schenberg, quando fazia referência ao racionalismo iluminista, estava se referindo a um modo de pensamento a partir do século XVIII na Europa, que pode ser aproximado, de certo modo, ao positivismo, que tinha na esfera lógico-matemática o ponto alto da inteligência humana ${ }^{21}$. Em sua dimensão social, acreditava-se que o progresso da ciência seria capaz de solucionar os problemas do homem, sendo que essa visão de mundo fundamentava-se numa concepção da ciência como pautada pela lógica e passível de controle ${ }^{22}$. Para o autor, contudo, o "pensamento de MS [Mario Schenberg] é, em si mesmo, um convite a superar essa concepção, ainda determinante em nossa sociedade" 23 .

$\mathrm{Na}$ visão do Professor Schenberg, o positivismo era problemático, pois minava a imaginação que era, para o crítico, "exatamente a maior qualidade criativa do homem em qualquer campo do pensamento e da ação" $" 24$.

O Novo Humanismo, por seu lado, ia além da primazia da razão. Isso porque, valorizando não apenas a racionalidade, mas também a intuição e a imaginação criadora como faculdades epistemológicas do ser humano, Mario Schenberg propôs uma revalorização de seu estatuto, tendo em vista o descrédito do ser humano na civilização ocidental de então. A busca de um Novo Humanismo levava em conta não apenas o homem enquanto ser racional, mas também em sua dimensão existencial, intuitiva e cósmica.

Considerado pelo crítico como a expressão artística do Novo Humanismo, o Novo Realismo foi definido a partir de um horizonte paralelo: fruto da sociedade industrial e reflexo da cultura ocidental em crise, essa tendência refletiu um momento de ampliação de referenciais:

${ }^{20}$ BLACKBURN, Simon. (Ed.). Dicionário Oxford de Filosofia. Rio de Janeiro: Jorge Zahar Editor, 1997, pp. 187 e 196. MORA, José Ferrater. Dicionario de Filosofía. Buenos Aires: Editorial Sudamericana, 1951, p. 448.

${ }^{21}$ GOLDFARB, José Luiz. Voar também é com os Homens. São Paulo: EDUSP, 1994, pp. 85-6.

${ }^{22}$ GOLDFARB, José Luiz. Voar também é com os Homens. São Paulo: EDUSP, 1994, pp. 85-6.

${ }^{23}$ GOLDFARB, José Luiz. Voar também é com os Homens. São Paulo: EDUSP, 1994, pp. 86.

24 SCHENBERG, Mario. Entrevista com Mário Schenberg. (Publicado originalmente na Revista Trans/Form/Ação, v. 3, p. 6-62, 1980). In Trans/Form/Ação. Marília, v.34, 2011. Edição Especial, p. 144. 
O realismo renascentista, que se prolongou até a Primeira Guerra Mundial, correspondia ao humanismo individualista e burguês, predominante durante aquele período. Foi o humanismo da elite plutocrática. O humanismo atual é eminentemente democrático e social. Sua expressão artística no Novo Realismo está profundamente influenciada pelos meios de comunicação de massa [...], a preocupação com o requinte artesanal é inexistente. [...] há preferência pelo emprego, utilização de imagens habituais, até estereotipadas, e por objetos de emprego corrente ${ }^{25}$.

A partir dessa nova ênfase, o Novo Realismo ia além da valorização do aspecto formal, do requinte artesanal e da valorização do material nobre, levando em consideração o repertório de imagens e símbolos do cotidiano que cercavam a realidade da sociedade ocidental, refletindo o caráter antiaristocrático do Novo Realismo ${ }^{26}$.

No entender de Mario Schenberg, o sentido desse Novo Realismo estaria para o realismo renascentista, assim como o humanismo iluminista estaria para o sentido do Novo Humanismo. Ambos foram caracterizados, entre outras coisas, pela ampliação do significado do real e do humano: enquanto o Novo Humanismo levava em conta não só as esferas do racional, do individual e do social, mas também do existencial e do cósmico; o Novo Realismo iria além da valorização do aspecto formal, do requinte artesanal e da valorização do material nobre, levando em consideração o repertório de imagens e símbolos do cotidiano que cercavam a realidade da sociedade ocidental.

Segundo José Luiz Goldfarb ${ }^{27}$, Schenberg apontou o que talvez tenha sido o maior erro do humanismo clássico: valorizar o homem apenas na dimensão sentimental, mas não logicamente. Isto é, não compreender todas as potencialidades humanas, que poderiam abrir infinitos caminhos. Em suma, o Novo Humanismo de Mario Schenberg privilegiava um homem mais completo e aberto, com suas capacidades mentais desenvolvidas (não somente a razão, mas também a intuição e a imaginação criadora), e que superasse o homem-máquina (baseado numa concepção de racionalismo estrito e instrumental).

Pode-se argumentar que para Mario Schenberg, o Ocidente enfrentava uma crise de valores da sociedade ocidental industrializada, na qual o homem se encontrava desvalorizado em relação à tecnologia e à lógica do capitalismo. Conforme apontou o crítico no texto Caminhos da Arte Atual,

[a] cultura ocidental até agora não se adaptou a situação nova, decorrente do aparecimento da indústria moderna, como já observaram muitos autores. Os seus

\footnotetext{
${ }^{25}$ SCHENBERG, Mario. Pensando a Arte. São Paulo Nova Stella, 1988, p. 186.

${ }^{26}$ SCHENBERG, Mario. Pensando a Arte. São Paulo Nova Stella, 1988, p. 186

${ }^{27}$ GOLDFARB, José Luiz. Voar também é com os Homens. São Paulo: EDUSP, 1994, p. 168.
} 
fundamentos datam ainda de antes do século XVIII, quando teve início a primeira Revolução Industrial. A grande crise cultural se manifesta no momento em que se inicia a segunda Revolução Industrial, caracterizada pelo desenvolvimento da tecnologia eletrônica e cibernética e da tecnologia atômica ${ }^{28}$.

Enquanto a tecnologia da primeira Revolução Industrial permitiu a substituição de parte do trabalho físico do homem, na Segunda Revolução Industrial, a tecnologia cibernética permitiu substituir o pensamento, isto é, o trabalho mental humano ${ }^{29}$. Mario Schenberg mencionou, como exemplo, o "cérebro eletrônico", como ficou popularmente conhecido o computador eletrônico. Em sua perspectiva, era inevitável que a introdução de "máquinas pensantes" afetasse "fundamentalmente toda a cultura moderna"30.

Além disso, havia a tecnologia atômica. Embora não estivesse presente na indústria até aquele momento, ela tinha influência no horizonte da civilização ocidental desde as bombas atômicas, em 1945. Desde então, a humanidade vivia sob o perigo de extermínio em massa ou mesmo total. $\mathrm{O}$ crítico considerava que essa situação trouxe efeitos políticos, morais e psicológicos profundos, sentidos principalmente pelas gerações mais jovens, da qual decorria o descrédito dos princípios éticos dessa civilização ${ }^{31}$.

Foi notável, nos anos de 1940, a posição de Albert Einstein (que Mario Schenberg conheceu na Princeton University-EUA), que havia se colocado publicamente a favor de uma revalorização do ser humano em sua dignidade, manifestando-se contra a corrida armamentista e incentivando o pacifismo ${ }^{32}$. Desde o fim da Segunda Guerra Mundial, em 1945, a tensão entre Estados Unidos e União Soviética fazia parte da ambientação desse momento histórico, polarizando as relações internacionais.

Para Schenberg, a civilização ocidental, fundada na primazia da razão, que vinha sendo cada vez mais valorizada desde o século XVIII, enfatizava uma racionalidade que se pode definir como instrumental. Foi esse o tipo de pensamento que a segunda Revolução Industrial tornava possível substituir: uma racionalidade tecnológica. Essa instância da racionalidade, que trabalha por meio do cálculo de possibilidades, pesando os meios em vista dos fins, não representava, para Mario Schenberg, toda a potencial dimensão da racionalidade humana.

\footnotetext{
${ }^{28}$ SCHENBERG, Mario. Caminhos da Arte Atual. In Pensando a Arte. São Paulo Nova Stella, 1988, p. 203. O artigo foi publicado originalmente com o título de Caminhos da Arte de Hoje, no Jornal do Brasil, em 27 de setembro de 1969.

${ }^{29}$ SCHENBERG, Mario. Caminhos da Arte Atual. In Pensando a Arte. São Paulo Nova Stella, 1988, p. 203.

${ }^{30}$ SCHENBERG, Mario. Caminhos da Arte Atual. In Pensando a Arte. São Paulo Nova Stella, 1988, p. 203.

${ }^{31}$ SCHENBERG, Mario. Caminhos da Arte Atual. In Pensando a Arte. São Paulo Nova Stella, 1988, p. 204.

${ }^{32}$ EINSTEIN, Albert. Como vejo o mundo. Rio de Janeiro: Editora Nova Fronteira, 1981.
} 
A exacerbação dessa visão tecnológica teria resultado numa sociedade que não valorizava o homem de fato, embora o fizesse sentimentalmente. Afinal, a tecnologia

\begin{abstract}
não decide as questões fundamentais. Eu acho que isso é muito lógico. O grande erro do Ocidente consiste em não vê-lo. É porque o Ocidente não acredita no Homem, o Ocidente acredita muito na máquina e pouco no Homem, não é? [...] Isso é típico da mentalidade ocidental de hoje. Mas todo o Ocidente faz uma subestimação muito grande do homem, e se vê o homem tem capacidades que talvez nem tenham sido ainda bastante compreendidas [...]. Então eu acho que o Ocidente subestima o homem, e superestima a tecnologia ${ }^{33}$.
\end{abstract}

Diante desse contexto, o crítico constatou que a forma de humanismo vigente não era mais capaz de dar conta do ser humano, nem das novas demandas daquele momento histórico. Se, por um lado, a concepção da racionalidade se estreitava cada vez mais; por outro, a psicanálise e o contato com civilizações não ocidentais abriam novos horizontes a uma sociedade que se encontrava em crise.

Um Novo Humanismo se fazia necessário, a fim de contemplar faculdades do ser humano até então desvalorizadas em relação à razão, bem como outras relativamente recémdescobertas, como o inconsciente. Era preciso alertar a sociedade para o fato de que "acima da tecnologia e das máquinas" era preciso que estivesse "o homem com sua incrível capacidade criativa e intuitiva" 34 .

A partir disso, foi possível retomar a analogia feita pelo crítico para definir o Novo Realismo: assim como o que chamou de humanismo iluminista havia se tornado insuficiente para conter as novas fronteiras da cosmovisão da civilização ocidental do século XX; também a sua necessidade de expressão artística já não cabia mais no realismo de fundo renascentista. Enquanto o Novo Humanismo ia em direção às demandas individuais, sociais, vivenciais e cósmicas de um ser humano não visto apenas como ser racional, mas também, ao mesmo tempo, como ser intuitivo e criativo; o Novo Realismo contemplaria os diversos aspectos dessa visão de mundo ampliada, indo ao encontro das novas motivações cujos desdobramentos se tornaram presentes na arte.

No texto Arte e Tecnologia ${ }^{35}$, escrito já na década de 1970, o crítico desenvolveu um aprofundamento de alguns aspectos dessa comparação. Enquanto na arte tradicional, as obras eram produzidas com base na maestria artesanal do métier, de modo que a capacidade do

33 SCHENBERG, Mario. Entrevista com Mário Schenberg. (Publicado originalmente na Revista Trans/Form/Ação, v. 3, p. 6-62, 1980). In Trans/Form/Ação. Marília, v.34, 2011. Edição Especial, p 128.

${ }^{34}$ GOLDFARB, José Luiz. Voar também é com os Homens. São Paulo: EDUSP, 1994, p. 164.

${ }^{35}$ SCHENBERG, Mario. Arte e Tecnologia. In GULLAR, Ferreira \& PEDROSA, Mário. Arte brasileira hoje: situação e perspectivas. Rio de Janeiro: Paz e Terra, 1973. 
artista era avaliada por sua habilidade técnica; na arte contemporânea, a dimensão da técnica não era mais o centro da criação artística: “[h]oje, a habilidade artística aparece claramente separada de qualquer habilidade técnica, quando o escultor pode 'fazer' esculturas por telefone, transmitindo as instruções para a fábrica onde serão executadas" ${ }^{\text {"36. }}$.

Outros procedimentos, como a assemblage, que retira objetos pré-existentes de seu contexto, transformando-os em obras de arte, ou o uso de computadores também exemplificavam a perspectiva de que a criação de uma obra passou a depender da elaboração de um projeto, e não mais - apenas - do domínio das técnicas tradicionais por parte do artista.

Se, tradicionalmente, as obras de arte eram objetos valiosos, duradouros; o Novo Realismo envolvia a noção do efêmero, do transitório e da produção em série. Para Mario Schenberg, a utilização de materiais efêmeros era uma das características mais interessantes da arte de vanguarda. Foi colocado como exemplo disso o trabalho de artistas como Lygia Clark, Hélio Oiticica e Mira Schendel, entre outros, que perfaziam uma admirável "poética objetal do efêmero, que transmite uma impressão pungente da dissolução das coisas no fluxo do tempo e das novas vivências espaciais" 37 .

Por fim, se o espaço renascentista era estático, rígido e feito para ser contemplado à distância, isto é, do lado de fora da obra, o espaço da arte do século XX havia rompido com essa estrutura, o que se deu por meio da arte abstrata, da construtiva e da antiarte dadaísta. Para o crítico, a primeira criou espaços não representativos, operando uma libertação da representação naturalista; as duas últimas introduziram o movimento mecânico e efeitos luminosos nas obras, bem como o acaso (por exemplo: a escrita automática e o novo olhar para os objetos cotidianos), contrapondo-se à noção de solenidade e grandiosidade da arte tradicional. Mario Schenberg ressaltou, ainda, a importância da arte concreta, que influenciou o desenvolvimento da op art e da arte cinética após a segunda guerra mundial. O concretismo teve grande influência entre os artistas da América Latina, que dariam importantes contribuições à arte cinética e à arte ambiental.

Essa era, para Schenberg, a nova realidade da arte, deflagrada a partir da década de 1960, momento em que o crítico começou a elaborar seu Novo Realismo. O material nobre, o apego à técnica e à forma já não eram princípios que regiam o universo artístico de então. Por isso, a arte se tornava democrática, na medida em que saía do suporte tradicional e ganhava o espaço do espectador (que passava a participador, nas palavras de Hélio Oiticica) para ser

\footnotetext{
${ }^{36}$ SCHENBERG, Mario. Arte e Tecnologia. In GULLAR, Ferreira \& PEDROSA, Mário. Arte brasileira hoje: situação e perspectivas. Rio de Janeiro: Paz e Terra, 1973, p. 86.

${ }^{37}$ SCHENBERG, Mario. Arte e Tecnologia. In GULLAR, Ferreira \& PEDROSA, Mário. Arte brasileira hoje: situação e perspectivas. Rio de Janeiro: Paz e Terra, 1973, p. 89.
} 
vivenciada do lado de dentro, como a arte sensorial de Lygia Clark, por exemplo. Foi nesse sentido que o Novo Realismo despontou, para o crítico, como "a efetiva síntese dialética das principais correntes das artes do século XX, que assimila todas as conquistas anteriores"38.

Diante dessas considerações, foi possível retomar a afirmação do artista Hélio Oiticica, segundo a qual a visão do Novo Realismo que orientou o surgimento da Nova Objetividade Brasileira foi a de Mario Schenberg, e não a de Pierre Restany ${ }^{39}$. Não coube a este estudo realizar uma análise comparativa exaustiva das visões desses dois críticos de arte. Mesmo assim, foi realizada uma breve análise do Nouveau Réalisme de Pierre Restany.

Em 27 de outubro de 1960, na residência parisiense de Yves Klein, foi fundado o grupo dos Nouveaux Réalistes, cuja declaração se limitava a uma ata reconhecendo a especificidade da proposta coletiva de seus membros: "Os novos realistas se conscientizaram de sua singularidade coletiva. Novo Realismo = novas abordagens perceptivas do real. Assinado: Arman, Dufrêne, Hains, Klein, Raysse, Restany, Spoerri, Tinguely e Villeglé”40. César e Rotella foram convidados, mas não puderam estar presentes. Posteriormente, uniramse a eles Niki de Saint-Phalle (no ano seguinte), Christo e Deschamps, em 1962.

Esse "novo aproximar-se do real" constituía uma ideia geral, que cada um dos artistas trabalhava de acordo com motivações específicas, o que pôde ser visto pela enumeração, feita por Restany ${ }^{41}$, dos três eixos do Novo Realismo:

1) Um método de percepção e comunicação sensível a serviço de uma intuição cósmica (pesquisas de Yves Klein);

2) Uma vontade de integrar a técnica industrial na metamorfose do cotidiano (a apropriação do universo mecânico por Jean Tinguely);

3) Uma preocupação de recuperar poeticamente as formas mais correntes de explosão das linguagens visuais organizadas: manifestos, publicidade, mass media (coleta de manifestos rasgados feita por Raymond Hains).

O elo unificador de poéticas aparentemente tão distintas era a noção de apropriação do real, que aparecia como ideia central do Nouveau Réalisme de Restany ${ }^{42}$. O crítico utilizava o termo "realidade sociológica" para designar a realidade circundante na qual estavam inseridos os artistas enquanto seres humanos. Como consequência, o próprio real se tornava linguagem

${ }^{38}$ SCHENBERG, Mario. Propostas 65. In Pensando a Arte. São Paulo: Nova Stella, 1988, p. 179.

${ }^{39}$ OITICICA, Hélio. Situação da Vanguarda no Brasil (Propostas 66). In FERREIRA, Glória (org.). Crítica de arte no Brasil: temáticas contemporâneas. Rio de Janeiro: Funarte, 2006. O texto foi publicado em 1966, na revista Artes: (São Paulo, 1966. Ano I, n. ${ }^{\circ}$ 9, nov.-dez, 1966).

${ }^{40}$ ITAUU CULTURAL. Enciclopédia de Artes Visuais Itaú Cultural. Disponível em: www.itaucultural.org.br Acesso em 02/10/2012.

${ }^{41}$ RESTANY, Pierre. Os Novos Realistas. São Paulo: Perspectiva, 1979.

${ }^{42}$ RESTANY, Pierre. Os Novos Realistas. São Paulo: Perspectiva, 1979, p. 31. 
e criava suas poéticas, na medida em que fragmentos dele eram apropriados pelos artistas e apresentados como arte. Nessa medida, a arte estava no real; o real era arte.

Por "realidade sociológica", Restany ${ }^{43}$ entendia a "escala natural dessa atitude apresentadora: o lugar-comum, o elemento de refugo e o objeto de série são arrancados ao nada da contingência ou ao reino do inerte; o artista tornou-os seus, e, ao assumir essa responsabilidade possessiva, confere-lhes plena vocação significante."

Esse novo olhar, voltado para o maravilhoso da natureza moderna, foi a solução encontrada para a crise das linguagens tradicionais da arte (pintura, escultura, etc), de um lado e, de outro, para o impasse a que chegara a abstração (lírica, formal, expressionismo abstrato). Segundo o crítico, as linguagens tradicionais da arte não ofereciam mais atrativos que prendessem o olhar e a atenção do público, em vista da infinidade de imagens e da publicidade às quais a visão da década de 1960 já havia se acostumado. A abstração, por sua vez, não encontrava mais campo para reinventar-se e, estagnada, resumia-se a uma sucessão de seguidores dos artistas que haviam, de fato, dado contribuições válidas à abstração ${ }^{44}$.

Se o abstracionismo abolia a natureza e a figuração de seu programa, o Nouveau Réalisme voltava a colocar os pés no chão para inserir-se na realidade cotidiana, buscando no banal o maravilhoso contemporâneo. Essa aproximação do real, contudo, não mais se daria pela formulação conceitual ou pela representação, mas pela apropriação de seus fragmentos ${ }^{45}$.

Em lugar de representar, os novos realistas apresentavam, nos objetos dos quais se apropriavam, o convite para a apreensão da realidade - moderna, tecnológica e industrial - de maneira direta, ou seja, sem mediação conceitual. O ready-made de Marcel Duchamp embasou o procedimento da apropriação, mas sua negatividade original foi deixada de lado: o objeto era, então, a afirmação da consciência da realidade sociológica e de sua dimensão poética. Para Restany era nesse sentido que os novos realistas eram "mentes disponíveis que têm sempre um novo olhar para o mundo" ${ }^{, 46}$.

O crítico observou, ainda, que o Nouveau Réalisme tinha como fé fundamental a objetividade da consignação: “O realismo não discute nem o contexto nem o cenário de sua vida: identifica-se com o real, nele se insere, se integra. As intenções, ou segundas intenções, os engajamentos ou as reservas vêm em seguida" ${ }^{47}$.

\footnotetext{
${ }^{43}$ RESTANY, Pierre. Os Novos Realistas. São Paulo: Perspectiva, 1979, p,152.

${ }^{44}$ RESTANY, Pierre. Os Novos Realistas. São Paulo: Perspectiva, 1979, p. 118.

${ }^{45}$ RESTANY, Pierre. Os Novos Realistas. São Paulo: Perspectiva, 1979.

${ }^{46}$ RESTANY, Pierre. Os Novos Realistas. São Paulo: Perspectiva, 1979, p. 39.

${ }^{47}$ RESTANY, Pierre. Os Novos Realistas. São Paulo: Perspectiva, 1979, p. 140.
} 
Enquanto parte da realidade sociológica na qual o artista estava inserido, acontecimentos políticos poderiam permear a arte (Raymond Hains, por exemplo, realizou descolagens de cartazes com temas políticos no início da década de 1960). Mas Restany não indicava o posicionamento social e político de maneira explícita em sua formulação do Nouveau Réalisme, nem discorreu sobre a necessidade de engajamento, seja quando da fundação do grupo dos Nouveaux Réalistes, seja em reflexões posteriores a respeito do Novo Realismo enquanto tendência geral da arte.

Foi possível observar que Mario Schenberg e Pierre Restany refletiram acerca do Novo Realismo enfatizando elementos diferentes, apesar dos pontos de confluência. Levandose em conta que, para ambos, essa tendência se caracterizava justamente por caminhar rente à realidade das coisas, não poderia ser de outra forma. Nenhum dos críticos, ao refletir sobre o Novo Realismo, coloca diretamente a necessidade de engajamento político como participação do artista na militância política.

Contudo, que o crítico francês deixou claro, de sua parte, que o novo realismo por ele concebido não discute o contexto da vida, mas integra-se nela, mantendo sua fé fundamental: a consignação do objeto. Outras motivações, engajamentos ou reservas, se presentes, viriam em seguida ${ }^{48}$. Ou seja, a preocupação política e a crítica social poderiam aparecer, mas de modo indireto.

Apesar de sua atuação política como militante do Partido Comunista, Schenberg se distanciou de sua orientação artística, a saber, o Realismo Socialista Soviético. Em lugar disso, o crítico apoiava as vanguardas emergentes desde a década de 1950 (e também posteriormente), pois considerava que estariam mais abertas às recentes demandas do momento histórico, podendo responder melhor ao desafio da descoberta de seus valores em gestação $^{49}$.

Schenberg via na intuição a capacidade do artista de perceber aspectos muito sutis de seu trabalho, tudo o que dizia respeito a como este desenvolvia e trabalhava a linguagem por meio da qual vertia sua visão de mundo nas obras que produzia. Mais ainda, intuição envolvia a percepção de tendências (artísticas, humanas e históricas), e o modo como o artista decidia responder à sua própria existência por meio da arte e das questões humanas levantadas por meio dela. Nesse sentido, o fazer artístico podia não envolver a militância política, mas com

\footnotetext{
${ }^{48}$ RESTANY, Pierre. Os Novos Realistas. São Paulo: Perspectiva, 1979.

${ }^{49}$ Cf. SHCNBERG, Mário. O espaço social do Artista. Arquivo Centro Mário Schenberg de Documentação e Pesquisa em Artes. Texto sem não numerado e não datado. Cabe dizer ainda que a intuição, para o crítico de arte, não era privilégio de alguns eleitos, mas uma faculdade que todos os seres humanos possuíam, podendo desenvolvê-la em maior ou menor medida. Sobre isso, cf. Alecsandra Matias de Oliveira. Schenberg: crítica e criação. São Paulo Edusp, 2011.
} 
certeza requeria do artista uma reflexão sobre os aspectos de sua realidade e um posicionamento a respeito dela.

Para Schenberg, era importante se posicionar em relação à realidade social e política, pois isso poderia incentivar outras pessoas a fazerem o mesmo. O crítico procurava dar esse exemplo: “[e]u sempre fui um homem de posições políticas definidas. Sempre que tenho certeza, alguma certeza, tomo posições políticas definidas. É um dever que a gente tem. Mesmo que a gente erre. Assim acho que ajudamos mais as pessoas ${ }^{50}$.

Por isso, Mario Schenberg viu com bons olhos o surgimento da consciência política na década de 1960, aspecto desencadeado pela instauração do regime militar no país, conforme já foi apontado. O crítico incentivava a participação política e a tomada de posição dos artistas com relação aos acontecimentos. Assim como faria nos anos de 1980, sugerindo que Gilberto Gil compusesse uma canção sobre o Apartheid na África do $\mathrm{Sul}^{51}$, o crítico também levantou a questão da politização em sua interação com os artistas da vanguarda brasileira.

A necessidade de tomada de posição política se impunha à realidade artística dos anos de 1960, e Mario Schenberg, inserido profundamente nessa realidade, soube contemplar esse aspecto em sua visão do Novo Realismo. Ainda que a preocupação com a dimensão política da arte não apareça explicitamente como item de um programa a ser seguido na formulação feita por Schenberg acerca do Novo Realismo, para o crítico, pensar a realidade e estar aberto a seus valores em gestação significava, naquele momento histórico, refletir sobre política e posicionar-se em relação aos acontecimentos sociais, culturais e políticos.

No texto Esquema Geral da Nova Objetividade, de 1967, Hélio Oiticica ${ }^{52}$ apontou Mario Schenberg como um dos quatro críticos que influenciaram o desenvolvimento da Nova Objetividade com seu pensamento, obra e atuação (os outros foram Ferreira Gullar, Frederico Morais e Mário Pedrosa). Ao concluir o escrito, o artista afirmou que

Mário Schenberg, numa de nossas reuniões, indicou um fato importantíssimo para
nossa posição como grupo atuante: hoje, o que quer que se faça, qualquer que seja a
nossa démarche, se formos um grupo atuante, realmente participante, seremos um
grupo contra coisas, argumentos, fatos. [...] No Brasil (nisto também se
assemelharia ao Dadá) hoje, para se ter uma posição cultural atuante, que conte,

${ }^{50}$ In HAMBURGUER, Amélia Império. Nota biográfica e entrevista com Mario Schenberg (Novembro, 1983). São Paulo: Instituto de Física, Universidade de São Paulo, 1984, p. 28. Foi mantida a grafia original.

${ }^{51}$ CEDRAN, Lourdes (Coord.). Diálogos com Mário Schenberg. São Paulo: Nova Stella, 1985.

${ }^{52}$ OITICICA, Hélio. Esquema Geral da Nova Objetividade. In FERREIRA, Glória; COTRIM, Cecília (seleção e comentários). Escritos de artistas: anos 60/70. Tradução de Pedro Süssekind. et al. - 2. Ed. - Rio de Janeiro: Jorge Zahar Ed., 2009. 


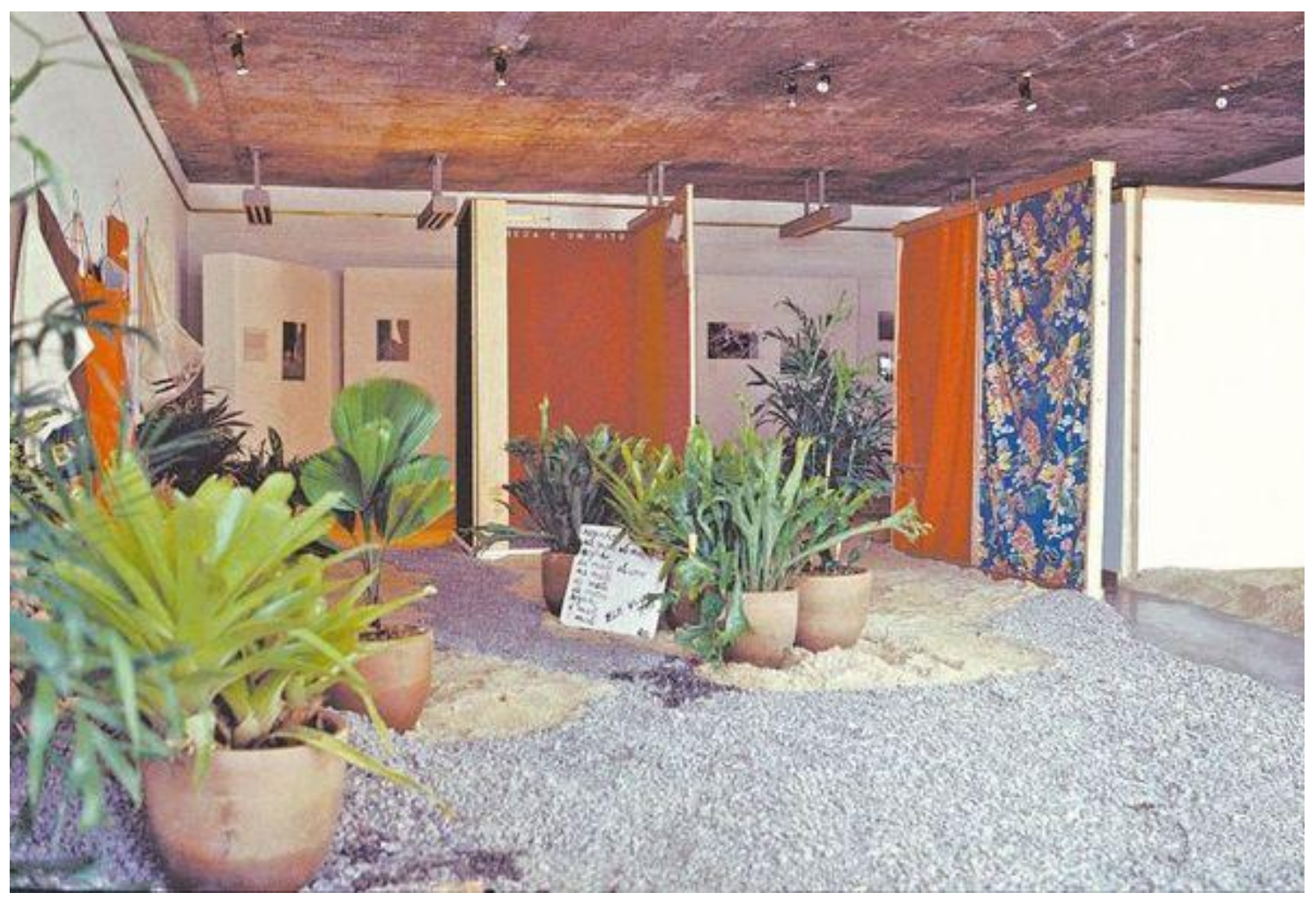

Figura 1 - Hélio Oiticica, Tropicália , 1967. Plantas, areia, pedras, araras, aparelho de televisão, tecido e madeira. Projeto Hélio Oiticica (Rio de Janeiro, RJ). Vista parcial da instalação Tropicália - PB2 (Imagético) e PN3 (A Pureza é um Mito) - mostra Nova Objetividade Brasileira, realizada no MAM-RJ, em 1967. Reprodução fotográfica César Oiticica Filho.

tem-se que ser contra, visceralmente contra tudo que seria em suma o conformismo cultural, político, ético, social ${ }^{53}$.

Oiticica deixou claro, ainda, que o conceito de realismo de Schenberg foi significativo para a formulação das características da arte de vanguarda proposta pelos artistas da Nova Objetividade Brasileira, na medida em que apontou para uma nova compreensão da realidade, bem como pelo fato de ter valorizado uma "forma de arte participante", em outras palavras, uma arte que participava da realidade ${ }^{54}$. Além disso, o destaque dado à contribuição de Schenberg permitiu aquilatar sua influência entre artistas e teóricos desse contexto.

Apesar de preferir o termo Nova Objetividade em lugar de Novo Realismo, Oiticica deixou claro, em vários momentos do texto, que a concepção que Mario Schenberg

${ }^{53}$ OITICICA, Hélio. Esquema Geral da Nova Objetividade. In FERREIRA, Glória; COTRIM, Cecília (seleção e comentários). Escritos de artistas: anos 60/70. Tradução de Pedro Süssekind. et al. - 2. Ed. - Rio de Janeiro: Jorge Zahar Ed., 2009, p. 167.

${ }^{54}$ SCHENBERG, Mario. Pensando a Arte. São Paulo: Nova Stella, 1988. A expressão arte participante, aqui, não faz referência à arte de participação, mas à arte que visa participar da realidade, com ela interagindo. A segunda, surgida ainda com o movimento Neoconcreto e levada adiante pela Nova Objetividade Brasileira, teve sua origem no questionamento da pura contemplação da obra de arte, bem como do estatuto do quadro e da escultura. A arte de participação foi caracterizada pelo estímulo à participação do espectador por meios cada vez mais sofisticados ao longo de seu desenvolvimento e não tinha em vista diretamente a participação política. 
desenvolveu dessa tendência foi relevante em diversos aspectos apontados pelo artista. Entre eles, a "abordagem e tomada de posição em relação a problemas políticos, sociais e éticos" O artista via no termo "novo realismo" de Schenberg uma analogia com o realismo histórico como de fato era - e optou pela designação Nova Objetividade justamente para marcar o distanciamento da posição do grupo, na medida em que este desejava romper completamente com a história da arte em sua concepção tradicional ${ }^{56}$.

Roberto Schwartz ${ }^{57}$ observou que no período entre a instauração do Regime Militar e a decretação do Ato Institucional $n^{\circ}$. 5, em 1968, a hegemonia cultural e intelectual da esquerda convivia com o regime de direita, embora não se possa definir essa convivência como pacífica. O recrudescimento desse estado de coisas teve no AI-5 um instrumento de perseguição a intelectuais e militantes políticos considerados como ameaça pelo regime (entre eles Mario Schenberg). Em nível internacional, a ameaça da guerra nuclear e da extinção da humanidade que perpassavam a ambientação da Guerra Fria também eram elementos significativos desse contexto.

Agir politicamente e buscar engajamento, nesse contexto, não significavam necessariamente abraçar a militância de causas partidárias, mas tomar posição, indo contra conformismos, fossem eles culturais, sociais ou políticos. Assim, o viés político da arte estaria em fazer com que o público tomasse consciência de sua realidade, buscando nisso seu potencial modificador do homem e da realidade na qual estava inserida, "menos pela mensagem explícita, do que pela vivência social, coletiva, que propiciava, que a arte possuía impacto político" ${ }^{, 58}$.

Sobre isso, Mario Schenberg ${ }^{59}$ fez uma observação precisa na década de 1980, mas que, conforme se pôde supor, já refletia seu pensamento quando da formulação de seu Novo Realismo:

$\mathrm{O}$ artista às vezes registra, por sua sensibilidade, pela intuição, uma série de coisas de caráter político, se bem que ele mesmo possa não estar inclinado a tomar atitudes

\footnotetext{
${ }^{55}$ OITICICA, Hélio. Esquema Geral da Nova Objetividade. In FERREIRA, Glória; COTRIM, Cecília (seleção e comentários). Escritos de artistas: anos 60/70. Tradução de Pedro Süssekind. et al. - 2. Ed. - Rio de Janeiro: Jorge Zahar Ed., 2009, p. 154.

56 ARANTES, Otília Beatriz Fiori. Depois das Vanguardas, in Arte em Revista, São Paulo, 5 (7), 1983, pp. 520.

${ }^{57}$ SCHWARZ, Roberto. Cultura e Política, 1964-69, in O Pai de Família e outros estudos. Rio de Janeiro: Paz e Terra, 1978.

58 ARANTES, Otília Beatriz Fiori De Opinião-65 a XVIII Bienal. In: Novos Estudos. (15), São Paulo, CEBRAP, jul.1986, p.1.

59 SCHENBERG, Mario. Entrevista com Mário Schenberg. (Publicado originalmente na Revista Trans/Form/Ação, v. 3, p. 6-62, 1980). In Trans/Form/Ação. Marília, v.34, 2011. Edição Especial, p 160.
} 
que são políticas. A obra dele pode ter uma significação política independentemente de sua atitude.

Nesse sentido, toda obra de arte, bem como qualquer outra obra intelectual, tinha, para o crítico, um significado político, mesmo que o artista que a elaborou não tivesse a intenção consciente e explícita de dar uma conotação política a ela ${ }^{60}$. A partir dessa perspectiva, pôdese notar que, o sentido político da arte iria além da intenção consciente do artista.

\section{Maurício Nogueira Lima}

Maurício Nogueira Lima(Recife/PE 1930 - Campinas/SP 1999) conviveu intensamente com Mario Schenberg, principalmente na década de 1960. Ambos pernambucanos, o crítico e o artista tinham em comum, ainda, a militância política ligada ao partido Comunista ${ }^{61}$. Para o crítico, o arquiteto paulista foi um dos "iniciadores do movimento pop brasileiro ${ }^{62}$.

Aos dois anos de idade, Maurício Nogueira Lima mudou-se para São Paulo com seus pais. No fim da década de 1940, estudou artes plásticas em Porto Alegre, na Universidade Federal do Rio Grande do Sul - UFRGS. Ao retornar a São Paulo, estudou, também, comunicação visual, desenho industrial e propaganda no Instituto de Arte Contemporânea do Museu de Arte de São Paulo - MASP, onde entra em contato com o meio artístico paulistano $^{63}$.

Convidado por Waldemar Cordeiro, a partir de 1953, Maurício Nogueira Lima fez parte do Grupo Ruptura, integrando-se no movimento concreto. No fim dos anos de 1950, o pintor e artista gráfico tornou-se também arquiteto, pela Universidade Presbiteriana Mackenzie em 1958. Maurício Nogueira Lima lecionou em diversas escolas a partir da década de 1970, entre elas a Faculdade de Arquitetura da Universidade de São Paulo ${ }^{64}$.

Não foram encontrados estudos sobre a obra artística de Maurício Nogueira Lima, embora existam vários catálogos publicados por ocasião de exposições (individuais ou

60 SCHENBERG, Mario. Entrevista com Mário Schenberg. (Publicado originalmente na Revista Trans/Form/Ação, v. 3, p. 6-62, 1980). In Trans/Form/Ação. Marília, v.34, 2011. Edição Especial.

${ }^{61}$ LIMA, Maurício Nogueira. Mário Schenberg: incentivador e crítico. In AJZENBERG, Elza (org.). Schenberg - Arte e Ciência. São Paulo, 1995, pp. 40-43.

${ }^{62}$ SCHENBERG, Mario. Pensando a Arte. São Paulo: Nova Stella, 1988, p. 194.

${ }^{63}$ ITAÚ CULTURAL. Enciclopédia de Artes Visuais Itaú Cultural. Disponível em: www.itaucultural.org.br Acesso em 09/07/2013.

${ }^{64}$ ITAÚ CULTURAL. Enciclopédia de Artes Visuais Itaú Cultural. Disponível em: www.itaucultural.org.br Acesso em 09/07/2013. Veja-se, ainda, o Anexo E, para mais dados biográficos. 
coletivas) das quais o artista participou. Mesmo em relação a esse material, poucas considerações foram feitas, até o momento, a respeito de sua produção da década de 1960 , quando o artista trabalhou com elementos da Pop Art.

Vindo da pesquisa formal do Concretismo, o artista explorou, nos anos de 1960, a relação entre Arte e Política utilizando elementos do Novo Realismo e da Pop Art. No texto Cinco Arquitetos Pintores, de 1966, Schenberg apontou que seus primeiros trabalhos nessa direção ainda apresentavam influência do Concretismo, tanto na organização plástica quanto na disposição dos textos escritos nas telas ${ }^{65}$. Para Mario Schenberg, Maurício Nogueira Lima soube unir o profundo conhecimento da expressão plástica proveniente do Concretismo à sua experiência publicitária ${ }^{66}$.

Um exemplo desse momento foi a tela Não entre à esquerda, de 1964. Nela foi possível perceber, na geometricidade da composição das setas orientadas, a influência de sua fase anterior. Contudo, a presença da figuração e de palavras escritas na tela, própria das novas tendências realistas, indicavam uma mudança de direção no trabalho do artista.

Não se pôde deixar de observar a temática política implícita na tela, executada um ano após o Golpe Militar. A indicação "não entre à esquerda", juntamente com as setas que apontam para diversos pontos da cidade de São Paulo (Liberdade, Paraíso e Bela Vista de um lado e, do outro, Consolação, Casa Verde e Carandiru), instala a referência à perseguição e ao perigo de se estar politicamente à esquerda naquele contexto.

O crítico observou o próximo passo do artista que, utilizando a colagem, afastava-se da influência do Concretismo ${ }^{67}$. A obra No ar, No war, de 1966, já apresenta, segundo Schenberg, um colorido mais solto e uma liberdade maior na composição. Novamente, figuram palavras na obra, trazendo para o trabalho a dimensão semântica. Com relação à temática, a mensagem transmitida é bastante clara, posicionando-se em favor do pacifismo, conforme o próprio título indica: No War (do inglês: sem guerra). O texto colocado na parte superior esquerda do trabalho, "peço demissão do mundo" aponta para uma atitude de não concordância em relação à possibilidade de haver uma guerra nuclear, conforme já foi apontado. Verificou-se, ainda, uma disposição das letras dotada de mais liberdade compositiva.

Por fim, Mario Schenberg, observou que Maurício Nogueira Lima foi deixando de lado a colagem, para pintar ele mesmo as imagens, o que teria conferido "maior organicidade

${ }^{65}$ SCHENBERG, Mario. Pensando a Arte. São Paulo: Nova Stella, 1988, p. 188.

${ }^{66}$ SCHENBERG, Mario. Exposição dos sete. Arquivo do Centro Mario Schenberg de Documentação da Pesquisa em Arte - ECA/USP. Texto não datado, p. 1.

${ }^{67}$ SCHENBERG, Mario. Pensando a Arte. São Paulo Nova Stella, 1988, p. 188. 
e simplicidade às composições" ${ }^{\text {68 }}$. Nesses trabalhos, o crítico destaca a adoção de uma narrativa, bem ao sabor das histórias em quadrinhos. "Tchaf" positivo foi colocado como exemplo dessa fase do artista. Duas figuras humanas, uma masculina e outra feminina, dividem espaço com a palavra grafada: "tchaf", onomatopeia que remete ao som de um tapa que teria atingido uma das personagens.

Outra obra que mereceu destaque foi Marilyn Monroe, serigrafia de 1969, cuja temática girou em torno desse ícone do mass media, elemento bastante explorado pela Pop Art. Não se pôde deixar de apontar, ainda, a proximidade desse trabalho com as Mariluns de Andy Warhol, feitas pelo artista norte-americano desde o início dos anos de 1960.

Percebeu-se, nas obras de Maurício Nogueira Lima dos anos de 1960, uma preocupação em evidenciar um posicionamento não apenas político, mas também social. Nos dois primeiros exemplos, as referências de ordem política surgiram mais claramente, evidenciando uma tomada de posição em relação à realidade por meio do jogo de sugestionamento apresentado ao observador.

Talvez, nos dois últimos exemplos, com elementos e temáticas que se distanciavam, pelo menos de modo direto, de um pop político, outras referências tenham ganhado espaço. Embora não se possa afirmar que os ídolos do mass media não tenham uma dimensão política, notou-se uma nova direção nas pesquisas do artista.

${ }^{68}$ SCHENBERG, Mario. Pensando a Arte. São Paulo Nova Stella, 1988, p. 188. 


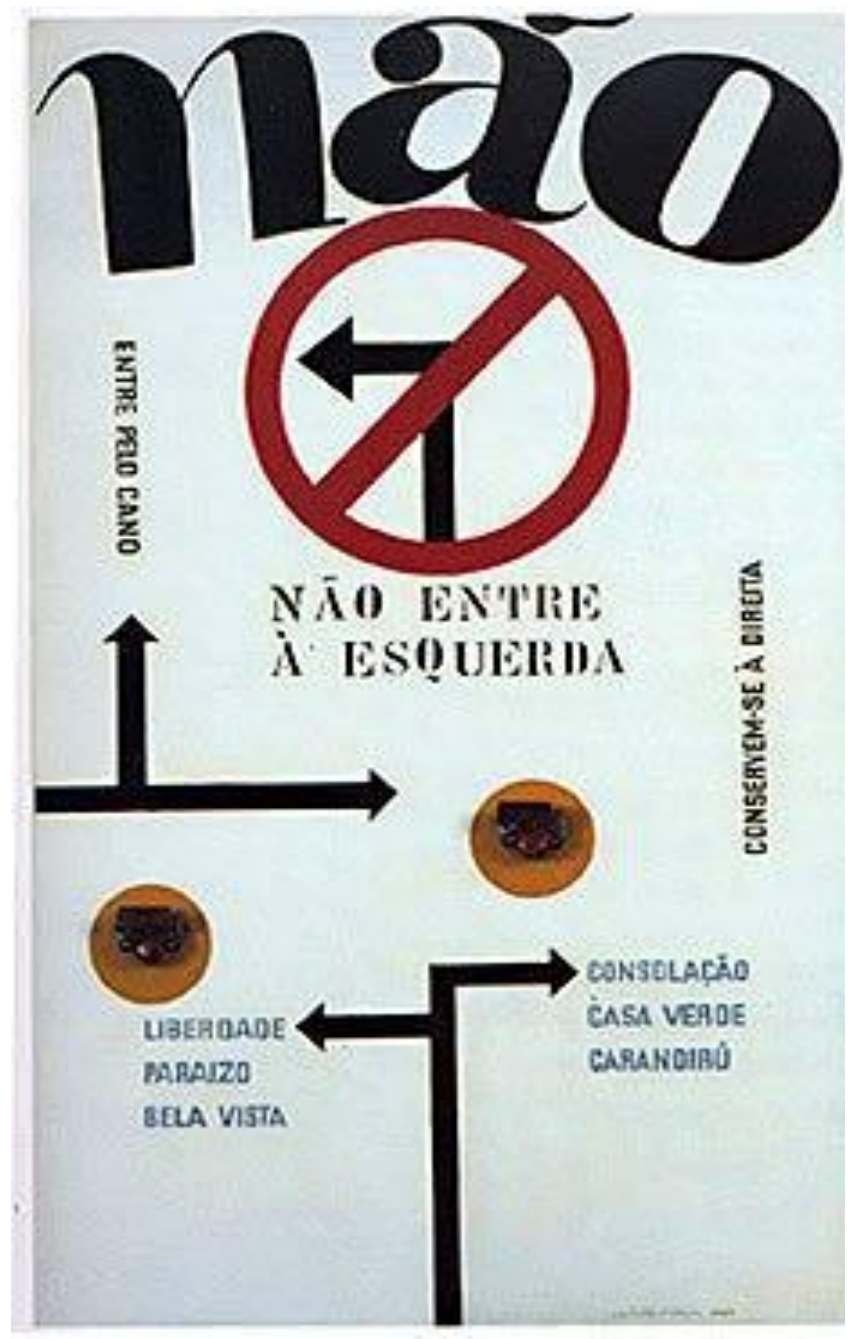

Figura 2 - Maurício Nogueira Lima, Não entre à esquerda, 1964, Metal e esmalte sintético sobre aglomerado, Acervo Museu de Arte Moderna-SP. 


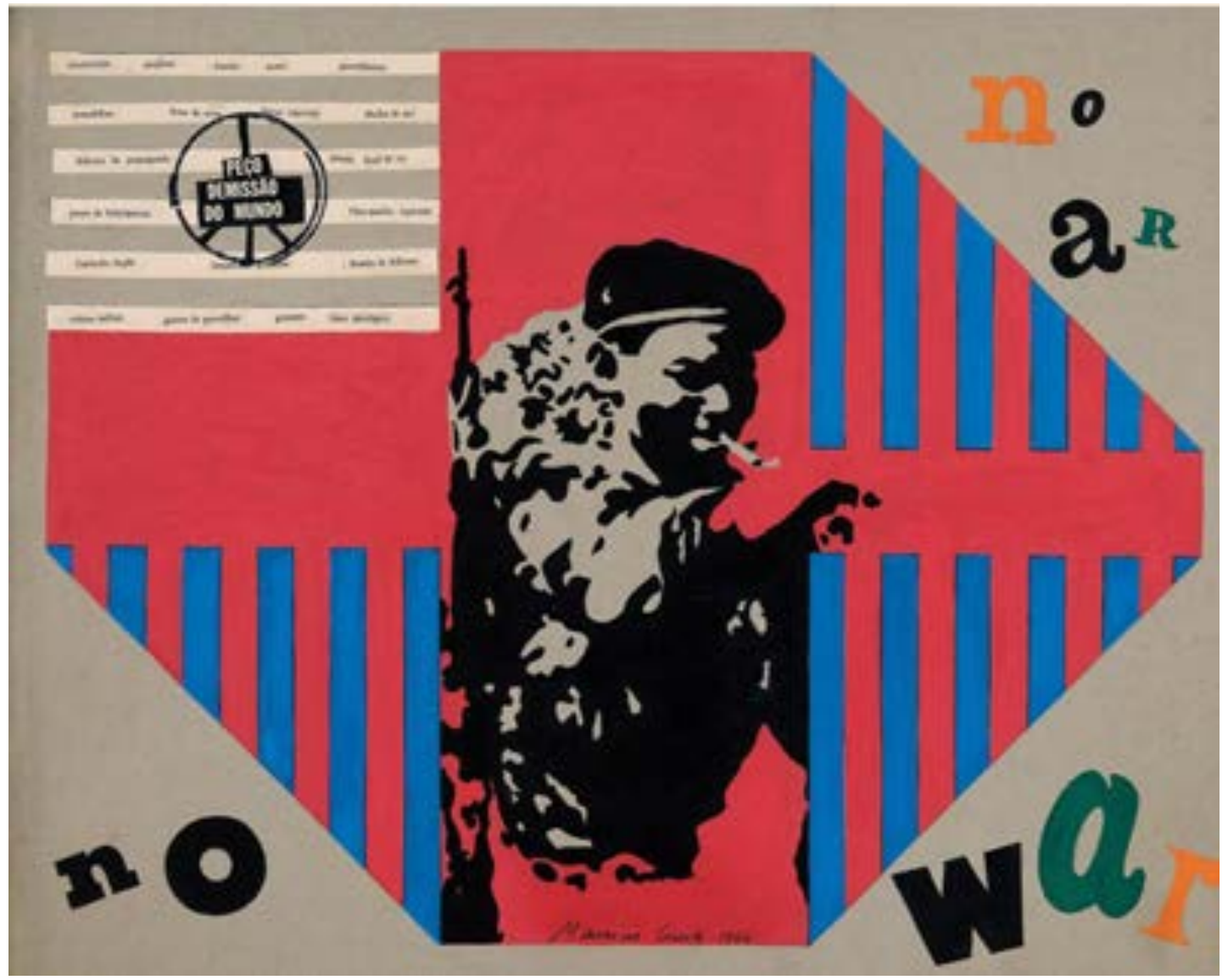

Figura 3 -Maurício Nogueira Lima, No Ar, No War, 1966. Colagem, guache e têmpera sobre cartão, $40 \times 51 \mathrm{~cm}$. 


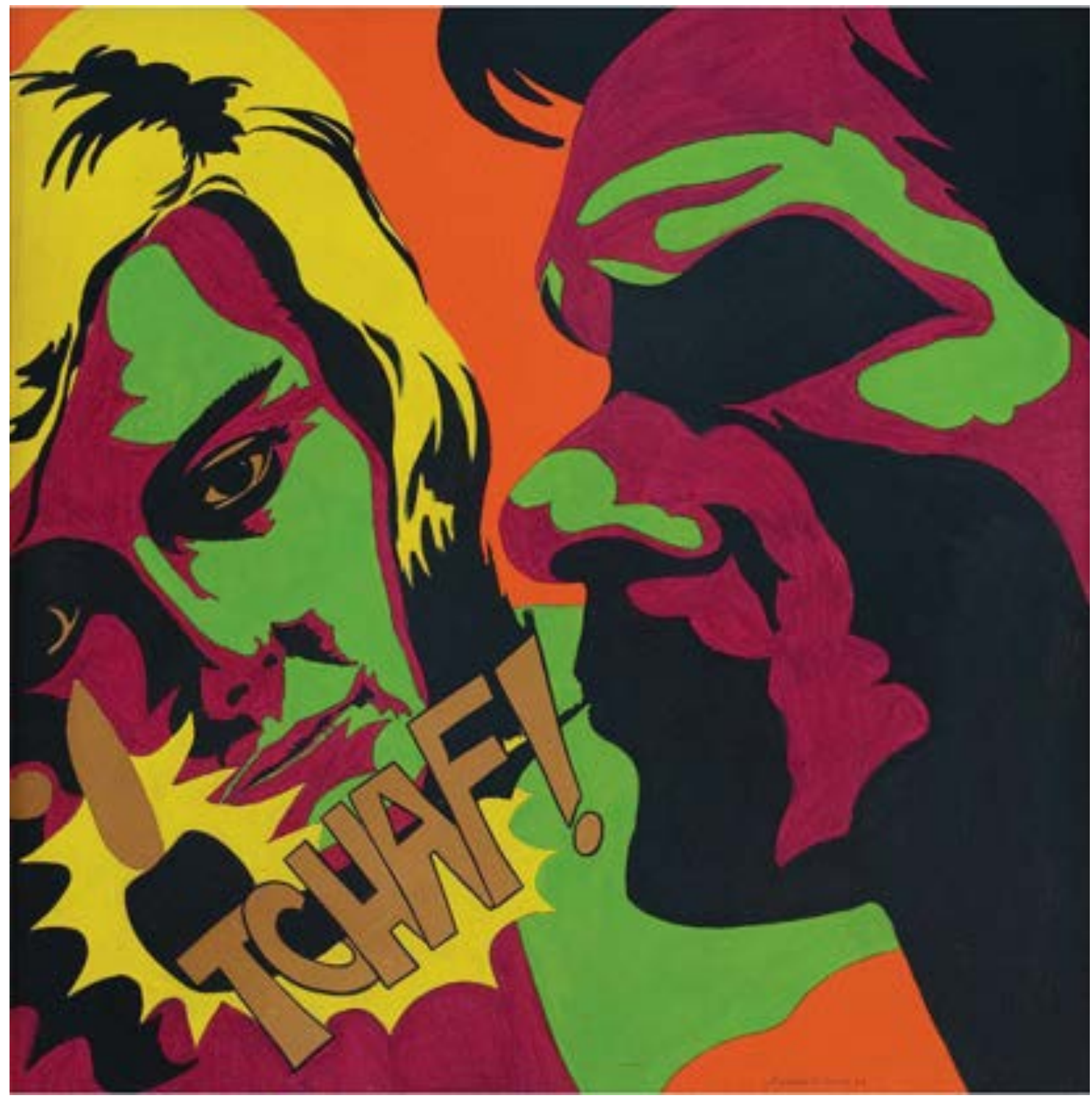

Figura 4 - Maurício Nogueira Lima, "Tchaf" positivo, 1967. Acrílica sobre cartão, 80 X $80 \mathrm{~cm}$. Col. Particular. 


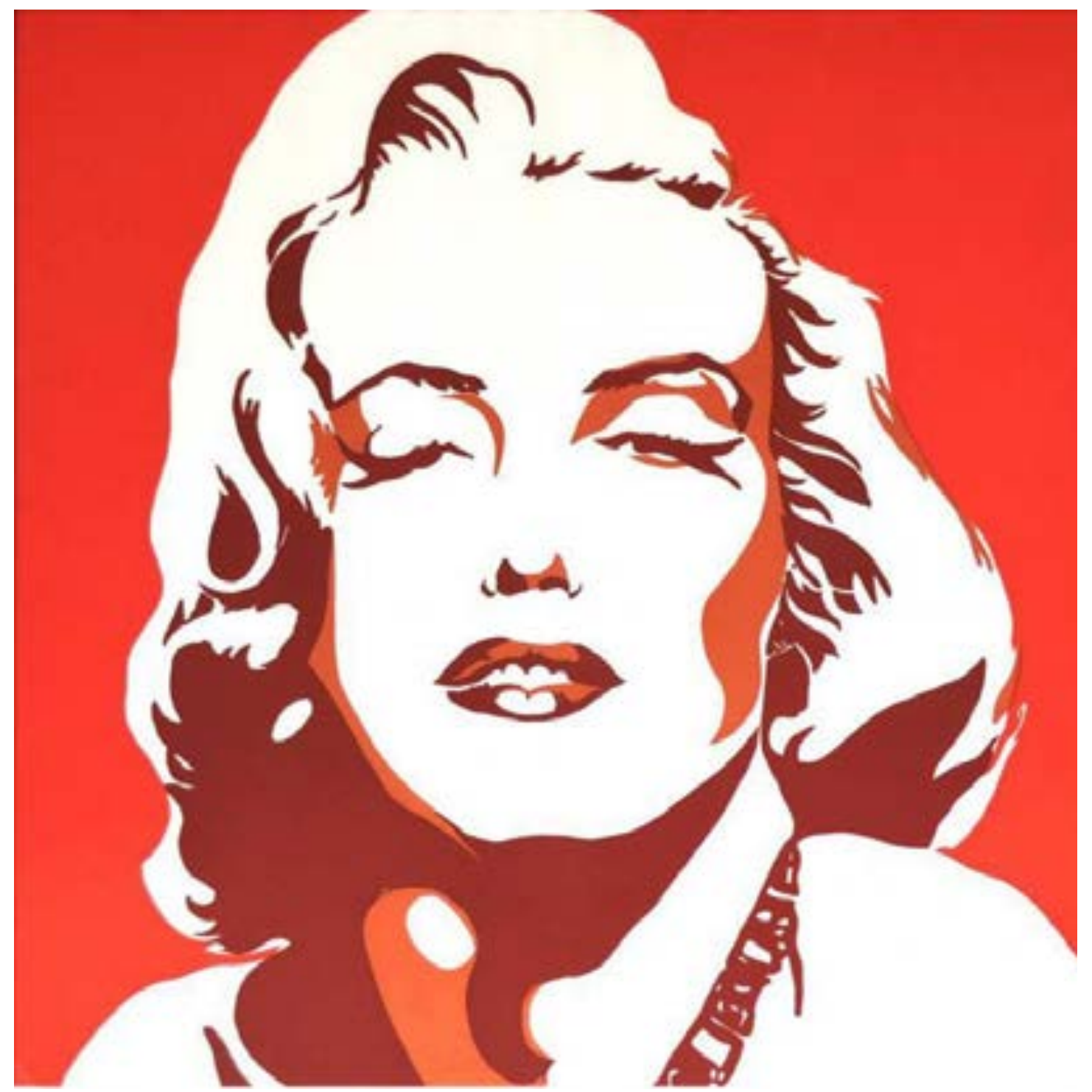

Figura 5 -Mauricio Nogueira Lima, Marilyn Monroe, 1969. Serigrafia, 73 x $73 \mathrm{~cm}$. 


\section{Arte Mágica e "Arte de Participação"}

Entre diversas tendências que emergiam dentro do Novo Realismo, cabe destacar tendências como o Realismo Mágico, o Realismo Fantástico e o Surrealismo, que se voltaram mais explicitamente para o fato de que o inconsciente constitui grande parte da vida mental do ser humano, enquanto a consciência representa parte limitada da psique. Desse modo, essas tendências estavam na chave do super-realismo, entendido conforme o Surrealismo, pois consideravam que a realidade ia além do que se passava na parcela consciente da vivência da mente ${ }^{69}$.

Para Schenberg, o peso dessas tendências teria residido no fato de corresponderem à "necessidade profunda do homem contemporâneo de superar a rigidez das barreiras que a cultura pós-renascentista ocidental estabeleceu entre a percepção positivista e outras formas oníricas, fantásticas, etc" ${ }^{, 70}$.

Tais vertentes surrealizantes foram, no plano artístico, representativas em relação ao reconhecimento do inconsciente; o que, na visão de Schenberg, foi uma das aberturas do pensamento ocidental mais significativas dos 150 anos anteriores ${ }^{71}$. Assim como o Novo Realismo, elas também surgiram da ampliação da compreensão da realidade psíquica do ser humano e, nesse sentido, contribuiriam muito para a formulação do novo humanismo.

A Arte Mágica e a Arte Fantástica estavam relacionadas aos aspectos ditos mágicos da vivência do ser humano, na medida em que os assumiam como elementos tão humanos quanto a razão. Sobre essa questão, é interessante ter em mente o que foi apontado por Carl Jung $^{72}$ :

\footnotetext{
$\mathrm{Na}$ realidade, nossa vida, dia após dia, ultrapassa em muito os limites de nossa consciência e, sem que saibamos, a vida do inconsciente acompanha a nossa existência. Quanto maior for o predomínio da razão crítica, tanto mais nossa vida se empobrecerá; e quanto mais formos aptos a tornar consciente o que é mito, tanto maior será a quantidade de vida que integraremos. A superestima da razão tem algo em comum com o poder de estado absoluto: sob seu domínio o indivíduo perece.
}

Assim como o psiquiatra suíço, também o professor Schenberg percebeu que, quanto mais valorizada a racionalidade do homem, menos espaço restava à consideração de outras

${ }^{69}$ SCHENBERG, Mario. Pensando a Arte. São Paulo Nova Stella, 1988, p. 186.

${ }^{70}$ SCHENBERG, Mario. Pensando a Arte. São Paulo Nova Stella, 1988, p. 64.

${ }^{71}$ SCHENBERG, Mario. Pensando a Arte. São Paulo Nova Stella, 1988.

72 JUNG, Carl. Memória, Sonhos, Reflexões. Rio de Janeiro: Nova Fronteira, 1970, p. 33-4. 
facetas de sua vivência mental, como o inconsciente, por exemplo. Mario Schenberg chamava a atenção, também, para o fato de que, ao lado da parcela racional da vida mental do ser humano, também estavam presentes aspectos inconscientes, imaginativos e intuitivos. Todos esses elementos faziam parte da vivência interior do homem e integravam sua percepção da realidade ${ }^{73}$.

Nesse sentido, o crítico apontou que, o "espaço da arte de uma época é talvez menos concreto que o espaço humano social e histórico contemporâneo, mas possivelmente mais rico porque inclui também de certo modo as fantasias da vida interior"74.

O real também pode se apresentar como fantástico, porquanto a fantasia também faz parte da realidade vivenciada pelo ser humano, manifestando-se com a mesma intensidade que a razão, e deveria, portanto, ser valorizada enquanto parte da relação do homem com o mundo. Para Mario Schenberg, verificar se alguma coisa existe ou inexiste não é a questão principal: importa saber "qual a relação dos homens com as coisas do mundo, quais os valores que esta ou aquela sociedade soube estruturar em sua interação com o mundo"75.

Tendo isso em mente, pode-se argumentar que, se a visão de mundo do ser humano sofreu uma ampliação, conforme observou o crítico, também foram ampliadas as fronteiras do próprio real vivenciado por ele, contemplando, além da esfera individual e da social, também a existencial e a cósmica ${ }^{76}$.

O elemento mágico não se manifestava apenas nas artes, mas também em outros campos, como a ciência. Em relação a essa questão, o crítico apontava a revisão que começava a ser feita por historiadores da ciência a respeito do perfil intelectual de Isaac Newton, bem como a contribuição metodológica do processo de pesquisa de Albert Einstein, que foi estudado por Henri Poincaré.

O Professor Schenberg enfatizou que, no Ocidente, desde o século XVII, tendeu-se a valorizar mais o raciocínio que a intuição ${ }^{77}$. Contudo, descobertas recentes à época davam

\footnotetext{
73 "Numa época em que os progressos científicos e tecnológicos levam a uma transformação frenética das condições da vida, e em que as revoluções políticas e sociais se sucedem ininterruptamente, torna-se impossível captar a realidade em seu movimento dialético rapidíssimo sem uma fantasia poderosa e aberta aos maiores paradoxos. A imaginação fantástica pode tornar-se um guia para a ação mais eficaz do que o simples raciocínio lógico no mundo de hoje e, sobretudo, no de amanhã" (SCHENBERG, Mario. Pensando a Arte. São Paulo Nova Stella, 1988, p. 186).

${ }^{74}$ SCHENBERG, Mario. Arte e tecnologia. In GULLAR, Ferreira \& PEDROSA, Mário. Arte brasileira hoje: situação e perspectivas. Rio de Janeiro: Paz e Terra, 1973, p 93.

${ }^{75}$ GOLDFARB, José Luiz. Voar também é com os Homens. São Paulo: EDUSP, 1994, p. 83.

76 SCHENBERG, Mario. Entrevista com Mario Schenberg. (Publicado originalmente na Revista Trans/Form/Ação, v. 3, p. 6-62, 1980). In Trans/Form/Ação. Marília, v.34, 2011. Edição Especial.

${ }^{77}$ SCHENBERG, Mario. Entrevista com Mario Schenberg. In Revista Brasileira de Ensino de Física, pt. 1 vol. 1, no 2, 1979. (Entrevista publicada inicialmente no jornal O Estado de São Paulo, edição de 10/12/1978), p. 63-

4. Disponível em: http://www.sbfisica.org.br/rbef/pdf/vol01a18.pd Acesso em 16/02/2012.
} 
conta de que grandes cientistas tidos como ícones intelectuais da modernidade não eram racionalistas: "Newton, talvez o maior físico que jamais houve, foi um cientista mágico por excelência, justamente ele que passava por ser o grande racionalista" ${ }^{\text {"78 }}$.

Além da Física, Isaac Newton também se dedicou à Alquimia, ao Hermetismo e à Astrologia, por exemplo. Isso mostrava que o perfil intelectual do cientista inglês, considerado o pai da ciência moderna, não era motivado pelo ideal do racionalismo ${ }^{79}$. Também Albert Einstein, que via a mente intuitiva como uma "benção sagrada, e a racional, um servo fiel" 80 e considerava que o ocidente havia se "esquecido da benção" ${ }^{81}$, mostrava que também na ciência a criatividade e a intuição eram a base das descobertas que tornavam possível o avanço do conhecimento científico.

No entender de Mario Schenberg,

a concepção do primado do raciocínio mudou muito e já se vai admitindo que a intuição é a qualidade maior do homem. O raciocínio é importante, não há dúvida. Mas primeiro a pessoa "bola", como se dizem uma certa coisa, e depois é que desenvolve aquilo racionalmente, ou seja, prova o que "bolou".

A faculdade mais importante do homem é a intuição, que se liga à fantasia. Agora é que se começa a estudar mais atentamente a vida dos homens do passado e se vê quanto essa fantasia é importante. Em Einstein isso é claríssimo ${ }^{82}$.

Com isso o crítico queria chamar a atenção para territórios vivenciais que estavam além - ou ao lado - daquele privilegiado pelo racionalismo, que teria se restringido à parcela individual, lúcida e socialmente aceita do pensamento ${ }^{83}$, na qual ficavam pouco aparentes os outros elementos já mencionados.

Importa deixar claro, como foi muito bem observado por José Luiz Goldfarb ${ }^{84}$, que embora não negasse nem se opusesse à existência da individualidade racional, Mario Schenberg não se limitava aos marcos desse racionalismo. Não interessava ao crítico abolir o individual e o social, mas acrescentar a essas esferas o existencial e o cósmico, operando, com

${ }^{78}$ SCHENBERG, Mario. Entrevista com Mario Schenberg. In Revista Brasileira de Ensino de Física, pt. 1vol. 1, no 2, 1979. (Entrevista publicada inicialmente no jornal O Estado de São Paulo, edição de 10/12/1978), p. 634. Disponível em: http:/www.sbfisica.org.br/rbef/pdf/vol01a18.pd Acesso em 16/02/2012.

79 "Einstein afirmava que suas primeiras idáias jamais se davam sob a forma de signos, números, ou qualquer outro tipo de linguagem codificada. Surgiam através de imagens cinéticas, imagens em movimento. Isto é uma espécie de iconografia interior". CAMPOS, Haroldo de. In CEDRAN, Lourdes (Coord.). Diálogos com Mario Schenberg. São Paulo: Nova Stella, 1985, p. 91.

${ }^{80}$ COHEN, Marilene. Albert Einstein. Col. Personagens que marcaram época. São Paulo: Globo, 2007.

${ }^{81}$ COHEN, Marilene. Albert Einstein. Col. Personagens que marcaram época. São Paulo: Globo, 2007.

${ }^{82}$ SCHENBERG, Mario. Entrevista com Mario Schenberg. In Revista Brasileira de Ensino de Física, pt. 1 vol. 1, no 2, 1979. (Entrevista publicada inicialmente no jornal O Estado de São Paulo, edição de 10/12/1978), p. 634. Disponível em: http:/www.sbfisica.org.br/rbef/pdf/vol0la18.pd Acesso em 16/02/2012.

${ }^{83}$ GOLDFARB, José Luiz. Voar também é com os Homens. São Paulo: EDUSP, 1994, p. 110.

${ }^{84}$ GOLDFARB, José Luiz. Voar também é com os Homens. São Paulo: EDUSP, 1994, p. 116. 
isso, um alargamento do que, segundo o mesmo autor, Schenberg teria denominado como humanismo restrito ${ }^{85}$.

Em texto sobre o artista Mario Gruber, o crítico pontuou que as diversas tendências do Realismo Fantástico, correspondiam à "necessidade profunda do homem contemporâneo de superar a rigidez das barreiras que a cultura pós-renascentista ocidental estabeleceu entre a percepção positivista e outras formas oníricas, fantásticas, etc" ${ }^{\Perp 86}$. Nesse sentido, Schenberg destacou que o Realismo Fantástico não procurava a evasão da realidade, mas "a fusão da visão positivista e naturalista com outras maneiras de apreender a realidade, para obter uma visão mais ampla e profunda da natureza e do homem cultural bem acentuado" ${ }^{\text {" }}$.

A ponte com o Oriente foi muito significativa para Mario Schenberg em relação ao aspecto teórico da Arte Mágica, pois o crítico tinha no pensamento estético chinês uma teoria da arte estabelecida há muitos séculos, que julgava não ter sido alcançada pela psicologia ocidental $^{88}$. Para o crítico, a arte continuava, para o Ocidente, como algo misterioso, na medida em este que não tinha, ainda, compreendido como se dava a forte interação entre o artista, a obra e aquele que a observava: “[p]ara o chinês a arte é uma coisa essencialmente transformadora e realizadora, algo que para o ocidental não faz sentido a não ser como 'mágica",89.

A teoria da arte chinesa, que era para o crítico uma teoria da Arte Mágica, permitia explicar certas experiências singulares que se poderia ter quando se entrava em contato com uma obra de arte. Mario Schenberg afirmava que, diante de algumas obras de arte, era possível sentir "alguma coisa que já não é a obra de arte em si" "90, efeito que se aproximaria daquele produzido pela Arte Mágica.

85 “MS [Mario Schenberg] não quer se limitar aos níveis individual e social, mas quer englobar as dimensões existenciais e cósmicas, para que se possa construir uma percepção da realidade mais plena. MS, agindo assim, não se torna um alienado sem posições próprias sobre as questões que seu tempo lhe colocou, nem tampouco um outro tipo de alienado, perdido em irracionalismos e manipulado por homens-deuses" (GOLDFARB, José Luiz. Voar também é com os Homens. São Paulo: EDUSP, 1994, p. 116).

${ }^{86}$ SCHENBERG, Mario. Pensando a Arte. São Paulo Nova Stella, 1988, p. 64.

${ }^{87}$ SCHENBERG, Mario. Pensando a Arte. São Paulo Nova Stella, 1988, p. 64.

${ }^{88}$ SCHENBERG, Mario. In CEDRAN, Lourdes (Coord.). Diálogos com Mario Schenberg. São Paulo: Nova Stella, 1985, p. 36.

${ }^{89}$ SCHENBERG, Mario. In CEDRAN, Lourdes (Coord.). Diálogos com Mario Schenberg. São Paulo: Nova Stella, 1985, p. 36. Schenberg menciona tratados como O Tao da Pintura, sem o qual não seria possível compreender a arte chinesa e, por conseguinte, a arte mágica. Uma análise mais aprofundada desse assunto será realizada no terceiro capítulo deste estudo.

${ }^{90}$ SCHENBERG, Mario. In CEDRAN, Lourdes (Coord.). Diálogos com Mario Schenberg. São Paulo: Nova Stella, 1985, p. 69. 
Segundo o pensamento estético chinês, exposto pelo crítico ${ }^{91}$, o artista passava por uma preparação para iniciar seu trabalho e produzir sua obra. No estado de espírito apropriado, o artista era capaz de entrar em contato com certas forças cósmicas, que deixariam marcas na pintura. Essas marcas poderiam ser reconhecidas pelo apreciador, se este estivesse numa atitude adequada, por meio da qual poderia entrar em contato com essas mesmas forças cósmicas. A grande experiência estética se daria, então, no alcance desse contato por intermédio das marcas deixadas na obra ${ }^{92}$.

Como já foi apontado, Mario Schenberg via nessa perspectiva uma maneira de entender a dimensão mágica da arte, que não tinha paralelos no Ocidente. Talvez, a teoria estética chinesa fosse capaz de dar conta de uma série de aspectos da arte que não tinham sido igualmente teorizados pelo Ocidente, pois não afastava aquilo que estava relacionado à intuição e, de certa forma, além da fronteira da razão, como era próprio da atitude ocidental.

Talvez, ainda, esse elemento apareça ao Ocidente como mágico justamente por estar fora da estrutura do racionalismo. E o que não havia sido compreendido pela razão surgia enquanto mistério e enquanto magia. Já o pensamento Oriental, que tinha a intuição e a imaginação como faculdades epistemológicas valorizadas, os aspectos mágicos e fantásticos eram considerados mais naturalmente como parte da realidade.

No entender de Mario Schenberg, a Arte Mágica lidava com algumas coisas que, por sua própria natureza, eram "crepusculares, e se quiser vê-las com clareza elas somem"93. Para o crítico, esses eram aspectos da realidade que só poderiam ser acessados por meio da intuição e da imaginação, pois faziam parte de estruturas fundamentais ${ }^{94}$ da realidade cuja apreensão não cabia numa arquitetura lógica.

Tendo-se em vista que, para Mario Schenberg, a atividade humana na qual havia predominância da intuição era de tipo artístico $^{95}$, foi possível supor que a arte abarcaria de modo privilegiado o elemento mágico da vida humana, embora também na ciência ele tenha grande importância.

\footnotetext{
${ }^{91}$ SCHENBERG, Mario. In CEDRAN, Lourdes (Coord.). Diálogos com Mario Schenberg. São Paulo: Nova Stella, 1985, p. 69.

92 SCHENBERG, Mario. In CEDRAN, Lourdes (Coord.). Diálogos com Mario Schenberg. São Paulo: Nova Stella, 1985, p. 69.

93 SCHENBERG, Mario. In HAMBURGUER, Amélia Império. Nota biográfica e entrevista com Mario Schenberg (novembro, 1983). São Paulo: Instituto de Física, Universidade de São Paulo, 1984, pp. 28-9.

${ }^{94}$ GOLDFARB, José Luiz. Voar também é com os Homens. São Paulo: EDUSP, 1994, p. 81.

95 "Toda atividade em que predomina a intuição é do tipo artística e, em caso contrário era do tipo científica. Mas não quer dizer que na atividade científica não haja intuição e na artística não haja inteligência. Mas essa divisão dá o tom" (SCHENBERG, Mario. In HAMBURGUER, Amélia Império. Nota biográfica e entrevista com Mario Schenberg (Novembro, 1983). São Paulo: Instituto de Física, Universidade de São Paulo, 1984, pp. 28-9).
} 
O Realismo Mágico e o Realismo Fantástico estiveram presentes nos anos de 1960 e também nos de 1970, e deram contribuições valiosas ao Novo Realismo, por meio dos elementos dos quais se discorreu acima ${ }^{96}$. Apesar de ambas as tendências terem relação com o inconsciente e os elementos mágicos da realidade, Mario Schenberg via uma diferença entre elas: para o crítico, tratava-se de dois processos criativos distintos ${ }^{97}$.

Enquanto o Realismo Mágico era caracterizado pelos aspectos já apontados, o Realismo Fantástico seria influenciado, além de todos eles, pela science fiction, e empregava constantemente "a fantasia e a imaginação como instrumentos de apreensão da realidade, ao lado da observação e do raciocínio discursivo" $"$.

Como exemplos dessas tendências, encontramos artistas como José Roberto Aguilar e Mario Gruber, com os quais Mario Schenberg manteve proximidade durante longo tempo, principalmente nas décadas de 1960 e 1970.

José Roberto Aguilar (São Paulo/SP, 1941), é pintor, escultor, videomaker, performer, músico e curador. Estudou Ciências Econômicas e foi um autodidata. Em 1956, integrou o movimento literário-performático Kaos, com Jorge Mautner e José Agripino de Paula. Participou da VII Bienal, em 1963, sendo que Mario Schenberg escreve o primeiro texto sobre sua obra no ano seguinte ${ }^{99}$. O artista participou também de Opinião 65, sendo que desde 1963 já trabalhava com elementos político-sociais. Viveu em Londres entre 1969 e 1972, bem como em Nova York, entre 1974 e 1975, tendo iniciado nesse período sua experimentação com vídeo. Em 1976, retornou a São Paulo e dedica-se também a instalação ${ }^{100}$.

Para Mario Schenberg, José Roberto Aguilar foi sempre um pesquisador na pintura, não tendo a preocupação de se alinhar com as tendências em voga, descobrindo caminhos originais e indo contra a corrente. Em 1963, sua pintura mágico-fantástica já tinha notas político-sociais e no fim dos anos de 1960, quando havia se tornado moda dizer que a pintura havia acabado, o artista estava encontrando novos caminhos por meio do que o crítico chamou de "uma pintura sem cor e sem desenho" ${ }^{101}$.

\footnotetext{
${ }^{96}$ SCHENBERG, Mario. Pensando a Arte. São Paulo Nova Stella, 1988, p. 186.

${ }^{97}$ SCHENBERG, Mario. Pensando a Arte. São Paulo Nova Stella, 1988, p. 186.

${ }^{98}$ SCHENBERG, Mario. Pensando a Arte. São Paulo Nova Stella, 1988, p. 186.

${ }^{99}$ SCHENBERG, Mario. José Roberto Aguilar. Centro Mario Schenberg de Documentação da Pesquisa em Artes - ECA/USP. Texto datado de 1964, s/p.

${ }^{100}$ ITAÚ CULTURAL. Enciclopédia de Artes Visuais Itaú Cultural. Disponível em: www.itaucultural.org.br Acesso em 02/Fev/2013.

${ }^{101}$ SCHENBERG, Mario. Pensando a Arte. São Paulo Nova Stella, 1988, p. 48.
} 
Schenberg creditou ao artista o mérito de ter chegado à sua figuração de tendência expressionista, afim ao Grupo Cobra europeu, sem ter tido conhecimento desse grupo ${ }^{102}$, por meio de "seu amor um tanto religioso pela humanidade"103. Dessa maneira, José Roberto Aguilar foi, na visão do crítico, um dos criadores da nova figuração na pintura brasileira, com seus trabalhos apresentados na VII Bienal de São Paulo, de caráter "poderosamente mágico e demoníaco"104.

O crítico destacou uma série de elementos mágico-fantásticos na pintura de Aguilar, como a inexistência do espaço vazio. Para Schenberg, as figuras do artista emergiam de um fundo repleto de energias cósmicas, podendo também essas energias estarem "entalhadas pelo sulco do contorno, como que bordando um ritmo próprio de tempo sobre uma temporalidade cósmica indefinida" ${ }^{" 105}$. O texto de Schenberg é bastante denso e repleto de pontuações a respeito dos aspectos mágicos que o crítico percebeu nos trabalhos de Aguilar.

Por volta do ano de 1963, Aguilar começou a trabalhar com elementos políticos sociais, aos quais acrescentou pesquisas na direção da pintura com spray e revólver. A respeito dessa fase do artista, Schenberg observou a obtenção de efeitos de luminosidade originais, que permitiam captar a atmosfera dos luminosos de néon, própria da metrópole ${ }^{106}$.

O crítico acompanhou, ainda, o caminho posterior do artista, que começou a trabalhar com folhas de alumínio em lugar das telas e, na fase seguinte, a deixar de lado o revólver e a utilizar um maçarico, passando a recortar a placa. Para o crítico, mais uma vez o rumo dado pelo artista à sua pesquisa caminhava contra a corrente: "agora, quando se tornou moda dizer que a pintura acabou, [o artista] descobre caminhos originais para uma pintura sem cor e sem desenho" $" 107$.

Mario Gruber (Santos SP, 1921 - Cotia SP, 2011), foi pintor, gravador, escultor, muralista e, assim como Aguilar, um autodidata. O artista começou a pintar na década de 1940. Em 1946, mudou-se para São Paulo e estudou na Escola de Belas Artes. Entre 1949 e 1951, morou em Paris, tendo recebido uma bolsa de estudos. Foi professor de gravura no MAM-SP em 1953 e também na FAAP, entre 1961 e 1964. Na década de 1970, dividia suas

${ }^{102}$ SCHENBERG, Mario. José Roberto Aguilar. Centro Mario Schenberg de Documentação da Pesquisa em Artes - ECA/USP. Texto datado de 1964, s/p.; SCHENBERG, Mario. Pensando a Arte. São Paulo Nova Stella, 1988 , p. 48.

${ }^{103}$ SCHENBERG, Mario. José Roberto Aguilar. Centro Mario Schenberg de Documentação da Pesquisa em Artes - ECA/USP. Texto datado de 1964, s/p.

${ }^{104}$ SCHENBERG, Mario. Pensando a Arte. São Paulo Nova Stella, 1988, p. 47.

${ }^{105}$ SCHENBERG, Mario. José Roberto Aguilar. Centro Mario Schenberg de Documentação da Pesquisa em Artes - ECA/USP. Texto datado de 1964, s/p.

${ }^{106}$ SCHENBERG, Mario. Pensando a Arte. São Paulo Nova Stella, 1988, p. 47.

${ }^{107}$ SCHENBERG, Mario. Pensando a Arte. São Paulo Nova Stella, 1988, p. 48. 
atividades entre ateliers em São Paulo, Olinda, Paris e Nova York, realizando também obras em espaços públicos, como os painéis para a Estação Sé do Metrô de São Paulo (1979) a Biblioteca do Memorial da América Latina (1989) ${ }^{108}$.

Schenberg apontou, em relação à trajetória de Mario Gruber, que quando começou a pintar, logo após a Segunda Guerra Mundial, o artista era de tendência neo-expressionista ${ }^{109}$. Para o crítico, em sua primeira viagem à Europa, Mario Gruber teria mudado sua orientação, em consequência do forte impacto dos grandes mestres da pintura europeia tradicional, num período em que se supunha que a pintura não apresentasse mais possibilidades de pesquisa ${ }^{110}$.

Por sua capacidade enquanto artista e por sua paciência de pesquisador, Mario Gruber alcançou um grande domínio da técnica dos grandes mestres da tradição europeia, segundo aponta o crítico $^{111}$. A técnica da pintura à óleo tinha, porém, um propósito que Mario Schenberg pontuou como metalinguístico, na medida em que o artista "aspirava a uma espécie de realismo fantástico que requeria precisamente a técnica da pintura barroca europeia para uma linguagem plástica cromática adequada, em virtude da carga cultural de suas imagens ${ }^{112}$.

$\mathrm{O}$ artista teria sentido a necessidade de mobilizar o repertório técnico da pintura à óleo com a finalidade de exprimir sua vivência da realidade contemporânea. Nesse sentido, Schenberg ressaltava o equívoco de se pensar que Mario Gruber estivesse "fazendo arte antiga":

\begin{abstract}
Na pintura de Gruber, a linguagem da pintura tradicional europeia é frequentemente um dos elementos de uma nova metalinguagem pictórica. Seria errôneo toma-la como a linguagem efetiva, como muitos fazem. Essa é a raiz de muitos malentendidos: os dos que apreciam Gruber supondo que esteja fazendo pintura antiga, e os dos que não o apreciam pelo mesmo erro de interpretação de sua metalinguagem pictórica ${ }^{113}$.
\end{abstract}

Em 1970, ano que foram escritos os dois textos analisados aqui, o crítico pontuou, também, experiências recentes de Mario Gruber, que estaria utilizando, junto à metalinguagem da técnica tradicional, novos tipos de imagem, como a fotografia, a imagem

108 ITAÚ CULTURAL. Enciclopédia de Artes Visuais Itaú Cultural. Disponível em: www.itaucultural.org.br Acesso em 02/Fev/2013.

109 SCHENBERG, Mario. Mário Gruber: um Realista Fantástico Brasileiro. Centro Mario Schenberg de Documentação da Pesquisa em Artes - ECA/USP. Texto datado de 1970, s/p.

${ }^{110}$ Mario Gruber "foi da Renascença ao Impressionismo. Rembrandt, Velasquez, Rubens Goya, Delacroix e Coubert foram os seus inspiradores, numa época em que a maioria dos críticos e teóricos supunha que a pintura estivesse agonizando, especialmente a que se ligava à grande tradição anterior ao Impressionismo" (SCHENBERG, Mario. Mário Gruber: um Realista Fantástico Brasileiro. Centro Mario Schenberg de Documentação da Pesquisa em Artes - ECA/USP. Texto datado de 1970, s/p.).

111 SCHENBERG, Mario. Pensando a Arte. São Paulo Nova Stella, 1988, p. 63.

112 SCHENBERG, Mario. Pensando a Arte. São Paulo Nova Stella, 1988, p. 64.

${ }^{113}$ SCHENBERG, Mario. Pensando a Arte. São Paulo Nova Stella, 1988, p. 64. 
televisiva, trabalhando com ampliações, sobreposições e recortes ${ }^{114}$. Essa fase significava, no entender do crítico, "uma ampliação e um aprofundamento de seu realismo fantástico anterior, refletindo o impacto do ritmo vertiginoso da história nos dias que correm"115.

Além da dimensão mágica inerente ao Realismo Fantástico, Mario Schenberg destacou um aspecto no trabalho do artista que se relaciona com o que foi dito acima, quando afirmou que Mario Gruber era capaz de impressionar tanto especialistas, quanto leigos, porquanto conseguia comunicar algo a quem observava suas obras. Isso, no entender do crítico, era próprio dos pintores de grande talento e plenos em sua maturidade ${ }^{116}$.

\footnotetext{
${ }^{114}$ SCHENBERG, Mario. Pensando a Arte. São Paulo Nova Stella, 1988, p. 64-5.

${ }^{115}$ SCHENBERG, Mario. Pensando a Arte. São Paulo Nova Stella, 1988, p. 65.

${ }^{116}$ SCHENBERG, Mario. Mário Gruber: um Realista Fantástico Brasileiro. Centro Mario Schenberg de Documentação da Pesquisa em Artes - ECA/USP. Texto datado de 1970, s/p.
} 


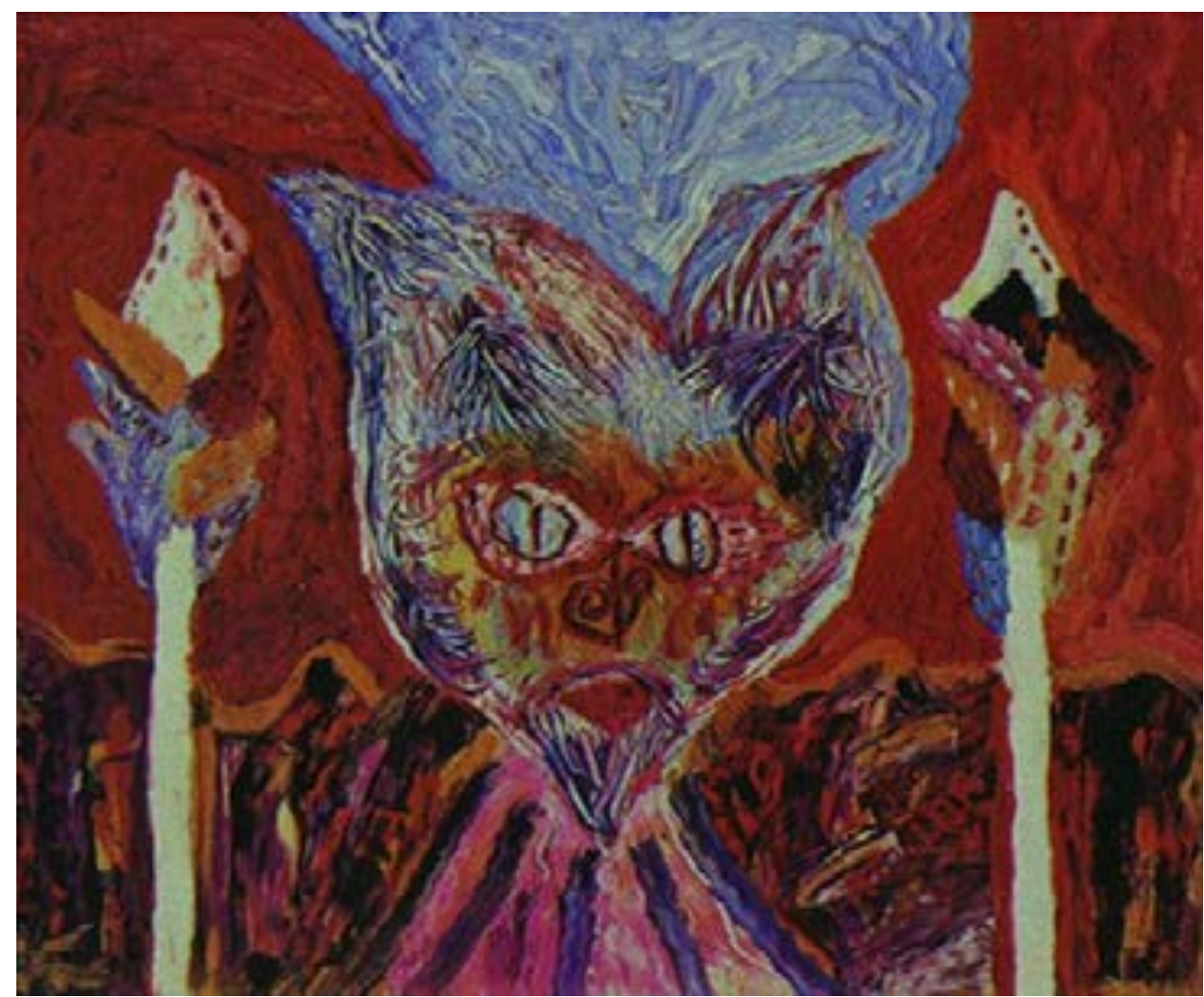

Figura 7 - José Roberto Aguilar, Sem Título, ca. 1965. Óleo sobre tela, c.i.d. 73 x $92 \mathrm{~cm}$. Reprodução fotográfica Romulo Fialdini.

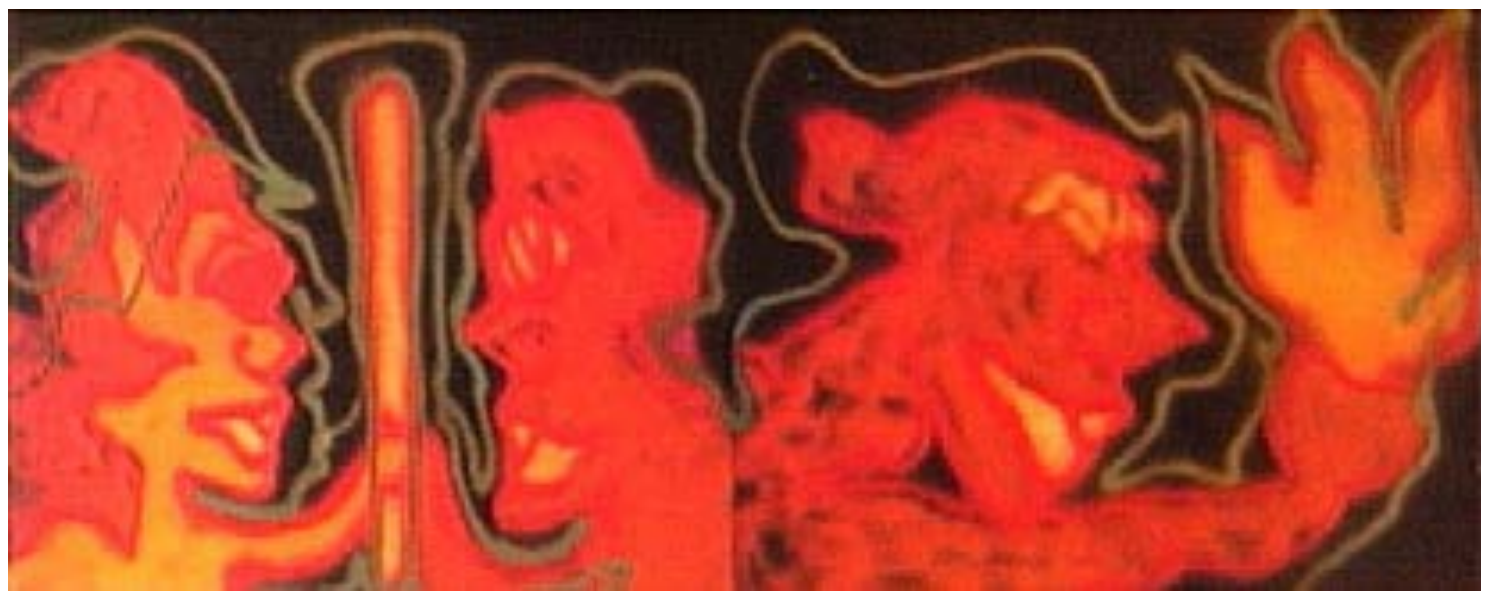

Figura 6 -José Roberto Aguilar, Imagem (Díptico) , 1967. Acrílica sobre tela, 114 x 292 cm. Reprodução fotográfica Romulo Fialdini. 


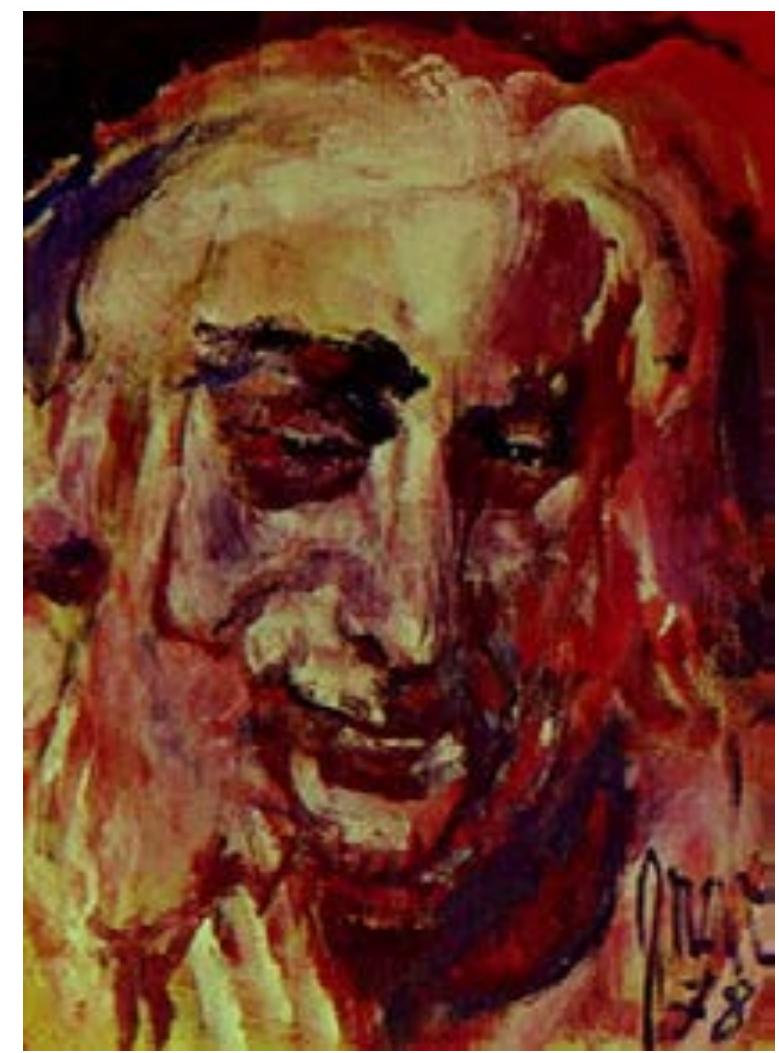

Figura 8 -Mário Gruber, Retrato de Mário Schenberg, 1978. Óleo sobre tela, c.i.d. 64 x $53 \mathrm{~cm}$. Centro Mario Schenberg de Documentação da Pesquisa em Artes - ECA/USP. Reprodução fotográfica autoria desconhecida.

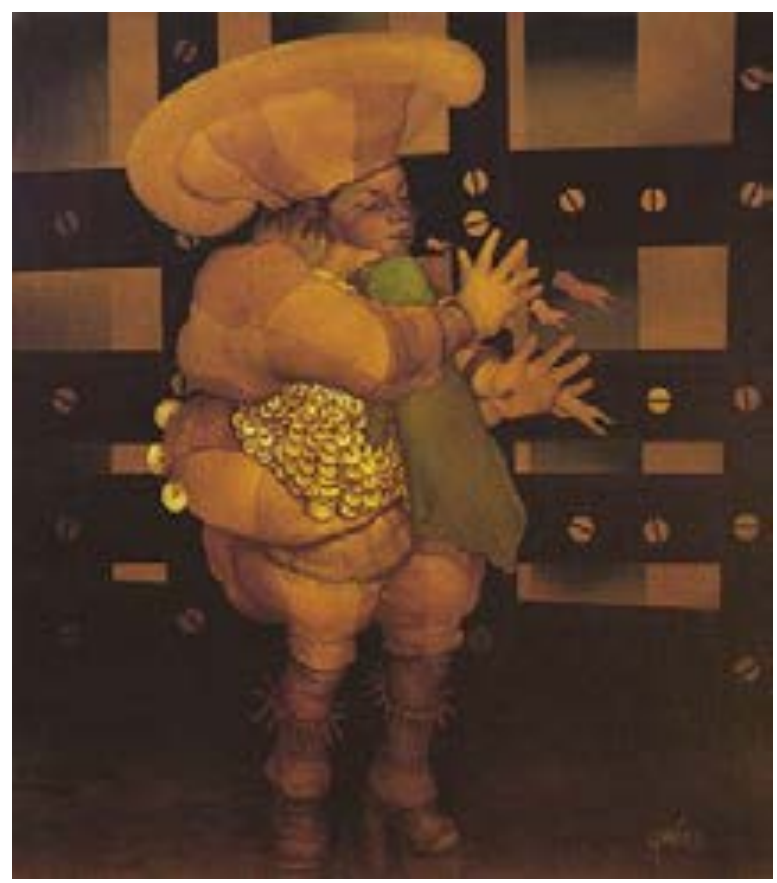

Figura 9 -Mário Gruber, Fantasiado II , 1976. Óleo e tinta acrílica sobre tela, c.i.d. 73,5 x 64 cm. Pinacoteca do Estado (São Paulo, SP). Reprodução fotográfica Rômulo Fialdini. 
Outra tendência que teve a atenção de Mario Schenberg na década de 1960 foi a chamada "Arte de Participação", como ficou conhecida. O crítico utilizava, porém, outros termos para se referir a essa tendência, conforme ficará claro adiante. Na crítica do Professor Schenberg, foram encontrados os seguintes termos, a saber, "arte ambiental", "arte sensorial", "participação sensorial" ou "multisensorial""117.

Fazendo referência ao pensamento estético chinês e a Kandinsky ${ }^{118}$ (Do espiritual na arte), Mario Schenberg observou que, quando a arte passa a ser entendida como processo de comunicação, o objeto passa a ter seu justo estatuto, porquanto deixa de ser o ponto central da arte. Desse modo, a obra detém apenas papel instrumental, em lugar de ser a finalidade da criação artística: "ser obra de arte não é característica de um objeto, é função que pode ter"119.

Não é difícil perceber que a concepção de Kandinsky e a teoria da arte chinesa (da qual já se falou brevemente) estão em proximidade, na medida em que ambas concebem a arte como um processo de comunicação espiritual entre o artista e o espectador por meio da obra de $\operatorname{arte}^{120}$.

Mario Schenberg apontou que, na arte tradicional, a obra era produzida para ser contemplada por um observador, sendo que o processo artístico era, fundamentalmente, a produção dessa obra ${ }^{121}$. Entretanto, cada vez mais o objeto passava a ser visto apenas como instrumento do processo de comunicação. Para o crítico, “depois de Marcel Duchamp, ficou claro que qualquer objeto poderia ser usado como obra de arte" $" 122$.

Citando o crítico de arte inglês Guy Brett ${ }^{123}$, Mario Scheberg apontou diferenças significativas entre a arte cinética: de um lado, na Europa e nos Estados Unidos, a tendência dos artistas era utilizar movimentos mecânicos e novas possibilidades tecnológicas; de outro, no Brasil, o suporte - o motor - dessa tendência era o próprio corpo do ser humano ${ }^{124}$. Schenberg assinala que, para o crítico inglês, as possibilidades tecnológicas não levavam de maneira incisiva ao problema da comunicação na arte em suas raízes mais profundas, como acontecia no caso da arte cinética brasileira ${ }^{125}$.

\footnotetext{
${ }^{117}$ Sobre isso, vejam-se os textos críticos de Mario Schenberg publicados no livro Pensando a Arte (São Paulo: Nova Stella, 1988) e os originais, depositados no Arquivo do Centro Mario Schenberg de Documentação da Pesquisa em Artes - ECA/USP.

${ }^{118}$ KANDINSKY, Wassily. Do Espiritual na Arte, e na pintura em particular. São Paulo: Martins Fontes, 1996.

${ }^{119}$ Mario Schenberg. Transcrição de sua intervenção na Mesa Redonda de 1971. Documento não datado, p. 4. Arquivo Histórico Wanda Svevo, Fundação Bienal (foi mantida a grafia original do texto).

${ }^{120}$ SCHENBERG, Mario. Pensando a Arte. São Paulo Nova Stella, 1988, p. 204.

${ }^{121}$ SCHENBERG, Mario. Pensando a Arte. São Paulo Nova Stella, 1988, p. 204.

${ }^{122}$ SCHENBERG, Mario. Pensando a Arte. São Paulo Nova Stella, 1988, p. 78.

${ }^{123}$ BRETT, Guy. Kinetc Art. London : Studio-Vista New York : Rienhold Book Corporation, 1968.

${ }^{124}$ SCHENBERG, Mario. Pensando a Arte. São Paulo Nova Stella, 1988, p. 78.

${ }^{125}$ SCHENBERG, Mario. Pensando a Arte. São Paulo Nova Stella, 1988, p. 78-9.
} 
Escrevendo na década de 1960, Schenberg apontou que "a ideia da participação do espectador adquiriu uma importância considerável na chamada arte lúdica e noutras formas de arte cinética durante a última década. $\mathrm{O}$ espectador passou a ser um participador, com a feliz denominação de Hélio Oiticica" ${ }^{2126}$. A teoria de Kandinsky continuaria válida em formas mais simples de participação, como o apertar de um botão ou o pisar num pedal, a fim de desencadear a resposta da obra, previamente definida pelo artista ${ }^{127}$. Nesse caso, ainda ocorria a comunicação entre o artista e o participador ${ }^{128}$.

Em outros casos, definidos por Schenberg como "formas de participação mais elevada"129, o artista não tinha o controle do resultado, podendo ser surpreendido pela resposta à proposição feita ao participador. Nesse tipo de estratégia, já não há comunicação no que diz respeito ao resultado obtido ${ }^{130}$. Quando o crítico caracterizou essas duas maneiras de participação, não tinha a intenção de colocar uma acima da outra no plano da arte, mas apenas chamar a atenção para $o$ fato de que o movimento humano era mais elevado qualitativamente $^{131}$, dado que o ser humano era, para Scheberg, logicamente anterior à máquina $^{132}$.

No entender do crítico, era preciso entender o processo artístico como uma proposta que o artista fazia ao participador, dando a ele a oportunidade de vivenciar experiências criativas. Tal proposta poderia ser constituída por um aparelho, objeto artístico, ou mesmo uma ideia ${ }^{133}$. Assim, a arte ambiental tinha por finalidade dar ao participador a possibilidade de se tornar, também, um artista, porquanto fazia com que ele experimentasse a criatividade, que não mais ficaria restrita ao processo perceptivo ${ }^{134}$. Nesse sentido, o participador pode criar algo novo e inesperado, que possa servir, até mesmo, como proposta para o $\operatorname{artista}^{135}$.

$\mathrm{Na}$ arte ambiental, o fruidor não se limitava a contemplar a obra, mas era estimulado a interagir com ela. Nesse sentido, o crítico pontuou a mudança na concepção de tempo-espaço,

\footnotetext{
${ }^{126}$ SCHENBERG, Mario. Pensando a Arte. São Paulo Nova Stella, 1988, p. 205.

127 "Naturalmente as obras em que se exigiu apenas do espectador que aperte um botão ou pise num pedal não há participação no sentido próprio. Isso não significa que o botão não possa contribuir para despertar mais o interesse do espectador e até criar um certo suspense" (SCHENBERG, Mario. Pensando a Arte. São Paulo Nova Stella, 1988, p. 204-5).

${ }^{128}$ SCHENBERG, Mario. Pensando a Arte. São Paulo Nova Stella, 1988, p. 205.

${ }^{129}$ SCHENBERG, Mario. Pensando a Arte. São Paulo Nova Stella, 1988, p. 205.

${ }^{130}$ SCHENBERG, Mario. Pensando a Arte. São Paulo Nova Stella, 1988, p. 205.

${ }^{131}$ SCHENBERG, Mario. Arte e Tecnologia. In GULLAR, Ferreira \& PEDROSA, Mário. Arte brasileira hoje: situação e perspectivas. Rio de Janeiro: Paz e Terra, 1973, p. 96.

132 SCHENBERG, Mario. Entrevista com Mario Schenberg. (Publicado originalmente na Revista Trans/Form/Ação, v. 3, p. 6-62, 1980). In Trans/Form/Ação. Marília, v.34, 2011. Edição Especial.

${ }^{133}$ SCHENBERG, Mario. Pensando a Arte. São Paulo Nova Stella, 1988, p. 204.

134 SCHENBERG, Mario. Pensando a Arte. São Paulo Nova Stella, 1988, p. 95.

135 SCHENBERG, Mario. Pensando a Arte. São Paulo Nova Stella, 1988, p. 95.
} 
que havia colocado o fruidor dentro da obra, isto é, integrado no mesmo espaço-tempo. Sobre esse ponto, Mario Schenberg ${ }^{136}$ observou que:

A arte cinética levou a uma transformação importante das relações tradicionais entre o artista e o fruidor da obra, em conseqüência da participação corporal ativa do fruidor, em vez de uma pura participação sensorial e mental como antes. Isso decorre basicamente da introdução do novo espaço-tempo da arte, que inclui tanto a obra como o fruidor de um modo integrado. O espectador ficava fora do espaço da arte renascentista, como corpo físico atuante.

No texto A Representação Brasileira na IX Bienal de São Paulo, por exemplo, Mario Schenberg ${ }^{137}$ enfatizou que os artistas Wesley Duke Lee e Hélio Oiticica chegaram à arte ambiental por caminhos diferentes:

Wesley partiu da pintura figurativa e chegou á arte ambiental por um processo de enriquecimento com elementos não pictóricos de vários tipos, utilizando também o som. Oiticica partiu de construções especiais com o emprego sutil da cor, relacionadas com suas pesquisas internacionalmente pioneiras sobre estruturas primárias.

O artista Wesley Duke Lee, um dos fundadores do Grupo Rex, em 1966, morou em Nova York entre 1952 e 1955, período de emergência do Pop norte-americano ${ }^{138}$. Em 1967 empreendia experimentações na direção da arte ambiental e na contestação do estatuto tradicional dos gêneros e do objeto artístico. A obra $O$ Helicóptero, que participou da IX Bienal, é representativa dessa vertente. Hélio Oiticica, por sua vez, havia chegado a obras como Tropicália (cuja imagem se encontra no primeiro capítulo deste estudo) a partir das pesquisas apontadas pelo crítico. A obra Relevo Espacial, de 1959, marca a diferença de direcionamento em relação a Wesley Duke Lee.

Por fim, cabe apontar que Mario Schenberg percebia na "Arte de Participação" elementos mágicos, na medida em que essa tendência, em suas diversas facetas e por diversos meios, busca uma ampliação da vivência do participador ${ }^{139}$. O crítico explicou seu ponto de vista com a referência à origem dessa tendência, entre outras coisas, ao dada e ao

\footnotetext{
${ }^{136}$ SCHENBERG, Mario Arte e Tecnologia. In GULLAR, Ferreira \& PEDROSA, Mário. Arte brasileira hoje: situação e perspectivas. Rio de Janeiro: Paz e Terra, 1973, p. 95.

${ }^{137}$ SCHENBERG, Mario. Pensando a Arte. São Paulo Nova Stella, 1988, p. 195.

${ }^{138}$ WARHOL, Andy. Catálogo de exposição. Andy Warhol: Mr. América. Catálogo de exposição. São Paulo: Pinacoteca do Estado, 2010, p. 152. Com happenings e elementos da Arte Pop, desenvolveu parte significativa de sua obra no Brasil, tendo sido um dos pioneiros dessa vertente no país (ITAÚ CULTURAL. Enciclopédia de Artes Visuais Itaú Cultural. Disponível em: www.itaucultural.org.br Acesso em 09/Nov/2011). Entre os artistas ligados a ele estavam José Resende, Carlos Alberto Fajardo, Frederico Nasser e Luiz Paulo Baravelli.

${ }^{139}$ SCHENBERG, Mario. Pensando a Arte. São Paulo Nova Stella, 1988, p. 205.
} 
surrealismo $^{140}$, em cujo horizonte estava a noção de inconsciente. Talvez, a própria concepção da arte como comunicação entre o artista e o participador, dada sua proximidade com a estética chinesa, seja um outro aspecto mágico dessa tendência.

${ }^{140}$ SCHENBERG, Mario. Pensando a Arte. São Paulo Nova Stella, 1988, p. 205. 


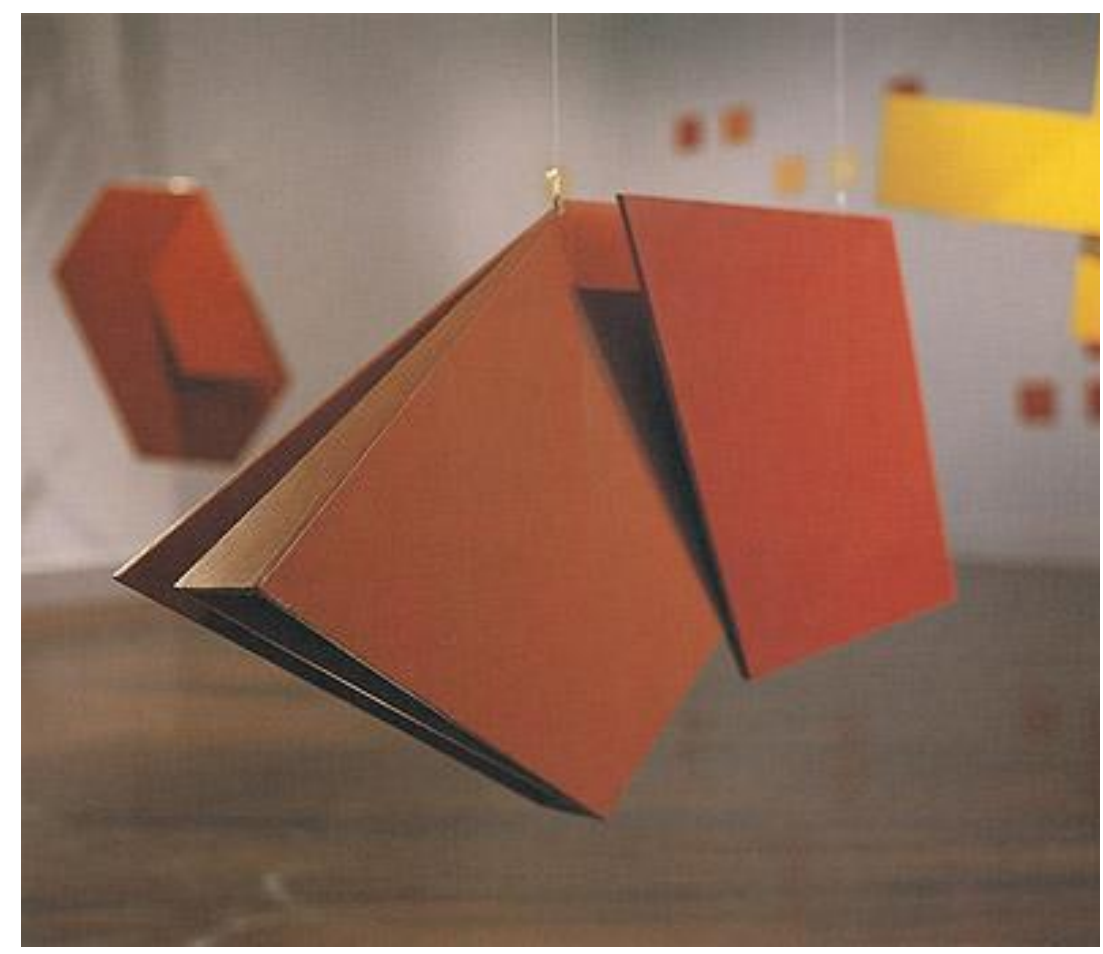

Figura 11 -Hélio Oiticica, Relevo Espacial, 1959. Acrílico sobre madeira, $16 \times 63 \times 150 \mathrm{~cm}$. Projeto Helio Oiticica (Rio de Janeiro, RJ). Reprodução fotográfica Antonio Caetano.

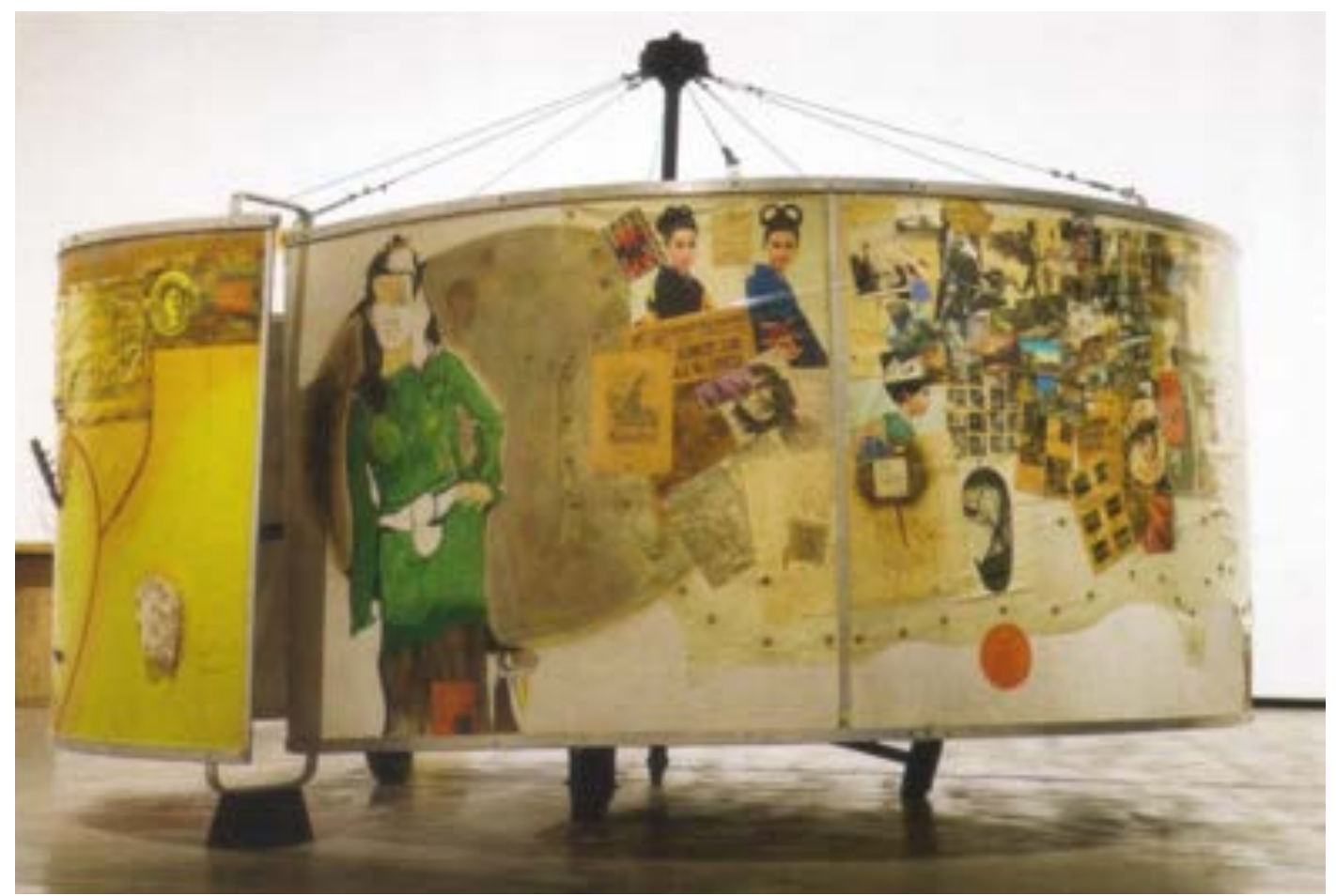

Figura 10 - Wesley Duke Lee, O Helicóptero, 1969, instalação/polimatérico, $\varnothing 400 \mathrm{~cm}$. 


\title{
Lygia Clark
}

Lygia Clark (Belo Horizonte MG 1920 - Rio de Janeiro RJ 1988), pintora a escultora, mudou-se para o Rio de Janeiro em 1947, quando iniciou seu aprendizado artístico. A artista viveu em Paris, entre 1950 e 1952. Voltando ao Brasil, foi ligada ao Grupo Frente e, posteriormente, seria uma das fundadoras do Grupo Neoconcreto. Inicialmente, Lygia Clark se dedicou à pintura. Posteriormente, trocou essa atividade pela escultura, bem como pelo objeto tridimensional ${ }^{141}$.

A artista participou das exposições Opinião 66 e Nova Objetividade Brasileira, em 1967, ambas no MAM-RJ. Voltou à Paris, onde residiu ente 1970 e 1976, período no qual lecionou na Sorbonne. Nesse ínterim, Lygia Clark se dedicou ás experiências sensoriais, com a utilização de materiais diversos. Após voltar ao Brasil, a artista se dedicou a estudar as possibilidades terapêuticas da arte sensorial ${ }^{142}$.

Em depoimento, Lygia Clark afirmou que a influência do Professor Schenberg sobre sua personalidade foi significativa:

\begin{abstract}
Eu, sem cultura nenhuma, sugava todas as conversas que com ele tive, incorporando as vivências de seu saber e, brincando, dizia: 'meus ouvidos foram fecundados por dois seres extraordinários, Mario Schenberg e Mário Pedrosa.

Nem sei o que teria realizado na minha obra sem conhecê-lo. Alguém disse uma vez que a psicanálise não era tudo o que importava, e sim os grandes encontros com pessoas como o Schenberg, no que eu estou inteiramente de acordo ${ }^{143}$.
\end{abstract}

Mario Schenberg acompanhou a trajetória da artista por longo tempo, presenciando o desdobramento das fases de seu trabalho. Escrevendo sobre a artista em 1971, Schenberg ${ }^{144}$ demonstrou muita familiaridade com a evolução de suas pesquisas.

${ }^{141}$ ITAÚ CULTURAL. Enciclopédia de Artes Visuais Itaú Cultural. Disponível em: www.itaucultural.org.br Acesso em 09/Jul/2013. É necessário apontar que, sobre a obra de Lygia Clark, existem diversos estudos, por isso, o que se pretendeu fazer, aqui, foi tratar de alguns aspectos da visão de Mario Schenberg a respeito da artista. São relevantes, principalmente, os seguintes estudos: FABRINNI, Ricardo Nascimento. O espaço de Lygia Clark. Dissertação de Mestrado. São Paulo: Universidade de São Paulo, 1991; e OLIVEIRA, Maria Alice Milliet de. Lygia Clark obra-trajeto. Dissertação de Mestrado. São Paulo: Universidade de São Paulo, 1989.

${ }^{142}$ ITAÚ CULTURAL. Enciclopédia de Artes Visuais Itaú Cultural. Disponível em: www.itaucultural.org.br Acesso em 09/Jul/2013.Para mais informações sobre Lygia Clark, veja-se o Anexo D, que contém uma breve biografia da artista.

${ }^{143}$ CLARK, Lygia. Lygia Clark. In SCHENBERG, Mario. Mario Schenberg: Entre-Vistas. São Paulo: Perspectiva, 1984, p. 75.

${ }^{144}$ SCHENBERG, Mario. Pensando a Arte. São Paulo Nova Stella, 1988. 
Para o crítico, a artista estava em profundo diálogo com os problemas universais e tensões de sua época ${ }^{145}$. O texto mencionado, que leva o nome da artista, foi pontuado por reflexões estéticas ligadas ao Novo Humanismo e aos desdobramentos do Novo Realismo.

Ao tratar da restrição ao espaço social do artista, Mario Schenberg apontou que haveria "uma dificuldade dos artistas, com raras exceções, em compreender as necessidades profundas de nossa época" 146 . Na visão do crítico, a função do artista não estava limitada "à criação de linguagens, mas consist[ia] principalmente em tornar perceptíveis, ou claramente intuitíveis coisas que pairam no ar, sobretudo novos valores em gestação"147.

A intuição seria a faculdade que permitiria ao artista perceber questões profundas, tendências vindouras e novos valores que surgiam numa civilização cujos referenciais estavam em xeque. No entender de Mario Schenberg ${ }^{148}$, vivia-se o fim de um

\begin{abstract}
período histórico iniciado após o declínio da Idade Média na Europa. Os valores desse período vão rapidamente perdendo sentido, sobretudo após o desencanto com a sociedade de consumo. (...) O esvaziamento dos antigos valores se faz sentir cada vez mais fortemente, já atingindo a fé na tecnologia. Há uma aspiração por uma "qualidade de vida", essencialmente diferente, mas ainda não definida quanto aos seus valores fundamentais. Surge assim um novo espaço para o artista de hoje, bússola para a descoberta dos valores básicos do mundo em gestação.
\end{abstract}

A partir dessa perspectiva, o crítico apontou que a obra de Lígia Clark refletia "a profunda inquietação e a crise de valores, assim como a revolta dos jovens, que caracterizaram mundialmente a década de $60 " 149$. Independente da tendência na qual o artista encontrava sua expressão, a capacidade de intuir aspectos fundamentais da realidade se fazia presente na obra de arte, de modo mais ou menos consciente.

No entender de Mario Schenberg, a contestação que foi característica da década de 1960, sobretudo por parte dos jovens, foi importante para Lygia Clark pois, vinda de um concretismo bastante rigoroso, o contato com os jovens foi capaz de abrir à artista novos caminhos: "após este contato com os jovens, ela foi se abrindo para outras coisas como a arte do corpo e a psicanálise, chegando mesmo, em Paris, a trabalhar com um psicanalista." ${ }^{150}$.

\footnotetext{
${ }^{145}$ SCHENBERG, Mario. Pensando a Arte. São Paulo Nova Stella, 1988.

${ }^{146}$ SHCNBERG, Mário. O espaço social do Artista. Arquivo Centro Mário Schenberg de Documentação e Pesquisa em Artes. Texto sem não numerado e não datado.

${ }^{147}$ SHCNBERG, Mário. O espaço social do Artista. Arquivo Centro Mário Schenberg de Documentação e Pesquisa em Artes. Texto sem não numerado e não datado.

148 SHCNBERG, Mário. O espaço social do Artista. Arquivo Centro Mário Schenberg de Documentação e Pesquisa em Artes. Texto sem não numerado e não datado.

149 SHCNBERG, Mário. Lígia Clark começara como pintora figurativa. Centro Mário Schenberg de Documentação e Pesquisa em Artes, texto nº 234, set. 1984, p. 1.

${ }^{150}$ SCHENBERG, Mario. In CEDRAN, Lourdes (Coord.). Diálogos com Mario Schenberg. São Paulo: Nova Stella, 1985, p. 39-40.
} 
Mario Schenberg destacou o pioneirismo de Lygia Clark na "Arte de Participação" com a série Bichos (1960), que marcava o deslocamento da relação do público com a obra: em lugar de observa-la, o fruidor passava a manipulá-la, participando da recriação da obra a cada movimento. As esculturas metálicas de formato geométrico, formadas por diversas placas ligadas por meio de dobradiças, eram capazes de tomar a forma que essa manipulação imprimisse a elas.

Posteriormente, a artista deixou de lado a preocupação com a durabilidade da obra de arte, ao conceber obras constituídas apenas pela vivência que o fruidor tinha ao lidar com a obra $^{151}$. "No caminhando o participador vai cortando com uma tesoura uma fita de Moebius de papel: o gesto determina uma vivência supersensorial, enquanto é criada a obra" ${ }^{252}$.

Schenberg considerava que Lygia Clark havia procurado descer até as raízes da comunicação, tendo descoberto, em sintonia com a vivência dos jovens, a eroticidade no processo da comunicação, caracterizada pela vivência sensorial desse mesmo processo ${ }^{153}$. Em obras mais recentes, a artista tinha proposto o contato entre os corpos humanos, mediado por folhas de plástico: o material não é mais a obra, esta era constituída, então, pelo próprio corpo $^{154}$. Dando um passo à frente, a artista propôs o contato direto entre os corpos humanos, dessa vez sem intermediação. Nesse momento, a proposição não partia mais da artista, mas dos próprios participantes ${ }^{155}$.

Segundo pontuou Schenberg, Lygia Clark foi a primeira artista a trabalhar sistematicamente com obras multisensoriais, que utilizavamm de recursos variados e alcançam o fruidor sob diversas formas, conforme já foi apontado ${ }^{156}$. Um bom exemplo disso talvez sejam as suas Máscaras Sensoriais.

Conforme o crítico, as experiências mais recentes da artista tinham sentido comunitário e buscavam estimular a criatividade do fruidor. Num primeiro momento, este poderia fazer o que quisesse com materiais que lhe eram fornecidos. Lygia Clark teria chamado essa experiência de "supermercado", realizando-a na Alemanha ${ }^{157}$.

Nesse ponto, Mario Schenberg ${ }^{158}$ comentou a linha evolutiva do trabalho de Lygia Clark:

${ }^{151}$ SCHENBERG, Mario. Pensando a Arte. São Paulo Nova Stella, 1988, p. 78.

${ }^{152}$ SCHENBERG, Mario. Arte e Tecnologia. In GULLAR, Ferreira \& PEDROSA, Mário. Arte brasileira hoje: situação e perspectivas. Rio de Janeiro: Paz e Terra, 1973, p. 96.

${ }^{153}$ SCHENBERG, Mario. Pensando a Arte. São Paulo Nova Stella, 1988, p. 78.

${ }^{154}$ SCHENBERG, Mario. Pensando a Arte. São Paulo Nova Stella, 1988, p. 78.

${ }^{155}$ SCHENBERG, Mario. Pensando a Arte. São Paulo Nova Stella, 1988, p. 79.

${ }^{156}$ SCHENBERG, Mario. Pensando a Arte. São Paulo Nova Stella, 1988, p. 79.

${ }^{157}$ SCHENBERG, Mario. Pensando a Arte. São Paulo Nova Stella, 1988, p. 79.

${ }^{158}$ SCHENBERG, Mario. Pensando a Arte. São Paulo Nova Stella, 1988, p. 79. 
primeiro a participação do espectador na obra de arte. Depois, a arte de proposição, que foi ficando cada vez mais avançada na medida em que se dava ao participador certos materiais para que ele fizesse qualquer coisa. Mas, agora, Lygia deu mais um passo adiante, no sentido de, em vez de fazer uma coisa individual, fazer uma criação coletiva.

$\mathrm{Na}$ fase anterior, já havia liberdade para a criação, mas ela ainda se dava em nível individual. Segundo Mario Schenberg, o que Lygia procurava, então, era estimular a criatividade coletiva, de modo que todos os friodores contribuíssem com uma parcela da criatividade empregada na realização da obra.

O crítico identificou essa instância da criatividade coletiva à construção das catedrais na Idade Média, porquanto todos os membros de certa comunidade trabalhavam na construção de uma obra única. Schenberg enfatizou que o percurso da artista foi elaborado com base nas tendências surgidas no âmbito da própria sociedade, tendo sido captadas pela artista ${ }^{159}$. Nesse sentido, para o crítico, a arte de Lygia Clark era polêmica, no sentido de que alcançava as angústias e dúvidas de seu tempo ${ }^{160}$ : "o que ela fazia em 1953 refletia, de um certo modo, aquela época. Agora, as coisas que ela apresenta refletem 1971. É uma arte ligada com os problemas mais sentidos no momento" 161 .

${ }^{159}$ SCHENBERG, Mario. Pensando a Arte. São Paulo Nova Stella, 1988, p. 79.

${ }^{160}$ SCHENBERG, Mario. Pensando a Arte. São Paulo Nova Stella, 1988, p. 79.

${ }^{161}$ SCHENBERG, Mario. Pensando a Arte. São Paulo Nova Stella, 1988, p. 79. 


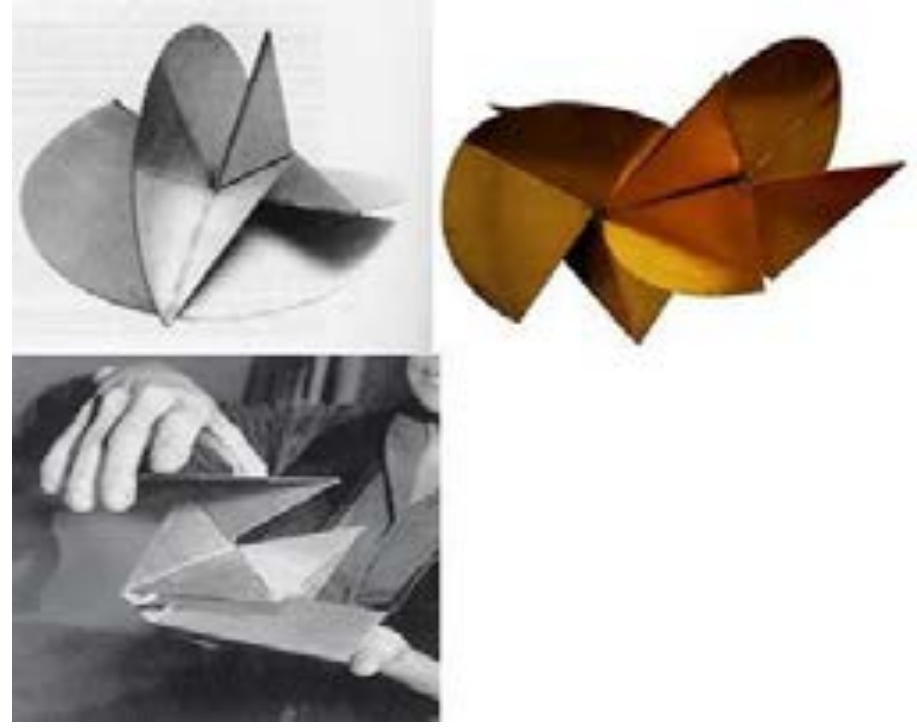

Figura 12 - Lygia Clark, Bicho, 1960, Fotografia de exposição de Lygia Clark no Rio, mesmo ano.
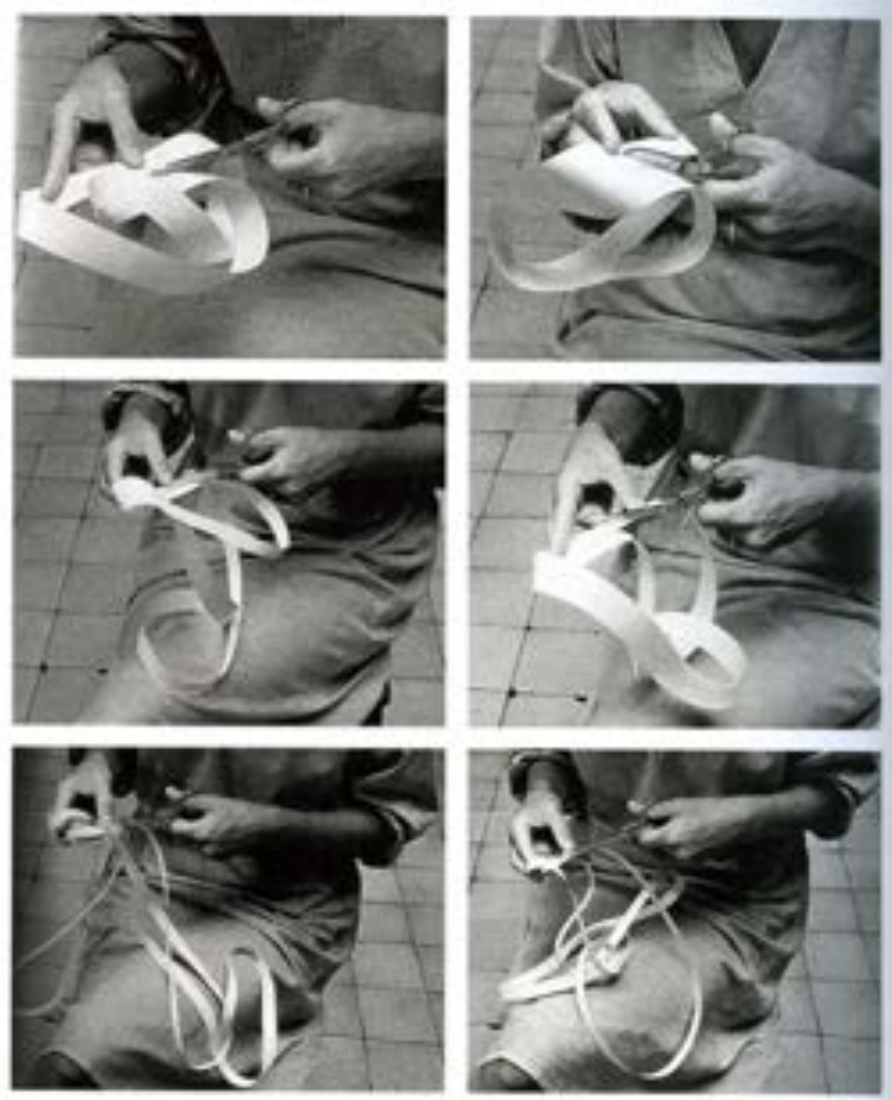

Figura 13 - Registro da performance Caminhando, feita por Lygia Clark em 1963, em que a artista recorta fita de papel 


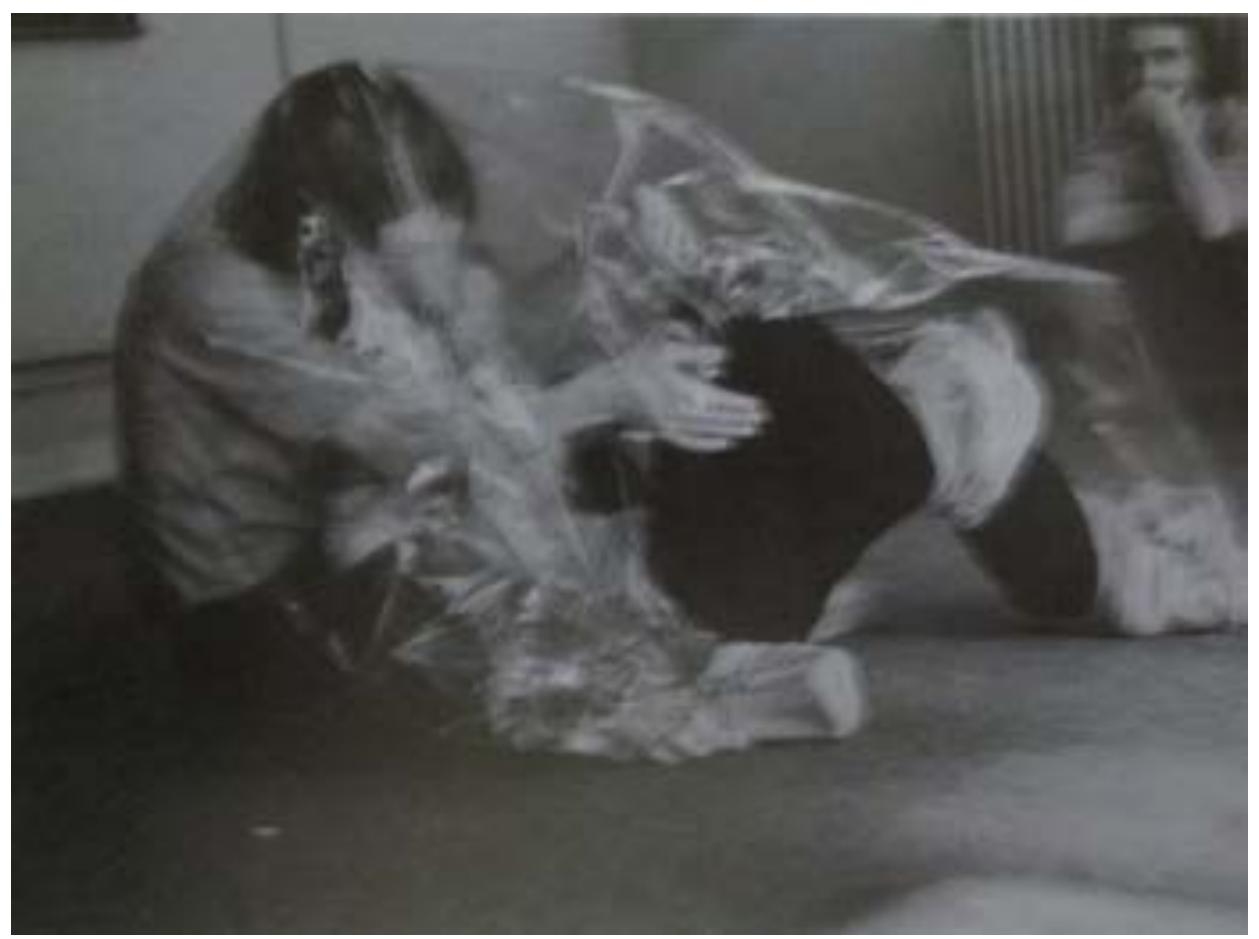

Figura 15 - Lygia Clark, Arquiteturas Biológicas: Ovo-Mortalha, 1968.

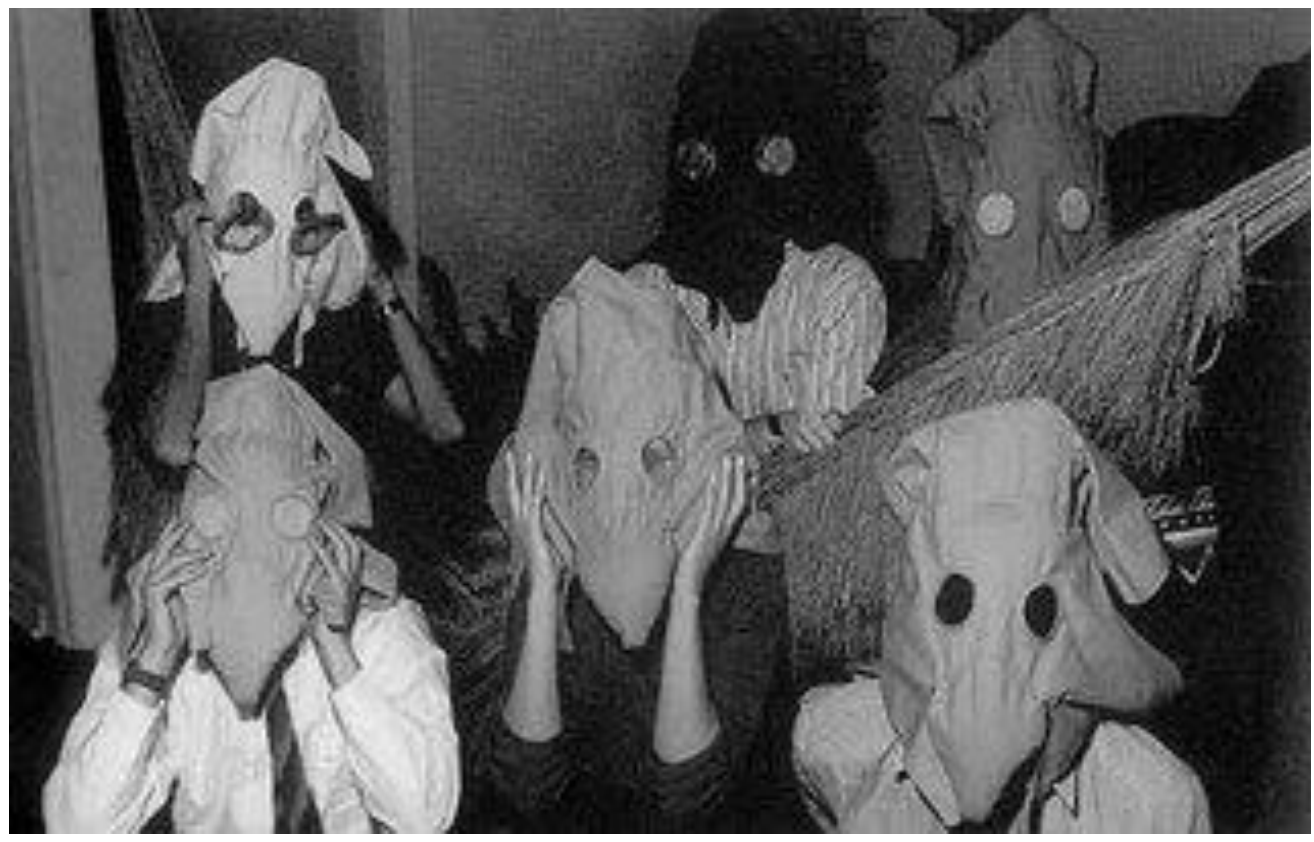

Figura 14 - Lygia Clark, Máscaras Sensoriais,1967. 


\section{Desdobramentos: a década de 1970}

A arte tem uma importância prospectiva fundamental. Ela nos ajuda a descobrir o que começa a ser de necessidade premente para a humanidade, em cada etapa nova de sua evolução. Hoje, temos necessidade de uma nova aproximação com a Natureza, da qual viemos nos afastando há séculos ${ }^{1}$.

Mario Schenberg

\section{Arte e Tecnologia, Arte Ecológica e Arte Catastrófica}

\section{Revisão dos movimentos Concreto e Neoconcreto}

$\mathrm{Na}$ década de 1970, as contribuições de tendências construtivas como o Concretismo e Neoconcretismo começaram a passar por uma revisão. Mario Schenberg escreveu o texto Concretismo e Neoconcretismo ${ }^{2}$ em junho de 1977, após ter visitado a exposição Projeto Construtivo Brasileiro na Arte - 1950-1962, que ocorreu na Pinacoteca do Estado de São Paulo, com a curadoria de Aracy Amaral ${ }^{3}$.

Schenberg, que se envolveu no debate acerca das propostas desses movimentos quando de sua eclosão, não deixou de se manifestar a respeito, reconhecendo sua importância, pois entendia que marcaram a arte brasileira ao possibilitar contribuições altamente criativas e de relevância internacional, visto que "o abstracionismo, sobretudo em sua vertente concretista [foi responsável por] desembaraçar o movimento artístico brasileiro de formas anacrônicas do naturalismo e do realismo"4.

Até o surgimento do Concretismo, no início da década de 1950, o realismo socialista soviético e a arte acadêmica difundida pelas instituições de ensino formal do país (cujo referencial era a Europa) dominavam o cenário das artes plásticas do país. Desse modo, o abstracionismo geométrico empregado pela arte concreta teria contribuído para atualizar a inteligência artística do país, cultivando

\footnotetext{
${ }^{1}$ SCHENBERG, Mario. Pensando a arte, 1988, p. 84.

${ }^{2}$ SCHENBERG, Mario. Pensando a arte, 1988, p. 215.

${ }^{3}$ AMARAL, Aracy A. (org.) Projeto construtivo na arte brasileira: 1950-1962. (catálogo de exposição) Rio de Janeiro: Museu de Arte Moderna; são Paulo, Pinacoteca do Estado, 1977.

${ }^{4}$ SCHENBERG, Mario. Pensando a arte, 1988, p.180.
} 
uma sensibilidade estética desvinculada do figurativismo e do realismo anacrônicos a que se referiu o crítico.

Apesar disso, o Professor Schenberg apontou, quando do surgimento do Novo Realismo, em 1965, que o Concretismo e o Neoconcretismo não teriam ajudado a definir melhor a feição cultural brasileira, e opinou que as novas formas de realismo teriam mais sucesso em relação a esse ponto; assim como a Pop Art fora mais eficiente que o expressionismo abstrato nos Estados Unidos ${ }^{5}$.

No entender do crítico, talvez isso tenha sido consequência do distanciamento desses movimentos em relação à condição social e cultural do Brasil enquanto país latino-americano e subdesenvolvido, cujas questões fundamentais deveriam reverberar na criação artística, entendida por Schenberg como "manifestação ideológica e social". 6

Segundo o crítico, "o surgimento dos movimentos concretista e neoconcretista foi um acontecimento de extraordinária importância da vida cultural brasileira na década dos cinquenta" ${ }^{7}$ seja em artes plásticas, literatura ou música. Essa tendência originou-se da

assimilação dos resultados das inovações da linguagem visual desenvolvidas desde o cubismo, na Europa, sobretudo por Mondrian e Malevich, assim como pela vanguarda russa, os artistas do Stijl holandês, o grupo da Bauhaus e posteriormente aprofundadas em certas direções por Max Bill e a escola suíça, e o grupo de Ulm. ${ }^{8}$

O surgimento do movimento Concretista se deu na década de 1950, catalisado pelo impacto do intercâmbio das primeiras Bienais de Arte de São Paulo, nas quais figuraram obras como Unidade Tripartida de Max Bill. Para Schenberg, essa tendência foi ao encontro da realidade brasileira que, naquele momento, estava permeada pelo otimismo desenvolvimentista e pela intensificação do processo de industrialização de São Paulo que, assim como o Rio de Janeiro, começou a tomar ares de metrópole. ${ }^{9}$

Em 1952 aconteceu a exposição do Grupo Ruptura, em São Paulo, que marcou o início do Concretismo no Brasil. Anatol Wladislaw, Lothar Charoux, Féjer, Geraldo de Barros, Leopold Haar e Luiz Sacilotto, com liderança de Waldemar Cordeiro são os nomes que figuraram no grupo. No ano seguinte, Maurício Nogueira Lima se integrou ao grupo, cuja proposta, baseada no legado do abstracionismo geométrico e do construtivismo, defendia uma arte ligada às pesquisas estéticas de

\footnotetext{
${ }^{5}$ SCHENBERG, Mario. Pensando a arte, 1988.

${ }^{6}$ SCHENBERG, Mario. Pensando a arte, 1988, p. 216-7.

${ }^{7}$ SCHENBERG, Mario. Pensando a arte, 1988, p. 215.

${ }^{8}$ SCHENBERG, Mario. Pensando a arte, 1988, p. 215.

9 ITAÚ CULTURAL. Enciclopédia de Artes Visuais Itaú Cultural. Disponível em: www.itaucultural.org.br Acesso em 09/11/2011. Mario Schenberg observou que "houve durante a década dos cinquenta uma tendência generalizada para o construtivismo, contrastando nitidamente com a tendência para o expressionismo, característica da década dos quarenta. Os movimentos concretista e neoconcretista podem mesmo ser vistos como frutos daquela tendência, provavelmente relacionada com o clima desenvolvimentista daqueles anos de otimismo e despreocupação." SCHENBERG, Mário. "Concretismo e neoconcretismo", in Pensando a arte, p. 216.
} 
ordem formal, além de um fazer artístico próximo ao trabalho industrial e fortemente ligado à racionalidade ${ }^{10}$.

No Rio de Janeiro surgiu, em 1954, o Grupo Frente, fundado por Aluísio Galvão, Carlos Val, Décio Vieira, Ivan Serpa, João José da Silva Costa, Lygia Clark, Lígia Pape e Vicent Ibberson, aos quais se juntam ainda Hélio e César Oiticica, Elisa Martins da Silveira, Emil Baruch, Frans Weissemann, Abrahan Palatnik e Ruben Ludolf. Como críticos e teóricos: Mário Pedrosa e Ferreira Gullar.

Mais abertos que o grupo paulista, os concretistas cariocas propunham pesquisas em diversas linguagens, não restringindo sua atenção ao abstracionismo geométrico. Afastando-se da “consideração da obra como 'maquina' ou 'objeto", contrariamente aos paulistas, os cariocas defendiam "maior ênfase na intuição como requesito fundamental do trabalho artístico" ". Explicitadas na Exposição Nacional de Arte Concreta (São Paulo, 1956), essas divergências levaram à ruptura neoconcreta em 1959, com a publicação do Manifesto Neoconcreto.

Mario Schenberg apontou que a diferença entre o ambiente de atuação dos concretistas de São Paulo (industrializada) e do Rio de Janeiro (capital política e administrativa do país) estava ligada à divergência de interesses entre os dois grupos. Os concretistas paulistas estavam interessados na industrialização e seu grupo "tornou-se mais fechado, em consequência da liderança autoritária de Waldemar Cordeiro e da sua "ortodoxia doutrinária" 12 Já os cariocas, nos desdobramentos neoconcretos, teriam sido capazes de "atrair melhor as tendências construtivistas generalizadas, graças à maior flexibilidade das concepções de personalidades como Mário Pedrosa, Lygia Clark, Ferreira Gullar, Frans Weissemann e Amílcar de Castro" ${ }^{\prime 13}$.

Mario Schenberg destacou que esses movimentos marcaram a arte brasileira ao possibilitar contribuições altamente criativas e de relevância internacional, pois "o abstracionismo, sobretudo em sua vertente concretista" foi responsável por "desembaraçar o movimento artístico brasileiro de formas anacrônicas do naturalismo e do realismo" ${ }^{14}$. Em lugar de reverberações dos movimentos artísticos estrangeiros, aparentemente sem contribuições significativas, limitadas às adaptações de poéticas à realidade brasileira, os movimentos concreto e neoconcreto foram base de contribuições muito criativas que reverberaram internacionalmente, o que teria colocado o Brasil em condição de igualdade de participação nas pesquisas artísticas da época.

${ }^{10}$ ITAÚ CULTURAL. Enciclopédia de Artes Visuais Itaú Cultural. Disponível em: www.itaucultural.org.br Acesso em 09/11/2011.

${ }^{11}$ ITAÚ CULTURAL. Enciclopédia de Artes Visuais Itaú Cultural. Disponível em: www.itaucultural.org.br Acesso em 09/11/2011.

${ }^{12}$ SCHENBERG, Mario. Pensando a arte, 1988, p. 216.

${ }^{13}$ SCHENBERG, Mario. Pensando a arte, 1988, p. 216.

${ }^{14}$ SCHENBERG, Mario. Pensando a arte, 1988, p. 215, p. 180. Apesar de sua atuação política como militante do Partido Comunista, Mário Schenberg se distancia da orientação artística proposta por ele: o Realismo Socialista Soviético. Em lugar disso, o autor apoiava as vanguardas, pois elas seriam abertas às demandas mais recentes do momento histórico, capazes de responder melhor ao desafio da descoberta dos valores em gestação. Cf. SHCNBERG, Mário. O espaço social do Artista. Arquivo Centro Mário Schenberg de Documentação e Pesquisa em Artes. Texto sem não numerado e não datado. 
A década de 1950 viu surgir o Concretismo e, em reação a esse movimento, o Neoconcretismo, em meio ao clima de otimismo desenvolvimentista do governo de Juscelino Kubitschek. Enquanto os concretistas paulistas estavam imersos em uma aposta na racionalidade e na tecnologia, os cariocas do movimento neoconcreto estavam direcionados para pesquisas mais abertas e intuitivas, explorando novas possibilidades sinalizadas pelas pesquisas dos artistas do grupo.

No final dos anos de 1950 se deu o declínio desses dois movimentos com a emergência da nova figuração e do Novo Realismo, que se desenvolveram em várias vertentes. Pesquisas de artistas que participaram do grupo neoconcreto conviviam com as tendências das Vanguardas Brasileiras da década de 1960, desembocando, por exemplo, na Arte de Participação e na Arte Ambiental.

Tendo-se em mente a importância dada por Mario Schenberg à intuição, foi possível apontar que houve atritos entre o crítico e o Waldemar Cordeiro, na medida em que o artista propunha que a arte concreta afastasse a criatividade do fazer artístico, valorizando a racionalidade e a tecnologia ${ }^{15}$. Sobre esse debate, Schenberg ${ }^{16}$ fez o seguinte relato:

Eu e o Cordeiro éramos pessoas com muitas arestas, mas havia uma certa estimulação mútua, ele estimulava muito as idéias artísticas, às vezes ele exagerava na questão de ver com clareza as coisas. [...] Ele exagerava no método científico, queria construir uma Ciência da Arte; mas não há nem Ciência da Ciência, que dirá das Artes. Tem-se que correr riscos. Ele queria ver a Arte como Ciência. Acho que isso não é correto.

No entender de Mario Schenberg, nem sempre era possível ver tudo com clareza, algumas coisas, por sua própria natureza, eram "crepusculares, e se quiser vê-las com clareza elas somem"17. Para o crítico, esses eram aspectos da realidade que só poderiam ser acessados por meio da intuição e da imaginação, pois faziam parte de estruturas fundamentais ${ }^{18}$ da realidade cuja apreensão não cabia numa arquitetura lógica.

Para o Professor Schenberg, Waldemar Cordeiro parecia querer tomar a intuição pela inteligência, na medida em que apostava no método científico para compreender coisas que, para o crítico, o pensamento lógico não alcançava, a fim de construir uma "Ciência da Arte" ${ }^{19}$. Nesse debate com o artista, Schenberg formulou de modo bastante significativo sua visão da importância da intuição tanto na arte, quanto na ciência:

${ }^{15}$ Cf. AMARAL, Aracy A. (org.) Projeto construtivo na arte brasileira: 1950-1962. (catálogo de exposição) Rio de Janeiro: Museu de Arte Moderna; são Paulo, Pinacoteca do Estado, 1997.

${ }^{16}$ SCHENBERG, Mario. In HAMBURGUER, Amélia Império. Nota biográfica e entrevista com Mario Schenberg (Novembro, 1983). São Paulo: Instituto de Física, Universidade de São Paulo, 1984, pp. 28-9.

17 SCHENBERG, Mario. In HAMBURGUER, Amélia Império. Nota biográfica e entrevista com Mario Schenberg (Novembro, 1983). São Paulo: Instituto de Física, Universidade de São Paulo, 1984, pp. 28-9.

${ }^{18}$ José Luiz Goldfarb observou que "[a] intuição é como um mergulho nas entranhas da realidade, de modo que as estruturas mais fundamentais da realidade sejam apreendidas além do uniforme e superficial, além do conhecido no presente" (GOLDFARB, José Luiz. Voar também é com os Homens. São Paulo: EDUSP, 1994, p. 81).

19 SCHENBERG, Mario. In HAMBURGUER, Amélia Império. Nota biográfica e entrevista com Mario Schenberg (Novembro, 1983). São Paulo: Instituto de Física, Universidade de São Paulo, 1984, pp. 28-9. 
Eu dizia a ele que em toda atividade em que predomina a intuição é do tipo artística e, em caso contrário era do tipo científica. Mas não quer dizer que na atividade científica não haja intuição e na artística não haja inteligência. Mas essa divisão dá o tom $^{20}$.

No texto Mário Schenberg: incentivador e crítico, o artista Maurício Nogueira Lima ${ }^{21}$ fez um relato sobre a proximidade de Mario Schenberg com os artistas do grupo concretista, inclusive Waldemar Cordeiro:

muitas vezes, no fim das nossas discussões, saíam brigas terríveis; principalmente porque a pessoa que liderava o nosso grupo, o Waldemar Cordeiro, era uma pessoa irascível e nervosa, além de ter grandes choques com o Schenberg por problemas artísticos e políticos.

Enquanto Mário defendia a intuição na arte, mesmo no concretismo, os artistas desse grupo não concordavam com ele, opinando que sua arte "tinha algo de ciência, de mental".

A questão da intuição na arte e na ciência, sobre a qual o crítico de arte tratou em vários momentos, mostrou-se importante no que diz respeito ao posicionamento de Schenberg em relação ao Concretismo. Destacou-se a proximidade entre a as objeções de Mario Schenberg à proposta concretista e a motivação da ruptura dos artistas cariocas, que daria origem, com o Grupo Frente, ao Neoconcretismo, na medida em que davam mais ênfase à "intuição como requisito fundamental do trabalho artístico"22.

Foi possível perceber que, apesar de procurar compreender como Waldemar Cordeiro pensava a arte e a ciência, Mario Schenberg escreveu apenas um texto sobre seu trabalho, em 1963, período em que o artista operava uma reavaliação em seus procedimentos, após a crise que havia levado ao fim o Grupo Ruptura ${ }^{23}$. Nesse momento, o artista passou do rigor da construção a partir de conceitos matemáticos a uma produção que evidenciava uma perspectiva "mais ancorada nas reais condições sociais enfrentadas no Brasil" ${ }^{24}$. Essas preocupações estiveram presentes até o fim da década de 1960, juntamente com a influência da Pop Art e do Nouveau Réalisme, que marcaram a ambientação artística de então ${ }^{25}$.

${ }^{20}$ SCHENBERG, Mario. In HAMBURGUER, Amélia Império. Nota biográfica e entrevista com Mario Schenberg (Novembro, 1983). São Paulo: Instituto de Física, Universidade de São Paulo, 1984, pp. 28-9.

${ }^{21}$ LIMA, Maurício Nogueira. Mário Schenberg: incentivador e crítico", in AJZENBERG, Elza (org.). Col. Schenberg - Arte e Ciência. São Paulo, vol. I, 1995, p. 41

${ }^{22}$ ITAUU CULTURAL. Enciclopédia de Artes Visuais Itaú Cultural. Disponível em: www.itaucultural.org.br Acesso em 09/11/2011.

${ }^{23}$ LIMA, Mônica Rodrigues de. Schenberg e o concretismo de Waldemar Cordeiro. In CENTRO MARIO SCHENBERG DE DOCUMENTAÇÃO DA PESQUISA EM ARTES. Documentação: arte e ciência. (coord. Elza Ajzenberg). São Paulo: Centro Mario Schenberg/ECA-USP, 1994, p. 292.

${ }^{24}$ ITAUU CULTURAL. Enciclopédia de Artes Visuais Itaú Cultural. Disponível em: www.itaucultural.org.br Acesso em 09/11/2011.

${ }^{25}$ ITAÚ CULTURAL. Enciclopédia de Artes Visuais Itaú Cultural. Disponível em: www.itaucultural.org.br Acesso em 09/11/2011. 
Mario Schenberg enfatizou que, nessa fase de seu trabalho, Waldemar Cordeiro havia rompido com a tradição cubista sem deixar, porém, de permanecer fiel aos postulados essenciais da arte concreta, o que teria resultado num concretismo sem formas geométricas rigorosas ${ }^{26}$. Apesar de ainda lidar com estruturas seriais, repetição de elementos simples, retículas e outros elementos da arte concreta, o artista os empregava, então, "com muita flexibilidade e liberdade, sem o rigorismo antigo. $" 27$.

O crítico pontuou, também, que Waldemar Cordeiro havia retomado uma dimensão artesanal da arte ao voltar à utilização do "clássico pincel" ${ }^{\text {, }}$, de maneira feliz. Esse redirecionamento do artista resultou, para Schenberg, numa pintura simples e límpida, que combinava temas construtivos bem delimitados a uma realização cromática espontânea ${ }^{29}$. Mario Schenberg ${ }^{30}$ expressou de maneira sintética sua posição otimista em relação à nova direção tomada por Waldemar Cordeiro ao destacar que:

As experiências de Cordeiro são promissoras e provam que uma arte não expressionista e não simbólica pode fugir ao racionalismo ensimesmado e ao intelectualismo, assim como ao puro expontaneísmo, e se realizar por imagens em si, de validez autônoma.

Em 1967, em comentário referente à representação brasileira na IX Bienal de São Paulo, o crítico observou que as pesquisas feitas pelo artista nos anos anteriores o tinham levado à Arte Concreta Semântica, que ficou conhecida como Pop-Creta. Para Schenberg, o trajeto de Waldemar Cordeiro partiu do concretismo e "passou de modo surpreendente ao novo realismo, na sua fase popcreta" ${ }^{\natural 1}$, aliando o rigor do concretismo à temática do Pop brasileiro.

No entender do crítico, os artistas do movimento concreto de São Paulo, bem como os neoconcretistas do Rio de Janeiro, deram importantes contribuições para o Novo Realismo brasileiro nos anos de $1960^{32}$. Além de Waldemar Cordeiro, Schenberg aponta outros artistas, como Maurício Nogueira Lima e, entre os cariocas, estão Lygia Clark e Hélio Oiticica ${ }^{33}$.

Em 1968, Waldemar Cordeiro começou a fazer experimentações com computadores, voltando à atitude inicial evidenciada acima, com a qual Mario Schenberg não concordava. Em 1970, o artista afirmou em depoimento:

Volto ao ponto de partida. A arte concreta o que fazia: digitalizava a imagem, números, superfícies com quantidades, relacionava essas quantidades, programava os quadros. A execução era artesanal apenas porque não havia indústria alguma que

\footnotetext{
${ }^{26}$ SCHENBERG, Mario. Pensando a arte, 1988, p. 15.

${ }^{27}$ SCHENBERG, Mario. Pensando a arte, 1988, p. 15.

${ }^{28}$ SCHENBERG, Mario. Pensando a arte, 1988, p. 15.

${ }^{29}$ SCHENBERG, Mario. Pensando a arte, 1988, p. 15.

${ }^{30}$ SCHENBERG, Mario. Pensando a arte, 1988, p. 16.

${ }^{31}$ SCHENBERG, Mario. Pensando a arte, 1988, p. 194.

${ }^{32}$ SCHENBERG, Mario. Pensando a arte, 1988, p. 194.

${ }^{33}$ SCHENBERG, Mario. Pensando a arte, 1988, p. 194.
} 
quisesse fazer isso e os artistas não tinham dinheiro para pagar [...] Os quadros concretos poderiam ter sido executados por uma tipografia, por uma indústria, por uma máquina, porque eles tinham na sua base um programa numérico - note bem como a arte digitalizada" 34 .

Um exemplo dessa fase é o trabalho A Mulher que não é BB, de 1971, no qual o artista utilizou um computador para digitalizar uma imagem fotográfica. Nesse período, o artista trabalhou junto a José Luíz Aguirre e Roberto Serafim Estevam, na Universidade de São Paulo. Para sua realização, o computador escolhia ao acaso vinte por cento dos dígitos, "atribuindo-lhes valores também ao acaso" ${ }^{35}$.

Mario Schenberg não comentou essa fase do $\operatorname{artista}^{36}$, mas mencionou a exposição Arteônica ${ }^{37}$, ocorrida no ano de 1971 (da qual a obra acima fez parte) em sua participação na Mesa Redonda Internacional de Críticos de Arte na XI Bienal de São Paulo ${ }^{38}$. No entender do crítico, a tecnologia no campo da arte estava sendo mal utilizada. Mesmo reconhecendo que os novos materiais eram úteis nas técnicas já existentes (novas tintas, pigmentos industrializados, etc), o crítico julgava que sua presença, por si só, não significava "sair tanto assim da arte tradicional"39.

O crítico aprofundou sua colocação afirmando que pintar uma tela usando novas tintas, por exemplo, não seria tão inovador quanto utilizar diretamente a luz. Da mesma forma, realizar um desenho com a utilização de um computador se ele pudesse ter sido feito à mão sem prejudicar sua proposta significava usar essa tecnologia sem necessidade ${ }^{40}$.

Dito de outra forma, fazer com as novas tecnologias o que seria possível realizar antes delas e, principalmente, sem elas, significava deixar de aproveitar o verdadeiro potencial criativo aberto por seu desenvolvimento. A tecnologia, ao abrir caminhos que iam além dos novos materiais, tornava possível o que antes dela era irrealizável enquanto forma de expressão artística ${ }^{41}$. Para Schenberg, essa seria a maneira mais significativa de aproximar Arte e Tecnologia.

${ }^{34}$ COSTA, Helouise; BOEHRINGER, Vivian. WALDEMAR Cordeiro: a ruptura como metáfora. São Paulo: Cosac \& Naify : Centro Universitário Maria Antônia, 2002, p. 28.

35 ITAÚ CULTURAL. Enciclopédia Itaú Cultural de Arte e Tecnologia. Disponível em: http://www.cibercultura.org.br Acesso em 20/05/2013.

${ }^{36}$ LIMA, Mônica Rodrigues de. Schenberg e o concretismo de Waldemar Cordeiro. In CENTRO MARIO SCHENBERG DE DOCUMENTAÇÃO DA PESQUISA EM ARTES. Documentação: arte e ciência. (coord. Elza Ajzenberg). São Paulo: Centro Mario Schenberg/ECA-USP, 1994, p. 292.

${ }^{37}$ A exposição Arteônica: o uso criativo de meios eletrônicos nas artes teve lugar na FFAP, no ano de 1971 (ITAÚ CULTURAL. Enciclopédia Itaú Cultural de Arte e Tecnologia. Disponível em: http://www.cibercultura.org.br Acesso em 20/05/2013).

${ }^{38}$ Mario Schenberg. Transcrição de sua intervenção na Mesa Redonda de 1971. Documento não datado, p. 3. Arquivo Histórico Wanda Svevo, Fundação Bienal (foi mantida a grafia original do texto).

${ }^{39}$ Mario Schenberg. Transcrição de sua intervenção na Mesa Redonda de 1971. Documento não datado, p. 3. Arquivo Histórico Wanda Svevo, Fundação Bienal (foi mantida a grafia original do texto).

${ }^{40}$ Mario Schenberg. Transcrição de sua intervenção na Mesa Redonda de 1971. Documento não datado, p. 3. Arquivo Histórico Wanda Svevo, Fundação Bienal (foi mantida a grafia original do texto).

${ }^{41}$ Mario Schenberg. Transcrição de sua intervenção na Mesa Redonda de 1971. Documento não datado, p. 3. Arquivo Histórico Wanda Svevo, Fundação Bienal (foi mantida a grafia original do texto). 
Conforme o depoimento do artista, suas experiências realizavam por meio de computadores o que a Arte Concreta já fazia artesanalmente antes de surgir a possibilidade da "arte digitalizada" Desse modo, percebeu-se que, para o crítico, as experiências de Waldemar Cordeiro nessa fase não levavam ao limite as novas possibilidades abertas pela tecnologia, porquanto realizaria algo que já era possível antes de sua existência.

Outro elemento apontado por Schenberg foi que "a compreensão da arte como manifestação ideológica foi muito fraca tanto no concretismo quanto no neoconcretismo, em toda a década de cinquenta"43, sendo que nos anos de 1960, a consciência política voltaria à tona com as tendências da nova figuração. Mesmo não concordando com a falta de comprometimento do Concretismo em relação à condição de subdesenvolvimento do país, Mario Schenberg não deixou de apoia-lo como movimento de vanguarda, na medida em que suas propostas se apresentavam como renovadoras no cenário das artes plásticas daquele contexto.

A relação que se evidenciou entre arte e tecnologia foi muito importante para a compreensão do que representou a produção artística tanto da década de 1960, quanto da seguinte. Em Caminhos da Arte Atual ${ }^{44}$, Schenberg assinalou que, apesar de não se poder ver com clareza a natureza desse novo período artístico revolucionário, já era possível afirmar que a tecnologia faria parte de seu horizonte de referências ${ }^{45}$.

Refletindo sobre a crise da cultura ocidental, Schenberg afirmou que esta não estaria conseguindo se adaptar à Revolução Industrial mais recente, caracterizada pelo desenvolvimento da tecnologia eletrônica, cibernética e atômica; e que uma mudança tão profunda não deixaria de afetar toda a cultura moderna ${ }^{46}$. Assim como as máquinas da Primeira Revolução Industrial substituíram em parte o trabalho físico humano, as da Segunda Revolução possibilitaram a substituição do trabalho mental. O desenvolvimento dessa tecnologia direcionou-se à transformação radical das telecomunicações (rádio, televisão, etc), além das tensões geradas em nível mundial pela questão nuclear, que trouxe a ameaça da destruição de toda a humanidade por meio da bomba atômica ${ }^{47}$.

$\mathrm{Na}$ visão do crítico, as reverberações desse quadro na produção artística foram a emergência de tendências dadaístas e a utilização cada vez maior de recursos elétricos e eletrônicos. Nesse sentido, o neodadaísmo se daria em chave crítica, como protesto em relação aos rumos do desenvolvimento tecnológico, enquanto as formas nascentes de arte vinculadas à tecnologia em ascensão dependiam dela como meio de expressão. Para Mario Schenberg era "importante observar que o emprego dos

${ }^{42}$ COSTA, Helouise; BOEHRINGER, Vivian. WALDEMAR Cordeiro: a ruptura como metáfora. São Paulo: Cosac \& Naify : Centro Universitário Maria Antônia, 2002, p. 28.

${ }^{43}$ SCHENBERG, Mário. Pensando a arte, p. 216.

${ }^{44}$ SCHENBERG, Mario. Pensando a arte, 1988, p.203. Publicado originalmente com o título de Caminhos da Arte de Hoje, no Jornal do Brasil (Rio de Janeiro), em 27 de setembro de 1969.

${ }^{45}$ SCHENBERG, Mario. Pensando a arte, 1988.

${ }^{46}$ SCHENBERG, Mario. Pensando a arte, 1988.

${ }^{47}$ SCHENBERG, Mario. Pensando a arte, 1988. 
novos $^{48}$ recursos tecnológicos na arte corresponde às novas necessidades de comunicação artística, que não poderiam ser atendidas pelas técnicas e materiais tradicionais"49.

Os artistas, vivenciando o surgimento de novas tecnologias, sentiam a necessidade de incorporá-las, a fim de abrir novos caminhos expressivos. Estando presente na realidade daquele momento histórico, com seus avanços e impasses, a tecnologia tornava-se um aspecto que pairava no horizonte dos artistas, que eram capazes de perceber essa nova realidade, fosse quando ainda se apresentam como valores em gestação, fosse quando já se mostravam plenamente à luz ${ }^{50}$.

A tecnologia estava sendo cada vez mais incorporada ao fazer artístico da década de 1960 (e também posteriormente), tanto como temática quanto como meio de expressão (novos materiais e meios de comunicação utilizados). Já por ocasião da VIII Bienal de São Paulo, Mario Schenberg fez observações sobre isso, ao destacar a obra de vários artistas. Efísio Putzelu, por exemplo, expôs "uma série de esculturas-aparelhos simbolizando os vários sentidos e o cérebro. Nelas utiliza eletrônica, som, cheiro de ozona, oscilógrafos, etc. [...] abrindo novos horizontes para a escultura brasileira" ${ }^{51}$.

Em outro exemplo, Schenberg ${ }^{52}$ constatou que mesmo em modalidades artísticas como a pintura, também foram introduzidos novos recursos, a fim de possibilitar a abertura de caminhos para a experimentação:

[...] Aguilar fez experiências muito conhecidas de pintura com spray e revólver. Essas técnicas lhe permitiram obter efeitos de cor originais e captar a atmosfera peculiar dos luminosos de neon, tão típica das metrópoles atuais.

A relação entre a arte e a tecnologia surgiu, ainda, no horizonte temático dos artistas de vanguarda, na medida em que apontava para a crise gerada pelo desenvolvimento tecnológico na civilização ocidental. Tensões como o perigo atômico, a supervalorização da máquina em detrimento da dignidade humana e a deterioração das relações interpessoais nas grandes metrópoles foram alguns dos aspectos levantados por Mario Schenberg nos textos que escreveu nesse momento.

As considerações feitas pelo crítico sobre obras de Calabrone, artista italiano radicado no Brasil, são de extrema relevância, pois mostram algumas das questões presentes não apenas no horizonte dos artistas, mas também na percepção de Mario Schenberg a respeito daquele momento histórico. Sobre as obras, Schenberg ${ }^{53}$ afirmou que:

A superação do mecanismo, através de uma síntese com o orgânico, constitui sem dúvida um dos problemas básicos do homem, neste fim do século XX. Corremos o perigo da robotização e até da destruição se não conseguirmos impregnar o mundo mecânico com a nossa organicidade humana. [...]

${ }^{48}$ SCHENBERG, Mario. Pensando a arte, 1988.

${ }^{49}$ SCHENBERG, Mario. Pensando a arte, 1988, p. 204.

${ }^{50}$ SCHENBERG, Mario. Pensando a arte, 1988.

${ }^{51}$ SCHENBERG, Mario. Pensando a arte, 1988, p. 195.

${ }^{52}$ SCHENBERG, Mario. Pensando a arte, 1988, p. 47.

${ }^{53}$ SCHENBERG, Mario. Pensando a arte, 1988, p. 39-40. 


\begin{abstract}
Algumas pinturas recentes de Calabrone têm como que um caráter profético. Nelas vemos peças corroídas de mecanismos desfeitos. [...] Calabrone aborda assim de uma forma pessoal o problema máximo de nossa época: a possibilidade de uma guerra nuclear. Aí se apresenta de modo mais terrível a luta do orgânico com a energia descontrolada do inorgânico em nosso tempo. [...] Não o empolga o espírito de aventura, nem está possuído pelo senso apocalíptico, mas percebe com intuição e sensibilidade as dimensões inebriantes e apavoradoras do momento que vive a espécie humana.
\end{abstract}

O trecho aludiu a aspectos fundamentais do pensamento de Mario Schenberg: o Novo Humanismo e a ameaça da guerra nuclear como consequência dos rumos seguidos pelo desenvolvimento tecnológico num sentido distante da dignidade humana. Além disso, o crítico, depois de discorrer em tom apocalíptico a respeito das pinturas do artista, faz questão de esclarecer que não se tratava de arrebatamento nem empolgação de sua parte, mas de aspectos da realidade captados intuitivamente ${ }^{54}$.

Mario Schenberg pontuou que Calabrone vinha se dedicando à pintura e ao objeto, buscando novas formas de expressão. $\mathrm{O}$ artista apresentava esculturas semelhantes a criaturas robotizadas, que estariam situadas numa "luta dialética da fascinação e da repulsa pela civilização mecânica" 55 . A presença maciça de novos recursos tecnológicos evidenciava a necessidade de encontrar novos meios de expressão que, sem dúvida, guardavam relação com as mudanças da realidade vivenciada pelos artistas, em decorrência do próprio desenvolvimento tecnológico.

A relação entre arte e tecnologia dizia respeito, conforme já foi apontado, à ameaça trazida pela corrida armamentista do período pós-guerra, na medida em que, ao mesmo tempo em que proporcionava novos caminhos à arte, também tinha um aspecto ameaçador. Notou-se que, para Schenberg, desenvolvimento e valorização da tecnologia caminharam a passos mais largos que a valorização do ser humano ${ }^{56}$. Por aí se pôde constatar que a relação entre arte e tecnologia motivou o crítico a pensar aspectos do Novo Humanismo.

Outro sentido dessa temática pôde ser visto a partir das relações humanas na metrópole contemporânea, quando Schenberg ${ }^{57}$ comentou que os quadros de Alice Brill,

\footnotetext{
pintados sem preocupação direta de crítica social, têm contudo um alto valor de acusação, porque abordam uma das questões mais dolorosas de nossa época. Nas grandes metrópoles, onde o nível econômico é mais elevado, os seres humanos se encontram numa situação cada vez mais aflitiva de solidão e ensimesmamento.
}

Para Schenberg, a pintura de Alice Brill "nasce de uma vivência autêntica e profunda do ambiente da metrópole paulista, especialmente do que a caracteriza como grande centro industrial brasileiro" 58 .

\footnotetext{
${ }^{54}$ SCHENBERG, Mario. Pensando a arte, 1988.

${ }^{55}$ SCHENBERG, Mario. Pensando a arte, 1988, p. 39.

${ }^{56}$ SCHENBERG, Mario. Pensando a arte, 1988.

${ }^{57}$ SCHENBERG, Mario. Pensando a arte, 1988, p. 34.
} 
Tendo em vista que, para o crítico, o artista lidava com aspectos fundamentais da realidade (conscientemente ou não), observou-se que a relação entre arte e tecnologia foi um aspecto marcante da crítica de Mario Schenberg durante as décadas de 1960 e 1970. Nesse período o crítico apontava sua presença tanto nos recursos utilizados pelos artistas (luzes neon, vídeo-tape, etc.) quanto na vivência da metrópole e da condição humana em meio a uma sociedade na qual o desenvolvimento tecnológico corria o risco de suplantar o ser humano.

${ }^{58}$ SCHENBERG, Mario. Pensando a arte, 1988, p. 41. 


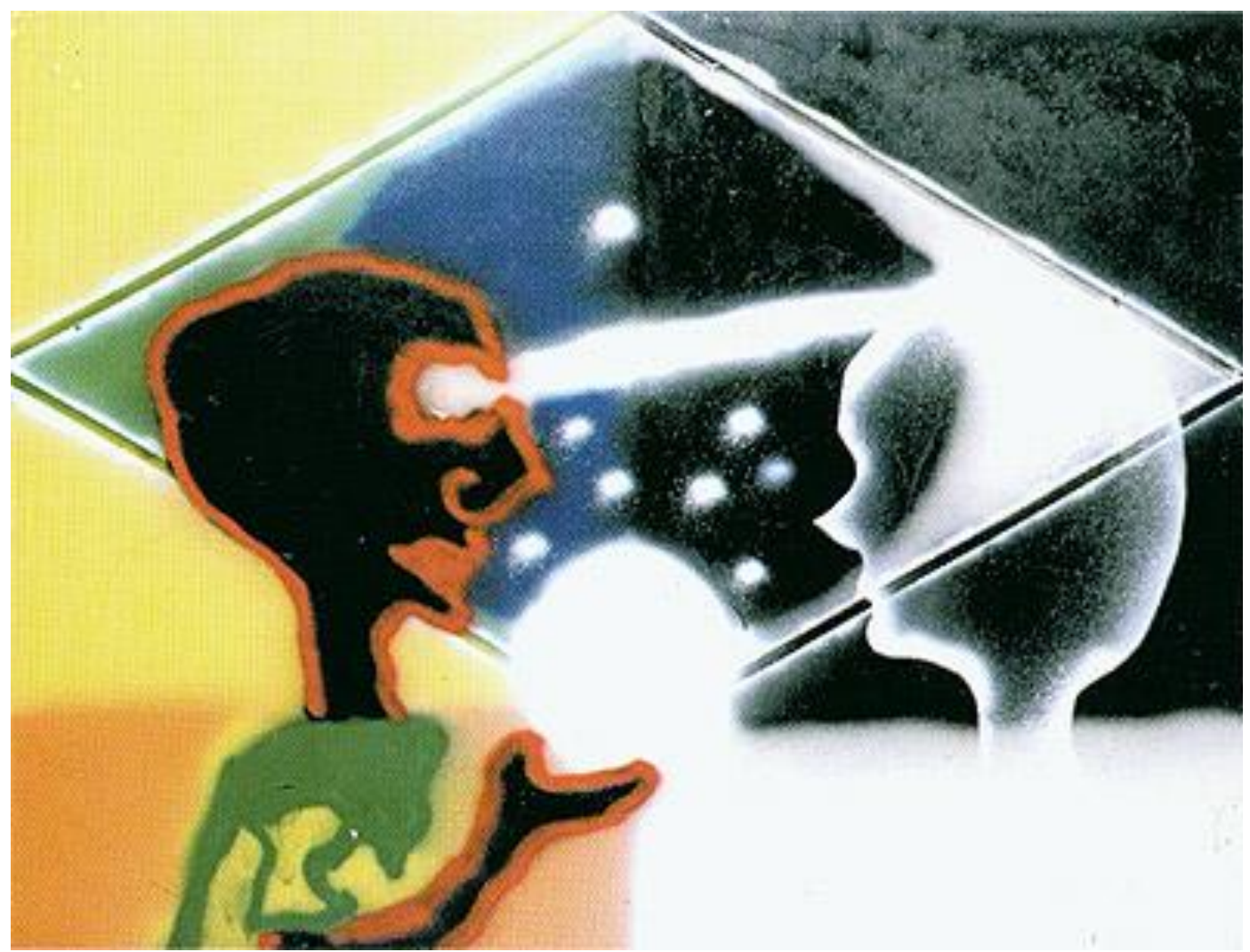

Figura 1 -José Roberto Aguilar, Série do Futebol II , 1966. Spray sobre tela, 114 x $146 \mathrm{~cm}$. Coleção MAC-USP

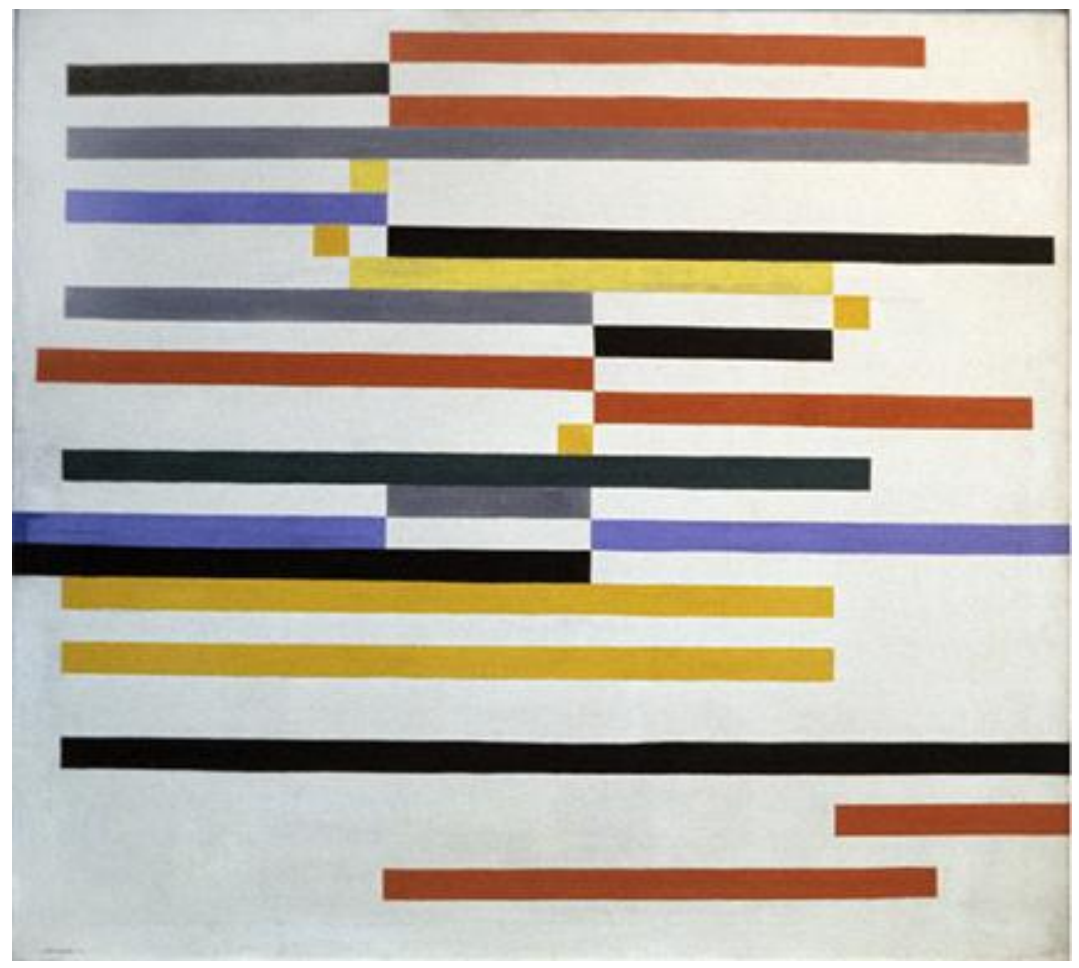

Figura 2 - Waldemar Cordeiro, Movimento, 1951. Têmpera sobre tela, 90.2 x $95 \mathrm{~cm}$. Coleção MAC-USP. 


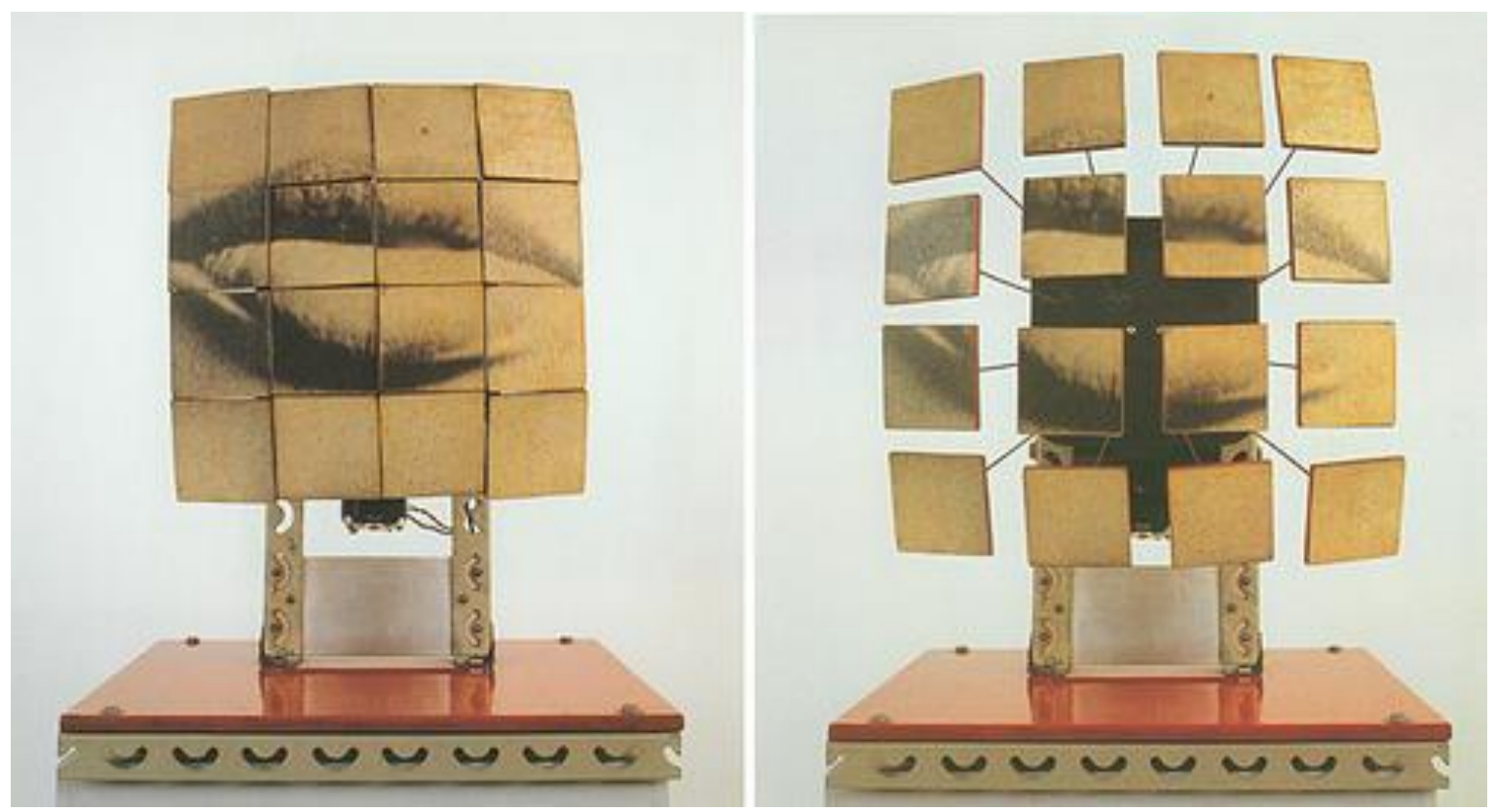

Figura 5 - Waldemar Cordeiro, O Beijo, 1967. Coleção MAC-USP.

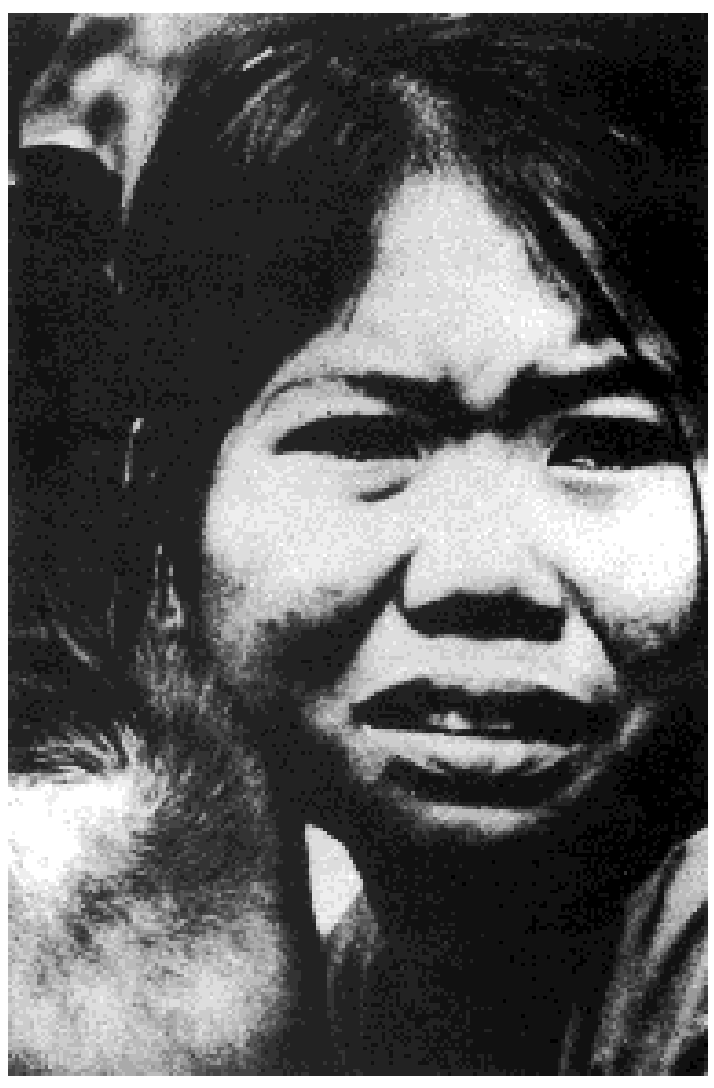

Figura 4 - A mulher que não é B.B., 1971.

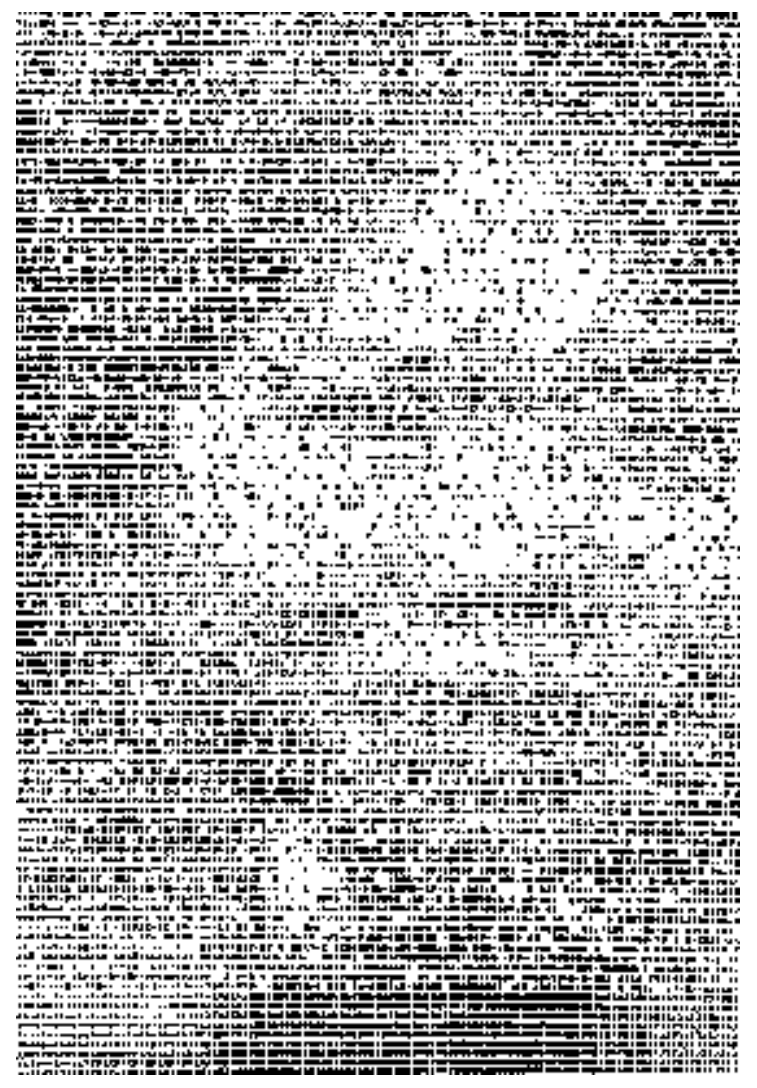

Figura 3 - Waldemar Cordeiro, José Luiz Aguirre / Estevam Roberto Serafim, USP, A mulher que não é B.B., 1971, computer graphic, $30,5 \times 45,5 \mathrm{~cm}$, Coleção particular. 


\section{Contribuições do Grupo Santa Helena}

Outra movimentação à qual Mario Schenberg esteve atento nos anos de 1970 foi o início da revisão da contribuição de artistas e movimentos das décadas anteriores, principalmente dos anos de 1940, 1950 e 1960. O crítico escreveu sobre o Grupo Santa Helena, demonstrando muita familiaridade com a ambientação e os interesses dos artistas do grupo, reconhecendo que apesar de algumas características comuns, cada um deles tinha sua própria personalidade definida em suas obras, tanto enquanto estiveram reunidos, como nos caminhos posteriores que tomaram.

O surgimento do Grupo Santa Helena se deu com a associação de artistas-artesãos, provenientes do proletariado paulista, na década de 1930, como consequência da reunião espontânea dos mesmos, sem propósitos estéticos estabelecidos (a não ser o vínculo profissional através do ofício de pintura de parede), através da utilização de um mesmo espaço como escritório-ateliê no antigo edifício Santa Helena, então localizado na Praça da Sé, em São Paulo. O primeiro a instalar-se foi Francisco Rebolo em meados de 1934, estabelecendo ali seu escritório de empreiteiro e artistadecorador. Em 1935 começou a pintar, mesmo ano em que Mário Zanini passou a dividir com ele a sala. Algum tempo depois, Zanini alugou uma sala ao lado, assim constituindo o espaço utilizado pelo grupo. Logo se somaram à dupla Manoel Martins, Fulvio Pennacchi, Aldo Bonadei, Clóvis Graciano, Alfredo Volpi, Humberto Rosa e Rizzotti ${ }^{59}$.

A peculiaridade do grupo residia na origem humilde de seus integrantes que possuíam uma formação acadêmica bastante diversa daquela trilhada pelos modernistas. Ficaram conhecidos por suas excursões com a finalidade de pintar ao ar livre, geralmente lugares periféricos onde predominava a paisagem cotidiana da rotina do proletariado (temática predominante na obra do grupo) ${ }^{60}$.

Schenberg conheceu Alfredo Volpi e os outros artistas do Grupo Santa Helena por intermédio de Bruno Giorgi, no início dos anos de 1940. O crítico, que estreitou laços de amizade com esses dois artistas, também participou das aulas de desenho que aconteciam no palacete Santa Helena nesse período, chegando, por vezes, a ceder sua própria residência para que as aulas ocorressem ${ }^{61}$.

\footnotetext{
${ }^{59}$ AJZENBERG, Elza Maria (org.). Operários na Paulista: MAC USP e artistas artesãos. Apresentação Horacio Lafer Piva, Elza Maria Ajzenberg; introdução Daisy Valle Machado Peccinini de Alvarado. São Paulo: MAC, 2002.

${ }^{60}$ AJZENBERG, Elza Maria (org.). Operários na Paulista: MAC USP e artistas artesãos. Apresentação Horacio Lafer Piva, Elza Maria Ajzenberg; introdução Daisy Valle Machado Peccinini de Alvarado. São Paulo: MAC, 2002.

${ }^{61}$ OLIVEIRA, Alecsandra Matias. Schenberg: Crítica e Criação. São Paulo: EDUSP, 2011.
} 


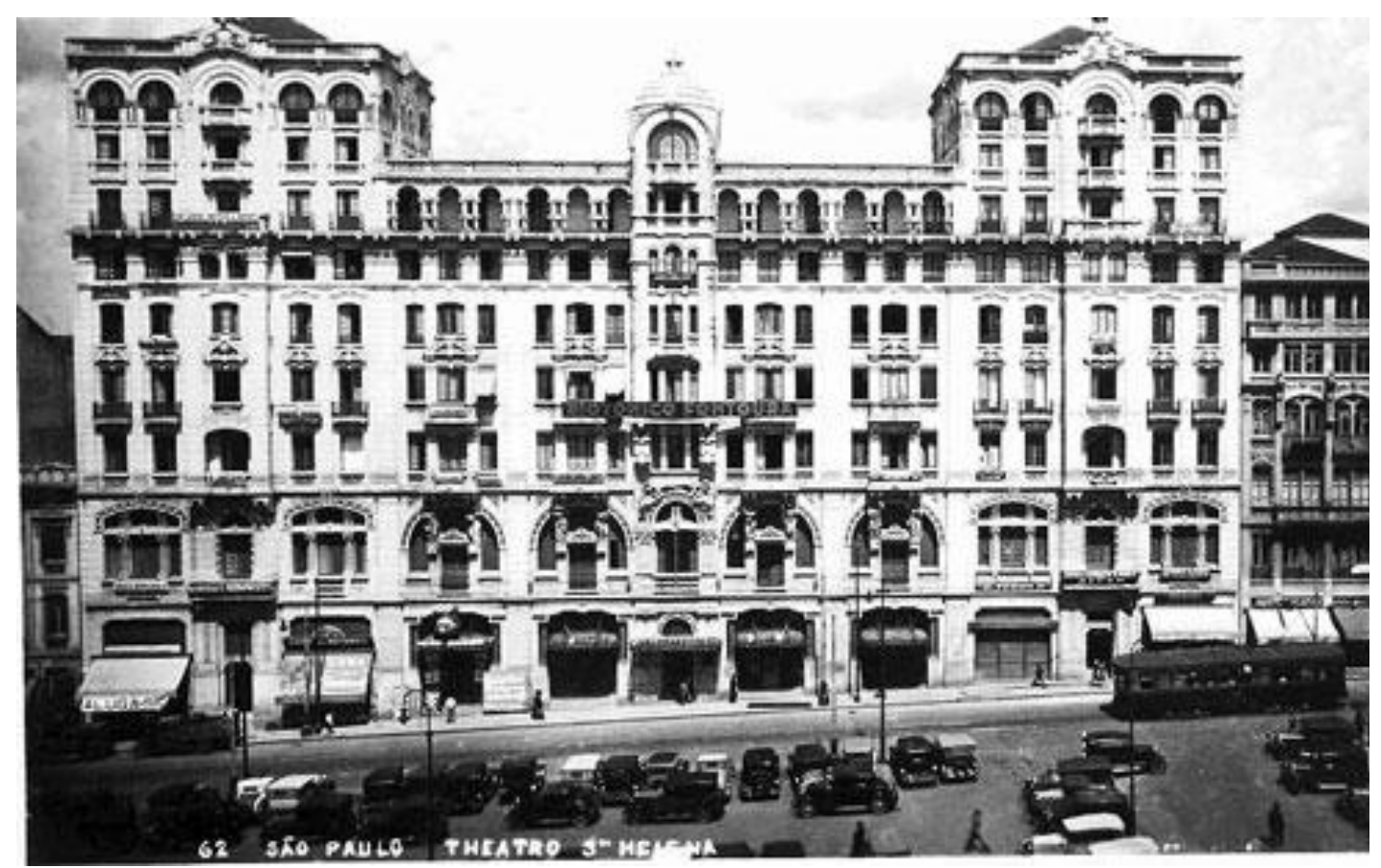

Figura 6 - Cartão Postal Wessel. Fotografia do antigo Palacete Santa Helena, demolido em 1971, quando da construção da estação do Metrô da Sé.

Estiveram presentes na reavaliação que o crítico fez de artistas como Rebolo Gonsales, Aldo Bonadei, Manoel Martins e Alfredo Volpi, aspectos como a preocupação com os danos à natureza decorrentes do desenvolvimentismo tecnológico. No horizonte dos anos de 1970, Schenberg observou, ainda, que a compreensão da contribuição e das possibilidades abertas por esses artistas poderia ser melhor avaliada com a superação da "visão intelectualista, como a que predominou até há pouco tempo nos meios artísticos de vanguarda, mas que está basicamente superada",62.

Sua apreciação não apenas retomou as questões desses artistas de maneira retrospectiva, como também apresentou novas interpretações de seu significado, apontando o campo de possibilidades aberto por artistas do Grupo Santa Helena. Desde a década de 1960, quando constatou o desinteresse dos artistas pela pintura, Mario Schenberg afirmava que suas possibilidades não estavam esgotadas ${ }^{63}$, apesar de ser essa uma opinião pouco comum à época.

Nos últimos anos da década de 1970, a reavaliação da obra dos artistas desse grupo teria indicado novos rumos a serem explorados: "a pintura à óleo dos artistas do Grupo Santa Helena, especialmente a de Bonadei, Volpi e Rebolo, torna-se uma inspiração para a arte de amanhã’64.

\footnotetext{
${ }^{62}$ SCHENBERG, Mario. Pensando a Arte, São Paulo: Nova Stella, 1988, p. 84.

63 "[...] desejo manifestar minha convicção de que as possibilidades das formas tradicionais de expressão artística, como a pintura, a escultura e o desenho e a gravura, não estão esgotadas, como se diz frequentemente. Sofrerão, sem dúvida, transformações e se beneficiarão de novos materiais" (SCHENBERG, Mario. Pensando a Arte, São Paulo: Nova Stella, 1988, p. 205).

${ }^{64}$ SCHENBERG, Mario. Pensando a Arte, São Paulo: Nova Stella, 1988, p. 129.
} 
Na década de 1960, Mario Schenberg havia percebido uma convergência entre algumas tendências do Novo Realismo e a arte do Oriente, especialmente aquela influenciada pelo Zen, na medida em que ambas apreciavam elementos como a simplicidade, a pobreza artesanal e os objetos envelhecidos pelo uso ${ }^{65}$. Essa proximidade, contudo, não se dava com relação ao amor pela Natureza talvez pelo fato de o "Zen ter se desenvolvido numa civilização agrária, ao passo que o novo realismo é produto de uma sociedade industrial" ${ }^{106}$.

Nos anos de 1970, por outro lado, a relação entre arte e natureza tornou-se bastante significativa no horizonte crítico de Schenberg, aliada à preocupação com a preservação dos recursos naturais. Surgiram considerações sobre Arte Catastrófica e Arte Ecológica, enquanto tendências identificadas pelo crítico naquele momento, preocupadas com a poluição e seus prejuízos, colocandose como advertência a respeito do perigo da deterioração da natureza e da utilização da energia nuclear.

Essa advertência foi vista por Schenberg ${ }^{67}$ como uma tentativa de conscientização em relação a

uma das causas mais apaixonantes de nossos dias: a defesa do nosso ambiente e das nossas belezas naturais contra o vandalismo dos apetites econômicos desencadeados pelo tipo de desenvolvimentismo sem sentido e sem conteúdo humano que em má hora foi instalado em terras brasileiras.

Para o Professor Schenberg, o desenvolvimento tecnológico e industrial não poderia ser justificativa para a degradação dos recursos naturais do planeta e era preciso difundir no país o posicionamento de uma consciência mais atenta às demandas contemporâneas, que já estaria repudiando tal atitude em países cujo desenvolvimento tecnológico encontrava-se mais avançado ${ }^{68}$.

Por isso, tendências Catastrófica e Ecológica eram extremamente significativas, pois refletiam o sentimento nascente de responsabilidade moral do ser humano diante do prenúncio da ameaça proveniente de um modelo de desenvolvimento tecnológico apoiado numa visão positivista. Mario Schenberg, ao comentar as obras de Helena Armond, em 1979, enfatizou que seu trabalho, assim como "outros tipos de arte catastrófica e de arte ecológica, representa o despertar de um senso profundo de responsabilidade moral e de amor pela humanidade, que caracterizará todas as obras de artísticas realmente significativas do futuro imediato" ${ }^{\circ 9}$.

Tornou-se, mais uma vez, imprescindível compreender que o sentido de Natureza e de dignidade humana presentes no humanismo pós-renascentista havia deixado de ser suficiente para as demandas do século XX. Fazia-se necessário ampliar a dimensão dessas duas noções.

\footnotetext{
${ }^{65}$ SCHENBERG, Mario. Pensando a Arte, São Paulo: Nova Stella, 1988, p. 186.

${ }^{66}$ SCHENBERG, Mario. Pensando a Arte, São Paulo: Nova Stella, 1988, p. 186.

${ }^{67}$ SCHENBERG, Mario. Pensando a Arte, São Paulo: Nova Stella, 1988, p. 139.

${ }^{68}$ SCHENBERG, Mario. Pensando a Arte, São Paulo: Nova Stella, 1988.

${ }^{69}$ SCHENBERG, Mario. Pensando a Arte, São Paulo: Nova Stella, 1988, p. 138.
} 
A emergência de motivações como essas foi significativa, na medida em que Mario Schenberg, guiado por sua própria intuição e confiando na dos artistas, considerava a arte como um indicador das grandes questões com as quais o ser humano se debatia em seu tempo histórico. Em texto sobre o artista Rebolo Gonsales, de $1973^{70}$, o crítico refletiu acerca da função da arte e da necessidade premente de reencontrar a natureza:

A arte tem uma importância prospectiva fundamental. Ela nos ajuda a descobrir o que começa a ser de necessidade premente para a humanidade, em cada etapa nova de sua evolução. Hoje, temos necessidade de uma nova aproximação com a Natureza, da qual viemos nos afastando há séculos. O ciclo racionalista e tecnologista, iniciado durante a Renascença, chegou ao seu fim com a sociedade de consumo, na sua mortífera robotização e poluição. É questão de sobrevivência, não meramente de estética, o reencontro do Homem com a Natureza.

Assim como o posicionamento político e a relação entre arte e tecnologia estiveram presentes na pauta da década anterior, a preocupação ecológica despertou a atenção dos artistas sobre os quais Schenberg escreveu nos anos de 1970, como demonstrou a constante reflexão a respeito das tendências ligadas ao tema em suas críticas do período.

Foi perceptível, ainda, nas reflexões de Schenberg $^{71}$ a respeito dos rumos da arte contemporânea a partir de então, a tentativa do crítico de compreender a perplexidade diante do esvaziamento dos movimentos da década de 1960:

ela [a arte de Sérgio Lima] adquire uma importância maior pela sugestão de novos caminhos, no momento em que reina uma grande perplexidade na arte brasileira, e também na arte mundial, decorrente do esvaziamento dos vários movimentos que dominaram o panorama da última década.

As características desse novo momento da arte eram diferentes, pois já não era possível sentir o caráter contestatório o conceito de vanguarda perdeu sentido ${ }^{72}$, e as influências internacionais já não seriam tão fortes "permitindo a cada artista manifestar mais livremente as suas tendências pessoais, assim como a manifestação mais espontânea das tendências não só nacionais mas mesmo regionais" "73. Em texto crítico sobre Ivald Granato, Schenberg afirmou que ambos chegaram à conclusão de que só seriam viáveis as formas individuais de criação ${ }^{74}$.

\footnotetext{
${ }^{70}$ SCHENBERG, Mario. Pensando a Arte, São Paulo: Nova Stella, 1988, p. 84.

${ }^{71}$ SCHENBERG, Mario. Pensando a Arte, São Paulo: Nova Stella, 1988, p. 109.

${ }^{72}$ SCHENBERG, Mario. Pensando a Arte, São Paulo: Nova Stella, 1988.

${ }^{73}$ SCHENBERG, Mario. Pensando a Arte, São Paulo: Nova Stella, 1988, p. 142.

${ }^{74}$ SCHENBERG, Mario. Pensando a Arte, São Paulo: Nova Stella, 1988.
} 


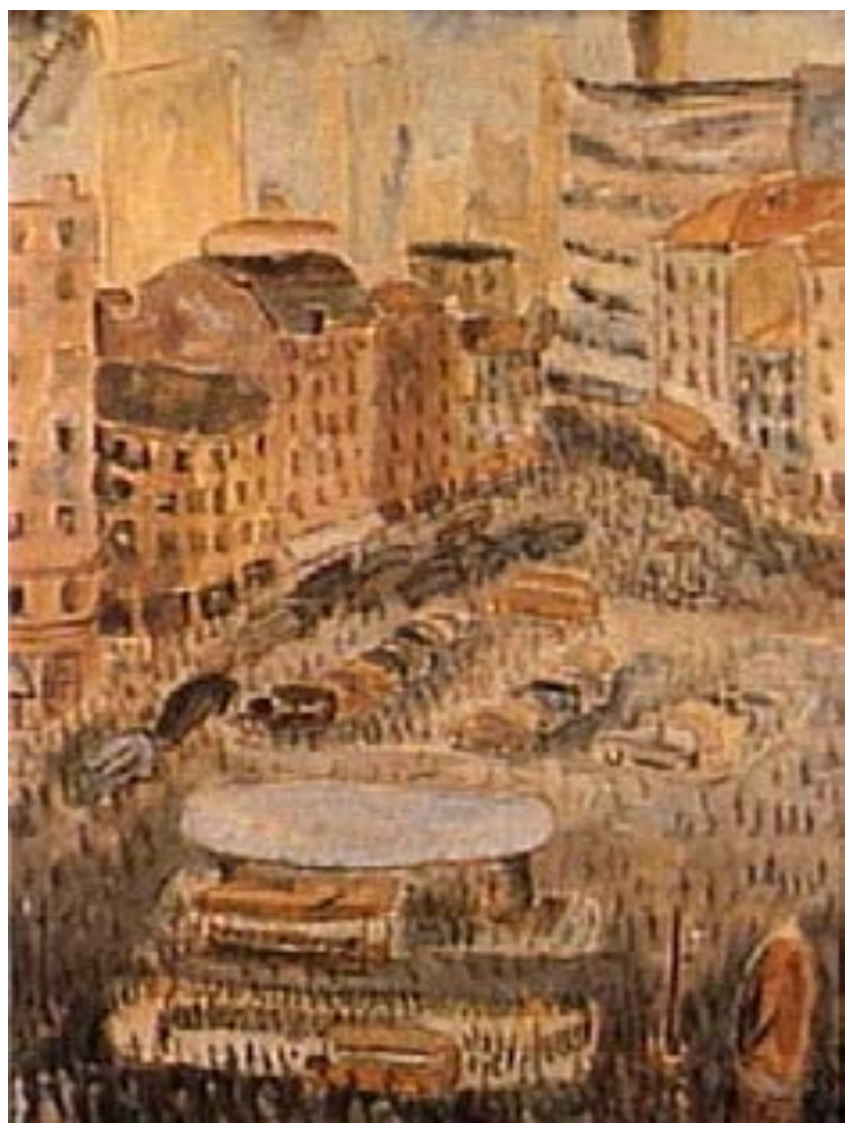

Figura 7 -Manuel Martins, Praça da Sé, ca. 1940. Óleo sobre madeira, c.s.e., 50 × $40 \mathrm{~cm}$. Reprodução fotográfica Gerson Zanini. 


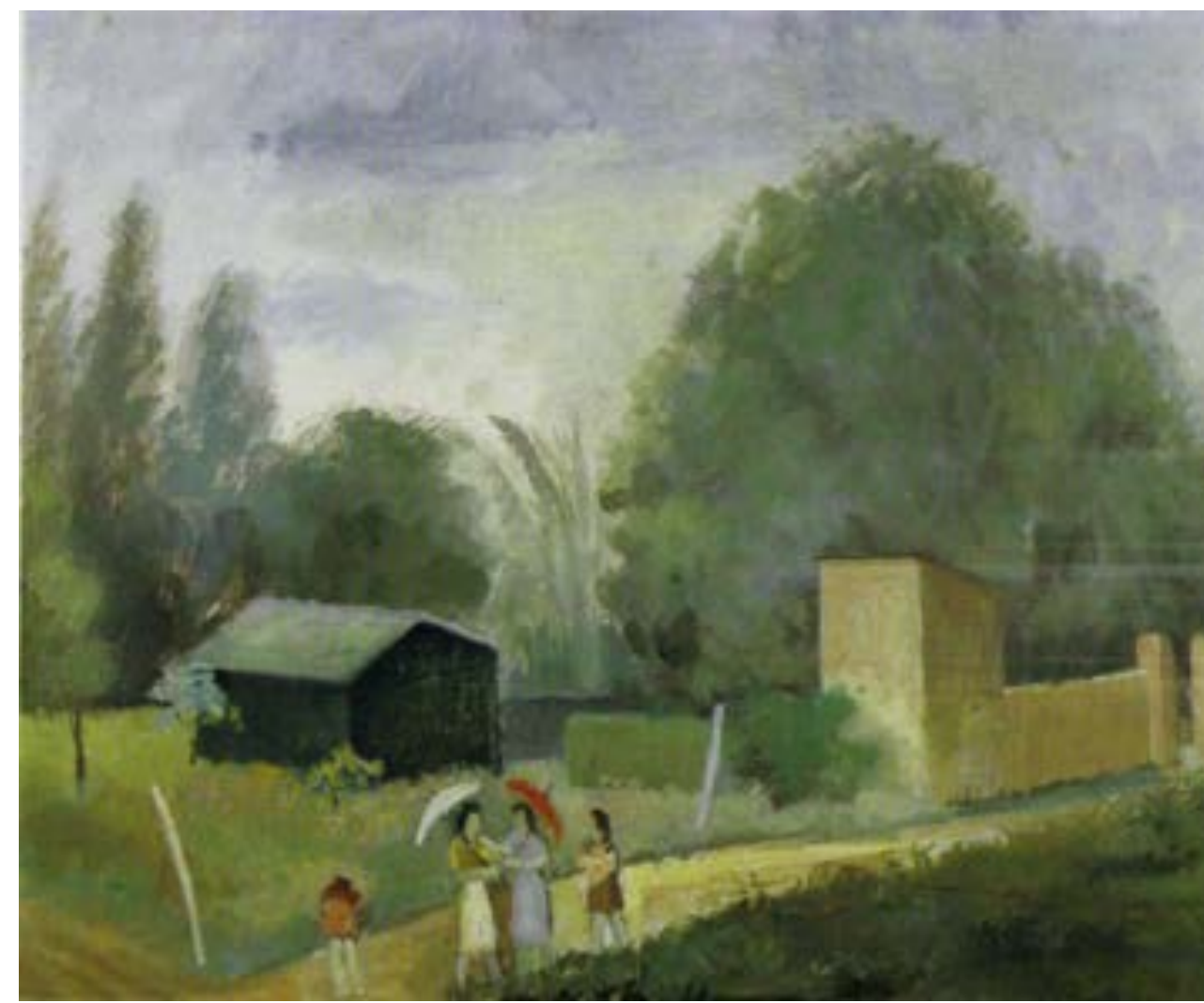

Figura 9 - Francisco Rebolo Gonsales. Paisagem com Figuras, 1942. Coleção MAC USP.

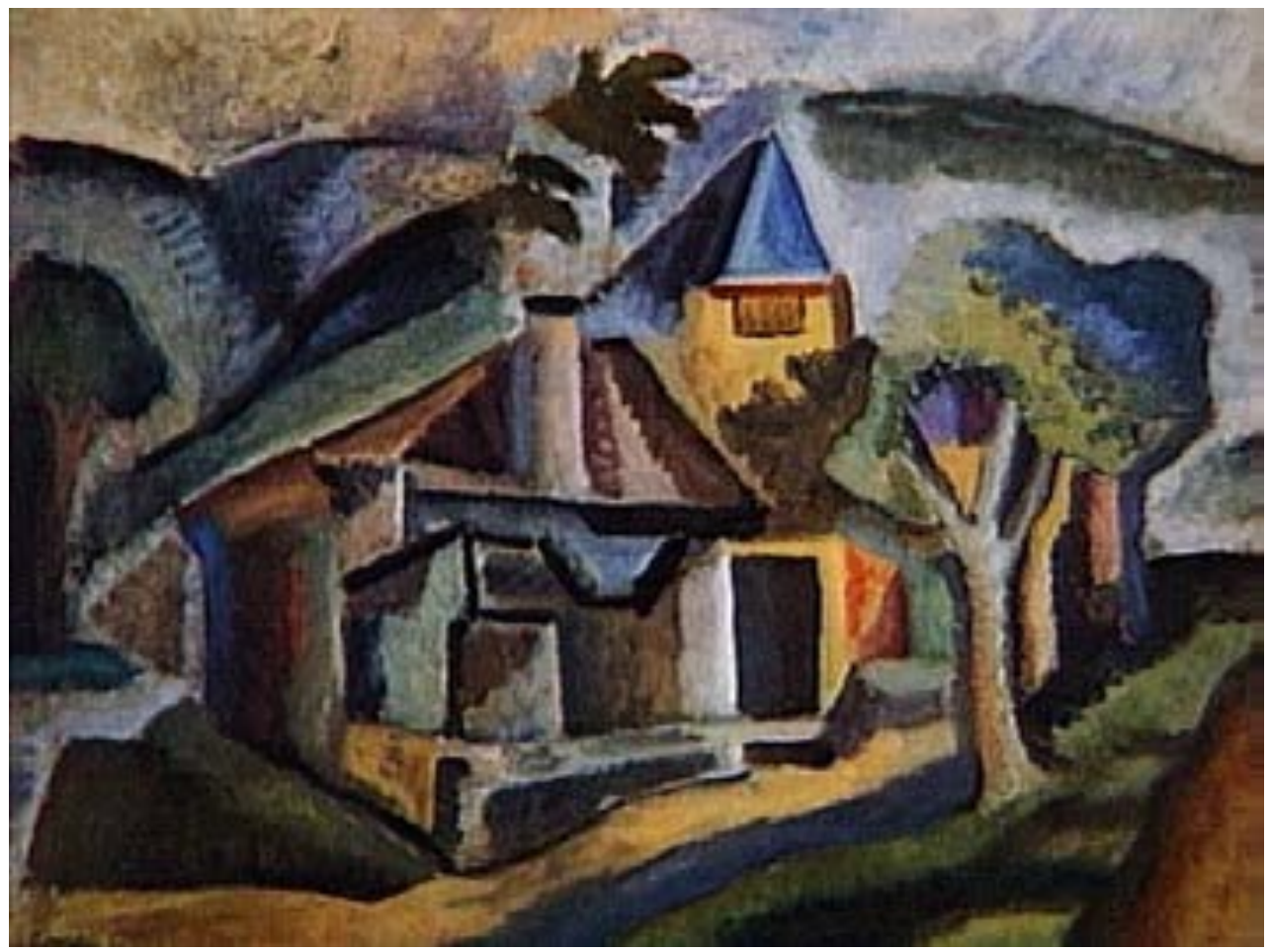

Figura 8 - Aldo Bonadei, Paisagem, 1946. Óleo sobre tela, 50 x $63 \mathrm{~cm}$. Reprodução fotográfica Romulo Fialdini 


\section{Mira Schendel}

Mira Schendel (Zurique, Suíça 1919 - São Paulo/SP 1988) trabalhou com um elemento que não participava apenas do projeto crítico de Mario Schenberg, mas também de sua visão de mundo: o contato com a Arte e o Pensamento do Oriente. Para o crítico, a obra de Mira Schendel operava uma síntese entre Ocidente e Oriente ${ }^{75}$.

Ao observar na obra da artista elementos como a força da gestualidade no traço grafado, a organização espacial dos planos e sua materialidade, fossem eles constituídos por massas de cores ou por poucos traços em fundo branco, Mario Schenberg mobilizava elementos da estética chinesa. Por isso, será feita uma análise de alguns aspectos da estética oriental tomando-se como ponto de partida a reflexão de Mario Schenberg sobre o trabalho de Mira Schendel, a fim de aprofundar considerações feitas anteriormente a respeito da ponte realizada pelo crítico entre o Oriente e o Ocidente.

Conforme já foi enfatizado anteriormente, essa ponte foi um aspecto metodológico da visão de mundo do crítico que esteve presente em toda a crítica de arte de Schenberg. Esse referencial em comum com Mira Schendel terá destaque em todo o período em que o crítico refletiu acerca do trabalho da artista.

Mira Schendel fixou residência no Brasil em 1949 e, em 1953, mudou-se para São Paulo ${ }^{76}$. O crítico de arte acompanhou os desdobramentos do trabalho da artista com bastante atenção entre as décadas de 1960 a 1988, quando a artista faleceu. Segundo Schenberg, "no começo dos anos sessenta, Mira abriu-se para a arte e filosofia da cultura chinesa" ${ }^{77}$. Nesse período, Mira Schendel realizou trabalhos em papel de arroz conhecidos como Monotipias, a respeito das quais o crítico escreveu, em 1964, o texto Monotipias de Mira Schendel ${ }^{78}$, no qual apontou os elementos destacados anteriormente.

\footnotetext{
${ }^{75}$ SCHENBERG, Mario. Pensando a Arte, São Paulo: Nova Stella, 1988. Mira Schendel também tinha em seu horizonte referenciais filosóficos, aos quais Mario Schenberg também esteve atento em seus textos críticos. Neste estudo, contudo, serão feitos apenas alguns comentários em relação ao pensamento estético do Oriente, especificamente o chinês. Existe um estudo a respeito da relação da artista com a Filosofia: ALVES, Cauê. A dimensão filosófica do trabalho de Mira Schendel. Universidade de São Paulo: São Paulo, 2012 (tese de doutorado).

${ }^{76}$ Para mais dados biográficos, veja-se o Anexo $C$ deste volume.

${ }^{77}$ SCHENBERG, Mario. Paisagens de Mira Schendel. Arquivo do Centro Mario Schenberg de Documentação da Pesquisa em Arte - ECA/USP. Texto datado de 1979.

${ }^{78}$ SCHENBERG, Mario. Pensando a Arte, São Paulo: Nova Stella, 1988.
} 


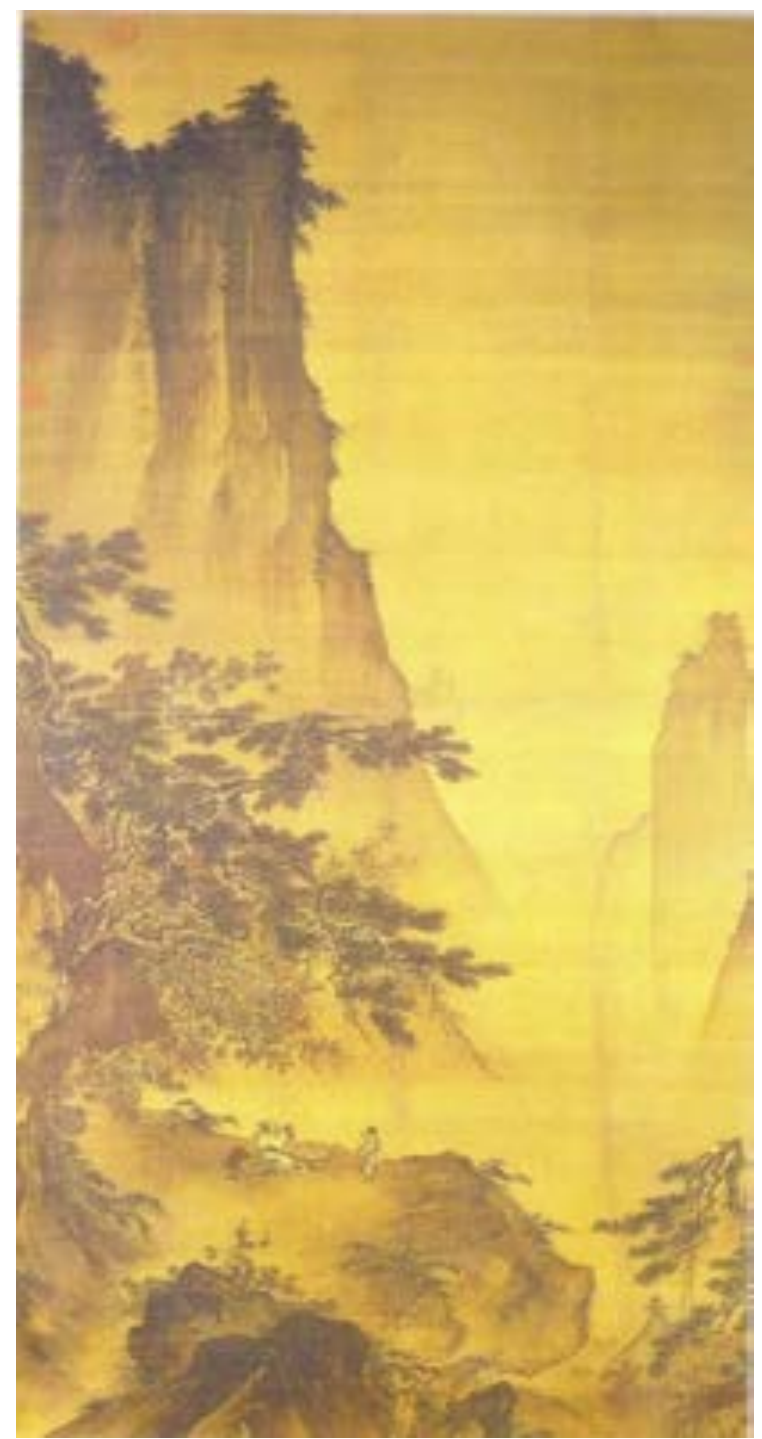

Figura 10 - Ma Yüan, Paisagem ao luar, c. 1200. Rolo suspenso, pintura em seda, 149,7 x 78,2 cm. Museu do Palácio Nacional, Taipé.
O pensamento e a arte do oriente permearam a cosmovisão do crítico não somente com relação à arte, mas também à política e à história da ciência; oferecendo, muitas vezes, alternativas à dinâmica de um racionalismo tecnicista, herdeiro do positivismo e do iluminismo do século XVIII.

Para René Huygue ${ }^{79}$, enquanto a arte ocidental tende a uma exploração do formal e do material, buscando desenvolver-se por meios intelectuais, considerados mais seguros e controláveis, dos quais decorre sua grande atração pelo realismo; a arte oriental é baseada no pensamento indiano e no chinês, que determinaram cedo suas estéticas em relação ao ocidente. Para a arte oriental, a vida interior é repleta de tendências e latências prontas para emergir. Realizar essas tendências, tornando-as conscientes, significa dar forma física a elas no mundo, tornando-as visíveis à sensação e ao pensamento de outros indivíduos. Uma vez colocada em imagem, ela fica à espera do espectador que a reconstituirá em seu estado de $\operatorname{alma}^{80}$.

Existe uma profunda relação entre caligrafia e pintura na arte chinesa: ambas têm origem no traço, elemento básico do registro grafado. Nos dois casos, busca-se expressar o $C h^{\prime} i$, isto é, vitalidade rítmica ${ }^{81}$. Cada linha traçada é apreciada na medida em que expressa um ritmo vital: "A sensibilidade chinesa está constituída para perceber os traços: a beleza é vista na força, vida e delicadeza dos traços" ${ }^{\prime 82}$. Caligrafia e pintura exigem habilidade e planejamento antes de serem executadas pois, uma vez feito o traço à tinta, não é possível fazer correções. A importância da gestualidade está presente. O sentido de beleza está no traço e no gesto.

$\mathrm{O}$ artista deve deixar que a própria natureza expresse sua criatividade em sua obra, o que requer estudo. O pintor deve conhecer a natureza, os animais, as flores, etc. Mas quando executar sua pintura, não deve reproduzir simplesmente tais objetos. Há uma preparação para pintar que envolve a

\footnotetext{
${ }^{79}$ HUYGHE, René. Dialogue avec le visible. Paris: Flammarion, 1955.

${ }^{80}$ HUYGHE, René. Dialogue avec le visible. Paris: Flammarion, 1955.

${ }^{81}$ SUN CHIA CHIN. Poesia e Pintura Chinesa. Revista China em Estudo, ano 1, $\mathrm{n}^{\circ}$ 1, 1994, p. 84.

${ }^{82}$ SUN CHIA CHIN. Poesia e Pintura Chinesa. Revista China em Estudo, ano 1, no 1, 1994, p. 84.
} 
meditação, com a finalidade de atingir o estado contemplativo desejado. Nesse sentido, a arte chinesa está em profunda relação com o pensamento oriental: budismo, taoísmo e confucionismo ${ }^{83}$.

Ernest Gombrich ${ }^{84}$ afirma que dificilmente um pintor chinês se colocaria diante de uma paisagem para pintá-la. Ele deve pintar o estado de espírito que uma paisagem origina. O estudo contínuo visava adquirir tal habilidade, que permitisse ao pintor executar sua obra antes que a inspiração se dissipasse ${ }^{85}$.

$\mathrm{Na}$ arte chinesa, a obra de arte é vista como meio pelo qual o espectador pode acessar, por via da contemplação, o mesmo estado de espírito do artista quando executou a pintura, ao momento de sua inspiração. É preciso, desse modo, que tanto o artista quanto espectador se proponham a um estado meditativo e reflexivo.

Voltando às monotipias de Mira Schendel, em 1964, Schenberg afirma que em alguns desses trabalhos, ela "conseguiu se aproximar do espírito das paisagens Song, de maneira pessoal sua, redescobrindo ritmos de uma espacio-temporalidade cósmica quase inacessíveis aos artistas ocidentais. Visão reveladora de um encontro unitivo do homem com o universo" ${ }^{\text {" }}$.

O crítico compara, a seu modo, o que foi pontuado a respeito do sentido do traço e do ritmo que este é capaz de expressar, remetendo à dimensão da espacialidade e da temporalidade plasmadas nas monotipias. O grafismo surge, também aqui, ligado tanto ao traço enquanto desenho, como às letras e palavras que aparecem vez por outra nas monotipias. Mais adiante, o crítico comenta, a respeito disso:

\begin{abstract}
Mira utilizou vários tipos de linha em suas monotipias, cada um soberbamente adequado para exprimir uma intuição diferente. Numa das séries predomina um traço grosso, semelhante a um pincel caligráfico chinês, por vezes associado a um traço mais fino que o continua ou que com ele se entrelaça em contraponto rítmico ou estrutural. [...] Uma caligrafia surpreendente pela concisão e eficácia comunicativa. Com um traço sensivelmente retilíneo, de poucos centímetros, reduzindo-se a um toque de mancha negra, consegue contato quase direto com espectador, provocando uma ressonância interior e sutilíssima" ${ }^{87}$.
\end{abstract}

\footnotetext{
${ }^{83}$ Budismo ch'an: conhecido como budismo do Grande Veículo. Aquele que por seus méritos está pronto para entrar no Nirvana (quer dizer, a extinção da individualidade) é objeto de particular veneração quando retarda sua entrada para salvar outros seres. O Confucionismo "clássico", que foi muito influente, pregava a "harmonia entre o Homem e a Ordem Universal, que devia ser adquirida mediante a pontual e cuidadosa observância dos ritos e normas de conduta. Os seres vivos, assim como os inanimados, fazem parte de uma Ordem Universal. O homem não é a medida do universo, ele deve adequar-se a essa ordem." (BRODRICK, Alan Houghton. La pintura china. México Fondo de Cultura Económica, 1954, p.13). Taoísmo: Tao significa caminho, um modo de viver e de ver o Universo e influir sobre ele. O Homem deveria descobrir a Ordem Universal em si mesmo, uma vez livre de desejos e ilusões. Um de seus princípios era a harmonia do homem com a Ordem Universal, com as "leis do universo". (Idem, Ibidem, p.13).

${ }^{84}$ GOMBRICH, Ernest. História da Arte. Rio de Janeiro: LTC, 2009, p. 153.

${ }^{85}$ GOMBRICH, Ernest. História da Arte. Rio de Janeiro: LTC, 2009, p. 153.

${ }^{86}$ SCHENBERG, Mario. Pensando a Arte, São Paulo: Nova Stella, 1988, p. 22.

${ }^{87}$ SCHENBERG, Mario. Pensando a Arte, São Paulo: Nova Stella, 1988, p. 22.
} 


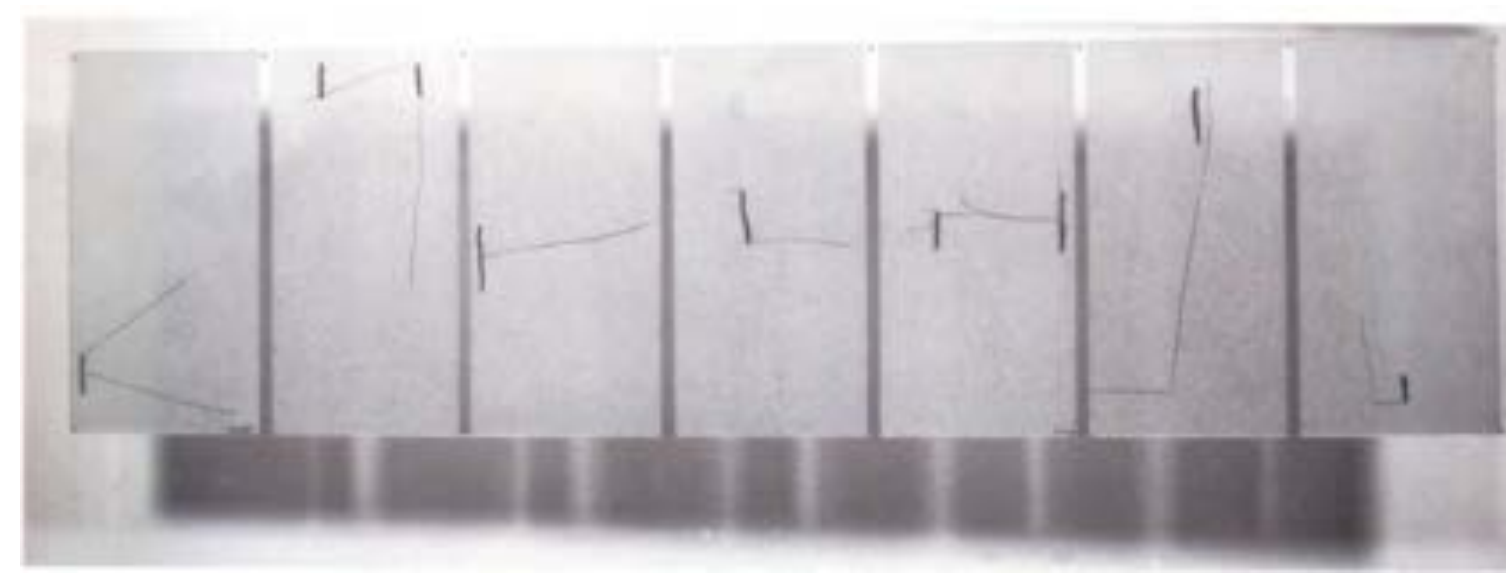

Figura 11 - Mira Schendel. Monotipias. Óleo sobre papel de arroz, 1965, 46 x $172 \mathrm{~cm}$.

Cada traço aparece à apreciação do crítico como um horizonte de significados na expressão de ritmos diferenciados e consegue, com grande simplicidade e concisão, alcançar o espectador sensível à dimensão comunicativa dos traços distribuídos no papel de arroz. É interessante observar que Schenberg opera seu movimento crítico a partir do referencial em comum com a artista. Nesse sentido, o processo de ressonância interior estaria fundamentado na possibilidade de comunicação que oferece, porquanto a contemplação da obra de arte permite ao espectador acessar o estado de espírito do artista ao executá-la.

Nesse ponto, enfatiza-se também a noção da arte como processo de ressonância entre artista e observador identificada na obra de Mira que, para Mario Schenberg, opera uma síntese entre Ocidente e Oriente numa expressividade própria da Arte Contemporânea ${ }^{88}$.

Com a intenção de tornar a pesquisa estética que envolve as monotipias de Mira Schendel mais acessível ao público, o crítico expôs alguns de seus referenciais a fim de proporcionar ao leitor instrumental teórico e balizas mais precisas para a apreciação e compreensão da obra.

\footnotetext{
${ }^{88}$ SCHENBERG, Mario. Paisagens de Mira Schendel. Arquivo do Centro Mario Schenberg de Documentação
} da Pesquisa em Arte - ECA/USP. Texto datado de 1979. 


\section{UN RKEN DE TEMPS ET}
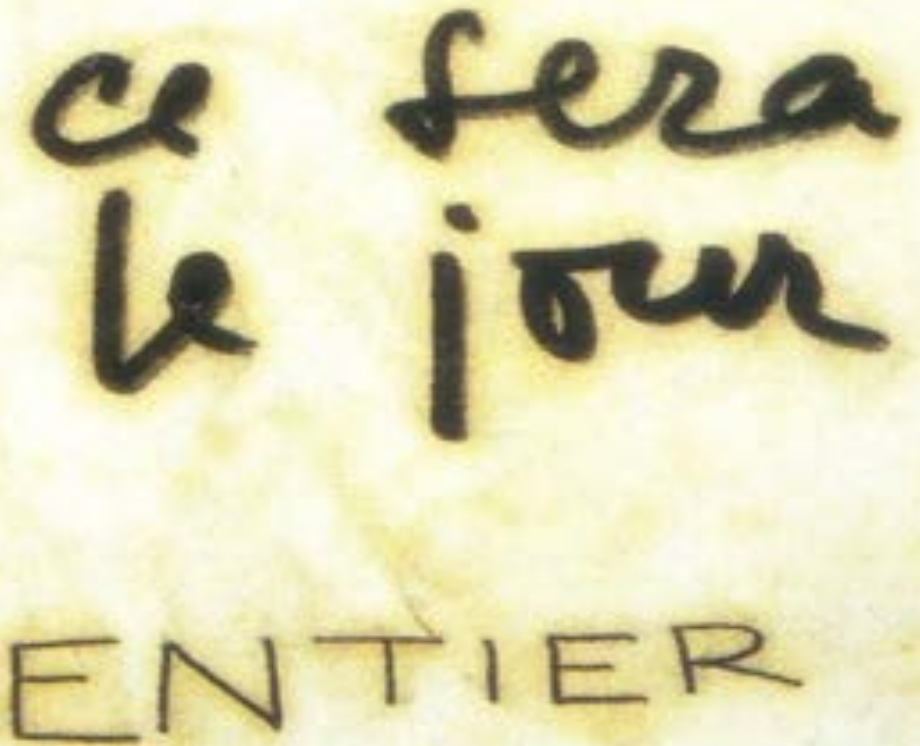

Figura 12 - Mira Schendel, Sem título, 1964-65. Monotipia (óleo sobre papel de arroz), $46 \times 23 \mathrm{~cm}$. 


\title{
Schenberg: crítica como incentivo ${ }^{89}$
}

Num período em que a autonomia da obra de arte e muitos outros paradigmas foram contestados, Mario Schenberg parece ter se dado conta de que o incentivo, o diálogo e a mediação seriam mais produtivos e apropriados ao exercício crítico que o julgamento das qualidades formais da obra de arte. Fundamentado na análise de seus escritos desse período, bem como nos depoimentos de diversos artistas que conviveram com o crítico, foi possível constatar que sua postura frente aos artistas e à reflexão estética se colocava não como avaliação, mas como incentivo.

A proximidade com os artistas que, nas décadas de 1960 e 1970, tomaram rumos diversificados e trabalharam em novas propostas, além de sua participação nas exposições e debates que marcaram o período, permitiu a Mario Schenberg manter um contato direto com o ambiente das Vanguardas Brasileiras. Desse modo, o crítico conseguiu perceber varias tendências, suas relações e os conceitos em jogo na arte brasileira de então. $\mathrm{O}$ artista Maurício Nogueira Lima ${ }^{90}$ ajudou a traçar um quadro da postura do crítico em relação aos grupos de artistas:

\begin{abstract}
Nessa época, a principal característica de Schenberg, foi a de apoiar os grupos de vanguarda que tentavam subverter a arte brasileira; principalmente na década de 60 , quando eu e o Schenberg mais colaboramos com esses grupos. [...] Mário nos deu um grande apoio, escrevendo vários artigos [...]. Os artigos eram publicados em catálogos de exposições e, às vezes, uma ou outra revista cedia espaço para ele expor o seu pensamento. Entretanto, Mário sempre 'sacava' as características de cada artista e, muitas vezes, descobria valores que o próprio artista, no seu ato de pintar, não conhecia.
\end{abstract}

Em relação à vivência de Mario Schenberg junto aos artistas, é importante destacar o contato pessoal estabelecido pelo crítico com os artistas, seja escrevendo sobre eles, seja em longas conversas. A artista Amélia Toledo ${ }^{91}$, por exemplo, relatou a profunda compreensão que o crítico chegava a ter dos artistas nos contatos pessoais que criava e gostava de cultivar:

O Mário foi fazer uma visita ao meu atelier por volta de 64. Nesse período ele estava sendo procurado pela polícia, mas estava querendo visitar o atelier dos artistas para manter vivo o interesse deles. [...] Talvez, nesses contatos pessoais, ele fosse muito

\footnotetext{
${ }^{89}$ Uma versão concisa desse item foi publicada em: PISMEL, Ana Paula Cattai. Schenberg e vanguardas: Crítica como parceria. In: VIII Congresso de Estética e História da Arte, Desenhos da Pesquisa: Novas Metodologias da Pesquisa em Arte. São Paulo: Museu de Arte Contemporânea da Universidade de São Paulo, 2012. v.1. p. $279-288$.

${ }^{90}$ LIMA, Maurício Nogueira. Mário Schenberg: incentivador e crítico. In AJZENBERG, Elza (org.). Schenberg - Arte e Ciência. São Paulo, 1995, p. 42.

${ }^{91}$ TOLEDO, Amélia. Amélia Toledo. In AJZENBERG, Elza. In Shenberg: Arte e Ciência. São Paulo: ECA/USP, 1997, p. 36-7.
} 
mais fundo ainda do que nos escritos, porque era incrível como percebia a intimidade de cada um.

O contato pessoal com os artistas e a ausência de pressupostos foram características importantes da crítica de arte de Mario Schenberg, o que poderia explicar porque o crítico foi tão bem quisto por aqueles com os quais conviveu, não somente nas décadas de 1960 e 1970, mas durante todo o período em que atuou no meio artístico.

O incentivo aos artistas, por vezes, ia além do convívio e dos textos críticos que produzia. Quando necessário, Mario Schenberg os auxiliava com material (tintas, telas, etc.) e, muitas vezes, comprava obras para ajudá-los ${ }^{92}$. Além disso, recebia-as de presente, em agradecimento às críticas que escrevia.

Pôde-se perceber que o prestígio do Professor Schenberg como cientista de renome internacional contribuiu para sedimentar a credibilidade de sua crítica de arte, na medida em que sua posição acadêmica inspirava respeito. Escrevendo sobre os artistas que incentivava, o crítico utilizava sua posição social e intelectual para dar visibilidade ao trabalho deles.

A relevância dessa atitude por parte do crítico mostrou-se relevante em relação a uma das características marcantes da arte de vanguarda desse momento, que foi a emergência de vários artistas jovens que traziam renovação à arte brasileira, tendo sido responsáveis por uma grande diversidade de tendências identificadas por Schenberg. Sem dúvida, isso não escapou à visão do crítico, que estava atento à importância de se incentivar e apoiar esses artistas, que estavam iniciando sua carreira.

92 “Schenberg, com o dinheiro de professor, - que na época valia mais do que hoje - ajudava os artistas a comprar telas, tinta e material, tornando-se dessa forma um grande colecionador, sempre com um acervo muito bom e muito rico." (GOLDFARB. José Luiz Goldfarb. In AJZENBERG, Elza. In Shenberg: Arte e Ciência. São Paulo: ECA/USP, 1997, p.45. 


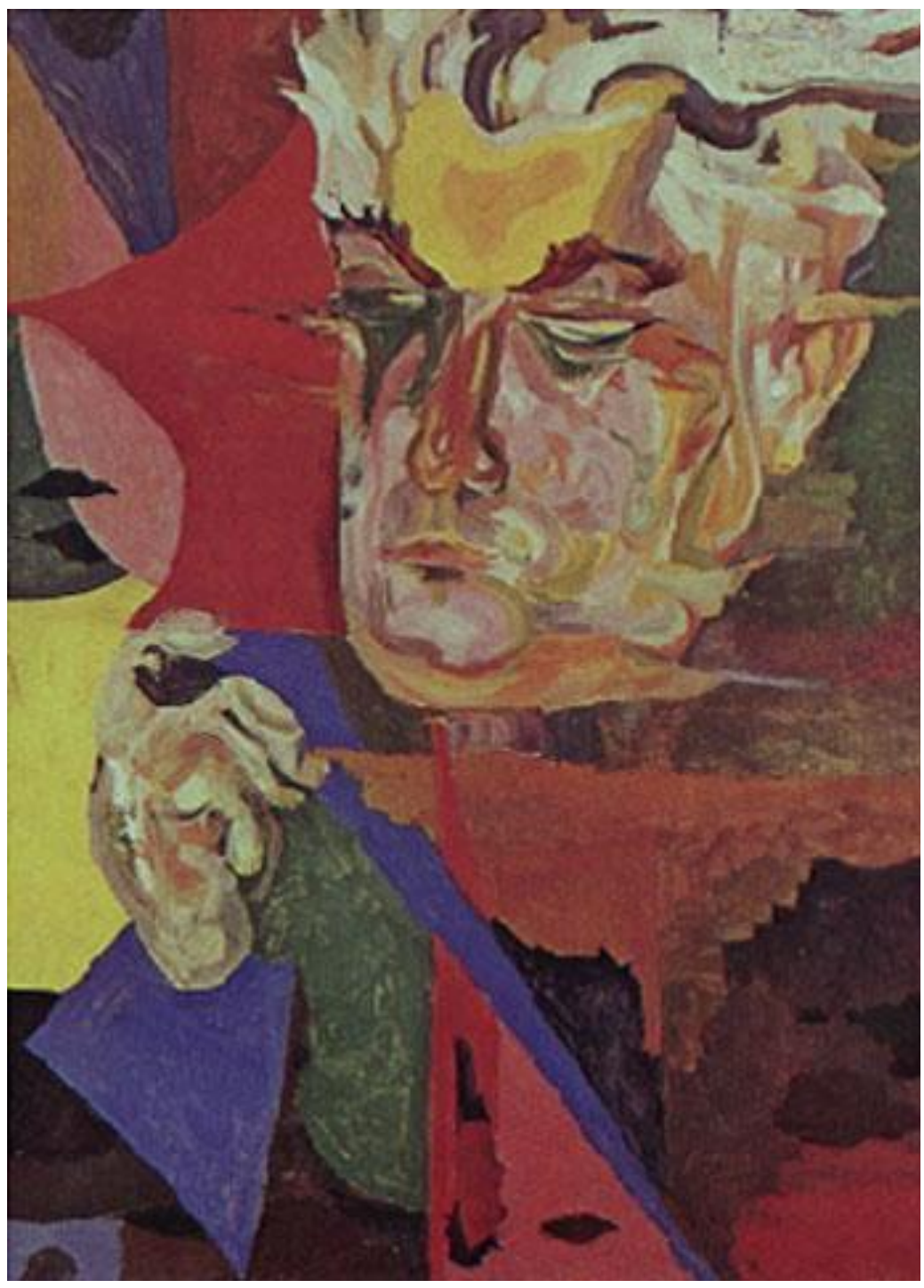

Figura 13 - Flávio de Carvalho, Retrato de Mário Schemberg, 1968, óleo sobre tela, c.s.d., 98 x $67 \mathrm{~cm}$. Coleção Particular. 
Para Mario Schenberg, era preciso ter coragem e desapego aos valores do passado e apostar na renovação daquilo que se encontrava estabelecido, fosse no campo da política; fosse no da cultura ou das artes. Os jovens estariam menos presos ao passado e, portanto, mais abertos ao presente e ao futuro, tendo sensibilidade privilegiada para perceber os valores em gestação. Entretanto, o crítico reconhece que essa não era uma característica exclusiva dos indivíduos jovens. Por esse motivo, Schenberg afirmava que os "desbravadores são os jovens de espirito" 93 .

Conforme já foi apontado, as Vanguardas Brasileiras tiveram uma preocupação acentuada em relação às transformações sofridas na ambientação política, econômica e social do país. Por um lado, ressentiam-se da censura e da arbitrariedade do regime militar; por outro, esperavam que a denúncia impregnada em sua produção artística fosse capaz de transmitir seu posicionamento contra a situação do país. No movimento dialético da análise de Mario Schenberg, a arte evidenciava valores e crises da época na qual era produzida, assim como tendências futuras ainda pouco claras ao senso comum.

Mario Schenberg foi, antes de tudo, um amante da arte e incentivador de artistas e movimentos com propostas inovadoras, tendo sido essa uma característica marcante de seu projeto crítico $^{94}$. Desde os anos de 1950, apoiou os movimentos de vanguarda que tinham por objetivo dar novos rumos à arte brasileira ${ }^{95}$, tivessem eles raízes nas vanguardas construtivas (Concretismo, Neoconcretismo, por exemplo) ou dadaístas (Novo Realismo, Realismo Mágico, Fantástico, entre outros).

Esse traço de sua postura the rendeu objeções da parte de outros críticos: sua avaliação era vista como parcial, sem critérios objetivos e não seria seletiva em relação à qualidade do trabalho dos artistas que apoiava, pois Mario Schenberg "[distribuiria] elogios com incômoda facilidade, quase sempre errando em seu prognóstico" ${ }^{\circ 6}$.

A artista Eva Fernandes ${ }^{97}$, por outro lado, ofereceu uma perspectiva que compreendia melhor a intenção do crítico:

Havia - e provavelmente há - quem o julgasse "parcial" como crítico. Sem dúvida, era parcial, mas a sua parcialidade era muito larga, abrangia muito, não era dogmática e fixada numa corrente só. Professor que era - e penso que se compreendia como instigador, como propulsor de talentos - procurava encorajar, abrir perspectivas. Numa época em que era comum discutir Arte em termos de escolas e técnicas, analisando superfícies, planos estruturados dessa ou daquela maneira, [...] [Mario Schenberg] via a personalidade do artista como ponto nodal.

\footnotetext{
${ }^{93}$ SCHENBERG, Mario. Pensando a Arte, São Paulo: Nova Stella, 1988, p. 193 (grifo nosso).

${ }^{94}$ Cf. OLIVEIRA, Alecsandra Matias de. Schenberg: Crítica e Criação. São Paulo: EDUSP, 2011.

${ }^{95}$ LIMA, Maurício Nogueira. Mário Schenberg: incentivador e crítico. In AJZENBERG, Elza (org.). Schenberg - Arte e Ciência. São Paulo, 1995, p. 42.

${ }^{96}$ FILHO, Antônio Gonçalves. Schenberg Pensa a Arte. Folha de São Paulo, 19/03/1988, Livros, p. D - 4. Disponível em http://acervo.folha.com.br/fsp/1988/03/19/349//4147898 Acesso em 20/01/2012.

${ }^{97}$ FERNANDES. Eva. Mário: Crítico de Arte. In AJZENBERG, Elza. Schenberg: Arte e Ciência. São Paulo: ECA/USP, 1997, p. 83.
} 
Percebeu-se, ainda, que se muitos dos jovens artistas que Schenberg apoiou ao longo de sua trajetória foram vistos como promessas não realizadas, houve também acertos, como Alfredo Volpi, Waldomiro de Deus, Lygia Clark, Mira Schendel, entre outros. Ao longo deste estudo, foi possível enfatizar que Mario Schenberg não estava preocupado em apostar apenas em artistas cujo futuro fosse promissor, mas em incentivá-los - "instigá-los”, para utilizar as palavras de Amélia Toledo mostrando a eles os novos direcionamentos possíveis que percebia nos trabalhos sobre os quais refletira.

Nesse sentido, foi bastante esclarecedor o relato de Maurício Nogueira Lima ${ }^{98}$ sobre a resposta que recebeu de Schenberg ao perguntar por que o crítico elogiava todos os artistas sobre os quais escrevia:

Pois bem, quando vejo uma pessoa fazendo um trabalho que dificilmente será exposto, pois são poucos os salões para artistas jovens aparecerem; acho fabuloso, fantástico, um herói nacional [...]. Mesmo porque é uma grande atitude do artista em realizar um trabalho, pensar em formas e imagens, desenhar [...]. O artista faz seu trabalho sem pretensão nenhuma de ficar rico, [...] então tenho que escrever muito bem sobre eles.

Mesmo que esse aspecto de sua crítica de arte tenha sido objeto de controvérsia, enfatizou-se a seguinte opinião por parte dos artistas: a contribuição de Mario Schenberg, seu incentivo e também a troca de experiências proporcionada pelo contato com o crítico foram importantes e produtivas. Diante disso, foi evidenciado que a intenção do crítico não era julgar as obras, mas incentivar os artistas, jovens ou experientes, mostrando-lhes novas perspectivas a partir de seus trabalhos e dando-lhes possibilidade de crescimento.

Para Schenberg, buscar as motivações do artista era mais interessante e produtivo que a análise do mérito do conjunto de sua obra com base em critérios de valoração determinados a partir de uma estética teleológica. Por isso, sua atuação se deu na chave do incentivo ao artista. Enquanto crítico de arte e grande incentivador, Mario Schenberg forneceu alicerces para os novos artistas e suas propostas renovadoras. A reflexão estética do crítico se deu com grande abertura ao novo, aspecto que caracterizou, aliás, a postura do crítico em relação a todas as esferas de seu pensamento.

Diferente da Arte Moderna, na qual noção da autonomia da obra de arte estava na base do procedimento crítico como análise dos aspectos formais da obra mediante critérios estabelecidos,

[a]s transformações do estatuto do objeto da arte e a presença de novos materiais, aliados à importância da conceituação, à expansão do circuito da arte, redefiniram igualmente as relações dos artistas com esses agentes, bem como instauraram e redimensionaram as novas funções e modalidades de instituição ${ }^{99}$.

\footnotetext{
${ }^{98}$ LIMA, Maurício Nogueira. Mário Schenberg: incentivador e crítico. In AJZENBERG, Elza (org.). Schenberg - Arte e Ciência. São Paulo, 1995, p. 43.

${ }^{99}$ FERREIRA, Glória; COTRIM, Cecília (seleção e comentários). Escritos de artistas: anos 60/70. Tradução de Pedro Süssekind... et al. - 2. Ed. - Rio de Janeiro: Jorge Zahar Ed., 2009, p. 23.
} 
Diante dessas transformações, é possível constatar que a crítica como julgamento do mérito da execução técnica e formal das obras de arte não se mostrava mais adequada, na medida em que não atingia a motivação fundamental da concepção das Vanguardas Brasileiras que surgiam na década de 1960. A proposta e o conceito passaram a ser tão, ou mais, importantes que o objeto no qual se encontravam materializados.

Em sua participação na Mesa-Redonda Internacional de Críticos de Arte, em 1971, na XI Bienal de São Paulo, Mario Schenberg mostrou uma compreensão bastante lúcida dessa questão. O crítico observa que a relação existente entre a arte e as ideias era muito importante, "principalmente agora que estamos com a Arte Conceitual, e outras pesquisas que tomam a idéia como fulcro. Realmente, a arte de nossa época é sobretudo uma arte de idéias" ${ }^{\prime 100}$.

Nesse sentido, a crítica como julgamento com base nas leis do gosto perdeu força, ocasionando tensões entre os artistas (que reivindicavam para si a interpretação de sua obra) de um lado; e os críticos que constataram tardiamente que essas transformações requeriam também uma mudança na tarefa da crítica de arte, de outro ${ }^{101}$.

Longe de entrar em embate com o artista, Mario Schenberg procurava apontar-lhe caminhos possíveis para sua pesquisa. A preocupação esteve dirigida às propostas inovadoras, na medida em que identificava na diversidade de concepções experimentais aquilo que deveria ser valorizado no horizonte das Vanguardas Brasileiras, porquanto apontava valores em gestação.

Constatou-se que a postura de Mario Schenberg estava em consonância com a externalidade do foco da arte desse momento, na medida em que essa não valorizava tanto a forma como valor intrínseco. Ao comentar os critérios do júri de seleção da IX Bienal de São Paulo, o crítico viu com bons olhos o fato de que este teria compreendido o "momento revolucionário atual da arte brasileira e de ter dado prioridade às inovações, mesmo quando apresentadas em obras com deficiências de execução" ${ }^{\prime 102}$.

Mario Schenberg foi um mediador ${ }^{103}$, não um juiz, num momento em que não se podia mais compreender o sentido das obras de arte sem conhecer sua proposta e os conceitos com os quais entravam em diálogo. A partir da atitude do crítico em relação aos debates de então e ao modo como se colocava em relação ao artista, pôde-se afirmar que ele percebeu a necessidade de recolocação do papel do crítico de arte a partir daquele contexto.

\footnotetext{
${ }^{100}$ O crítico completou sua afirmação apresentando uma definição ampliada do termo ideia: “Aí a ideia não deve ser tomada no sentido restrito de uma estrutura lógica, discursiva. Idéia é uma concepção mais ampla. Pode ser um valor, uma vivência, um certo sentimento do mundo ou outras coisas" (destaque do autor). "Mario Schenberg". Transcrição de sua intervenção na Mesa Redonda de 1971. Documento não datado, pp. 4-5. Arquivo Histórico Wanda Svevo, Fundação Bienal (foi mantida a grafia original do texto).

${ }^{101}$ FERREIRA, Glória; COTRIM, Cecília (seleção e comentários). Escritos de artistas: anos 60/70. Tradução de Pedro Süssekind... et al. - 2. Ed. - Rio de Janeiro: Jorge Zahar Ed., 2009.

102 SCHENBERG, Mario. Pensando a Arte, São Paulo: Nova Stella, 1988, p. 194.

${ }^{103}$ Sobre o caráter mediador da personalidade de Mario Schenberg, cf. OLIVEIRA, Alecsandra Matias de. Schenberg: Crítica e Criação. São Paulo: EDUSP, 2012, pp. 112-121.
} 
O papel de sua crítica de arte pôde ser aferido, entre outras coisas, pelo incentivo ao artista, pela busca de compreendê-lo de modo abrangente e sem pressupostos (procurando suas motivações e atitudes perante a arte), pela abertura ao diálogo e, ainda, por ter fornecido instrumentos teóricos e reflexivos que se somavam ao horizonte do artista. Os caminhos apontados por Mario Schenberg indicavam novos pontos de vista a respeito das pesquisas dos artistas, abrindo possibilidades que, muitas vezes, não tinham sido cogitadas por eles. Nesse sentido, foi possível entender a crítica de Mario Schenberg como um ato de criação. 


\section{Conclusão}

Louvo o humanista, o sábio, o artista, o cidadão, o e o amigo de tantas pelejas. Falo do Mario Schenberg que nasceu em Pernambuco, vive em São Paulo e andou pelos quadrantes do mundo com sua tranquila e profunda certeza de que é possível contribuir para que a vida seja melhor para todos os homens ${ }^{1}$.

Jorge Amado.

Mario Schenberg teve uma participação relevante no meio cultural e artístico das décadas de 1960 e 1970. O crítico interagiu com artistas e refletiu sobre os desdobramentos das tendências do período, buscando defini-las e diferenciá-las, tendo em vista sua reflexão acerca de um Novo Humanismo.

Nas Bienais de São Paulo, o crítico se posicionou sempre a favor dos artistas, defendendo a abertura do certame àqueles em começo de carreira, bem como aos que encontravam novos caminhos nas tendências nascentes. Diante das mudanças na configuração da representação brasileira, que visavam maior qualidade e menor número de participantes, Schenberg foi contrário a qualquer ação que pudesse diminuir o número de artistas no certame.

O crítico defendeu, ainda, a abertura da Bienal às novas formas de arte que surgiram no período, como a arte de participação, as proposições e os objetos. Por sua atitude corajosa e firme em relação aos artistas, o Professor Schenberg foi visto por eles como alguém que poderia defender seus interesses perante a organização do evento.

Com relação à crise da Bienal no fim da década de 1960, Schenberg se posicionou, novamente, em favor da arte, porquanto enfatizou que, diante das mudanças profundas ocorridas na arte, se impunha à Bienal a necessidade de acompanhá-las. O surgimento da Arte Conceitual, para o crítico, foi muito relevante, pois mudou o estatuto do objeto, e também do artista, que deixou de lado as técnicas e gêneros tradicionais para atuar em outro plano, o das

\footnotetext{
${ }^{1}$ AMADO, Jorge. In GUINSBURG, Gita K.; GOLDFARB, José Luiz (Org.). Mario Schenberg: Entre-Vistas. São Paulo: Perspectiva, 1984, p.87.
} 
ideias (termo usado por Schenberg em sentido amplo), do qual o objeto funcionava como expressão materializada.

Nas Opiniões e Propostas, o crítico participou do esforço conceitual para definir a arte da Vanguarda Brasileira dos anos de 1960, manifestando seu posicionamento em meio ao debate entre artistas e críticos, a fim de entender as profundas transformações que ocorreram naquele momento. Refletindo sobre os direcionamentos tomados pela arte de então, Mario Schenberg começou a definir sua visão do Novo Realismo, bem como sua relação com o Novo Humanismo, que foi também desenvolvido ao longo da década de 1970.

No entender de Mario Schenberg, o Novo Humanismo ampliou o horizonte vivencial do ser humano, superando as formas de humanismo anteriores. Nos anos de 1960, o crítico foi capaz de perceber que as transformações da realidade histórica pediam novas formas de expressão artística. O Novo Realismo, na medida em que estava centrado na figuração e no homem, tendo assimilado as conquistas das vanguardas anteriores, evidenciava em seu horizonte a ampliação dos referenciais do próprio ser humano.

Em meio a essa reflexão, surgiram aspectos políticos e acadêmicos desse período conturbado da vida do Professor Schenberg que não foram perdidos de vista. Devido a seu posicionamento político, o crítico sofreu perseguição do regime militar após o Golpe de 1964, foi preso por algum tempo e, em 1968, aposentado compulsoriamente de sua função de docente na Universidade de São Paulo. Proibido de frequentar o ambiente universitário, o Professor teve sua carreira como pesquisador prejudicada, passando a se dedicar com mais intensidade à crítica de arte.

A crítica do Professor Schenberg mobilizou um amplo horizonte de referenciais conceituais, como o Marxismo, com o qual teve contato ainda na juventude, por meio do qual percebeu que a História tinha também uma dimensão teórica, não sendo apenas uma sucessão de acontecimentos ${ }^{2}$. Outro marco conceitual foi o inconsciente coletivo de Carl Jung ${ }^{3}$. Se a descoberta do inconsciente por Sigmund Freud representou a ampliação das fronteiras da vida mental do homem em nível individual, o inconsciente coletivo junguiano expandiu ainda mais esse território, porquanto permitiu a Schenberg conceber, na história da cultura, a manifestação de estruturas fundamentais ${ }^{4}$.

Também o pensamento e a arte do Oriente foram muito caros ao crítico e marcaram sua visão de mundo. No início da década de 1940, Schenberg viajou para os Estados Unidos

\footnotetext{
${ }^{2}$ SCHENBERG, Mario. Diálogos com Mario Schenberg. São Paulo: Nova Stella, 1988, p. 21.

${ }^{3}$ Cf. JUNG, Carl. Tipos Psicológicos (Rio de Janeiro: Zahar Editores, 1974) e Memória, Sonhos, Reflexões (Rio de Janeiro: Nova Fronteira, 1970).

${ }^{4}$ GOLDFARB, José Luiz. Voar também é com os Homens São Paulo: EDUSP, 1994.
} 
como pesquisador, onde teve contato com a filosofia oriental. Além dos conceitos de Ying e Yang, que descobriu com Wolfgang Pauli, o crítico encontrou um livro de Oswald Siren, grande conhecedor de arte chinesa. Tratava-se de uma compilação de textos chineses tradicionais sobre pintura e arte, que marcou a visão do crítico. O livro foi importante para a formação de Mario Schenberg abrindo-lhe todo um horizonte conceitual, porquanto apresentou ao crítico uma perspectiva da relação entre a arte e a filosofia ${ }^{5}$.

No campo da história da ciência, estavam presentes revisões que o Professor Schenberg considerava importantes. Autores como Henri Poincaré e Albert Einstein apontavam que a lógica e a razão eram, sem dúvida, importantes na demonstração e na operacionalização das descobertas cientificas, mas a intuição e a imaginação é que permitiam criar $^{6}$. Tendo em vista essas referências, Schenberg desenvolveu sua concepção a respeito da importância da intuição como elemento criativo tanto na ciência, quanto na arte.

A concepção de um Novo Humanismo que o Professor Schenberg desenvolveu ao longo desse período estava inserida nessa ambientação histórica e dialogava com ela, colocando-se como uma ampliação da dimensão do humanismo, porquanto se estenderia todas as esferas da vida social e espiritual do homem. Caracterizado por uma "síntese do individual, do social, do existencial e do cósmico"7, seu Novo Humanismo superava as formas de humanismo anteriores que eram, em seu entender, deficientes em relação ao existencial e ao cósmico e tendiam a opor as esferas do individual e do social ${ }^{8}$.

A ênfase sobre a descoberta do inconsciente e o desenvolvimento tecnológico foram elementos importantes dessa abertura. No primeiro caso, as fronteiras do próprio ser humano se expandiram, a partir da noção de que a esfera da consciência constituía apenas uma parte de sua vida mental. No segundo, colocou-se a preocupação com a falta de humanização do desenvolvimento tecnológico, ligado às demandas do mercado, bem como a degradação ambiental decorrente da atividade industrial.

Também fez parte desse quadro a ameaça de uma guerra nuclear, que trazia em seu bojo a possibilidade de extermínio maciço e até mesmo a extinção da humanidade. Desde o fim da Segunda Guerra Mundial, em 1945, a tensão entre Estados Unidos e União Soviética fazia parte da ambientação desse momento histórico, polarizando as relações internacionais.

\footnotetext{
${ }^{5}$ SCHENBERG, Mario. Diálogos com Mario Schenberg. São Paulo: Nova Stella, 1988, p. 31).

${ }^{6}$ Cf. POINCARÈ, Henri. Valor da ciência (Rioo de Janeiro: Contraponto, 1995), POINCARÉ, Henri. Science et méthode (Paris: Flammarion, 1947), EINSTEIN, Albert. Como vejo o mundo (Rio de Janeiro: Editora Nova Fronteira, 1981).

${ }^{7}$ SCHENBERG, Mario. Um Novo Realismo. In Pensando a Arte. São Paulo Nova Stella, 1988, p. 185.

${ }^{8}$ SCHENBERG, Mario. Um Novo Realismo. In Pensando a Arte. São Paulo Nova Stella, 1988, p. 185.
} 
Em função de tudo isso, pôde-se chegar à seguinte síntese: considerado por Mario Schenberg a expressão artística do Novo Humanismo, o Novo Realismo foi definido a partir de um horizonte paralelo: fruto da sociedade industrial e reflexo da cultura ocidental em crise, essa tendência refletiu um momento de ampliação de referenciais. Para o crítico, o "realismo renascentista, que se prolongou até a Primeira Guerra Mundial, correspondia ao humanismo individualista e burguês, predominante durante aquele período. [...] O humanismo atual é eminentemente democrático e social" "9. A partir dessa nova ênfase, o Novo Realismo ia além da valorização do aspecto formal, do requinte artesanal e da valorização do material nobre, levando em consideração o repertório de imagens e símbolos do cotidiano que cercavam a realidade da sociedade ocidental ${ }^{10}$.

No entender de Mario Schenberg, tendências vizinhas do Novo Realismo como o Realismo Fantástico e o Realismo Mágico, convergiam mais explicitamente para o fato de que o inconsciente constitui grande parte da vida mental do ser humano, enquanto a consciência representa parte limitada da psique. O peso dessas tendências residia no fato de que "correspondem à necessidade profunda do homem contemporâneo de superar a rigidez das barreiras que a cultura pós-renascentista ocidental estabeleceu entre a percepção positivista e outras formas oníricas, fantásticas, etc" ${ }^{\prime 1}$.

Foi possível perceber que, na medida em que o Novo Realismo de Mario Schenberg envolvia uma perspectiva abrangente em relação ao ser humano, pôde responder melhor à reflexão dos artistas da Nova Objetividade Brasileira, porquanto enfatizou a dimensão vivencial das pesquisas dos artistas que seguiam os caminhos de uma Arte de Participação.

O Novo Humanismo também esteve presente nas críticas dos anos de 1970, nas quais Mario Schenberg esteve atento à revisão da contribuição de artistas e movimentos das décadas anteriores, especialmente dos anos de 1940, 1950 e 1960. Escreveu sobre artistas do Grupo Santa Helena, levantando aspectos como a preocupação com o rumo do desenvolvimentismo tecnológico que não levava em consideração a conservação dos recursos naturais do planeta. Estiveram presentes na reavaliação que o crítico fez de artistas como Rebolo Gonsales, Aldo Bonadei, Manoel Martins e Alfredo Volpi.

O crítico reconheceu, ainda, a importância dos movimentos Concreto e Neoconcreto, pois tinha convicção de que marcaram a arte brasileira ao possibilitar contribuições altamente

\footnotetext{
${ }^{9}$ SCHENBERG, Mario. Pensando a Arte. São Paulo Nova Stella, 1988, p. 186.

${ }^{10}$ SCHENBERG, Mario. Pensando a Arte. São Paulo Nova Stella, 1988, p. 186.

${ }^{11}$ SCHENBERG, Mario. Pensando a Arte. São Paulo Nova Stella, 1988. p. 64.
} 
criativas e de relevância internacional ${ }^{12}$. Figuraram em seus textos sobre o assunto, artistas como Waldemar Cordeiro, Hélio Oiticica, Mira Schendel e Lygia Clark.

As análises realizadas por Mario Schenberg nesse momento levaram em conta a relação entre a Arte, a Tecnologia e a Natureza, na medida em que o crítico identificou, paralelamente ao esforço do olhar retrospectivo, tendências como Arte Ecológica e Arte Catastrófica, que tinham em seu horizonte a degradação da Natureza pela atividade industrial. O crítico percebeu, nessas tendências, uma aproximação com o pensamento oriental, na medida em que este concebia uma profunda união entre o homem e a Natureza. A estética do Oriente é um aspecto privilegiado na visão do crítico em relação ao trabalho de Mira Schendel.

As considerações feitas por Schenberg sobre tendências que chamou de Arte Ecológica e Arte Catastrófica mostraram que o crítico identificou caminhos diferentes daqueles de 1960. O Novo Humanismo continuou no horizonte de Mario Schenberg, então manifestado na relação do homem com a Natureza, aspecto que não apareceu de modo tão contundente na década anterior.

Nos anos de 1970 o crítico fez, também, observações acerca da volta à pintura, pontuando que os artistas voltavam a utilizar técnicas tradicionais - como a pintura à óleo, por exemplo - para expressar questões daquele momento. Foi enfatizado que, para o Professor Schenberg, as possibilidades da pintura não estavam esgotadas, o que era confirmado pelos artistas que, utilizando seus recursos, encontravam os caminhos da década de 1970.

José Luiz Goldfarb fez importantes considerações sobre as características dos textos críticos de Mario Schenberg, apontando a surpreendente densidade de seu discurso: cada frase de seus textos críticos era repleta de vivências e da complexidade do pensamento do crítico; cada análise, repleta de aberturas, direcionamentos e interpretações ${ }^{13}$. Ao tecer suas críticas, Mario Schenberg também criava algo novo, a partir da obra de arte, de seu conhecimento do artista que a elaborou e de si mesmo. Sua crítica também era criativa e criadora. Criativa, pois ia além de uma interpretação da obra a partir de uma perspectiva normativa; criadora, pois fornecia ao artista novos horizontes para seu desenvolvimento artístico ao revelar, muitas vezes, aspectos dos quais o próprio artista não havia tomado consciência.

Outro aspecto apontado pelo autor a respeito da personalidade do critico dizia respeito à importância do diálogo no movimento de seu pensamento ${ }^{14}$. Mario Schenberg estava

\footnotetext{
${ }^{12}$ SCHENBERG, Mario. Pensando a Arte. São Paulo Nova Stella, 1988.

${ }^{13}$ GOLDFARB, José Luiz. Voar também é com os Homens. São Paulo: EDUSP, 1994, p. 129.

${ }^{14}$ GOLDFARB, José Luiz. Voar também é com os Homens. São Paulo: EDUSP, 1994, p.57.
} 
interessado no movimento de reflexão que, expresso oralmente, poderia surpreender ao revelar novos aspectos de uma ideia, mesmo uma já bastante abordada. Para Schenberg, o pensamento era criativo na fala, enquanto o texto escrito apresentava-se fechado e imóvel ${ }^{15}$. Por isso, o crítico não tinha muito interesse em registrar por escrito suas reflexões filosóficas, que podem ser encontradas com mais frequência em entrevistas e livros como Diálogos com Mario Schenberg (São Paulo: Nova Stella, 1985), por exemplo, elaborados a partir de gravações de sua fala. A marca da oralidade está presente de modo notável nas análises que Schenberg fez de artistas e tendências que, apesar de datilografadas pelo próprio crítico, procuravam manter o instante vívido de sua reflexão.

Percebeu-se que Mario Schenberg soube, enquanto crítico de arte, compreender as demandas da arte nascente, na medida em que sua atividade crítica não se deu como julgamento e avaliação, mas como compreensão e incentivo. A abertura do crítico em relação aos novos valores expressos pelos artistas, somada ao horizonte de referências de seu pensamento, permitiu ao crítico refletir sobre a arte dos anos de 1960 e 1970 a partir de uma perspectiva diferenciada.

Por fim considerou-se apropriado pontuar que muitos aspectos da participação de Mario Schenberg nas Bienais de São Paulo, bem como nas exposições Opinião 65, Propostas 65, Opinião 66 e Propostas 66, não puderam ser aprofundados neste estudo e, nesse sentido, constituem caminhos passíveis de exploração em estudos posteriores. Da mesma forma, a densidade da crítica de arte do Professor Schenberg não foi esgotada: suas análises apresentaram muitos artistas, referenciais e perspectivas que merecem ser aprofundados no futuro.

${ }^{15}$ GOLDFARB, José Luiz. Voar também é com os Homens. São Paulo: EDUSP, 1994, p.57. 


\section{Referências $^{1}$}

\section{Específicas}

\section{Livros e Capítulos}

AJZENBERG, Elza. M. Schenberg: a crítica e o olhar da descoberta. In: O mundo de Mario Schenberg. São Paulo: Casa das Rosas, 1996.

2001). . (org.). Schenberg - Arte e Ciência. São Paulo: ECA USP (Coleção, 1995 -

CAMPOS, Haroldo de. Apresentação. In GOLDFARB, José Luiz. Voar também é com os Homens. São Paulo: EDUSP, 1994.

CEDRAN, Lourdes (Coord.). Diálogos com Mario Schenberg. São Paulo: Nova Stella, 1985.

CEDRAN, Lourdes. Lourdes Cedran. In SCHENBERG, Mario. Mario Schenberg: EntreVistas. São Paulo: Perspectiva, 1984.

CLARK, Lygia. Lygia Clark. In SCHENBERG, Mario. Mario Schenberg: Entre-Vistas. São Paulo: Perspectiva, 1984.

CENTRO DE ESTUDOS DE ARTE CONTEMPORÂNEA. Arte em revista. São Paulo, Centro de Estudos de Arte Contemporânea, 1979-.

FERNANDES. Eva. Mario: Crítico de Arte. In AJZENBERG, Elza. Schenberg: Arte e Ciência. São Paulo: ECA/USP, 1997, pp. 82-6.

GOLDFARB, José Luiz. Voar também é com os Homens. São Paulo: EDUSP, 1994. . José Luis Goldfarb. In AJZENBERG, Elza. In Schenberg: Arte e Ciência. São Paulo: ECA/USP, 1997, pp. 43-50.

GUINSBURG, Gita K.; GOLDFARB, José Luiz (Org.). Mario Schenberg: Entre-Vistas. São Paulo: Perspectiva, 1984.

GULLAR, Ferreira \& PEDROSA, Mário. Arte brasileira hoje: situação e perspectivas. Rio de Janeiro: Paz e Terra, 1973.

\footnotetext{
${ }^{1}$ De acordo com a Associação Brasileira de Normas Técnicas. NBR 6023.
} 
HAMBURGUER, Amélia Império et al. Obra Científica de Mario Schenberg. Volume 1. São Paulo: EDUSP, 2009.

LIMA, Maurício Nogueira. Mario Schenberg: incentivador e crítico. In AJZENBERG, Elza (org.). Schenberg - Arte e Ciência. São Paulo, 1995, pp. 40-43.

MAIA, Dulce. Jorge Mautner e Dulce Maia. In SCHENBERG, Mario. Mario Schenberg: Entre-Vistas. São Paulo: Perspectiva, 1984.

OITICICA, Hélio. Situação da Vanguarda no Brasil (Propostas 66). In FERREIRA, Glória (org.). Crítica de arte no Brasil: temáticas contemporâneas. Rio de Janeiro: Funarte, 2006.

. Esquema Geral da Nova Objetividade. In FERREIRA, Glória; COTRIM, Cecília (seleção e comentários). Escritos de artistas: anos 60/70. Tradução de Pedro Süssekind. et al. - 2. Ed. - Rio de Janeiro: Jorge Zahar Ed., 2009.

OLIVEIRA, Alecsandra Matias. Schenberg: Crítica e Criação. São Paulo: EDUSP, 2011.

SCHENBERG, Mario. Depoimento. In AJZENBERG, Elza. Schenberg - Arte e Ciência. São Paulo: ECA/USP, 1995, p. 142.

. Pensando a Física. São Paulo: Nova Stella Editorial, 1990.

. Pensando a Arte, São Paulo: Nova Stella, 1988.

. Diálogos com Mario Schenberg. São Paulo: Nova Stella Editorial, 1985.

. Mario Schenberg: Entre-Vistas. São Paulo: Perspectiva, 1984.

. Arte e Tecnologia. In GULLAR, Ferreira \& PEDROSA, Mário. Arte brasileira hoje: situação e perspectivas. Rio de Janeiro: Paz e Terra, 1973.

\section{Relatórios}

CENTRO MARIO SCHENBERG DE DOCUMENTAÇÃO DA PESQUISA EM ARTES.

Documentação: arte e ciência. (coord. Elza Ajzenberg). São Paulo: Centro Mario Schenberg/ECAUSP, 1994.

\section{Artigos}

AMARAL, Aracy. Terminada a Seleção da Bienal. A Gazeta, São Paulo (capital), 18/05/1965.

AMARAL, Aracy. Revisão da VIII Bienal. O Estado de São Paulo, 11/12/1965. 
BARROS Alberto Luis da Rocha. Schenberg: Nada do que é Humano lhe era Estranho. In Estudos Avançados, 11(5), 1991.

COUTO, Maria de Fátima Morethy. Arte engajada e transformação social: Hélio Oiticica e a exposição Nova Objetividade Brasileira. In Revista Estudos Históricos. Rio de Janeiro, vol. $25, \mathrm{n}^{\mathrm{o}} .49$, jan-jun de 2012, p. 71-87.

HAMBURGUER, Amélia Império. Nota biográfica e entrevista com Mario Schenberg (Novembro, 1983). São Paulo: Instituto de Física, Universidade de São Paulo, 1984.

KINOSHITA, Dina. A Política para Mario Schenberg, s.p. (texto digitado - Arquivo do Centro Mario Schenberg de Documentação da Pesquisa em Artes - ECA/USP).

LIMA, Mônica Rodrigues de. Schenberg e o concretismo de Waldemar Cordeiro. In CENTRO MARIOSHCNBERG DE DOCUMENTAÇÃO DA PESQUISA EM ARTES. Documentação: arte e ciência. (coord. Elza Ajzenberg). São Paulo: Centro Mario Schenberg/ECA-USP, 1994.

MAURÍCIO, Jayme. Bienal: eleitos dos artistas. Correio da Manhã, 06/06/67.

PISMEL, Ana Paula Cattai. Schenberg e vanguardas: Crítica como parceria. In: VIII Congresso de Estética e História da Arte, Desenhos da Pesquisa: Novas Metodologias da Pesquisa em Arte. São Paulo: Museu de Arte Contemporânea da Universidade de São Paulo, 2012. v.1. p. $279-288$.

SCHENBERG, Mario. Caminhos da Arte de Hoje, Jornal do Brasil (Rio de Janeiro),27/09/1969.

. Entrevista com Mario Schenberg. (Publicado originalmente na Revista Trans/Form/Ação, v. 3, p. 6-62, 1980). In Trans/Form/Ação. Marília, v.34, 2011. Edição Especial.

. Exposição dos sete. Arquivo do Centro Mario Schenberg de Documentação da Pesquisa em Arte - ECA/USP. Texto não datado.

. Formação da Mentalidade Científica. In Estudos Avançados, 12(5), 1991, pp.

$123-151$.

José Roberto Aguilar. Centro Mario Schenberg de Documentação da Pesquisa em Artes - ECA/USP. Texto datado de 1964.

- Lygia Clark. Arquivo do Centro Mario Schenberg de Documentação da Pesquisa em Arte - ECA/USP. Texto datado de set. 1984.

. Mário Gruber: um Realista Fantástico Brasileiro. Centro Mario Schenberg de Documentação da Pesquisa em Artes - ECA/USP. Texto datado de 1970, s/p..

- Paisagens de Mira Schendel. Arquivo do Centro Mario Schenberg de Documentação da Pesquisa em Arte - ECA/USP. Texto datado de 1979. 
1979.

. O Ponto Alto. In Arte em Revista ( ${ }^{\circ}$ 2), São Paulo, CEAC, Maio-Agosto, . O espaço social do Artista. Arquivo Centro Mario Schenberg de

Documentação da Pesquisa em Artes. Texto não datado.

- Arte de Participação. Arquivo do Centro Mario Schenberg de Documentação

da Pesquisa em Arte - ECA/USP. Texto não datado.

ZANINI, Ivo. Indicado o Júri da VIII Bienal. Folha Ilustrada (São Paulo - Capital). 27/04/1965.

Artistas a favor do crítico, s/p, s/d, sem identificação de jornal.

Críticos de Arte vão debater reformulação das bienais. Nota enviada à imprensa, documento não datado. Arquivo Histórico Wanda Svevo, Fundação Bienal.

Mario Schenberg. Jornal Folhetim, 24 de julho de 1977.

Schenberg em Vez de Milliet. Correio da Manhã (Estado da Guanabara). 07/05/1965.

Schenberg fica. Correio da Manhã, 06/06/67.

Júri já escolheu artistas brasileiros para a Bienal Internacional de Artes. Nota divulgada à imprensa. Documento datilografado, datado de 11/09/1970. Arquivo Histórico Wanda Svevo, Fundação Bienal.

Júri da X Bienal convida vinte e cinco artistas, nota divulgada à imprensa pela Fundação Bienal, em 28 de maio de 1969. Arquivo Histórico Wanda Svevo, Fundação Bienal.

Mario Schenberg. Transcrição de sua intervenção na Mesa Redonda de 1971. Documento não datado. Arquivo Histórico Wanda Svevo, Fundação Bienal.

Programação da Mesa Redonda de Críticos de Arte - X Bienal. Documento não datado. Arquivo Histórico Wanda Svevo, Fundação Bienal.

Teses

AJZENBERG, Elza. Exercícios Estéticos da Liberdade. São Paulo: ECA USP, 1989 (tese de livre docência).

\section{Catálogos}

AGUILAR, José Roberto. O mundo de Mario Schenberg. São Paulo: Casa das Rosas, 1996. 
SCHENBERG, Mario. Alfredo Volpi. In FUNDAÇÃO BIENAL, VI Bienal. . (catálogo de exposição) São Paulo: Fundação Bienal, 1961.

SHCNBERG, Mario. Novos Valores, in FUNDAÇÃO BIENAL. X Bienal. (catálogo de exposição) São Paulo: Museu de Arte Moderna de São Paulo, 1969.

\section{Cartas}

Carta de Mário Pedrosa a Mario Schenberg, de 02 de fevereiro de 1961. Arquivo Histórico Wanda Svevo, Fundação Bienal.

Carta de Maurício Nogueira Lima (Presidente da AIAP) a Francisco Matarazzo Sobrinho, datada de 16 de maio de 1969. Arquivo Histórico Wanda Svevo, Fundação Bienal.

\section{Atas}

Ata do Júri de Seleção, dia 26/06/1969. Arquivo Histórico Wanda Svevo, Fundação Bienal.

Ata do Júri de Seleção, dia 07/07/1969. Arquivo Histórico Wanda Svevo, Fundação Bienal.

Ata da apuração de apuração da eleição do representante dos artistas no Júri de Seleção da XI Bienal. Documento manuscrito, datado de 31 de agosto de 1970. Arquivo Histórico Wanda Svevo, Fundação Bienal.

Sites

SCHENBERG, Mario. Entrevista com Mario Schenberg. In Revista Brasileira de Ensino de Física, pt. 1vol. 1, no 2, 1979. (Entrevista publicada inicialmente no jornal O Estado de São Paulo, edição de 10/12/1978). Disponível em: http://www.sbfisica.org.br//bef/pdf/vol01a18.pd Acesso em 16/Fev/2012.

CENTRO MARIO SHCENBERG DE DOCUMENTAÇÃO DA PESQUISA EM ARTES. Disponível em:

http://www.eca.usp.br/nucleos/cms/index.php?option=com content\&view=section\&id $=2 \& I t e m i d=3$ Acessado em 03/Jul/2012.

FILHO, Antônio Gonçalves. Schenberg Pensa a Arte. Folha de São Paulo, 19/mar/1988, Livros, p. D - 4. Disponível em http://acervo.folha.com.br/fsp/1988/03/19/349//4147898 Acesso em 20/Jan/2012.

\section{Arquivos}


Arquivo do Centro Mario Schenberg de Documentação da Pesquisa em Artes. Universidade de São Paulo

Av. Prof. Lúcio Martins Rodrigues, 433, bloco B9, sala 9

05508-900 - São Paulo - SP - Brasil

\section{Arquivo Histórico Wanda Svevo}

Fundação Bienal de São Paulo

Pavilhão Ciccillo Matarazzo

Parque do Ibirapuera - Portão 3

04094-000

São Paulo - SP - Brasil

\section{Gerais}

\section{Livros e Capítulos}

ADUSP. O livro negro da USP: controle ideológico na Universidade (1964-1978). São Paulo: Adusp, 2004.

ALAMBERT, Francisco e LOPES, Polyana Canhête. As Bienais de São Paulo: da Era dos Museus à Era dos Curadores (1951- 2001), São Paulo: Boitempo, 2004. 256 pp.

ALVARADO, Daisy Valle Machado Peccinini de. Figurações Brasil Anos 60: Neofigurações Fantásticas e Neosurrealismo, Novo Realismo e Nova Objetividade. São Paulo: Itaú Cultural/Edusp, 1999.

AMARAL, Aracy A. (org.) Projeto construtivo na arte brasileira: 1950-1962. (catálogo de exposição) Rio de Janeiro: Museu de Arte Moderna; são Paulo, Pinacoteca do Estado, 1977.

AMARANTE, Leonor. As Bienais de São Paulo: 1951-1987. São Paulo: Projeto, 1989. 407 pp.

ARANTES, Otília Beatriz Fiori. Mário Pedrosa Itinerário crítico. São Paulo, Cosac Naify, 2004.

ARCHER, Michael. Arte Contemporânea. São Paulo: Martins Fontes, 2008, $2^{\text {a }}$ Edição.

ARGAN, Giulio Carlo. As Fontes da Arte Moderna (trad. Rodrigo Naves). Novos Estudos (18), São Paulo, CEBRAP, set. 1987.

BERGSON, Henri. Ensaio sobre os Dados Imediatos da Consciência, Lisboa, Edições 70.

BLACKBURN, Simon. (Ed.). Dicionário Oxford de Filosofia. Rio de Janeiro: Jorge Zahar Editor, 1997. 
BRITO, Ronaldo. Neoconcretismo: Vértice e ruptura do projeto construtivo brasileiro. São Paulo: Cosac \& Naify, 1999.

BRODRICK, Alan Houghton. La pintura china. México Fondo de Cultura Económica, 1954.

CHIANG Yee. Chinese calligraphy - an introduction to its aesthetic and technique with a foreword by Sir Herbert Read. London Methuen 1954.

COSTA, Helouise; BOEHRINGER, Vivian. WALDEMAR Cordeiro: a ruptura como metáfora. São Paulo: Cosac \& Naify : Centro Universitário Maria Antônia, 2002.

ECO, Umberto. Como se faz uma tese. $23^{\text {a }}$ edição. São Paulo: Perspectiva, 2010.

FAVARETTO, Celso Fernando. A invenção de Hélio Oiticica. 2. ed. São Paulo, EDUSP, FAPESP, 2000. (col. Texto e Arte, 6).

EINSTEIN, Albert. Como vejo o mundo. Tradução de H. P. de Andrade. Rio de Janeiro: Editora Nova Fronteira, 1981.

FERREIRA, Glória \& COTRIM, Cecília (seleção e comentários). Escritos de artistas: anos 60/70. Tradução de Pedro Süssekind... et al. - 2. Ed. - Rio de Janeiro: Jorge Zahar Ed., 2009.

FERREIRA, Glória. Crítica de arte no Brasil: temáticas contemporâneas. Rio de Janeiro: Funarte, 2006.

FERREIRA, Glória; COTRIM, Cecília (seleção e comentários). Escritos de artistas: anos 60/70. Tradução de Pedro Süssekind... et al. - 2. Ed. - Rio de Janeiro: Jorge Zahar Ed., 2009.

FUNDAÇÃO BIENAL DE SÃO PAULO. Anais do Simpósio sôbre Ciência e Humanismo. São Paulo: outubro de 1971.

GOMBRICH, Ernest. História da Arte. Rio de Janeiro: LTC, 2009.

HUYGHE, René. Dialogue avec le visible. Paris: Flammarion, 1955.

JUNG, Carl. Tipos Psicológicos. Rio de Janeiro: Zahar Editores, 1974.

JUNG, Carl. Memória, Sonhos, Reflexões. Rio de Janeiro: Nova Fronteira, 1970.

KANDINSKY, Wassily. Do Espiritual na Arte, e na pintura em particular. São Paulo: Martins Fontes, 1996.

MARQUES, Maria Eduarda. Mira Schendel. São Paulo: Cosac \& Naify Edições 2001.

PEDROSA, Mário. Política das Artes, (org.) Otília Beatriz Fiori Arantes. São Paulo: EDUSP, 1995. 
PEDROSA, Mário. Mundo, Homem, Arte em crise. (Org. Aracy Amaral). São Paulo: Perspectiva, 1995.

PEDrosA, Mário. A Bienal de Cá para Lá. In Mundo, Homem, Arte em crise. (Org. Aracy Amaral). São Paulo: Perspectiva, 1995.

PEDROSA, Mário. Opinião... Opinião... Opinião... in Mundo, Homem, Arte em crise. São Paulo: Perspectiva, 1975.

POINCARÈ, Henri. Valor da ciência. (tradução Maria Helena Franco Martins ; revisão técnica Ildeu de Castro Moreira) Rio de Janeiro: Contraponto, 1995.

READ, Herbert. Arte e Alienação. Rio de Janeiro: Zahar Editores, 1968.

RESTANY, Pierre. Os Novos Realistas. São Paulo: Perspectiva, 1979.

SEVERINO, Joaquim Antônio. Metodologia do Trabalho Científico. 23ª edição revista e atualizada. São Paulo: Cortez, 2007.

SUN CHIA CHIN. Poesia e Pintura Chinesa. Revista China em Estudo, ano 1, nº 1, 1994, pp. 83-88.

SZE, Mai-mai. The Tao of painting - a study of the ritual disposition of Chinese painting, with a translation of the Chieh Tzu Yuän Hua Chaun, or, Mustard seed garden manual of painting, 1679-1701. Londres: Routledge \& K. Paul 1957.

\section{Artigos}

ALMEIDA, Paulo Mendes de. A próxima Bienal. O Estado de São Paulo, São Paulo (capital), 26/06/1965.

AMARAL, Aracy. Bienais ou Da impossibilidade de reter o tempo. REVISTA USP, São Paulo, n. 52, p. 16-25, dezembro/fevereiro 2001-2002.

AMARAL, Aracy. Arte no Brasil. In CENTRO DE ESTUDOS DE ARTE CONTEMPORÂNEA. Arte em Revista, em 1979, ano I, no . 2, p. 29.

ARANTES, Otília Beatriz Fiori. Depois das Vanguardas, in Arte em Revista, São Paulo, 5 (7), 1983, pp. 5-20.

De Opinião-65 a XVIII Bienal. In: Novos Estudos. (15), São Paulo, CEBRAP, jul.1986. pp. 69-84.

AYALA, Walmir. A Bienal em Questão. Jornal do Brasil (Rio de Janeiro), 27/09/1969.

AYALA, Walmir. Júris, pra quê?, Jornal do Comércio (Rio de Janeiro), 14/10/1969 
BARATA, Mário. Opinião 65: Artes Visuais de Vanguarda (Seminário Propostas 66). Arte em Revista (nº 2), São Paulo, CEAC, Maio-Agosto, 1979, p. 35- 6.

BARATA, Mário. Aspectos Organizativos da Bienal. Jornal do Comércio (Rio de Janeiro), $12 / 10 / 1969$

CORDEIRO, Waldemar. Todos Atentos. Artes: Ano I, nº 3, jan. 1966.

D’HORTA, Arnaldo Pedroso. Ainda a Bienal, Jornal da Tarde (São Paulo), 22/10/1969.

FAVERATO, Celso Fernando. A outra América. Jornal Folha de São Paulo, 09 de junho de 2001 .

Opinião de lá para cá. Folha de São Paulo, São Paulo, 03 jul. 1995, p. 20.

FERRO, Sérgio. Os Limites da Denúncia (Jornal Rex Time). In Arte em Revista ( $n^{\circ}$ 1), São Paulo, CEAC, Jan-Mar, 1970, p. 84-5. 1979, p. 26.

. Vale Tudo (Artes). In Arte em Revista, (n 2), São Paulo, CEAC, Maio-Agosto,

GULLAR, Ferreira. Opinião 65 (Revista Civilização Brasileira). In Arte em Revista (nº 2), São Paulo, CEAC, Maio-Agosto, 1979.

JORDÂO, Vera Pacheco. Os críticos e a Bienal. O Globo (Estado da Guanabara), $17 / 08 / 1965$.

MORAIS, Frederico. Mesa redonda e Protesto. Diário de Notícias (Rio de Janeiro) em 03/10/1969

SCHWARZ, Roberto. Cultura e Política, 1964-69, in O Pai de Família e outros estudos. Rio de Janeiro: Paz e Terra, 1978.

VIEIRA, José Geraldo. Aula Maior. Artes: Ano I, nº 3, jan. 1966.

Folha registrou trajetória de FHC, da USP à Presidência. Jornal Folha de São Paulo. 18 de junho de 2011.

AIAP e ABCA recusam convite da Bienal. Folha de São Paulo, 01 de fevereiro de 1969.

Ciência \& Arte: X Bienal de São Paulo. Diário Popular, 19/10/1969.

Cientistas e humanistas na Bienal de Ciências. Folha Ilustrada, 11/04/1969.

$O$ corte foi duro, registrado o maior índice de recusa de todas as bienais: $80 \%$ dos inscritos foram recusados. Correio da Manhã (Estado da Guanabara), 19/05/1965.

Pré-Bienal começa no dia 12 com artistas de 21 estados. Nota divulgada à imprensa, datilografada, datada de 3/09/1970. Arquivo Histórico Wanda Svevo, Fundação Bienal. 
Recomendações da Mesa Redonda de críticos de arte internacionais, não datado, com duas páginas. Arquivo Histórico Wanda Svevo, Fundação Bienal.

Regulamento da Pré-Bienal de São Paulo. Documento datilografado, datado de 20 de janeiro de 1970. Arquivo Histórico Wanda Svevo, Fundação Bienal.

Regimento Interno do evento. Documento não datado. Arquivo Histórico Wanda Svevo, Fundação Bienal.

Relatório das Atividades em 1971. Documento datilografado, datado do mês de janeiro de 1972. Arquivo Histórico Wanda Svevo, Fundação Bienal.

S. Paulo abrigará Bienal de Ciência. O Estado de São Paulo, 02/06/1967.

Teses

CLEMENTE, José Eduardo Ferraz. Ciência e política durante a ditadura militar: o caso da comunidade brasileira de físicos (1964-1979). Salvador: Universidade Federal da Bahia, Instituto de Física, 2005. (dissertação de Mestrado).

\section{Catálogos}

AJZENBERG, Elza Maria (org.). Operários na Paulista: MAC USP e artistas artesãos. Apresentação Horácio Lafer Piva, Elza Maria Ajzenberg; introdução Daisy Valle Machado Peccinini de Alvarado. São Paulo: MAC, 2002. 92 p., il. p\&b color.

CENTRO CULTURAL BANCO DO BRASIL. Opinião 65 - 30 Anos. (catálogo de exposição) Rio de Janeiro: Centro Cultural Banco do Brasil, 1995.

FUNDAÇÃO BIENAL DE SÃO PAULO. 50 anos Bienal de São Paulo: 1951-2001. (catálogo de exposição) São Paulo: Fundação, 2001.

. XI Bienal. (catálogo de exposição). São Paulo: Fundação Bienal, 1971.

. X Bienal. (catálogo de exposição) São Paulo: Fundação Bienal, 1969.

. IX Bienal. (catálogo de exposição) São Paulo: Fundação Bienal, 1967.

. VIII Bienal. (catálogo de exposição) São Paulo: Fundação Bienal, 1965.

. VI Bienal. (catálogo de exposição) São Paulo: Fundação Bienal, 1961.

Paulo, 1953.

II Bienal. (catálogo de exposição) São Paulo: Museu de Arte Moderna de São 
GALERIA DE ARTE BANERJ. Ciclo de Exposições sobre Arte no Rio de Janeiro:

5. Opinião 65 (catálogo de exposição) Rio de Janeiro: Galeria de Arte Banerj, 1985.

MUSEU DE ARTE MODERNA DO RIO DE JANEIRO. Opinião 66 (catálogo de exposição) Rio de Janeiro: MAM, 1966.

MUSEU DE ARTE MODERNA - RJ. Opinião 66. (folheto de exposição). São Paulo, 1966. É interessante notar que, dessa vez, todos os artistas brasileiros eram cariocas ou residiam no Rio de Janeiro.

WARHOL, Andy. Catálogo de exposição. Andy Warhol: Mr. América. Catálogo de exposição. São Paulo: Pinacoteca do Estado, 2010.

\section{Cartas}

Carta de Mário Pedrosa a Theon Spanudis, de 22 de dezembro de 1960.

Carta de Walter Zanini à Diná Coelho Lopes, de 30 de abril de 1961.

Carta de Quirino Campofiorito ( $1^{\circ}$ Vice-Presidente da AICA) e Mirian Quiaverini (Presidente da AIAP) a Francisco Matarazzo Sobrinho, datada de 31 de Janeiro de 1969.

Carta de Francisco Matarazzo Sobrinho a Maurício Nogueira Lima (Presidente da AIAP), datada de 2 de maio de 1969.

Telegrama de Edyla Mangabeira Unger à Fundação Bienal, datado de 25 de Setembro de 1969.

Telegrama assinado pelos críticos: Pedro Manuel Gismondi, Antônio Bento, Aracy Amaral, Maria Eugênia Franco, José Roberto Teixeira Leite, Theon Spanudis, Waldemar Cordeiro e Walter Zanini à Fundação Bienal, datado de 25 de setembro de 1969. Arquivo Histórico Wanda Svevo, Fundação Bienal.

\section{Sites}

ALVARADO, Daisy Valle Machado Peccinini de. Figurações no Brasil: anos 60. In: Projeto Visitando o MAC na Web. Disponível em http:/www.mac.usp.br/mac/templates/projetos/seculoxx/modulo4/abertura/index.html Acesso em: 10/Nov/2011.

CHIARELLI, Tadeu. Considerações breves sobre a arte contemporânea e o papel das instituições. In Revista Itaú Cultural. Disponível em:

http://www.itaucultural.org.br/impressao.cfm?materia=847 Acesso em 13/Nov/2011.

DIÁRIO OFICIAL DA UNIÃO. ATO Complementar no 75, de 21 de outubro de 1969, p. 8930. Disponível em: http://www.planalto.gov.br/ccivil 03/ACP/acp-75-69.htm Acesso em: 20/02/20013. 
FUNDAÇÃO BIENAL. Ciência e Humanismo. Disponível em:

http://www.bienal.org.br/FBSP/pt/AHWS/blog/post.aspx?post=111 Acesso em 25/06/2013.

FUNDAÇÃO BIENAL. Bienal a Bienal.

Disponível em:

http:/www.bienal.org.br/FBSP/pt/AHWS/BienalaBienal/Paginas/6BienalSaoPaulo.aspx?selected $=6$ Acesso em $15 / 04 / 2013$.

GALERIA LUCIANA BRITO. Artistas: Waldemar Cordeiro. Disponível em:

http://www.lucianabritogaleria.com.br Acesso em 05/06/2013.

ITAÚ CULTURAL. Enciclopédia de Artes Visuais Itaú Cultural. Disponível em: www.itaucultural.org.br Acesso em 02/Fev/2013.

ITAÚ CULTURAL. Enciclopédia Itaú Cultural de Arte e Tecnologia. Disponível em: http://www.cibercultura.org.br Acesso em 20/Mai/2013.

LEE, Sorence. Oswald Síren. In Dictionary of Art Historians. Disponível em: http://www.dictionaryofarthistorians.org/sireno.htm Acesso em 07/05/2013.

MORA, José Ferrater. Dicionario de Filosofía. Buenos Aires: Editorial Sudamericana, 1951.

MOMA. Mira Schendel, MoMA Multimedia. Disponível em:

http://www.moma.org/explore/multimedia/audios/152/1644 Acesso em: 20/05/2013.

PREFEITURA DE SÃO PAULO. História da Biblioteca Mário de Andrade. Disponível em: http:/www.prefeitura.sp.gov.br/cidade/secretarias/cultura/bmahistorico/index.php?p=7653 Acesso em: 01/02/2013.

PIRATININGA.ORG - História, Arquitetura, Paisagem de São Paulo. Disponível em http://www.piratininga.org/predios-destruidos/predios-destruidos.htm (Acessado em 23/11/12) 


\section{Anexos}

\section{Anexo A - Currículo Artístico de Mario Schenberg ${ }^{504}$}

Tive um interesse permanente pela arte desde os oito anos de idade, quando visitei pela primeira vez a Europa com meus pais.

Iniciei os meus estudos sobre História da Arte em 1938, durante a minha segunda viagem a Europa. Nessa ocasião visitei numerosos museus catedrais e palácios na Itália, Suíça, França, Bélgica e Portugal. Em 1939 conheci em Paris os pintores Emiliano di Cavalcanti e Noemi Mourão. Nessa época iniciei também meus estudos sobre História do Cinema em Paris, onde conheci Plínio Sussekind Rocha e Paulo Emílio de Salles Gomes.

De volta ao Brasil em 1939, passei a freqüentar a residência de Oswald de Andrade, onde conheci o pintor José Oswald de Andrade e escultora e desenhista Teresa d'Amico. No fim de 1940 viajei para os Estados Unidos, onde trabalhei dois anos como Fellow da John Simon Guggenheim Memorial Foundation em Astrofísica. Nesse período pude aprofundar os meus conhecimentos sobre Artes Plásticas, Fotografia e Cinema visitando numerosos Museus de Arte em New York, Washington, Baltimore, Philadelphia e Chicago. Nos Estados Unidos iniciei meus estudos sobre a Arte do Extremo Oriente e sua Filosofia.

Nos Estados Unidos fiz trabalhos artísticos de fotografia, tendo feito uma exposição no Observatório de Yerkes (Universidade de Chicago). O trabalho em fotografia me permitiu uma compreensão mais profunda dos problemas da arte. Nos Estados Unidos entrei em contato com alguns artistas importantes com Zadkine e Tamayo, aos quais fui apresentado por Teresa d'Amico em New York.

De volta ao Brasil em 1942, fui apresentado por Bruno Giorgi a Alfredo Volpi, de quem me tornei amigo íntimo até hoje. Minha atividade de crítico de arte foi iniciada com a organização da primeira exposição individual de Volpi, para a qual escrevi o texto do catálogo, além de ter tirado as fotografias das telas.

Bruno Giorgi e Alfredo Volpi me apresentaram aos artistas do Grupo Santa Helena, com os quais estabeleci sólidas relações de amizade. Conheci também José Pancetti, do qual me tornei também amigo íntimo até o fim de sua vida.

Depois da volta dos Estados Unidos, freqüentei também o atelier de Lasar Segal, que já conhecia desde 1940. Freqüentei também o atelier de Flávio de Carvalho. Posteriormente

${ }^{504}$ Centro Mario Schenberg de Documentação da Pesquisa em Arte - ECA USP. 
tornei-me amigo de Cândido Portinari, cujos murais já conhecera nos Estados Unidos. Convivi muito com Portinari em Paris depois de 1948. Nessa época conheci também pessoalmente numerosos artistas europeus, entre os quais Picasso, Chagall e Gutuso, além dos brasileiros Mario Gruber, Carlos Scilar e Antônio Bandeira.

No período entre 1942 e 1948 escrevi sobre Volpi, Pancetti, Bruno Giorgi e Figueira, sem exercer sistematicamente a crítica de arte. Comecei, porém a me relacionar com a crítica de arte paulistana, tornando-me amigo de Lourival Gomes Machado, Sérgio Milliet, Maria Eugenia Franco, Ciro Mendes, além de Paulo Mendes de Almeida, Osório César e Jorge Amado que já conhecera anteriormente.

De 1948 até 1953 permaneci na Europa. Nesses anos ampliei muito o meu conhecimento da arte européia, nas viagens que fiz pelos países da Europa Ocidental, Central e Oriental. As viagens pela Inglaterra, Holanda, Dinamarca, Alemanha, Aústria, Polônia, Checoslovaquia, Suíça, França e Itália, me permitiram conhecer melhor várias épocas da Arte Européia, assim como da Arte Africana e Asiática, pelas obras dessas regiões expostas em museus da Europa.

De 1953 a 1958 fiquei afastado de atividades artísticas e críticas limitando-me a visitar as Bienais de São Paulo e a fazer algumas leituras sobre as movimentos da arte contemporânea. A partir de 1958, aprofundei os meus contactos com o movimento artístico participando de debates sobre a pintura de Volpi em São Paulo e no Rio de Janeiro, estimulado por Mario Pedrosa, Waldemar Cordeiro e Theon Spanudis. Intensifiquei então os meus contatos com os artistas concretistas de São Paulo e com os neo-concretistas do Rio de Janeiro que conheci na exposição de Volpi do Museu de Arte Moderna de lá.

Em 1961 fui encarregado por Mário Pedrosa de organizar a Retrospectiva de Volpi na Bienal e de escrever o texto correspondente, por me considerar como a pessoa com melhor conhecimento da obra de Volpi e de haver reconhecido primeiro a sua estatura artística excepcional. A partir dessa Retrospectiva Volpi passou a ser considerado como uma das personalidades máximas da Arte Brasileira.

Participei das Bienais de 1965, 1967 e 1969 como representante dos artistas no Júri Nacional de Seleção. Participei do Júri da $1^{\text {a }}$ Bienal Nacional da Bahia em 1966 e dos júris de vários Salões em São Paulo e Minas Gerais, assim como do Júri do $1^{\circ}$ Salão da Bússola no Rio de Janeiro, em 1969. Desde então, participei apenas de alguns júris de Salões de cidades paulistanas até 1974 .

Nas décadas de sessenta e setenta escrevi numerosas apresentações de artistas renomados como Volpi, Mario Gruber, Mira Schendel, Waldemar Cordeiro, Rubem 
Gerchman, Antonio Dias, Roberto Magalhães, Hélio Oiticica, José Roberto Aguilar, Arnaldo Ferrari, Cláudio Tozzi, Frederico de Morais, Roberto Mariconi, Antônio Marx, Teresa d'Amico, Ivald Granato, Érika Steinberger, Jenner Augusto, Sônia Castro, Waldomiro de Deus, Moby, Niobe Xandó, Ricardo Augusto Pinho, Marlene Trindade, Vera Ilse, Anésia Pacheco e Chaves, Lourdes Cedran, Kinoshita, Aluizio Siqueira, Sheila Brannigan, Bruno Giorgi, Zoravia Bettiol, Umberto Espíndola, Saverio Castellano, Sérgio Lima, João Rossi, Ely Bueno, Montez Magno, João Parisi, Alice Carracedo, Neusa d'Arcancny, Maurício Nogueira Lima e de numerosos artistas jovens.

Escrevi sobre arte em jornais de São Paulo e do Rio de Janeiro e também em revistas de arte. Sou autor do estudo "Arte e Tecnologia", incluído na obra Arte Brasileira Hoje de Ferreira Gullar, publicado em 1973 pela Editora Paz e Terra. Publiquei o estudo "Bruno Giorgi e o Paganismo" na Revista Acadêmica, nº 66, 1945, dedicado a Bruno Giorgi. Publiquei recentemente um estudo sobre os movimentos concreto e neo-concreto na Revista Arte Hoje, $\mathrm{n}^{\mathrm{o}}$ 02, 1977. Escrevi também vários estudos como textos de catálogos de exposições coletivas.

Sou membro da Associação Internacional dos Críticos de Arte e da Associação Brasileira dos Críticos de Arte. Sou membro da Academia Brasileira de Ciências e da Academia de Ciências do Estado de São Paulo e professor aposentado da USP.

Mario Schenberg 


\section{Anexo B - Autobiografia de Mario Schenberg ${ }^{505}$}

Nasci a 2 de Julho de 1914, em Recife. Em 1931 iniciei o curso na Escola de Engenharia de Pernambuco. Em 1933 transferi-me para a Escola Politécnica de São Paulo, recebendo o diploma de engenheiro eletricista em 1935.

Em 1936 concluí o curso de bacharel em matemática na Faculdade de Filosofia, Ciências e Letras da Universidade de São Paulo, na primeira turma da Faculdade. Desde 1936 trabalho na USP. Inicialmente fui preparador na cadeira de Física Geral e Experimental na Escola Politécnica e, no ano seguinte, fui nomeado assistente de Física Teórica na FFCLL. Em 1944 fiz concurso na USP para a cadeira mecânica Celeste e Superior do Departamento de Física da FFCL, que depois tornou-se o Instituto de Física.

Realizei muitas viagens ao exterior. Em 1939 parti para a Europa, tendo trabalhado no Instituto de Física da Universidade de Roma com o professor Enrico Fermi. A seguir, transferi-me para Zurique onde trabalhei com o prof. Pauli. Com a aproximação da guerra, parti para parti para Paris onde fiquei trabalhando com o prof. Frederic Joliot Curie.

Em 1940, já de volta ao Brasil, ganhei uma bolsa da Fundação Guggenheim e trabalhei com o Prof. G. Gamow em Washington, realizando investigações em Astrofísica. Depois, fui membro do Institute for Advanced Studies de Princeton. Trabalhei ainda no Observatório Astronômico de Yerkes com o prof. Schanndrasekar. Voltei em 1944 para o Brasil, para prestar concurso na USP. Permaneci no Brasil até 1948 quando parti para a Europa, ficando 5 anos em Bruxelas, trabalhando em raios cósmicos e mecânica estatística; trabalhei também com o prof. Prigogine, com o prof. Cosnyns e colaborei com o grupo de Prof. Occhiialini.

Em 1953, tornei-me diretor do Departamento de Física da USP. Permaneci neste cargo até 1961. Durante este período, criei o Laboratório de Estado Sólido e instalei o primeiro computador, criando assim os cursos de computação da USP. Ao longo de todos esses anos publiquei mais de uma centena de trabalhos em Física Teórica, Física Experimental, Astrofísica, Mecânica Estatística, Mecânica Estatística, Mecânica Quântica, Relatividade, Teoria Quântica do Campo, fundamentos de Física, além de escrever muitos trabalhos em Matemática.

${ }^{505}$ Centro Mario Schenberg de Documentação da Pesquisa em Arte - ECA?USP. 
Participei ativamente da discussão dos problemas político-econômicos do Brasil. Inicie em São Paulo a campanha O Petróleo é Nosso; lutei pela defesa de nossos recursos de minérios nucleares, e estou envolvido nos debates sobre as centrais nucleares.

Nos últimos anos tenho me dedicado com muito interesse a trabalhos de História da Ciência. Estive sempre interessado pelos problemas da Educação. Participei da realização da Bienal de São Paulo e escrevi muitos ensaios sobre arte.

Mario Schenberg

Década de 1980 


\section{Anexo C - Mira Schendel: breve biografia 506}

Myrrha Dagmar Dub (Zurique, Suíça 1919 - São Paulo SP 1988). Desenhista, pintora, escultora. Muda-se para Milão, Itália, na década de 1930, onde estuda arte e filosofia. Abandona os estudos durante a Segunda Guerra Mundial (1939-1945). Estabelece-se em Roma em 1946, e, em 1949, obtém permissão para mudar-se para o Brasil. Fixa residência em Porto Alegre, onde trabalha com design gráfico, faz pintura, escultura de cerâmica, poemas e restauro de imagens barrocas, assinando com seu nome de casada Mirra Hargesheimer. Sua participação na $1^{\text {a }}$ Bienal Internacional de São Paulo, em 1951, permite contato com experiências internacionais e a inserção na cena nacional. Dois anos depois muda-se para São Paulo e adota o sobrenome Schendel. Na década de 1960 realiza desenhos em papel de arroz. Em 1966, cria a série Droguinhas, elaborada com papel de arroz retorcido e trançado, que é apresentada em Londres, na Galeria Signals, por indicação do crítico de arte Guy Brett (1942). Nesse ano, passa por Milão, Veneza, Lisboa e Sttutgart. Conhece o filósofo e semiólogo Max Bense (1910 - 1990), que contribui para a realização de sua exposição em Nurembergue, Alemanha, e é autor do texto do catálogo. Em 1968 começa a produzir obras utilizando o acrílico, como Objetos Gráficos e Toquinhos. Entre 1970 e 1971, realiza um conjunto de 150 cadernos, desdobrados em várias séries. Na década de 1980, produz as têmperas brancas e negras, os Sarrafos e inicia uma série de quadros com pó de tijolo. Após sua morte, muitas exposições apresentam sua obra dentro e fora do Brasil e, em 1994, a 22 Bienal Internacional de São Paulo lhe dedica uma sala especial. Em 1997, o marchand Paulo Figueiredo doa grande número de obras da artista ao Museu de Arte Moderna de São Paulo $\mathrm{MAM} / \mathrm{SP}$.

Atualizado em 10/12/2010.

${ }^{506}$ ITAÚ CULTURAL. Enciclopédia de Artes Visuais Itaú Cultural. Disponível em: $\underline{\text { www.itaucultural.org.br }}$ Acesso em 09/Jul/2013. 


\section{Anexo D - Lygia Clark: breve biografia ${ }^{507}$}

Lygia Pimentel Lins (Belo Horizonte MG 1920 - Rio de Janeiro RJ 1988). Pintora, escultora. Muda-se para o Rio de Janeiro, em 1947, e inicia aprendizado artístico com Burle Marx (1909-1994). Entre 1950 e 1952, vive em Paris, onde estuda com Fernand Léger (18811955), Arpad Szenes (1897-1985) e Isaac Dobrinsky (1891-1973). De volta para o Brasil, integra o Grupo Frente, liderado por Ivan Serpa (1923-1973). É uma das fundadoras do Grupo Neoconcreto e participa da sua primeira exposição, em 1959. Gradualmente, troca a pintura pela experiência com objetos tridimensionais. Realiza proposições participacionais como a série Bichos, de 1960, construções metálicas geométricas que se articulam por meio de dobradiças e requerem a co-participação do espectador. Nesse ano, leciona artes plásticas no Instituto Nacional de Educação dos Surdos. Dedica-se à exploração sensorial em trabalhos como A Casa É o Corpo, de 1968. Participa das exposições Opinião 66 e Nova Objetividade Brasileira, no Museu de Arte Moderna do Rio de Janeiro (MAM/RJ). Reside em Paris entre 1970 e 1976, período em que leciona na Faculté d'Arts Plastiques St. Charles, na Sorbonne. Nesse período sua atividade se afasta da produção de objetos estéticos e volta-se sobretudo para experiências corporais em que materiais quaisquer estabelecem relação entre os participantes. Retorna para o Brasil em 1976; dedica-se ao estudo das possibilidades terapêuticas da arte sensorial e dos objetos relacionais. Sua prática fará que no final da vida a artista considere seu trabalho definitivamente alheio à arte e próximo à psicanálise. A partir dos anos 1980 sua obra ganha reconhecimento internacional com retrospectivas em várias capitais internacionais e em mostras antológicas da arte internacional do pós-guerra.

Atualizado em 31/05/2011

${ }^{507}$ ITAÚ CULTURAL. Enciclopédia de Artes Visuais Itaú Cultural. Disponível em: $\underline{\text { www.itaucultural.org.br }}$ Acesso em 09/Jul/2013. 


\section{Anexo E - Maurício Nogueira Lima: breve biografia 508}

Maurício Nogueira Lima (Recife PE 1930 - Campinas SP 1999). Pintor, arquiteto, desenhista, artista gráfico, professor. Aos dois anos de idade, muda-se com a família para São Paulo. Entre 1947 e 1950, estuda artes plásticas no Instituto de Belas Artes da Universidade Federal do Rio Grande do Sul - UFRGS, em Porto Alegre. De volta a São Paulo, em 1951, freqüenta cursos de comunicação visual, desenho industrial e propaganda no Instituto de Arte Contemporânea do Museu de Arte de São Paulo Assis Chateaubriand - Masp, onde conhece Alexandre Wollner (1928), Antônio Maluf (1926 - 2005) e Leopoldo Haar (1910 1954). A convite de Waldemar Cordeiro (1925 - 1973) integra, em 1953, o Grupo Ruptura e participa de diversas mostras de arte concreta nos anos que se seguem. Estuda arquitetura na Universidade Presbiteriana Mackenzie, em São Paulo, entre 1953 e 1957. Em 1958, é responsável pela criação da logomarca e programação visual da $1^{\text {a }}$ Feira Internacional da Indústria Têxtil - Fenit, em São Paulo e, em 1960, realiza as primeiras grandes instalações ambientais para indústrias automobilísticas no Salão do Automóvel. A partir de 1974, leciona, entre outras escolas, na Faculdade de Arquitetura e Urbanismo da Universidade de São Paulo - FAU/USP, onde conclui mestrado e doutorado na área de estruturas ambientais urbanas. Nas

décadas de 1980 e 1990, realiza diversos trabalhos em espaços públicos, como a praça Roosevelt, largo São Bento, estações de metrô e no elevado Costa e Silva, todos em São Paulo.

Atualizado em 03/01/2007

\footnotetext{
${ }^{508}$ ITAÚ CULTURAL. Enciclopédia de Artes Visuais Itaú Cultural. Disponível em: www.itaucultural.org.br
} Acesso em 09/Jul/2013. 
Anexo F - Bienais de São Paulo: imagens Arquivo Histórico Wanda Svevo/

\section{Fundação Bienal}

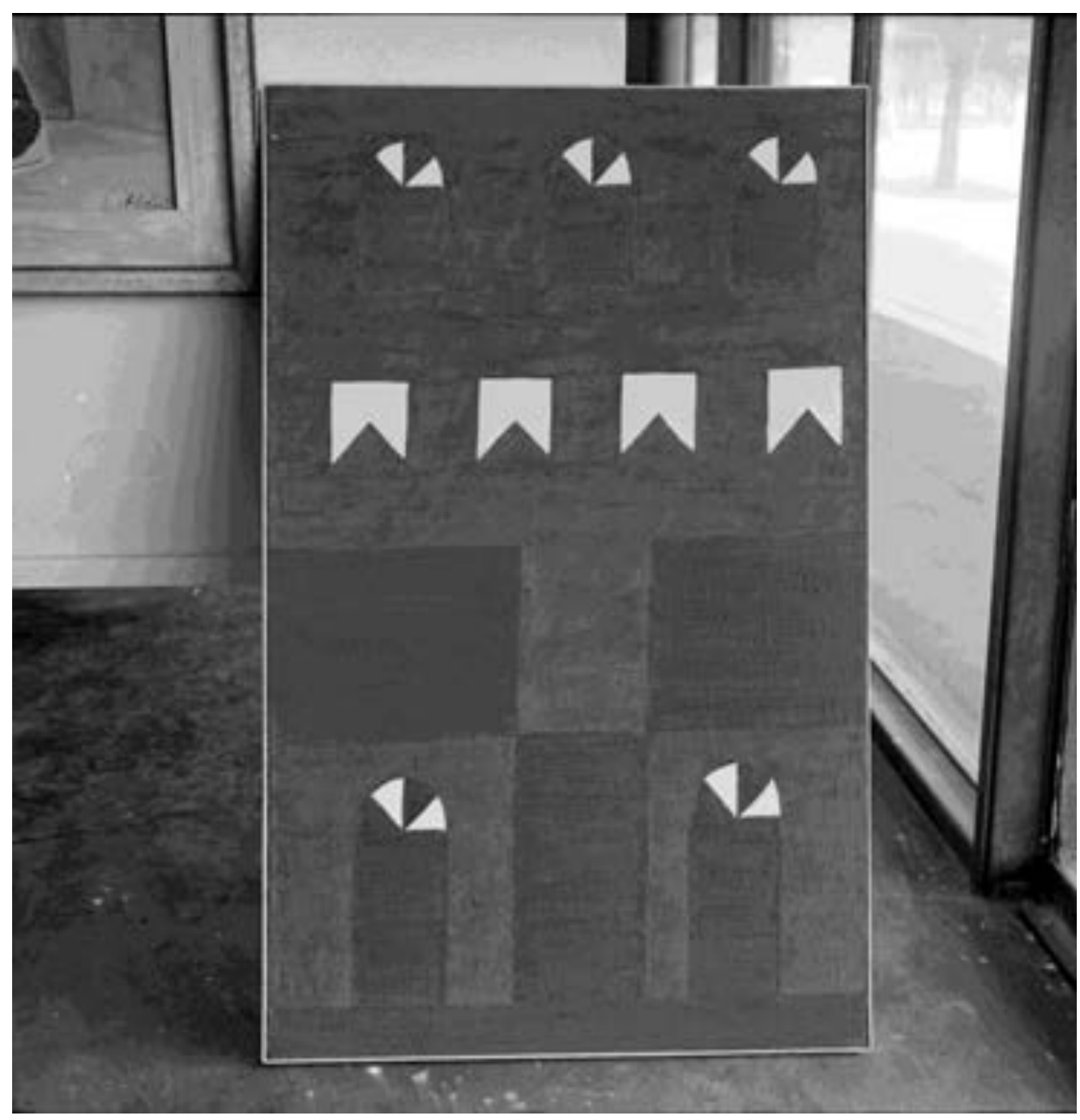

Figura 43 - VI Bienal de São Paulo. Reproduções de quadros de Alfredo Volpi. Autoria desconhecida, Arquivo Histórico Wanda Svevo/Fundação Bienal.

A tela foi identificada, trata-se de Fachada com Bandeiras, 1959, Têmpera sobre tela, 116 x $72 \mathrm{~cm}$. Acervo do Museu de Arte de São Paulo - MASP, doação de Ernest Wolf. 


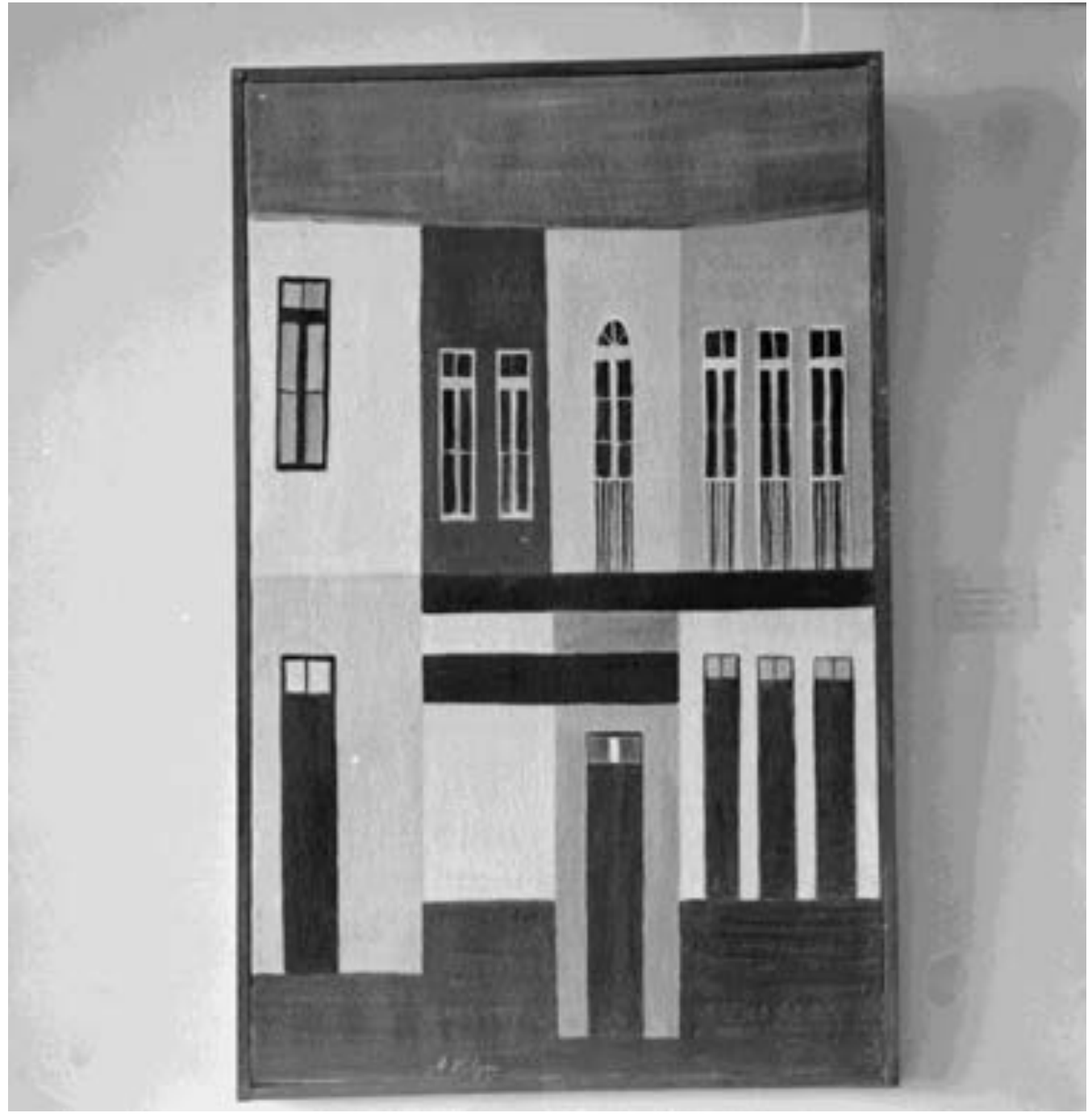

Figura 44 -VI Bienal de São Paulo. Reproduções de quadros de Alfredo Volpi. Autoria desconhecida, Arquivo Histórico Wanda Svevo/Fundação Bienal. 


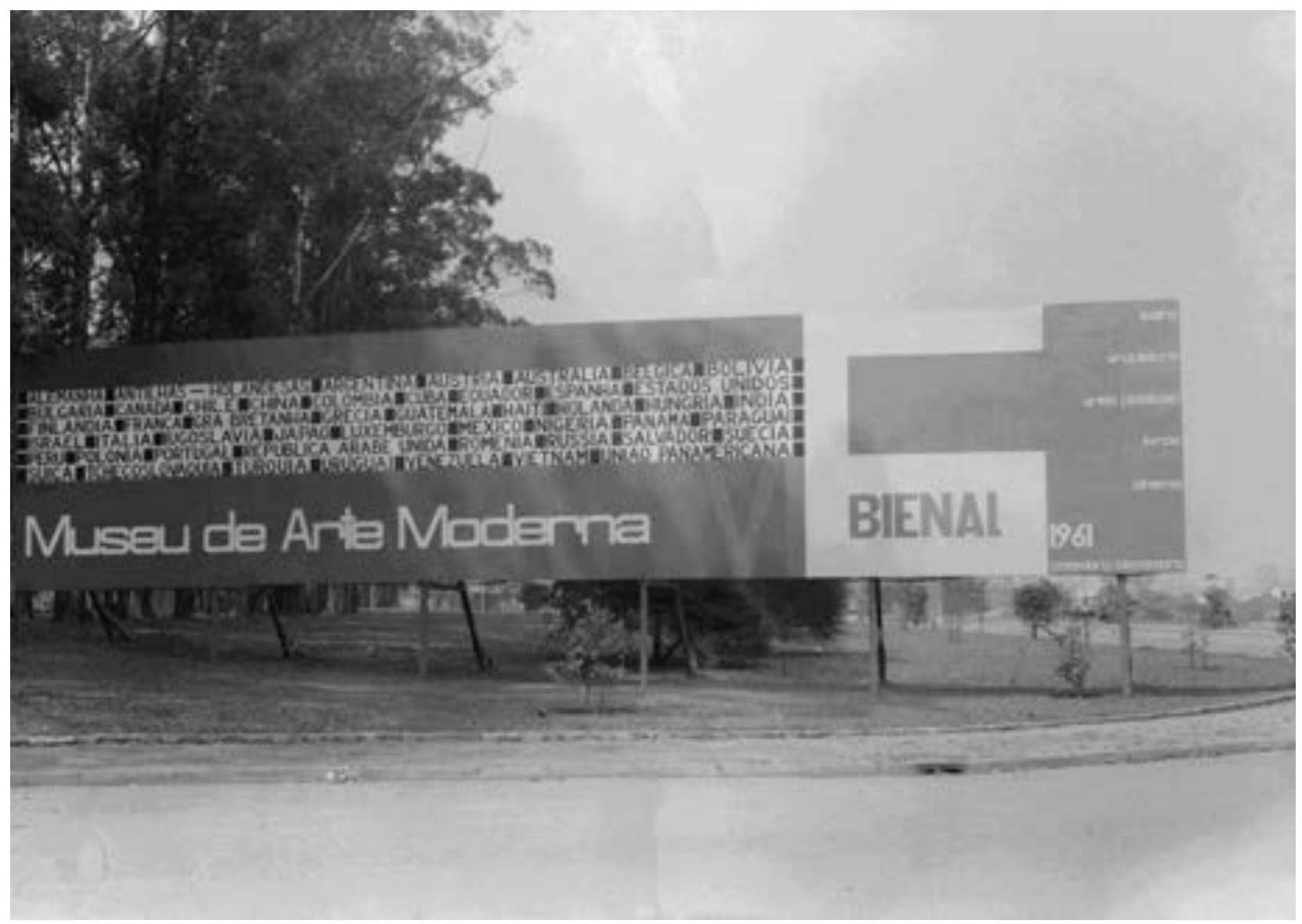

Figura 45 -Vista externa com outdoor da VI Bienal de São Paulo. Autoria desconhecida, Arquivo Histórico Wanda Svevo/Fundação Bienal. 


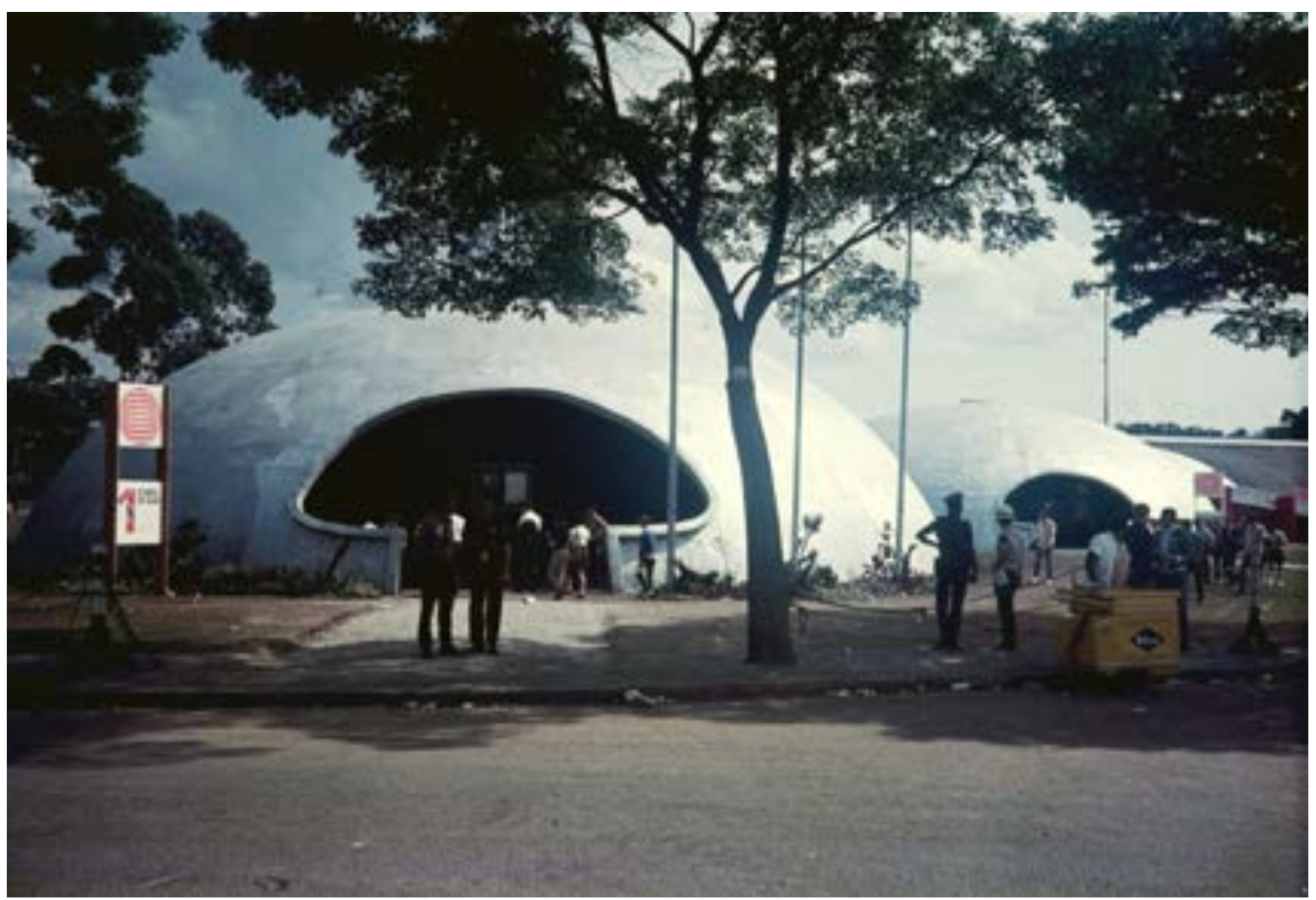

Figura 46 -X Bienal de São Paulo, vista externa.. Estruturas temporárias, em forma de oca, construídas para abrigar os eventos da II Bienal de Ciência e Humanismo. Autoria desconhecida, Arquivo Histórico Wanda Svevo/Fundação Bienal. 
MAL-10211

São Paulo,2 de fevereiro de 1961

I1mo. Senhor

Prof. Mario Sohemberg

Rus São Vioente de Paula,501

a a 1 te 1

Meu velho andgo,

Ap6s nosaa sonvorsa telefonica de ontem Iiques eontente ell abber que a rotrospeotiva do Volpl nexá confiads a v. em Iugar do Bjanudia que viajará brovorterite.

Agors 2100 aguardando seu comparecinento pera tragarmos o plano dofinitivo da exposigão.

Saน,

Jario Pedrosa

Diretor Geral 


\section{Anexo H - Manifesto dos $4^{509}$}

Senhor presidente da república: artistas, críticos, intelectuais brasileiros e participantes desta grande iniciativa cultural, hoje de âmbito internacional que é a Bienal de São Paulo, congratulam-se com a presença de $\mathrm{V}$. Ex. ${ }^{\mathrm{a}}$ aqui neste recinto e pede vênia para fazer o seguinte apelo: Sustar, por sua apropriada intervenção, a efetivação da prisão preventiva que acaba de ser decretada pela Auditoria Militar de São Paulo contra o professor Mario Schenberg, depois de ter o STM [Superior Tribunal Militar] ter considerado insubsistente por falta de fundamento jurídico a acusação que contra ele foi levantada, bem como contra seus colegas universitários, professores Fernando Henrique Cardoso, João da Cruz Costa e Florestan Fernandes.

O professor Mário Schenberg, além de físico de renome mundial, tem parte ativa na vida artística do Brasil como um dos seus críticos mais eminentes, tendo participação no júri de seleção desta Bienal.

Os abaixo assinados cumprimentam respeitosamente o presidente da República (seguem as assinaturas de todos os artistas brasileiros na Bienal).

${ }^{509}$ Castelo inaugura a Bienal dizendo que a arte serve à paz. Jornal do Brasil (Estado da Guanabara), 05/09/1965. 
Ilmo. Sr.

Prancisco Matarazzo Sobrinho

Presidente da Fundação Bienal de São Paulo

Capital

Senhor Presidente:

Bm resposta à sua carta de 2 de maio de 1969, te mos o prazer de comunicar-lhe que a nossa entidade, atendendo, sol $\underline{\underline{f}}$ cita, so pedido da Fundação Bienal, promoveu eleições livres em São Paulo e no Rio para indicação de um membro do Júri de Seleção, convocando todos os artistas interessados, mesmo aquêles que não per tencem aos seus quadros sociais. Infelizmente não estamos aparelhados para promover elelções em outras cidades brasileiras. O resulta do, portanto, não tem valor nacional. Prevendo êsse fato é que, através do nosso representante na Assessoria, por ocasião da elabora ção do regulamento, defendemos o critério de eleição direta promovi da pela Blenal. Da nossa consulta, resultou como o mais votado o of tico de arte Mário Schenberg.

Na carta de $\mathrm{V}$. Sa. é requerida a nossa opinião a respeito de "palestras informais" que sugerem restrições anônimas ao critério misto de convite e seleção adotado pela Assessoria de Ax tes Plásticas para a próxima Bienal. Trata-se de assunto que afeta exclusivamente a Assessoria. O nosso ponto de vista já foi exposto por ocasião dos debates. A êsse respeito, cumpre informar que aAIAP pautou a sua conduta em pesquisa de opinião realizada simultâneamen te no Rio e em São Paulo que reuniu mais de cen depoimentos, constí tuindo,portanto, amostragem válida. Várias Assembléias extraordinárias, também foram convocadas especialmente para proporcionar a todos os artistas oportunidade de exprimir opintões pessoais sôbre os problemas do nosso relacionamento con a Pundação Bienal e sôbre aspectos técnicos oriundos đêsse relacionamento. Todos os artistas, as sim a desejando, oportunidade de manifestar-se, trocando idéias com os colegas. Nesse sentido, a AIAP limitou-se tão sòmente a desempenhar o papel de canel de ralacionamento entre os artistas e a Diretoria da Fundação Bienal de São Paulo.

No entanto, se fôr intenção da Direção Adminis trativa da Bienal reabrir o debate a respeito do Regulamento da $X$ Bienal, então sugerimos que o mesmo seja mais profundo, abrangendo 
aspectos que consideramos culturalmente anacrônicos, principalmente a manutenção de prêmios opulentos, conferidos por um júri interna cional, cuja origem continua desconhecida.

De outro lado, levantar suspeltas à probidade de un júri que ainda não existe, acusando-o a priori de "favoritismo", significa oriar dúvidas injustificadas a respelto do oritério de eg colha a ser adotado pela Diretoria da Fundação, que, contra o nosso voto, nomeia três, (a maioria absoluta) dos cinco menbros.

Finalizando, tendo em vista 0 aperfeiçoamento dos mecanismos da própria Bienal, sugerimos que os assuntos técnicos se jam abordados sòmente através da Assessoria de Artes Plásticas, è qual caberá também a tarefa de organizar o debate através do seminá rio proposto pelas entidades que congregam oríticos e artistas e aprovado em princípio por $\mathrm{V}$. Sa.

Esperando que a colaboração da nossa entidade can a Fundação Bienal dê resultados realmente positivos, para o futuro da arte moderns, enviamos-ine os votos da nossa mais al ta estima e consideração.

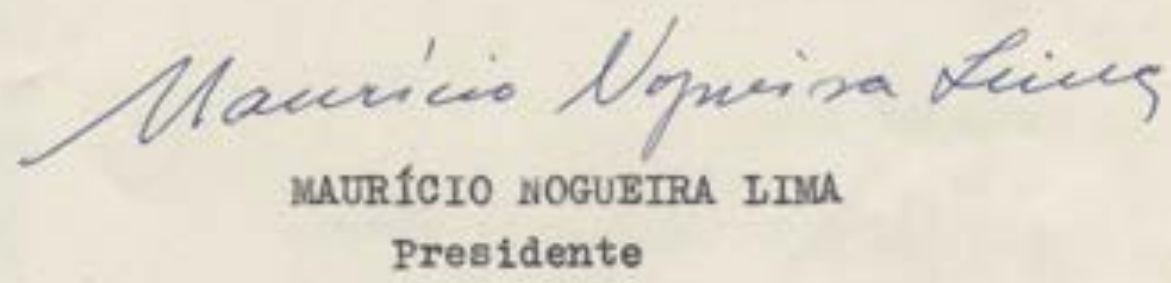

PS - A fin de informar os associados, reservamo-nos o direito de divulgar a presente carta.

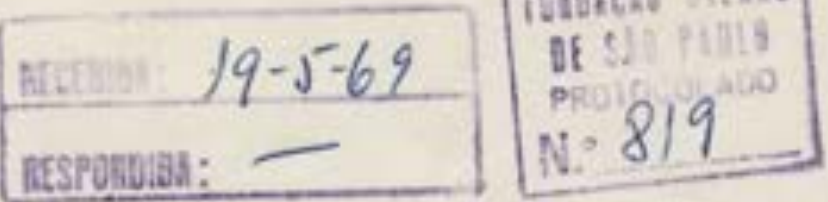




\section{ATA DA $1=$ REUNIÃO DO JURI DE SELEÇAO PARA A X BIENAL DE SÃo PAULO}

No día 27 de maío de 1969 reuniuzse, na sede da Fundação Bie nal de Säo Paulo, o Júri de Seleção para a X Bienal de Săo Päu 10. com o fim de escolher os 25 artistas brasileiros a serem convidados para a sala brasileira. O juri é formado de cinco elementos: Marc Berkowitz, indicado pela ABCA, Mario Schomberg, indicado pela AIAP, Bdyla Mangabeira Unger, Watmir Ayala e Oswaldo de Andrade Filho, indicados pela Bienal. Por sugestão da sra. Edyla Mangabefra Unger foi proposto o nome do sr. Marc Berkowitz para presidente da mesa, com o que todos concordaram. Foram feitas constderacöes gerais sobre os trabalhos da Comissão de Artes Plásticas em relacão as salas es pecials da secão nacional. Em eeguida, o júri de selecão passou a elaborar a celagão dos 25 artistas a serem convidados para a sala do Brasil. Os convites foram feitos da seguinte forma: ca da elemento do jári apresentou uma lista de nomes que foram vō tados pelos membros do jári. Desta forma, foram escolhidos 25 nomes para os convites e mais 4 nomes para o caso de alguma desistencia entre os convidados. Os artistas a serem convida dos são:Joäo Camara Filho, Wiliys de Castro. Lygia Clark. Roberto De Lamonica. Antonio Dias. Hermelindo Fiaminghi. Rubens Gerchman, Gastão Manoel Henrique. Tombshige Kusuno, Wesley Duke Lee, Nelson Leirner, Roberto Magalhäes, Marcelo Nitsche Helio Oitocica. Abraham Palathik, José Rezende, Ione Saldanha, Mira Schendel, Ivan Serpa, Amellia Toledo, Yutaka Toyota, Rubem Valentim, Carlos Vergara, Mary Vieira e Franz Weissmann. Os convites serão feitos por carta: para os artistas que se encontram no exterior, será enviado um telegrama. Para a eventual substituição foram escolbidos: Humberto Sprndola, Hisao Hoara, Miriam Chiaverini e Wanda Pimentel. O jári passou a trocar idélas sobre as salas especiais do Brasil e, para maiores esclarecimentos. foi chamado o sr. Wolfgans pifeiffer, mem bro da Comissão de Artes Plásticas. Não tendo sido encontrado, veio para substitui-10, o sr. Frederico Nasser, igualmente componente da Comissão. Fol então sugerido que a Comissäo de Artes Plásticas delegasse sua função de organizar as salas especiais ao Jấi de Selecão. Ficou assentado que a Comissão seria consultada a respeito.Foram entáo trocadas algumas idéias sobre a organizaça de uma sala especial de confoonto de tendôncias, uma de arte fantástica e uma de novos varores, que se rão estudadas depois de recebida a resposta da Comissă de Ar tes Plásticas. Nada mais havendo a tratar. foi encerrada a reunião. A presente ata, assinada por todos, foi redigida por mim, Lourdes Lopes. Säo Paulo, 27 de maio de 1969.

B.M.Unger

M. Schemberg

Walmir A yala

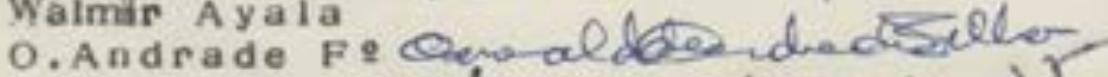

Marc Berkowitzluler
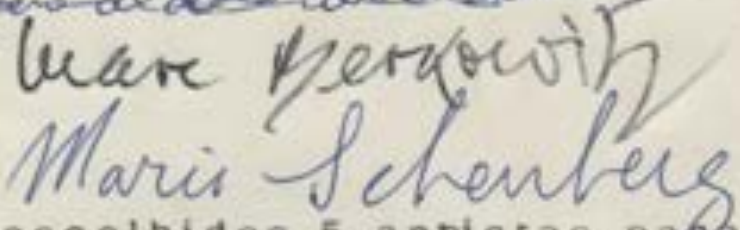

Adendo: Foram escolhidos 5 arcistas paba o caso de desistencia entre os convidados para a seçäo brasileira e náo 4, como cons ta nesta ata. O nome omitido foi o de Avatar Morais. Também, quanto ao assunto "Salas especiais", foi discutida a possibilidade de se realizar uma sala de movimento concretista e neoconcretista. 


\title{
Anexo K - Histórico do Centro Mario Schenberg de Dcumentação da pesquisa em Arte - ECA/USP
}

\author{
DOAÇÃO DO ARQUIVO SCHENBERG ${ }^{510}$
}

O Arquivo Schenberg foi doado à Associação dos Pesquisadores em Artes - ABPA, durante a homenagem feita ao professor Mario Schenberg pelos pesquisadores desta Associação, por ocasião do I Congresso Nacional da ABPA, no Conselho Universitário da Universidade de São Paulo, em 1988.

O acervo é constituído de hemeroteca, dos livros de arte do próprio Schenberg, dos catálogos de exposições que assinou, de periódicos e, principalmente, de cerca de quatrocentos e quinze originais das críticas de arte do professor (sendo que grande parte corresponde ao período de 1963 e 1987, com 32 títulos referentes a movimentos e grupos artísticos), cujo valor histórico deve ser preservado.

Contém ainda manuscritos, cartas, recortes de periódicos, fotografias e discos. Com a organização desse material, torna-se possível aquilatar o pensamento estético de Mario Schenberg. Com o desdobramento dessa proposta vêm sendo realizadas várias pesquisas e atividades no Centro Mario Schenberg de Documentação da Pesquisa em Artes - ECA/USP.

\footnotetext{
${ }^{510}$ Centro Mario Schenberg de Documentação da Pesquisa em Artes - ECA/USP
} 